UNIVERSIDADE DE SÃO PAULO

FACULDADE DE FILOSOFIA, LETRAS E GIÊNGIAS HUMANAS

DEPARTAMENTO DE LETRAS GLÁSSICAS E VERNÁGULAS

PROGRAMA DE PÓS-GRADUAÇÃO EM LETRAS CLÁSSICAS

RICARDO DA GUNHA LIMA

\title{
A presença clássica na poesia neolatina do humanista português Antônio de Gouveia
}

\begin{abstract}
Tese apresentada ao Departamento de Letras Clássicas e Vernáculas (DLGV), da Faculdade de Filosofia, Letras e Ciências Humanas (FFLCH), da Universidade de São Paulo (USP), como exigência parcial para a obtenção do título de Doutor em Letras Clássicas.
\end{abstract}

Orientador: $\operatorname{Prof}^{\mathrm{a}} \operatorname{Dr}^{\mathrm{a}}$ Zélia Ladeira Veras de Almeida Cardoso

São Paulo

agosto de 2007 


\section{agradecimentos}

À professora Zélia Ladeira Veras de Almeida Cardoso, notável orientadora, profunda conhecedora de língua e literatura, perfeita na combinação de estímulo e exigência,

Ao professor Carlos Antonio Kalil Tannus, orientador inicial da pesquisa, mestre erudito e incomparável, que me abriu as vias de acesso ao Humanismo em Portugal,

Ao professor Sebastião Tavares de Pinho, supervisor do estágio em Portugal, magnânimo em sua cordialidade, solicitude e apurado conhecimento,

Ao professor Paulo Martins, membro das bancas de qualificação e de julgamento final da tese, admirável pelo caráter solidário e pela inteligência refinada,

À professora Elaine Cristine Sartorelli, membro do júri final da tese, esmerada estudiosa do século XVI e amiga de todas as horas;

Ao professor João Angelo Oliva Neto, membro da banca de qualificação, tradutor insuperável, que contribuiu com observações argutas no aprimoramento da pesquisa;

Ao professor Marcelo Vieira Fernandes e a todos os meus colegas de docência da Área de Língua e Literatura Latina da Universidade de São Paulo, amigos que, com zelo e consideração, engrandeceram consideravelmente minha pesquisa e minha vida;

Aos meus demais colegas de docência do Departamento de Letras Clássicas e Vernáculas (DLCV) da FFLCH / USP; notadamente aos amigos professores das áreas de Língua e Literatura Grega e de Literatura Portuguesa, que sempre me apoiaram;

Aos docentes e funcionários do Instituto de Estudos Clássicos da Universidade de Coimbra, que me receberam em Portugal com acolhimento inigualável;

Aos docentes e funcionários do Departamento de Letras Clássicas (DLC), do Centro de Letras e Artes (CLA) e do Fórum de Ciência e Cultura (FCG) da Universidade Federal do Rio de Janeiro (UFRJ), que, com simpatia fora do comum, colaboraram de modo especialmente atencioso no progresso de minhas atividades de estudo e pesquisa;

Aos funcionários das seguintes instituições de acervo bibliográfico e documental: Biblioteca Nacional do Rio de Janeiro; Real Gabinete Português de Leitura no Rio de Janeiro; Bibliotecas da Universidade Federal do Rio de Janeiro; Casa de Portugal em São Paulo; Bibliotecas da Universidade de São Paulo; Bibliotecas da Universidade de Coimbra; Biblioteca Nacional de Lisboa; Bibliotecas da Universidade de Lisboa; Arquivo Nacional (Torre do Tombo); Biblioteca Reale di Torino; Archivio di Stato (Torino); Archivio Storico della Città di 
Torino; Bibliotecas da Universidade de Torino; Bibliothèque Nationale de Paris, Bibliotecas da Universidade de Aix-en-Provence, British Library, entre outras, que prestaram, sempre com a maior gentileza, uma ajuda imprescindível;

À Capes, que me permitiu "prendre le chemin des écoliers", ou, no dizer renascentista, "le chemin de l'eschole”, ao conceder uma insubstituível bolsa de apoio ao estágio de pesquisa no exterior (bolsa-sanduíche), usufruída na Universidade de Coimbra;

À Pró-Reitoria de Pós-Graduação (PRPG) da Universidade de São Paulo (USP), na pessoa da Profa. Dra. Suely Vilela, na ocasião Pró-Reitora de Pós-Graduação, e a todos os seus funcionários, que me ajudaram, além da obrigação, na obtenção de um auxílio de estágio de pesquisa de curta duração, em Portugal;

Aos funcionários da Seção de Pós-Graduação da FFLCH, que acolheram minhas solicitações sempre com atenção e presteza;

Aos funcionários do Departamento de Letras Clássicas e Vernáculas (DLCV), que cotidianamente se mostram dispostos a ajudar e prestativos na solução de problemas;

Aos funcionários da Pensão Residencial Avenida, de Coimbra, e aos amigos mensalistas da mesma Residencial, que compartilharam comigo as angústias e as vitórias da pesquisa em Portugal;

Aos meus alunos da USP, que sempre me estimularam a prosseguir nesta carreira;

Aos meus antigos professores de latim da Unicamp, que, com seu encanto magistral, me encaminharam definitivamente na direção dos estudos clássicos;

Aos meus amigos pessoais e aos meus parentes e familiares, que me cercaram de carinho, paciência e força enquanto eu entregava ao desempenho de minhas funções e ao cumprimento das atividades de pesquisa;

A todos, meu sincero e eterno agradecimento por criarem as condições que me permitiram realizar esta pesquisa e este sonho. 


\section{resumo}

Esta tese trata da obra poética neolatina publicada em Lyon, França, nos anos de I539 e I540, pelo humanista português Antônio de Gouveia, consistindo em duas centenas de epigramas e mais quatro cartas de amor em versos. Foram feitos o estabelecimento do texto latino, com o cotejo de diferentes edições, e a tradução para o português, acrescida de notas e comentários. Foram feitas diversas análises, de cunho poético, para examinar os procedimentos estilísticos de composição da obra e para verificar a presença da literatura clássica no texto renascentista. A existência de duas diferentes edições da poesia epigramática propiciou o exame e a interpretação de algumas das alterações introduzidas pelo poeta lusitano. Inclui-se, ainda, um capítulo sobre a vida de Antônio de Gouveia, enfocando, principalmente, sua formação humanística e sua circulação nos meios artísticos e acadêmicos da Renascença européia.

\section{palavras-chave}

Literatura Latina e Neolatina

Língua Latina (Tradução)

Humanismo e Renascimento em Portugal

Epigrama

Carta Poética

Poesia Elegíaca 


\section{abstract}

This thesis deals with the Neo-Latin poetic work published by Antônio de Gouveia, Portuguese humanist, in Lyon, France, in the years I539 and I540, consisting of two hundred epigrams and four love letters in verse. The thesis includes the comparative edition of the Latin text, with critical apparatus, and the translation of it into Portuguese, with notes and comments. It also includes a poetic analysis, in order to examine the stylistic procedures of the composition of the work, and to verify the influence of classical literature on this Renaissance text. The existence of two different editions of the epigrammatic poetry permitted the examination and interpretation of some changes made by the Portuguese poet. The thesis also has a chapter about the life of Antônio de Gouveia, focusing his humanistic education and his movement in the artistic and academic circles of European Renaissance.

\section{keywords}

Latin and Neo-Latin Literature

Latin Language (Translation)

Humanism and Renaissance in Portugal

Epigram

Poetic Epistle

Elegiac Poetry 
A presença clássica na poesia neolatina

do humanista português Antônio de Gouveia 
«A tal ponto toda a minha jornada de trabalho é consumida pelas aulas, que o tempo que me resta para escrever é praticamente nulo. Por isso, estes meus textos que hoje se lêem, incultos, mal-acabados, parecendo recém-feitos, são palavras que foram anotadas por um aluno não inteiramente descuidado, enquanto eu ensinava e fazia uma exposição, e que, com não mais do que algumas poucas mudanças de palavras, vieram a público.

Os que pensam que é possível perfazer a contento uma obra escrita, em meio a esta atividade tão desgastante e tão absorvente que é o magistério, não têm, na minha própria opinião, uma avaliação correta nem das dificuldades desta carreira nem do número de horas livres de que dispomos.» Antônio de Gouveia, Dedicatória a Michel de L'Hospital, chanceler da França, em Obras Completas de Direito Civil.

«praelectionibus adeo opera omnis nostra occupatur, ut scriptioni temporis nihil propemodum supersit. Itaque quae nostra hodie leguntur rudia, impolita, modo nascentibus similia, nobis docentibus ac uerba fundentibus ab auditore non omnino indiligente excepta, paucis modo commutatis uerbis publicum acceperunt. Qui in hac laboriosissima et occupatissima docendi assiduitate perfici aliquid scribendo posse putant, ii meo quidem iudicio, neque difficultatis rei, neque otii nostri rationes recte subductas habent.» Ad Michaelem Hospitalium Galliae Cancellarium, In legum X titulum ad Legem Falcidiam libr. XXXV DD interpretationem, Opera Iuris Ciuilis, Lyon, I56I, p. I50 
«Toma como exemplo, posteridade, para que te acauteles,

Os crimes que cometi, temerário, numa única tradução.

Aniquilei o vigor da eloqüência com uma enxurrada fria,

Coloquei vinhos excelentes em barris podres...»

Antônio de Gouveia

Para o leitor da minha tradução do famoso discurso

Em Defesa de Ctesifonte

«Crimina, quae facto temerarii admisimus uno,

Exemplo ut caueas, accipe posteritas.

Eloquii fulmen gelido restinximus amne:

Misimus in putres Caecuba uina cados...»

Antônio de Gouveia

Ad Lectorem Orationis Illius Pro Ctesiphonte

«É fácil, a qualquer um, traduzir epigramas, mas é difícil traduzir livros.»

Hugo Grotius, nos Prolegômenos à Antologia Palatina, imitando o epigrama VII, 85, de Marcial.

«facile est epigrammata cuiuis uertere, sed libros uertere difficile est.» Ex Hugonis Grotii Prolegomenis, p. viii, Anthologia Palatina 
«somente os poemas escapam do tempo»

Antônio de Gouveia

Quarta Carta Poética, v. 70

«fugiunt carmina sola diem»

Antônio de Gouveia

Epistola Quarta, v. 70 


\section{SUMÁRIO}

Introdução …………......................................................... p. 11

Parte I: O Humanismo e a presença clássica em Antônio de Gouveia

Capítulo 1: Antônio de Gouveia e o Humanismo ............. p. p. 18

Capítulo 2: A composição poética de Antônio de Gouveia …. p. 37

Capítulo 3: Critérios estilísticos das revisões textuais de Antônio de Gouveia ................................. p. p. 140

Parte II: A obra poética neolatina de Antônio de Gouveia

Capítulo 4: Edição do texto latino $\quad$ …........................ p. 163

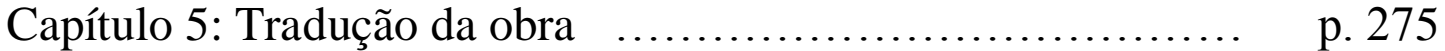

Capítulo 6: Notas e comentários $\quad$............................ p. p. 370

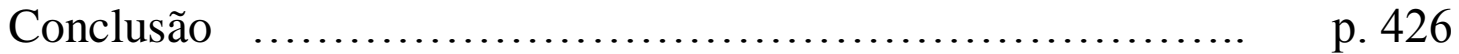

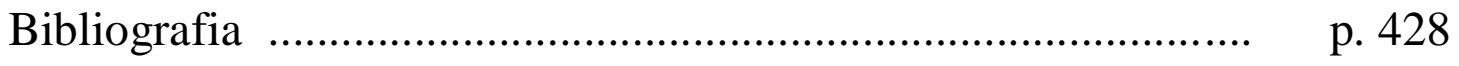




\section{INTRODUÇÃO}

O meu interesse na temática desta pesquisa provém da época em que eu estudava a obra Paradoxa Stoicorum, de Cícero, durante o curso de mestrado em Letras Clássicas, da Faculdade de Filosofia, Letras e Ciências Humanas (FFLCH), da Universidade de São Paulo.

Na ocasião, foi com surpresa que li a notícia de que a primeira tradução européia, para uma língua moderna, do texto ciceroniano, havia sido feita em Portugal, pelo humanista Duarte de Resende, da mesma família do mais conhecido Garcia de Resende, afamado por sua compilação da poesia cortês do período, cujo cancioneiro leva seu nome.

Com a curiosidade despertada por essa rara informação, fui atrás de mais dados sobre o movimento humanista em Portugal, e me deparei com um mundo muito pouco conhecido, pleno de erudição e de realizações artísticas magníficas, em pleno período da Renascença européia, vicejando em terras lusitanas, ou ainda em outras regiões, mas pelas mãos de notáveis portugueses.

Chamou especialmente minha atenção o fato de esse Humanismo de raiz classicista, oriundo da Itália, impregnado da cultura da Antigüidade greco-latina, ser quase completamente ignorado mesmo nos mais diversos ambientes acadêmicos e escolares. Muitos autores importantes e muitas obras de relevo desse período não tiveram a devida divulgação, sobretudo no caso dos textos escritos em latim.

Posteriormente, ao ingressar no doutorado, decidi eleger essa área temática para minha pesquisa, com o apoio da Profa. Dra. Zélia Ladeira Veras de Almeida Cardoso, minha orientadora, que me apresentou ao Prof. Dr. Carlos Antonio Kalil Tannus, eruditíssimo conhecedor do assunto, catedrático da Faculdade de Letras da Universidade Federal do Rio de Janeiro. O professor Tannus guiou e firmou meus primeiros passos nesse assunto tão vasto e interessante, e confirmou minha expectativa de existir um campo enorme de pesquisa científica possível na área, ainda muito pouco explorado.

Com o avanço dos estudos, optei por me concentrar na obra poética do humanista português Antônio de Gouveia, intelectual de carreira e reconhecimento internacional, que estudou e lecionou na França e morreu na Itália, a serviço da Universidade de Turim.

Sua obra literária, composta inteiramente em latim, no século XVI, havia sido pouco investigada, e, mesmo assim, de modo apenas parcial. Apesar da repercussão do nome do 
humanista na época, apesar de sua figura despertar o interesse e a dedicação de alguns dos mais afamados historiadores portugueses do século $\mathrm{XX}$, nunca havia sido feito um estudo abrangente sobre a obra poética neolatina de sua autoria, composta de epigramas e de cartas poéticas.

A escolha não poderia ter sido mais acertada. De um lado, sua produção literária é muito interessante, plena de recursos poéticos bem empregados, contendo, em meio a certa irregularidade, poemas inteligentes e versos esplêndidos, segundo uma estética marcadamente classicista. De outro lado, seu processo de criação conduz a uma abordagem extremamente profícua da literatura clássica, lançando luzes sobre as obras antigas e propiciando uma leitura renovada do cânone tradicional, em função das redes intertextuais criadas pelas práticas alusivas de Antônio de Gouveia.

Para a abordagem de tema tão instigante, planejei, inicialmente, fazer um amplo estudo acerca do movimento humanista em Portugal e das realizações artísticas ocorridas nesse país, contemplando especialmente a literatura neolatina criada por autores portugueses. Além disso, pretendia dedicar-me a uma pesquisa histórica minuciosa e conclusiva sobre a vida de Antônio de Gouveia, bem como identificar por completo as fontes textuais e os procedimentos poéticos desse autor.

Evidentemente, tais objetivos se revelaram excessivamente arrojados. Como já dizia o próprio humanista português, há quase quinhentos anos, a vida de um professor universitário, dedicado ao ensino e à pesquisa, conforme um modelo que já encontrava um adepto visionário em Gouveia, inclui compromissos que impedem a realização de planos tão extensos no tempo restrito de um curso de pós-graduação. Meus professores e minha orientadora me fizeram ver a ambição exagerada da proposta. Além disso, a banca do exame de qualificação foi muito útil e precisa ao fazer as necessárias advertências e correções relativas ao rumo da pesquisa. Mas foi sobretudo na Universidade de Coimbra, em Portugal, sob a supervisão do Prof. Dr. Sebastião Tavares de Pinho, que fui levado a reorganizar definitivamente meu projeto, ao me deparar com a riqueza e a diversidade das pesquisas efetuadas sobre esse assunto nessa instituição universitária portuguesa, ao encontrar um vasto acervo bibliográfico e, finalmente, ao conhecer com maior exatidão e profundidade a grande produção literária e artística dos humanistas portugueses, quer no solo pátrio, quer espalhados pela Europa.

Assim, sem prejudicar os pontos essenciais do plano original, deixei de lado a pretensão de fazer extensas monografias, na parte introdutória da tese, tanto a respeito do humanismo em Portugal, quanto acerca da vida de Antônio de Gouveia, e concentrei minha 
atenção na obra poética de Antônio de Gouveia e nas suas relações textuais com o patrimônio literário clássico, que já eram, na verdade, o foco do projeto de investigação. Além de propiciar maior objetividade no trabalho, essa afinação permitiu a manutenção, no corpus do estudo, de toda a obra neolatina publicada em vida pelo poeta português, abarcando as cerca de duas centenas de epigramas e os trezentos e oitenta versos de suas quatro cartas poéticas, numa somatória de poesia epigramática e elegíaca.

Além disso, como muito bem apontou a banca do exame de qualificação, um estudo minucioso sobre a vida de Gouveia, a fim de consolidar sua biografia, corria o risco de fazer associações traiçoeiras e pouco confiáveis entre informações biográficas e passagens poéticas, sem falar no risco, também mencionado naquela ocasião, de reduzir a análise da obra a uma leitura de teor biografista. Assim, tomamos a decisão de evitar as ilações incertas e as relações impalpáveis entre a vida e a obra de Antônio de Gouveia.

Apesar desses ajustes, a presente tese cumpriu uma série de objetivos propostos, representando o avanço requerido no estado de pesquisa em que se encontrava o tema em questão. Podemos citar algumas das metas alcançadas: a) foi feita a primeira edição crítica do texto poético de Antônio de Gouveia, com a organização e o estabelecimento do texto latino, a partir das publicações registradas da obra; b) foi concluída a primeira tradução integral para uma língua moderna dos volumes de poemas publicados em vida por Antônio de Gouveia, incluindo a revisão e a correção das traduções anteriores de que se tem conhecimento; em relação a esse trabalho de tradução, deve-se notar que foi empreendida a tradução inédita do conjunto de poemas publicados por Antônio de Gouveia, na cidade de Lyon, no ano de 1540, sob o título de Epigrammata; c) foi feito um levantamento das fontes citadas ou utilizadas por Gouveia, com a descoberta de alusões nunca antes apontadas, especialmente em relação aos epigramas; d) foi realizada uma análise literária de poemas e versos selecionados, examinando-se, de modo inédito, os princípios de composição poética adotados por Gouveia; e) foi apresentada uma análise comparativa das edições de 1539 e 1540 dos epigramas de Antônio de Gouveia que, embora parcial, é inédita em escala internacional.

De todas as realizações acima elencadas, gostaríamos de destacar as análises literárias da poesia gouveiana, não pelo fato de que estas tenham sido abrangentes e esgotado o corpus poético (pois, longe disso, são parciais e limitadas a alguns trechos selecionados), mas pelo fato de que elas sinalizam uma estratégia de abordagem e uma linha metodológica nunca antes empregadas no exame da obra de Antônio de Gouveia, extraídas de pesquisas recentes na área de Estudos Clássicos, privilegiando a leitura das relações intertextuais dinâmicas 
provocadas pelas alusões poéticas, e propondo uma interpretação da obra poética de Antônio de Gouveia que jamais havia sido avançada. Com efeito, por meio desse método de investigação, procuramos não apenas encontrar as fontes dos epigramas gouveianos, numa busca às vezes estéril, mas extrair, dessas fontes, interpretações e efeitos que permitam compreender com mais profundidade a poesia de Antônio de Gouveia. Dessa forma, tentamos observar, encontrar e respeitar certos elementos da composição poética gouveiana, de contornos semelhantes aos da poesia genérica clássica, que permitem o entendimento da tessitura dos poemas, numa postura inédita no que concerne a esse poeta.

Por outro lado, reconhecemos as inúmeras limitações deste trabalho, que pretendemos sanar gradualmente, ao longo dos próximos anos de investigação, a partir da experiência e das diretrizes científicas resultantes desta tese. Dentre tais limitações, podemos citar as seguintes: a) não foi concluída a edição e o levantamento de toda a obra poética de Gouveia, havendo poemas esparsos, recolhidos postumamente, que convém sejam incluídos numa futura edição das obras completas do poeta; b) não foi levada a cabo uma análise minuciosa das características estilísticas de todos os poemas; c) não foi possível encontrar alguns dos poemas que serviram de fonte ou ponto de partida de Gouveia, como no caso de poemas franceses escritos por autores renascentistas desconhecidos, que foram posteriormente vertidos para o latim pelo humanista lusitano; d) não foi possível deslindar os enigmas que cercam a vida do poeta, especialmente aqueles concernentes a uma cronologia mais exata e irrefutável de sua vida, nem foi possível identificar todas as pessoas referidas nos poemas; e) não foi possível avançar significativamente na pesquisa das relações intertextuais da poesia de Gouveia com a obra de poetas do Renascimento francês e europeu.

Todavia, essas limitações, neste momento, não representam mais que um estímulo desafiador e vibrante para a continuidade da investigação, que, nos próximos passos, pretenderá avançar no aprimoramento e na consolidação do instrumental de análise aqui apresentado, com a incorporação de todas as críticas formuladas pela banca de julgamento da tese, e na expansão das traduções, análises e investigações científicas a todo o conjunto da obra poética de Antônio de Gouveia e a todos os pontos ainda não elucidados.

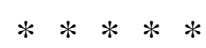

Em conseqüência das preocupações e motivações acima expostas, esta tese resultou em duas partes principais: a primeira, de caráter teórico e analítico, enfoca o processo de 
criação poética de Antônio de Gouveia e os elos textuais e contextuais que vinculam sua obra à literatura clássica greco-latina. Essa parte da tese, intitulada "O Humanismo e a presença clássica em Antônio de Gouveia", consta de três capítulos: o primeiro é uma apresentação da vida do poeta português, a qual trata primordialmente da inserção de Antônio de Gouveia no movimento humanista europeu, pois nos parece que esse aspecto colabora, efetivamente, para compreender algumas caracteristicas estilísticas da poesia gouveiana. Não deixamos, todavia, de mencionar os fatos mais conhecidos e metodicamente comprovados da vida de Gouveia, para que o leitor de sua obra possa acercar-se de um conhecimento mínimo sobre esse autor neolatino desconhecido em nossa época. Nesse intuito, servimo-nos sobretudo da extensa monografia de Joaquim Veríssimo Serrão, intitulada “António de Gouveia e o seu tempo (1510-1566)", publicada em Coimbra, em 1966, como separata do Boletim da Faculdade de Direito. Apesar de já haver completado quarenta anos, o livro do professor Serrão continua a ser o estudo mais amplo e rigoroso acerca de Gouveia.

O segundo capítulo é uma análise do estilo de composição do humanista português, buscando, numa amostragem de poemas e excertos, averiguar, notadamente, os recursos poéticos empregados e as alusões que inserem a poesia gouveiana numa rede de relações intertextuais que evoca os elementos e as obras mais tradicionais da literatura clássica. Este capítulo também se preocupou em lançar uma visão sinóptica sobre os poemas, classificando e organizando sua obra, especialmente pelo fato de que ela foi composta em gêneros poéticos clássicos diferentes, a saber, o epigrama e a elegia, cujos modelos da Antigüidade implicavam determinadas características estilísticas peculiares e uma normatização típica e pré-definida do processo de escrita que, na área de Estudos Clássicos, é denominada "composição genérica".

O terceiro capítulo estuda as alterações que o poeta lusitano introduziu na publicação de seu livro de 1540, ao revisar a reedição de 47 epigramas e de textos em prosa que acompanham o volume, em forma de prefácio e posfácio, a fim de verificarmos, por meio dessa abordagem pouco explorada, os constituintes fundamentais de sua criação poética e as preocupações estéticas que norteavam sua concepção de literatura no século XVI.

A segunda parte da tese, intitulada "A obra poética neolatina de Antônio de Gouveia", também se divide em três capítulos. O primeiro deles (e quarto capítulo da tese) traz a obra poética neolatina integral de Antônio de Gouveia, conforme a edição publicada em vida, pelo próprio autor, na cidade de Lyon, nos anos de 1539 e 1540, com o devido estabelecimento do texto latino, a partir do cotejo com edições posteriores dos poemas, e segundo os critérios 
atuais de publicação de textos latinos clássicos e neoclássicos, padronizados pelas mais importantes editoras universitárias do mundo e por instituições e associações acadêmicas. Esses critérios de edição do texto encontram-se apresentados e discutidos no início do capítulo.

O segundo capítulo contém a tradução para o português da obra poética neolatina de Antônio de Gouveia; a tradução não é metrificada, mas, apesar disso, procurou manter a correspondência de distribuição do texto, acompanhando, com mudanças de linha, as passagens de verso da poesia original; além disso, procurou respeitar, reproduzir e adaptar, na medida do possível, os recursos poéticos e os elementos estilísticos do texto original; sem a pretensão, no entanto, de realizar uma tradução poética, mas sim, em primeiro lugar, de recuperar o sentido correto do texto, especialmente por se tratar da primeira (ou, no máximo, da segunda) tradução para uma língua moderna, em todo o mundo, da poesia gouveiana. Tomamos a liberdade, neste segundo capítulo, de expor, na folha da esquerda, isto é, no verso das páginas da tese, o texto original, a fim de facilitar o exame da tradução e o cotejo com o texto latino; essas folhas trazem a mesma numeração da página à direita, isto é, o mesmo número da tradução correspondente, mas em algarismos romanos, a fím de permitir a montagem da encadernação dos exemplares da tese.

O terceiro capítulo da segunda parte apresenta notas e comentários relativos ao texto latino, reunindo informações de natureza variada, referentes ora a situações ou personalidades retratadas no texto, ora a questões de tradução, ora a aspectos da frase latina, transitando entre dados de contextualização e discussões acerca do texto em si. Não foi minha intenção, nesta tese, em momento algum, esgotar as informações pertinentes e elucidar todas as passagens dos poemas, pois esses dados serão acumulados com o passar do tempo e com o prosseguimento da pesquisa. 


\section{PARTE I}

O Humanismo e a presença clássica em Antônio de Gouveia 


\section{Capítulo I}

\section{ANTÔNIO DE GOUVEIA E O HUMANISMO}

Américo da Costa Ramalho, um dos maiores estudiosos do Renascimento em Portugal, sugere em várias de suas obras ${ }^{1}$ a adoção do ano de 1485 para marcar o início do Humanismo no país, tomando como base a data da chegada a terras lusitanas do italiano Cataldo Parísio Sículo, que fora convidado à corte portuguesa pelo rei D. João II e acabaria por levar a Portugal as idéias do movimento humanista italiano, que se caracteriza por valorizar a literatura e a cultura da época clássica. Nesse sentido, o movimento dos humanistas, eruditos que se dedicavam à leitura, edição e análise filológica de textos antigos, preconizava, por exemplo, o estudo de línguas antigas (hebraico, grego e latim), a busca de textos perdidos e a valorização de obras clássicas pouco difundidas.

Essa recuperação da literatura clássica conduziu, por sua vez, a um processo imitativo que acabou por desembocar na literatura neolatina, composta principalmente por poetas dos séculos XIV a XVI, que redigiam suas obras em latim, seguindo os modelos da Antigüidade.

Assim, embora o movimento humanista tenha alcançado Portugal tardiamente, proveniente da Itália, já se registra no final do século XV um primeiro influxo do humanismo em solo português.

Paralelamente à chegada de humanistas estrangeiros a Portugal, passa a ocorrer com maior frequiência a ida de jovens estudantes portugueses ao exterior, a fim de buscar formação universitária em escolas importantes e prestigiosas, como Salamanca, Alcalá, Florença, Lovaina e, sobretudo, Paris. Já com D. João II, e mesmo antes dele, registrava-se essa movimentação, institucionalizada por D. Manuel, primeiro rei português a criar bolsas de estudo no exterior, bancadas pelo feitor de Flandres e estabelecidas no Colégio de Montaigne, em 1498.

${ }^{1}$ Por exemplo, na série "Para a História do Humanismo em Portugal", volumes I a VI, em Estudos sobre a época do Renascimento e Estudos sobre o século XVI. 
Contudo, foi sob o reinado de D. João III que Portugal encontrou condições mais propícias para o desenvolvimento do humanismo. Esse monarca, que sucedeu a seu pai D. Manuel em 1521, caracterizou-se pelo desejo de imprimir uma marca pessoal de reestruturação da corte portuguesa e por fomentar de maneira mais intensa o enriquecimento artístico e cultural na sociedade lusitana.

Veja-se que o ano de 1521 registra também o início da guerra franco-prussiana (ou "Guerras da Itália"), em que a corte francesa enfrentou o crescente poderio de Carlos V, o pujante imperador alemão, da casa dos Habsburgos, soberano de quase meia Europa, incluindo os reinos espanhóis e dos Países Baixos. Contra ele, o rei francês Francisco I foi buscar o apoio até mesmo da Turquia.

Alheio ao conflito de dimensão continental, Portugal tentou preservar-se, procurando dedicar-se ao projeto de consolidação das conquistas auferidas pela expansão marítima. Esta já havia trazido o luxo e as riquezas a Portugal, cuja corte, sob D. Manuel, alcançara grande esplendor. Exemplo disso é a embaixada de Tristão da Cunha ao Papado. Mas o afluxo de riquezas começou a ser desbaratado pelo consumo de bens supérfluos e pelo pagamento de empréstimos, além das dificuldades próprias de um empreendimento tão vultoso, provocando o enfraquecimento do incipiente poder econômico português e o esgarçamento das instituições. Foi para se contrapor a tal processo de falência institucional que D. João III tentou consolidar e organizar a corte portuguesa, ao mesmo tempo que, para manter o status de reino cimeiro no panorama europeu, investia no mecenato e na construção de obras ostentatórias.

Com tais propósitos, D. João III, embora tivesse uma personalidade ambígua e adotasse medidas contraditórias, conseguiu fortalecer o reino, elegendo as áreas de administração pública, organização política interna e cultura como prioritárias. Assim, estimulou as artes e o conhecimento técnico, e não é por acaso que, durante seu reinado, Portugal viu florescer alguns dos mais importantes nomes da cultura e da literatura portuguesa de todos os tempos. Tal é o caso de Gil Vicente, Bernardim Ribeiro, Sá de Miranda, Antônio Ferreira, Luís de Camões, Diogo Bernardes, João de Barros, Damião de Góis, André de Resende, Jerônimo Osório e Diogo de Teive, para citar apenas alguns dos mais conhecidos. Juntam-se a eles eméritos homens dedicados às ciências, caso de Garcia Horta, Pedro Nunes, Amato Lusitano ou Antônio Filipe, para ficarmos em poucos exemplos. 
O mecenato real foi louvado, na época, por muitos intelectuais de Portugal e mesmo do exterior, como o espanhol Vives ou o francês Fernel. ${ }^{2}$ Até mesmo Erasmo de Roterdã dedicou ao rei português uma de suas obras ${ }^{3}$, o que comprova o prestígio da corte lusitana e a circulação do nome do monarca.

Convém notar que D. João III investiu não apenas na arte, mas também na educação, procurando proporcionar uma estrutura renovada de ensino em Portugal, de duas maneiras: ora atraindo professores estrangeiros de renome, ora fundando instituições de peso, como os Colégios de Santa Cruz e de São Miguel, ou, notadamente, o Colégio das Artes, em 1547, em Coimbra, que se destinava, tal qual seu congênere francês, a renovar e refrescar o ambiente universitário português, graças à adoção de uma orientação renascentista. No caso deste colégio universitário, cabe lembrar que sua fundação ficou a cargo de um irmão de Antônio de Gouveia, o humanista André de Gouveia, que foi recrutado de Bordeaux, onde dirigia o Colégio da Guiena, especialmente para lançar as bases da nova instituição. André arregimentou vários professores estrangeiros, como George Buchanan e Nicolau de Grouchy ${ }^{4}$, além de atrair de volta ao país professores do porte de Diogo de Teive e Arnaldo Fabrício.

Também foi de D. João III a decisão de transferir definitivamente a universidade portuguesa para Coimbra, fato ocorrido em 1537, o que contribuiu para fortalecer a instituição. Por meio da contratação de novos professores, muitos deles estrangeiros, procurou elevar o nível da universidade, a fim de evitar que os estudantes portugueses fossem obrigados a se deslocar para o estrangeiro, em busca de melhor ensino.

2 Juan Luis Vives viveu entre 1492 e 1540. Nascido na Espanha, de origem judia, foi obrigado a percorrer a Europa, passando pela França, Inglaterra e Bélgica. Considerado um dos humanistas mais influentes e eruditos, escreveu cerca de sessenta obras, principalmente de filologia e filosofia. Jean François Fernel viveu entre 1497 e 1558. Médico francês, estudou no Colégio de Santa Bárbara, em Paris, e publicou diversas obras sobre fisiologia.

${ }^{3}$ Trata-se das Chrysostomi lucubrationes.

${ }^{4} \mathrm{O}$ escocês George Buchanan nasceu em 1506. Passou boa parte da vida na França, sendo professor em Bordeaux e Paris. Também lecionou em Coimbra, onde acabou preso pela Inquisição. Foi colega dos irmãos Gouveia e dedicou um poema a Antônio de Gouveia. Tendo retornado à Escócia, em 1561, para assumir funções relevantes na corte real e na universidade, faleceu em Edimburgo, em 1582. Nicolau de Grouchy, professor de filosofia, nascido em Rouen, em 1510, estudou em Paris, no Colégio de Santa Bárbara, e lecionou em Bordeaux, no Colégio da Guiena, e em Coimbra, no Colégio das Artes, a convite de André de Gouveia, entre 1548 e 1550. Faleceu em 1572, na França. 
Esse tipo de iniciativa não se contrapôs nem impediu a adoção de um procedimento complementar, que visava a favorecer a renovação intelectual no país: a criação, em 1527, de uma cota de bolsas de estudos para portugueses viajarem ao exterior, dobrando-se aos apelos de Diogo de Gouveia, importante humanista lusitano do período, tio de Antônio de Gouveia.

Como dito acima, não foi sob o reinado de D. João III que começou o êxodo de portugueses em busca de ensino de qualidade. O diferencial de D. João III foi o fato de estimular e estabilizar o fluxo de estudantes, fixando em cinqüenta o número de bolsistas em Paris. Essas bolsas vinculavam-se ao Colégio de Santa Bárbara (Collège de Sainte-Barbe), fundado em 1460, e que passou a funcionar como centro de reunião dos humanistas lusitanos em Paris. Alguns dos alunos beneficiados com a bolsa são João Ribeiro, Diogo de Teive, Antônio Leitão, Belchior Beleago e Simão Rodrigues. Segundo Luís de Matos (que fez um minucioso levantamento da presença de estudantes portugueses nos studia franceses), no ano de implantação da bolsa, 29 portugueses aproveitaram o benefício e ingressaram na universidade de Paris. ${ }^{5}$

Entre esses 29 bolsistas, encontrava-se justamente o poeta Antônio de Gouveia. Sétimo e derradeiro filho do casal Inês de Gouveia e Afonso López de Ayala, Antônio de Gouveia nasceu em Beja, cidade lusitana do Alentejo, em 1510, aproximadamente ${ }^{6}$. Foi a Paris, com bolsa concedida pelo rei D. João III, onde permaneceu de 1527 a 1534, estudando no Colégio de Santa Bárbara, na época dirigido por seu tio, Diogo de Gouveia Sênior. Após

${ }^{5}$ Cf. Luís de Matos, Sobre Antônio de Gouveia e a sua obra, pp. 7-8.

${ }^{6}$ A data de 1510 para o nascimento de Antônio de Gouveia é um esforço de dedução do Professor Joaquim Veríssimo Serrão, num cálculo que, realizado em 1966, não foi ainda confirmado ou desmentido. Tratase da melhor conjectura até hoje apresentada, razão por que vem aos poucos se firmando como a mais correta. Luís de Matos também reforça essa hipótese, e chega mesmo a afirmar provável que Gouveia tenha nascido até um pouco depois disso, por volta de 1513 (In Matos, Sobre António de Gouveia e a sua obra, p. 7). Em favor dessa hipótese, Luís de Matos lança mão de dois argumentos. Primeiro, parte do princípio de que os jovens ingressavam na universidade por volta dos quatorze anos. Assim, aceitando que Antônio iniciou a vida acadêmica em 1527, seria razoável supor que seu nascimento se deu em 1513. Além disso, Matos se apóia em outro dado: a afirmação, formulada por Gouveia, na dedicatória da obra Terentii Comoediae, de que teria iniciado os estudos literários na juventude, o que ratificaria a idéia de que começou a estudar em Paris com cerca de quatorze anos (Gouveia, carta-dedicatória a Guillaume du Bellay, in Terentii Comoediae Sex: "Nam a puero studiis me litterarum dedissem...”. [tradução: “Pois como me dediquei desde jovem aos estudos das letras...”]). Apesar de defender a data de 1513 como muito provável, Matos acaba por aceitar a fixação do nascimento do humanista em 1510, mas de modo nenhum antes disso. 
alcançar o título de Mestre em Artes, em 1534, foi convidado a lecionar em Bordeaux pelo irmão André, que havia assumido, nesse ano, a direção do Colégio da Guiena.

A troca de Paris por Bordeaux parece envolver uma desavença familiar. Como já se mencionou, foi o tio Diogo de Gouveia quem acolheu Antônio no seio da Universidade parisina, repetindo o que já havia feito com os sobrinhos Marcial e André, irmãos de Antônio. Entretanto, teriam surgido divergências entre André e Diogo, por conta de certas rivalidades na carreira e discordâncias na orientação religiosa. Diogo era um católico ortodoxo, combatente de qualquer nova interpretação do cristianismo, ao passo que André se envolveu nos debates religiosos e esteve mais atento aos novos ares do humanismo.

O conflito acirrou-se por motivos profissionais, pois André, ao sair da supervisão do tio e aceitar o cargo de principal em Bordeaux, além de receber um elevado salário, levou consigo muitos professores renomados, que lecionavam no Colégio de Santa Bárbara, dirigido por Diogo, provocando um certo esvaziamento e enfraquecimento na instituição comandada pelo tio.

Antônio tomou o partido do irmão, contra o tio, e, em 1534, após obter o mestrado, tomou o rumo de Bordeaux, indo juntar-se ao corpo docente do Colégio da Guiena, dirigido por André, contrariando o tio Diogo, que desejava que ele permanecesse em Paris, para se dedicar à Teologia e alcançar, futuramente, o grau de Doutor. ${ }^{7}$

Antônio de Gouveia permaneceu em Bordeaux por cerca de três anos, como docente de Artes, ensinando gramática e línguas clássicas. No início de 1538, retirou-se de Bordeaux. Após curtas passagens por algumas cidades francesas, dentre as quais Toulouse, Arles e Avignon (onde teria permanecido por seis meses), dirigiu-se, em fins de 1538 ou início de 1539, para Lyon.

Essa transferência inusitada nos conduz a uma grande dificuldade, que é estabelecer os motivos exatos que fizeram Gouveia partir de Bordeaux em janeiro de 1538 (segundo a datação proposta por Serrão ${ }^{8}$, abandonando o posto de docente do Colégio da Guiena, grandiosamente dirigido pelo irmão. Lembrando que Gouveia faz de tudo para se assimilar ao poeta Ovídio e, de certa forma, ser tido como um "novo" Ovídio, não deixa de ser curioso que

${ }^{7}$ É de notar que Antônio não menciona o tio em sua obra literária e, embora tenha composto mais de duas centenas de epigramas (em geral, poemas de circunstância), não dedicou nenhum ao parente. Por outro lado, André recebeu do irmão a dedicatória de epigramas altamente elogiosos.

${ }^{8}$ Serrão, op. cit., p. 57. 
nosso debate acabe por ter um sabor semelhante à discussão dos motivos insondáveis pelos quais o poeta de Verona foi exilado. Mas, seja como for, não nos furtemos ao debate.

Ao que tudo indica, e essa é uma opinião consensual entre os estudiosos, Gouveia teria deixado Bordeaux por ver-se envolvido em intrigas religiosos e por ser alvo de perseguição no interior da universidade, assim como ocorria naquele momento com vários outros colegas docentes, que se viram forçados a fugir, buscando refúgio na Suíça, caso de Maturin Cordier e André Zébédée (Zebedeu), ou em Agen, cidade às margens do Garonne que foi sede de um movimento reformista de que participaram alguns mestres bordeleses e também humanistas como Júlio César Scaliger.

Em Lyon, notável centro humanista com atividade editorial renomada, Antônio de Gouveia passou a trabalhar nas oficinas tipográficas de Sébastien Gryphe, um dos mais importantes impressores da Renascença européia. ${ }^{9}$ Foi nessa ocasião (e sob o selo de Gryphe) que publicou os dois livros de poemas latinos que constituem seu principal legado literário ${ }^{10}$, além de ser o responsável pela edição de obras de autores clássicos como Virgílio, Terêncio e Cícero ${ }^{11}$. Em Lyon, Antônio de Gouveia conviveu com artistas e humanistas, engajando-se no movimento intelectual da Renascença francesa. Foi ali, também, que entrou em contato com Émile Ferret (ou Emílio Ferreto), importante professor, diplomata e jurisconsulto de origem italiana, que despertou o interesse do português pelos Estudos Jurídicos, apresentando-lhe as novas doutrinas do Direito que mal começavam a se disseminar pela Europa.

Antônio de Gouveia residiu por cerca de três anos em Lyon, deixando essa cidade em fins de 1541, em direção a Paris, ao que parece para retomar a carreira acadêmica. Nesse segundo período em Paris, estudou Filosofia e tornou-se docente do Colégio de Santa Bárbara, agora dirigido pelo primo Diogo de Gouveia, o Moço. Além disso, manteve a atividade editorial, revendo a compilação de Terêncio e publicando comentários sobre Cícero e sobre a lógica aristotélica. Foram justamente suas pesquisas sobre Aristóteles que o fizeram entrar em rota de colisão com Pierre de la Ramée (latinizado Petrus Ramus), jovem filósofo que vinha causando furor nos meios universitários parisienses por seus ataques à doutrina

${ }^{9}$ Antônio de Gouveia já se encontrava residindo em Lyon no primeiro semestre de 1539, como se pode depreender da dedicatória de seu primeiro livro de poemas, que é datada de 30 de abril de 1539.

10 Trata-se das obras Epigrammaton Libri Duo e Epigrammata, Eiusdem Epistolae Quattuor.

${ }^{11}$ Por exemplo, as obras Terentii Comoediae, Virgilii Opera e In M. T. Cic. Orationem In Vatinium Commentarius, este último publicado em Paris, em 1542. 
escolástica, tendo arrebatado uma enorme legião de seguidores, ao propor uma completa renovação dos estudos acadêmicos. Sem receio de entrar numa acirrada polêmica filosófica, Gouveia publica, em novembro de 1543, a obra Pro Aristotele responsio aduersus Petri Rami calumnias $^{12}$. Diante da turbulência que tal enfrentamento causou na Universidade de Paris, o rei Francisco I interveio e marcou uma audição, para que se arbitrasse a disputa. Em fevereiro de 1544, tem lugar o debate, que termina com a condenação de Ramée e a atribuição da vitória a Gouveia.

Surpreendentemente, no entanto, por algum motivo ainda ignorado, nesse mesmo ano de 1544, após um triênio de residência em Paris, Antônio renunciou aos louros da vitória, abandonou a capital francesa e partiu para Toulouse, onde viria a completar a formação em Direito, no segundo semestre de 1548, mediante a obtenção do grau de doutor. Durante esse período, foi discípulo destacado e publicou estudos sobre Cícero e sobre legislação.

Já doutor, passou a dedicar-se ao magistério e à pesquisa na área dos Estudos Jurídicos, lecionando inicialmente nas cidades francesas de Cahors (1549 a 1554), Valence (1554-1555) e Grenoble (1555-1562).

Quando a Universidade de Grenoble cessou as atividades, em 1562, devido a conflitos internos, problemas financeiros e, sobretudo, à eclosão da guerra religiosa, que opôs católicos e calvinistas num confronto violento, Antônio de Gouveia aceitou o convite do duque da Sabóia, Emanuel Filisberto, que havia fundado, em 1560, uma universidade em Mondovì, e foi lecionar em solo italiano. Em 1565, a universidade é transferida de volta para Turim, e Gouveia acompanha a mudança para a capital piemontesa, onde viria a falecer, em 5 de março de 1566.

Antes de avançar algumas considerações e aprofundamentos a respeito da trajetória de vida de Antônio de Gouveia, convém ressaltar a importância de toda a sua família no contexto do humanismo português. Sem dúvida, alguns fatos mencionados acima já permitem perceber o bom relacionamento da família com os meios humanísticos e sua presença na própria vida do poeta português. Tal projeção da família Gouveia inicia-se justamente pelo tio de Antônio, Diogo de Gouveia, Sênior, o acima referido mentor das bolsas portuguesas concedidas por D. João III. Nascido igualmente em Beja, cerca de 1467, Diogo foi estudar na Universidade de Paris, onde obteve, em 1500, o grau de Mestre em Artes, e, em 1510, o de Licenciado em

12 Tenha-se em conta que, dois meses antes, isto é, em setembro de 1543, Ramée havia dado à luz dois livros de violenta crítica à doutrina aristotélica. 
Teologia. Nessa Universidade, exerceu os cargos de reitor (entre 1500 e 1501), bibliotecário (1507), principal do Colégio de Santa Bárbara (a partir de 1520) e diretor da Faculdade de Teologia (1545). Foi durante seu principalato em Santa Bárbara que Diogo de Gouveia convenceu o rei lusitano a conceder bolsas de estudo para jovens compatriotas, que passaram a freqüentar essa instituição parisiense a partir de 1527, transformando-a num pólo de estudos universitários de portugueses em terras francesas. Diogo de Gouveia também desempenhou missões diplomáticas a cargo dos reis D. Manuel e D. João III, e, por todo esse conjunto de atividades, teve papel importante na promoção da cultura e da diplomacia portuguesa.

Mas também é preciso salientar que Diogo, assumindo uma posição ortodoxa perante a guerra religiosa, hostilizou muitos pensadores humanistas, e foi ele, aliás, um dos maiores instigadores da Inquisição na Universidade de Coimbra, fator que prejudicou sobretudo o Colégio das Artes, instituição fundada em 1547 por seu sobrinho André de Gouveia e que acabou por ser transferida à autoridade dos jesuítas, em 1555.

Se, no fim da vida, Diogo de Gouveia adotou uma posição conservadora, contrareformista, isso não nos impede de reconhecer que, nas primeiras décadas do Quinhentos, ele foi um dos grandes incentivadores da educação humanística em Portugal. Inúmeros intelectuais se beneficiaram das portas que Diogo de Gouveia abriu. Exemplos disso são os próprios sobrinhos, que, sob os auspícios do tio, se deslocaram à França, onde se iniciaram na carreira acadêmica.

Com efeito, Antônio de Gouveia não foi o primeiro sobrinho de Diogo a ser atraído pelo tio para estudar naquele país. Antes dele, dois de seus irmãos já haviam passado por Paris e, a partir daí, tomado o rumo da carreira intelectual. O mais velho, Marcial de Gouveia $^{13}$, após concluir seus estudos em Paris, junto ao tio, peregrinou, como ilustre professor, pela França, Itália e Alemanha, chegando a manter contato com protagonistas do humanismo e da reforma, como Erasmo e Melanchton. Finalmente, retornou a Portugal, a convite de D. João III, por volta de 1540, passando a lecionar em Braga e em Coimbra, onde foi preso pela Inquisição, em 1551.

André de Gouveia, outro irmão de Antônio, nascido por volta de 1503, estudou no Colégio de Santa Bárbara, em Paris, já sob o principalato do tio Diogo, obtendo o grau de Mestre em Artes em 1528. Substituiu ao tio no principalato, que exerceu entre 1530 e 1534, quando foi convidado a assumir o principalato do Colégio da Guiena, em Bordeaux, cargo

\footnotetext{
${ }^{13}$ Nascido por volta de 1501.
} 
que ocupou até 1547. Nessa posição, angariou grande prestígio, sendo mesmo elogiado por Montaigne, seu aluno, nos Ensaios ${ }^{14}$. Após treze anos na direção da instituição bordalesa, foi chamado a Portugal pelo rei D. João III, com a missão de fundar o Colégio das Artes, em Coimbra. Mas, somente um ano após a instalação do Colégio, veio a falecer.

Além deles, mais um membro da família Gouveia educou-se em Paris e teve participação na trajetória intelectual de Antônio. Trata-se de Diogo de Gouveia, o Moço, também sobrinho de Diogo de Gouveia, Sênior, primo de Antônio de Gouveia, igualmente educado em Paris pelo tio (de quem é diferenciado pela alcunhas "Sênior" e "Moço", pois são homônimos), que viria a substituir o primo André na direção do Colégio de Santa Bárbara, a partir de 1535, mantendo-se no cargo até 1544, data em que retornou a Portugal, já licenciado e doutor em Teologia. Durante o período em Paris, foi designado reitor da Universidade, entre 1538 e 1539. Mais tarde, em Portugal, foi nomeado principal do Colégio das Artes, em 1548, mais uma vez substituindo o primo André, que havia falecido. Exerceu funções eclesiásticas, foi embaixador de D. João III no Concílio de Trento e veio a falecer em 1576, no Convento de Palmela, na região do Ribatejo.

Como se vê, a família Gouveia teve papel de relevo no quadro intelectual e acadêmico renascentista, não apenas em Portugal, mas em países da Europa Ocidental, como França, Itália e Alemanha, sendo considerada por Ramalho "a mais célebre família de humanistas portugueses do Renascimento"

O membros dessa família encarnam o perfil típico do humanista do Renascimento por uma série de fatores indicados nos esboços biográficos apresentados acima: todos empreenderam viagens de estudo, titularam-se em Paris, um dos mais importantes centros universitários do continente (e o de maior prestígio na França), desempenharam funções docentes, desfrutaram da convivência com intelectuais célebres, percorreram a Europa na difusão do conhecimento, dominavam perfeitamente as línguas clássicas, perseguiam um ideal do sábio humanista, influenciados pelas principais correntes do pensamento do período e pelas doutrinas poéticas e filosóficas de Petrarca. Em suma, todos têm efetiva participação no que se convencionou chamar de Humanismo.

\footnotetext{
${ }^{14}$ Vide Michel de Montaigne, Essais, I, cap. 26 (De L’Institution des Enfans): “Andreas Goveanus (...) fut sans comparaison le plus grand principal de France".

${ }^{15}$ Ramalho, A. C. Verbete "Diogo de Gouveia" in Biblos, p. 869.
} 
No caso de Antônio de Gouveia, sua trajetória reforça decisivamente essa imagem. Retomemos, portanto, alguns desses aspectos, a fim de desenvolvê-los um pouco mais.

Um primeiro aspecto, tipicamente humanista, a ponto de render a designação do movimento, concerne à formação nas litterae humaniores. Em relação a isso, Gouveia recebeu, nos dizeres de Serrão, "uma preparação clássica de alto nível, dominando as línguas, a história e a filosofia"16. Verdadeiramente, a educação humanística é a fonte e origem do movimento, e Gouveia, imbuído desse ideal, soube juntar esses elementos formativos na análise do direito, exercendo não apenas o papel de jurista, mas o de verdadeiro filólogo, caráter que determinava a essência da arte jurídica do seu século.

Relacionado à formação, observamos em Gouveia outro elemento essencial e distintivo do humanista: o conhecimento das línguas clássicas, o estudo e o comentário de autores latinos, a edição de livros. Todas essas atividades foram empreendidas pelo poeta português. Quanto ao domínio das línguas clássicas, ele pode ser comprovado não apenas pela análise da titulação do poeta, mas pelo fato de que Antônio seguiu a carreira acadêmica, no ramo das artes humanísticas, e se tornou professor dessas línguas. Em relação ao latim, além das aulas, Gouveia foi o revisor responsável pela edição de obras clássicas de Virgílio e Terêncio, como já mencionado acima, e contribuiu, nas publicações, com prefácios, notas e comentários, sem falar dos minuciosos e amplos estudos sobre discursos e obras de Cícero.

Em relação ao grego, chegou até nós um opúsculo bastante breve, de sua autoria, de caráter didático, ensinando o alfabeto grego a estudantes universitários. Trata-se do Alphabetum Graecum, publicado em Lyon, em 1540, e provavelmente elaborado em função de um outro lavor típico dos humanistas do Renascimento: a preceptura e o ensino privado de membros das famílias abastadas da Europa. Uma das contrapartidas dessa atividade, aliás, era a obtenção de apoio de importantes mecenas, que permitiam aos humanistas, como Gouveia, os recursos para que se dedicassem à produção literária. ${ }^{17}$

Outra característica típica dos humanistas é relevante em Gouveia: a busca de conhecimento e o interesse por uma ciência multidisciplinar. Com efeito, podemos verificar que ele estudou por toda a vida, e dedicou-se a campos do saber distintos e complementares, como a filologia, a filosofia e o direito. Embora tenha dedicado a maior parte de sua vida à

\footnotetext{
${ }^{16}$ Serrão, op. cit., p. 290.

17 Note-se, a esse respeito, que a pequena obra é dedicada a Robert-Reynaud d'Alein (alatinado
} Robertus Reginaldus Alenius), filho de Jacques de Reinaud, senhor de Alein. 
pesquisa e ao ensino das ciências jurídicas, passou antes por etapas fundamentais nas áreas da filologia e da filosofia, publicando obras relevantes em ambas. Além disso, sempre procurou conciliar todos os objetos de estudo e, seguindo o pensamento ciceroniano da humanitas, acreditava que o conhecimento literário e filosófico são condições indispensáveis para o aprimoramento de qualquer atividade jurídica, na medida em que estabelecem as bases profundas e verdadeiramente humanas sobre as quais se implanta a doutrina das leis. As inquietações intelectuais próprias de seu caráter o levaram a galgar os mais variados graus da carreira acadêmica e buscar sempre um novo desafio intelectual, diferente do anterior, ainda que complementar e inter-relacionado, estabelecendo pontes interdisciplinares entre poética, retórica, filosofia e direito, mas projetando-se sempre para além do domínio já experimentado.

Parcialmente vinculada a essa inquietude, podemos apontar mais uma característica que Gouveia compartilha com muitos humanistas: a constante peregrinação, a passagem por diferentes cidades, a ânsia de conhecer novas terras e arregimentar novos discípulos. Essa peregrinação, relacionada a um ideal de difusão cultural e científica, é como que programática dentro do movimento humanista. No caso de Gouveia, verifiquemos por quantas cidades ele passou ao longo da vida. Mesmo se excluirmos os lugares onde ele esteve provisoriamente durante sua transferência de Bordeaux a Lyon, constataremos que residiu em pelo menos nove cidades (Paris, Bordeaux, Lyon, Toulouse, Cahors, Valence, Grenoble, Mondovì e Torino), nelas permanecendo por períodos muito variados, mas nunca por mais de sete anos. Além dessas cidades, os principais biógrafos de Antônio acrescentam, pelo menos, Avignon à listagem, cuja importância na vida do poeta pode ser julgada pelas referências diretas e indiretas a essa cidade em sua obra poética. É importante notar que, em todas as cidades mencionadas, Gouveia sempre se ligou à vida universitária, seja como aluno, seja como professor, seja das duas maneiras. Portanto, a grande circulação pelo território europeu, que também observamos em inúmeros outros humanistas, no caso de Gouveia está caracteristicamente vinculada ao relacionamento institucional que ele estabelecia com a universidade. Contribuiu para isso o fato de que, no auge do Renascimento, as universidades passaram a disputar os docentes mais famosos, pois isso atraía alunos e prestígio para o Studium. Ademais, os humanistas, envoltos numa mística de internacionalização do saber e crendo-se um pouco apátridas, a serviço da cultura e das letras, fiéis sobretudo ao mundo clássico e à língua latina, enxergavam muitas vezes a Europa como uma grande massa continental indistinta. Essa mesma ideologia pode ser observada em Gouveia, que poucas referências faz à sua pátria, nos poemas, e dá muito menos importância ao seu local de 
nascimento do que à herança clássica. Não espanta, conseqüentemente, que seu trabalho seja recheado de citações dos clássicos e que os autores antigos sejam sua fonte primordial. A nosso ver, não seria exagero afirmar que a pátria de Gouveia é a literatura clássica, predominantemente (mas não apenas) a latina, pois é dela que emanam a inspiração, a matéria, a identidade e o viés ideológico de sua obra, e não das paisagens ou da cultura do seu país de nascimento.

Os humanistas também substituíram o apego à pátria pelo envolvimento congregacionário numa comunidade intelectual, que formava uma elite douta de cidadãos humanistas, vinculados num verdadeiro mundo à parte. Tal confraria se caracteriza, nitidamente, como um movimento artístico e cultural, em que um grupo de pessoas, compartilhando idéias e vivências, planos e objetivos comuns, difunde determinados ideais da esfera cultural (e política, ideológica e até mesmo, na época, religiosa).

Também esse traço típico de inserção numa classe intelectual coesa e segregada aparece em Gouveia, pois durante sua vida são inúmeros os contatos (mais ou menos estreitos) com outros importantes humanistas, tanto portugueses quanto de outros países. Esse aspecto, aliás, está refletido na obra poética de Gouveia, recheada de dedicatórias ou versos a humanistas coevos, para não falar das alusões intertextuais que compõem sua poesia.

Entre os intelectuais portugueses que se relacionaram com Antônio de Gouveia, podemos citar, de início, os importantes humanistas Diogo de Teive e João da Costa, que foram seus colegas de estudo, em Paris, matriculados no mesmo Colégio de Santa Bárbara (e, posteriormente, colegas de trabalho dos irmãos de Antônio de Gouveia, em Coimbra). Diogo de Teive também foi colega de docência de Antônio (e André) em Bordeaux, aonde chegou no outono de 1536. Antônio estava lá desde janeiro de 1535 (e ficou até 1537). André havia assumido o Principalato a partir de 1534 (por contrato de julho desse ano), e ficou por mais de uma década, até 1547.

Ao lado de Diogo de Teive e João da Costa, Gouveia menciona e dedica epigramas, no livro de 1540, a dois outros colegas da temporada em Paris, Bartolomeu Montano e Pedro Álvaro. Mas o número de colegas portugueses foi muito maior, se tivermos em conta a já mencionada listagem elaborada por Luís de Matos, que aponta que, em 1527, juntamente com Antônio de Gouveia, inscreveram-se na Universidade de Paris outros vinte e oito 
compatriotas, como Álvaro da Fonseca, Antônio Pinheiro, Gaspar Bordalo, João da Costa e Manuel Cerveira, oriundos das diferentes regiões do país ${ }^{18}$.

Além dessa importante circulação de intelectuais portugueses pela Europa, que gerou uma agregação entre eles, devemos lembrar, no caso de Gouveia, sua convivência com alguns dos mais afamados poetas e professores franceses do século XVI, como Jules César Scaliger, André Zébédée e Marc-Antoine Muret ${ }^{19}$. Este último foi colega de docência de Gouveia em Bordeaux, no Colégio da Guiena, entre 1545 e 1547, e escreveu poemas dedicados ao humanista português.

Outro nome que faz parte da história de vida de Gouveia é o de Émile Ferret (ou Emílio Ferreto), professor e humanista francês de origem italiana que, como dissemos, descortinou o campo do Direito aos olhos de Gouveia. Émile Ferret, nascido em 1489, formou-se doutor e foi professor de direito em Roma, bem como secretário do papa Leão X, antes de se fixar em Lyon, por volta de 1530. Em 1547, mudou-se para Avignon, contratado pela universidade local, tendo falecido em 1551.

Assim como Ferret direcionou Antônio de Gouveia, não podemos deixar de mencionar o fato simétrico, constantemente recordado por Serrão, de Antônio haver encaminhado para as novas linhas de pesquisa do direito àquele que viria a ser o mais famoso jurisconsulto do período, o francês Jacques Cujas (Cujácio) ${ }^{20}$. Gouveia preencheu esse papel na condição de professor e amigo pessoal do célebre jurista, que, por sinal, substituiu Gouveia no Studium de

${ }^{18}$ Cf. Matos, op. cit., 1966, p. 7.

${ }^{19}$ Jules César Scaliger, nascido em Verona, em 1484, naturalizou-se francês e viveu na cidade de Agen, onde faleceu em 1558. Humanista polêmico, deixou inúmeras obras, dos mais variados campos de estudo, abrangendo poética, ciências naturais, filosofia e filologia. Também esteve envolvido nos conflitos religiosos do período. André Zébédée, professor francês, perseguido durante as guerras religiosas por sua adesão à reforma, refugiou-se na Suíça. Marc-Antoine Muret, humanista francês, nascido em 1526, faleceu em Roma, em 1585. Foi professor em Bordeaux, contemporâneo dos Gouveias, e editou muitas obras clássicas de literatura e filosofia.

${ }^{20}$ Jacques Cujas, denominado Cujácio a partir da forma latinizada de seu nome, nasceu em Toulouse, em 1520, e morreu em Bourges, em 1590. Foi um dos mais reputados defensores da interpretação moderna do direito, a chamada escola cujaciana (ou método cujaciano). Sua principal atividade foi como professor e pesquisador das ciências jurídicas, e suas aulas foram amplamente publicadas. Sua fama o levou a lecionar em Toulouse, Cahors, Valence, Turim, Paris e Bourges. 
Cahors, em 1554, quando o português mudou-se para Valence ${ }^{21}$. Alguns historiadores mencionam o fato de que o professor português representou uma influência fundamental na formação do francês.

Ao lado do convívio intelectual e universitário, o prestígio dos humanistas mais afamados fazia com que eles tivessem contato, igualmente, com membros de grupos sociais poderosos, como nobres, parlamentares, médicos ou comerciantes ricos. Também nesse ponto observamos que Gouveia desfrutou da amizade ou, pelo menos, de algum contato, com pessoas importantes das cidades por onde passou, e soube se inserir não apenas nos círculos artísticos, literários e acadêmicos, como também nos meios sociais e políticos elevados. A esse respeito, Serrão ajunta uma série de dados sobre personalidades que privaram do contato com o humanista, às quais o português dedicou inúmeras composições.

Essas figuras de projeção política se constituíam em protetores de Gouveia, mas os relacionamentos também eram reforçados pelo fato de que muitos desses membros da elite do país, fossem parlamentares ou médicos, estavam envolvidos nas transformações culturais e nos círculos humanistas de renovação poética, artística ou científica. Citem-se, a esse respeito, Pierre de Ciret, Arnaud Ferron e Jean de Yberrola. Este último, por exemplo, foi não somente conselheiro do Parlamento, mas também Reitor da Universidade de Bordeaux. Quanto a Ciret e Ferron, foram conselheiros no parlamento da mesma cidade. Outro nome, citado por Serrão, é Briand de la Vallée, o qual, posteriormente, tornou-se desafeto de Gouveia. ${ }^{22}$ Vallée também foi parlamentar em Bordeaux e, nessa condição, foi reconhecido protetor da universidade bordelesa.

Além desses eminentes políticos bordeleses, cabe mencionar o jurista Jean de Boyssoné, parlamentar em Toulouse e Chambéry, que levou uma vida atribulada em função dos conflitos religiosos nos quais esteve envolvido.

Também devemos incluir médicos como Francisco Valeriolla, a quem Gouveia dedica um epigrama, e Giovanni Romano, a quem dirige, além de epigramas, a carta-dedicatória de

${ }^{21}$ Como exemplo da deferência que Cujácio tinha por Gouveia, a quem considerava "summus amicus suus”, Joaquim Serrão cita o seguinte trecho da obra Notae ad titulum Ulpiani, de Cujácio: “Antonius Goueanus cui ex omnibus quotquot sunt aut fuere Iustinianei iuris interpretes si quaeramus quis unus excellat palma deferenda est" [tradução: "Caso procuremos, dentre todos aqueles que são ou foram intérpretes do Direito Justiniano, quem, sozinho, supera os demais, a Antônio de Gouveia deve ser dada a palma"]. Serrão, op. cit., p. 13, nota 1. Cf. também pp. 206-8.

${ }^{22}$ Cf. Serrão, op. cit., p. 53 et sqq. 
abertura do conjunto das cartas poéticas. Outro protetor, que também é agraciado com um poema, é o embaixador português na França, Rui Fernandes de Alamada.

Por não haver espaço cabível para apresentar, nesta tese, uma lista detalhada de políticos e personalidades referidas por Gouveia, ou que estenderam sua influência até poeta lusitano, resta-nos indicar a obra de pesquisa biográfica de Joaquim Veríssimo Serrão, que aponta um sem-número de pessoas que protegeram o humanista português em suas andanças pela França.

Esses bons relacionamentos na sociedade e sua reconhecida associação ao movimento humanista ajudam a explicar sua participação na polêmica contra Pierre de la Ramée (Petrus Ramus) e o convite régio para que ele, Gouveia, representasse a universidade no julgamento público da discórdia entre as duas correntes universitárias que se digladiavam, em Paris, pelo controle da concepção do ensino filosófico: os escolásticos e os reformadores antiaristotélicos. O papel de Antônio de Gouveia na contenda indica claramente a inserção institucional do português nos principais meios acadêmicos, e, por outro lado, é um importante demonstrativo do ponto-de-vista humanista e reformador com que o pensador português debateu a questão do valor da filosofia aristotélica, pois ele, embora sustentando a causa do ensino tradicional, afastou-se da restritiva interpretação escolástica de Aristóteles e buscou repor o valor original do texto, numa "forma de exaltação clássica" 23 , para usar as palavras precisas de Serrão.

Passando da filosofia para o direito, é possível perceber que essa mesma visão classicista, impregnada do mais puro sentido renascentista de encarar as questões relacionadas à pesquisa e ao ensino e propor reformas profundas, está na origem do papel revolucionário de Antônio de Gouveia no campo jurídico.

Aliás, antes mesmo de falarmos dos êxitos alcançados por Antônio de Gouveia no direito, cabe apontar que a própria opção do poeta pelos Estudos Jurídicos assinala seu apego aos ideais de uma fraternidade de humanistas que valorizavam uma sociedade laica e buscavam expandir o panorama cultural e referencial da época, redimensionando o papel da igreja e a visão marcadamente teocêntrica de interpretação dos fenômenos naturais e sociais. É dessa forma que, a nosso ver, devemos interpretar a rejeição, por parte de Antônio, da proposta de Diogo de Gouveia, que desejava que seu sobrinho seguisse o curso de Teologia em Paris. Antônio de Gouveia, como vimos, rejeitou essa via de estudo, e se inclinaria, afinal,

\footnotetext{
${ }^{23}$ Serrão, op. cit., p. 23.
} 
para o estudo jurídico. Isso mostra, repita-se, o engajamento de Gouveia nos ideais classicistas do Renascimento, que se afasta da pesquisa estritamente teológica para enfatizar, na investigação moderna das fontes do direito romano, uma nova explicação das relações sociais. Nesse sentido, é sintomática a opção por um campo laico de estudos, fortalecido pelas aspirações defendidas pelos humanistas. Com efeito, um dos aspectos indicativos da mentalidade classicista do humanismo reside justamente na importância atribuída ao envolvimento em outros campos de estudos, que se encontravam em profunda modificação e inovação, como era o caso do Direito. Segundo Serrão, essa opção por uma trilha laica de estudos aproxima Antônio de Gouveia do humanista Diogo de Teive, pois ambos compartilham esse mesmo traço em suas vidas. ${ }^{24}$

Porém, uma vez tendo optado por esse campo de estudos, o papel reservado a Antônio de Gouveia foi de grande relevo: com efeito, ele foi um dos pioneiros na difusão e consolidação do chamado método histórico de interpretação da leis, também conhecido por mos gallicus (em contraposição ao mos italicus, de concepção medieval). Antônio de Gouveia, considerado na época um dos mais importantes jurisconsultos de toda a Europa e disputado a peso de ouro pelas principais universidades do Velho Continente ${ }^{25}$, estabeleceu alguns dos principais parâmetros de análise jurídica que compuseram a doutrina moderna do Direito, incorporados na obra de Cujácio, discípulo do humanista português. O que hoje chamamos de método cujaciano deve muito de sua essência ao trabalho de Gouveia como professor e autor de livros, especialmente durante os últimos quinze anos de sua vida. E tudo isso sem abandonar a veia poética, como provam os versos esparsos que continuou a escrever durante os anos de dedicação aos Estudos Jurídicos.

Segundo Serrão, um sinal evidente do prestígio do humanista português foi a publicação de suas obras jurídicas completas, em Lyon, em 1561, com nova tiragem em 1562. Essa compilação, organizada por Gouveia, ainda em vida, representa, no dizer de Veríssimo Serrão, "a plena realização, ao mesmo tempo, como doutrinador e escritor", sendo mesmo uma façanha de grande glória na época e o objetivo da vida acadêmica de muitos professores

${ }^{24}$ Cf. Serrão, op. cit., p. 49.

${ }^{25}$ Segundo Serrão, op. cit., p. 220, Gouveia, por volta de 1555, chegou a ser "considerado, no mundo do Direito, como o regente mais famoso que ensinava nas Escolas francesas" e "o mais cotado dos mestres de Direito do seu tempo". 
universitários de então, "o momento de consagração", como repete o biógrafo de Gouveia ${ }^{26}$. E o brilho do humanista português foi ainda maior se levarmos em consideração que a obra ganhou reedições póstumas em 1599 e 1622.

Contudo, gostaríamos de encerrar o presente capítulo retomando o período mais diretamente vinculado ao de sua produção poética, período esse de evidente engajamento no movimento humanista: trata-se de sua residência em Lyon e sua participação nos meios eruditos e humanistas daquela cidade, em plena Renascença. Sobre esse tópico, aliás, o professor Serrão traz à luz uma série de informações e oferece-nos um excelente painel do movimento humanista e da intensa participação de Gouveia, naquele momento de sua vida, nas atividades intelectuais de vanguarda da elite lionesa.

Serrão nos mostra que a cidade de Lyon, em parte graças à sua excelente localização, na confluência das rotas do Mediterrâneo, da Itália e de Flandres, para além de grande pólo comercial e uma das maiores cidades da França, tornou-se "centro da Cultura francesa do Renascimento"27, ostentando o maior núcleo tipográfico do país. Com efeito, a atividade impressora era intensa e, nos dizeres de Serrão, "os prelos não cessavam de lançar obras no mercado, a um ritmo de produção cada vez maior" ${ }^{28}$. Poucos anos antes de Gouveia instalarse naquela cidade, Rabelais publicou seu livro "Gargantua", pelo mesma oficina impressora (de Sébastien Gryphe) onde o português viria a trabalhar como revisor, a partir de 1539, e a publicar suas próprias obras poéticas.

Entretanto, havia muitos outros poetas e humanistas, além de Rabelais. Serrão cita, dentre tantas figuras eminentes da época, aqueles que mantiveram uma ligação mais próxima com Antônio de Gouveia, como é o caso de Guillaume Scève, corretor principal da casa tipográfica de Sébastien Gryphe e protetor de Gouveia; Jean Visagier, citado por Gouveia pelo nome latinizado, Vulterius; Étienne Dolet, um dos mártires da Reforma francesa; e os poetas Gilbert Ducher, Nicolas de Bourbon, Bonaventure des Périers e Clément Marot ${ }^{29}$.

${ }^{26}$ Serrão, op. cit., p. 297. O historiador mostra que esse tipo de publicação era, na época, o principal instrumento para angariar prestígio e divulgar o pensamento, pois permitia ao autor ver as suas idéias espalhadas por Bibliotecas e Universidades.

${ }^{27}$ Serrão, op. cit., p. 74.

${ }^{28}$ Serrão, op. cit., p. 78.

${ }^{29}$ Com exceção de Étienne Dolet, que será apresentado a seguir, ao longo do texto principal, resolvemos sintetizar, nesta nota de rodapé, as principais informações biográficas obtidas sobre os referidos intelectuais. Guillaume Scève era irmão de Maurice Scève, poeta que encabeçava o movimento literário em 
Esses poucos nomes já dão bem uma idéia da intensa movimentação que ocorria nos meios intelectuais renascentistas de Lyon. E a referência que Gouveia faz deles indica claramente a participação do português no seio da renovação cultural que acontecia na França, naquele momento. O lusitano circulava entre eles e desempenhava papel cada vez mais relevante como letrado e poeta. Ademais, segundo registra Serrão, Gouveia chegou mesmo a residir na casa de Gryphe ${ }^{30}$.

Não por acaso, seus epigramas são dedicados - além dos nomes referidos acima - a figuras como Jean Salmon Macrin (1490-1557), poeta neolatino influente na época, que se gabava de haver difundido na França a obra de Catulo e Horácio, e que se inspirava no trabalho de autores da poesia neolatina italiana, como Pontano, Poliziano e Sannazaro; ou Mellin de Saint-Gelais (1491-1558), formado em Bolonha e Pádua, poeta oficial da corte de Francisco I, autor de poesia neolatina extensa e aclamada, além de sonetos inspirados em Petrarca. Ambos foram humanistas reputados, em plena atividade nas décadas de 1520 e 1530.

Dos nomes alinhados acima, é importante nos estendermos sobre a figura de Étienne Dolet, um dos mais importantes humanistas do período, que comparece em vários epigramas de Gouveia, sendo retratado em alguns de maneira francamente jocosa. Ele viveu entre 1509 e

Lyon. Guillaume, de formação humanística, dedicou-se à edição de livros. Jean Visagier, também conhecido por Jean Voulté ou Vouté (latinizado Ioannes Vulteius), viveu entre 1505 e 1542. Estudou no Colégio de Santa Bárbara, em Paris, e integrou a escola lionesa de poesia neolatina, ao lado de nomes como Dolet, Ducher, Bourbon e Beaulieu. Seus epigramas influenciaram a obra de Gouveia, que os cita em algumas passagens. Nicolas de Bourbon (1503-1550) foi um dos mais aclamados poetas neolatinos do período. Publicou uma edição de sua obra Nugae, em 1533, revista em 1538, com cerca de seiscentos epigramas. Da mesma forma que Visagier, influenciou Gouveia com seu estilo de composição. Bourbon também teve acesso à casa real da Sabóia e foi preceptor da filha da rainha Margarida de Navarra, conhecida protetora dos humanistas. Gilbert Ducher, poeta que fez parte do grupo de poetas neolatinos de Lyon, também trabalhava na editora de Gryphe, sendo o responsável por uma edição dos epigramas de Marcial. Além da atividade literária, foi professor de direito em Lyon, tendo obtido a formação jurídica em Toulouse e Paris. Bonaventure des Périers (1510-1544) teve formação humanista e trabalhou na edição de diversas obras clássicas. Tornou-se conhecido como autor do polêmico livro Cymbalum Mundi. Clément Marot, nascido em Cahors, filho do professor de retórica Jean Marot, por volta de 1497, e falecido em Turim, em 1544, foi um dos mais importantes poetas do Renascimento francês. Protegido do rei Francisco I, vinculou-se à corte francesa. Além de centenas de composições próprias (rondós, canções, baladas, elegias, epitáfios, epístolas, etc.), foi tradutor de Virgílio, Ovídio, Luciano, Petrarca, e de Salmos de Davi, bem como de obras de poetas neolatinos.

${ }^{30}$ Cf. Serrão, op. cit., p. 79. 
1546, destacando-se como poeta, escritor e editor. Estudou em Paris, Pádua e Toulouse. Envolveu-se numa polêmica literária com Erasmo e, a partir disso, surgiram suas primeiras obras, publicadas por Sébastien Gryphe, de quem viria a tornar-se amigo pessoal. Por conta dessa ligação, e de seu bom relacionamento com o rei Francisco I, Dolet decidiu instalar-se em Lyon, a partir de 1535, com o privilégio real de imprimir obras em grego, latim, italiano e francês, tornando-se um importante e fecundo poeta neolatino e o líder do círculo literário lionês. Além de publicar em profusão autores da Antigüidade clássica, foi o primeiro editor de Clément Marot. Em conseqüência de suas obras satíricas muito incisivas, colecionou grande número de inimigos, que conseguiram conduzi-lo à prisão, em 1544, sob a acusação de ateísmo. Uma vez envolvido nas guerras religiosas, considerado ou ateu ou adepto do luteranismo, foi constantemente perseguido, até ser condenado pelos tribunais da Inquisição, em 1546, a ser torturado, enforcado e queimado em praça pública, juntamente com seus livros, em Paris, nesse mesmo ano.

Antônio de Gouveia entrou em contato com Dolet no momento em que o humanista francês estava no auge de sua atividade intelectual, e as marcas de sua influência na obra do poeta português são visíveis, seja nas escolhas relacionadas a esse gênero poético, seja na temática, no estilo ou no vocabulário, seja nas dedicatórias e nas alusões poéticas.

Enfim, pensamos ter alcançado o que propúnhamos demonstrar neste capítulo, a saber, que Antônio de Gouveia foi um poeta plenamente engajado e reconhecido no movimento humanista, e o autor de uma obra que apresenta reflexos indiscutíveis desse engajamento intelectual, conforme veremos, mais minuciosamente, a seguir. 


\section{Capítulo 2}

\section{A COMPOSIÇÃO POÉTICA DE ANTÔNIO DE GOUVEIA}

É possível verificar que a obra poética de Antônio de Gouveia foi profundamente influenciada pelo ambiente cultural da Lyon renascentista. Nessa cidade francesa circulavam alguns dos mais importantes humanistas europeus, e suas gráficas ocupavam posição proeminente no cenário da época. Foi ali que, nos anos de 1539 e 1540, Gouveia publicou sua obra poética, pela casa impressora de Sébastien Gryphe, a mais importante da região.

Segundo Luís de Matos, o principal propósito da produção de Gouveia foi rivalizar com os intelectuais franceses e colocar-se à altura de seus contemporâneos. ${ }^{31}$ Embora esse julgamento seja questionável, é inegável a influência dos escritores neolatinos coevos no processo de criação literária de Gouveia.

A produção poética neolatina é, em boa parte, fruto dos estudos filológicos e literários empreendidos pelos humanistas. Observando e valorizando os autores clássicos, os poetas renascentistas passaram a imitá-los, adotando-os como modelos a serem seguidos.

Assim, houve uma onda de reprodução dos princípios poéticos da Antigüidade. Um dos aspectos da literatura clássica respeitado pelos autores do século XVI é a composição genérica, isto é, a concepção de que os diferentes gêneros de poesia (épica, lírica, epigramática, epistolar, didática, satírica, etc.) obedecem a diferentes preceitos de composição, calcados em diferentes modelos literários antigos, que perfazem um repertório tradicional de potencialidades literárias a serem exploradas pelos novos autores. Assim, a métrica, o vocabulário, as idéias, as figuras, os lugares, os recursos retóricos e literários diferem de gênero para gênero, e limitam e definem o espaço de ação e criação do poeta posterior, que, por sua vez, estabelece seu texto como um interlocutor de um diálogo criativo e emulativo com o passado, e extrai desse diálogo intertextual os efeitos poéticos que deseja

${ }^{31}$ Cf. Matos, op. cit., p. 23. 
imprimir em seu próprio texto. Como as pesquisas mais recentes da área de estudos clássicos costumam ressaltar, não apenas a leitura das obras posteriores deve ser feita à luz da comparação com suas fontes, e ser interpretada, também, segundo essa óptica, mas a própria utilização de autores clássicos por autores tardios interfere na visão que nós temos dos clássicos, e alimenta com novos sentidos e novas possibilidades de leitura e compreensão as obras dos mais antigos, que são dessa maneira revitalizadas e adquirem novas texturas pela represenciação feita a posteriori.

Uma vez que os autores neolatinos assumem os parâmetros de composição literária dos clássicos, acabamos por observar que eles obedecem, claramente, aos princípios de diferenciação de gêneros literários defendidos pelos clássicos. Ao mesmo tempo, em parte por conta da larga influência da obra de Ovídio no período, eles são capazes de questionar esses limites, atenuá-los ou desafiá-los, como fez o poeta sulmonense, com tanta habilidade, em obras como "Heróides" (elegia em forma de epístola) ou "Arte de Amar" (misto de elegia amorosa e poesia didática), por exemplo.

De todo modo, considerando o papel atribuído aos princípios da "composição genérica", é fundamental, de antemão, separarmos os dois tipos de poesia composta por Antônio de Gouveia, pois lidamos com características específicas. Assim, a análise literária de sua obra ganha em clareza se, inicialmente, examinarmos em separado seus poemas, reunindo-os em dois grupos: os epigramas e as cartas poéticas.

Isso não significa que, num segundo movimento, não possamos estabelecer uma aproximação interpretativa entre essas duas obras, até porque elas foram publicadas na mesma época e, ademais, em 1540, no mesmo livro. Se notarmos que, às vezes, Gouveia usa o mesmo verso nas duas composições, e estabelece ele mesmo um diálogo intertextual (ou intratextual) entre ambas, veremos que é inevitável relacionarmos os dois textos; enfim, Gouveia faz alusões de uma obra na outra, e devemos enxergar essa rede alusiva.

Porém, num primeiro momento, defendemos, como meio de abordagem e ferramenta de interpretação, o exame em separado dos dois gêneros empregados por Gouveia. Com efeito, é preciso observar que o poeta português, assim como seus congêneres europeus, tinha plena consciência da importância do gênero na literatura clássica, e ele mesmo faz referência a isso, tanto nas cartas introdutórias do livro, quanto em alguns epigramas. Essa consciência se aplica e se reflete na escolha do metro, do vocabulário ou do tema, por exemplo.

Portanto, cabe adotar, de início, a separação entre os epigramas e as cartas, isto é, entre, de um lado, a poesia epigramática e, de outro lado, a poesia elegíaca sob a forma 
epistolar; isto feito, optamos por analisar, em primeiro lugar, a poesia epigramática, sobretudo por obediência à ordem de tempo e de edição em que o obra gouveiana foi originalmente publicada, mas também porque, sendo os epigramas muito mais variados e numerosos, permitem uma abordagem de múltiplos elementos que poderão ser posteriormente aplicados na leitura das cartas.

Em relação à poesia epigramática, como já vimos, ela se compõe de cerca de duas centenas de poemas, publicados em duas edições, nos anos subseqüentes de 1539 e 1540.

O volume de 1539 se compõe, em números exatos, de três cartas introdutórias, 105 epigramas e uma carta-posfácio.

O volume de 1540 se compõe de uma carta introdutória, um poema introdutório de 36 versos, 100 epigramas e uma carta-posfácio. Dos cem epigramas desta nova edição, 53 são inéditos e 47 são novas versões dos respectivos epigramas do ano anterior. Cabe lembrar que o mesmo volume de 1540 acolhe, após o fim do livro de epigramas, o livro das cartas poéticas, que se compõe, por sua vez, de duas cartas introdutórias em prosa, quatro cartas poéticas (com um total de exatamente 380 versos) e uma carta-posfácio em prosa.

No trabalho de exame dos epigramas, e, levando em consideração que o objetivo desta pesquisa é estudar os procedimentos de composição poética de Antônio de Gouveia e, sobretudo, como o próprio título da tese indica, a presença clássica nesse mesmo processo de composição, bem como em nosso processo de recepção e leitura da obra, pareceu-nos adequado, inicialmente, proceder a uma classificação dos epigramas, uma vez que eles formam um conjunto de mais de duas centenas de poemas (ou, pelo menos, 158 epigramas, se excluírmos os revisados e repetidos pelo autor).

Para fazer a classificação, achamos por bem adotar três critérios diferentes, que conduziram, por sua vez, a três classificações diversas, que podem ser associadas e acumuladas para esquadrinhar de modo mais minucioso cada epigrama.

Como o principal foco de nossa investigação é a análise dos princípios de composição literária utilizados por Gouveia, na primeira classificação interpretativa dos epigramas adotamos, como parâmetro, justamente o tipo de procedimento que levou à composição de cada epigrama. Trabalharemos, nesse sentido, com as seguintes categorias: em primeiro lugar, epigramas que são versões para o latim de poemas originalmente compostos em outras línguas (no caso de Gouveia, epigramas em grego e em francês); em segundo lugar, epigramas assentados sobretudo num diálogo de referências intertextuais com fontes clássicas; em terceiro lugar, as criações próprias de Gouveia, cujo ponto de partida não reside num texto 
específico (ou, admitamos, num texto que tenha sido possível identificar em nossos estudos) que foi ou traduzido ou emulado, mas antes num respeito, durante a fase de criação, pelas normas de composição clássicas, aplicadas segundo os gêneros poéticos da Antiguidade.

Assim, temos três possibilidades de princípio de composição: a tradução, a paródia e, por último, a criação livre, respeitadas, neste terceiro caso, as regras genéricas clássicas.

Em relação ao segundo tipo de composição, a paródia, o que pretendemos enfocar, com essa classificação, é um tipo de poema que foi nitidamente composto a partir de uma alusão ou diálogo com uma fonte do passado, e para cuja leitura é imprescindível a identificação da fonte. Assim, neles a alusão paródica não é acidental nem ornamental, mas essencial, e estabelece a própria formação do poema, que busca, primordialmente, comentar, retrucar, desenvolver, refazer ou redefinir o texto original. Em comparação com a paródia, o terceiro tipo de epigrama é autônomo, pois não se assenta nem num poema que foi vertido nem num trecho poético que foi comentado ou manipulado por Gouveia. Isso não quer dizer que esse terceiro tipo de poema não proponha jogos intertextuais. Afirmar isso seria completamente incorreto, uma vez que, com muita frequiência, Gouveia faz uso de citações e alusões nos mais diversos epigramas.

Aplicando esse critério aos dois volumes de epigramas de Gouveia, chegamos aos seguintes números:

\section{Em 1539:}

a) traduções: 9 (2 do grego e 7 do francês); ${ }^{32}$

b) paródias identificadas: $6 ;^{33}$

c) composições genéricas livres: 90 .

Em 1540:

a) traduções: 9 (3 do grego e 6 do francês); ${ }^{34}$

b) paródias identificadas: $5 ;^{35}$

\footnotetext{
${ }^{32}$ São traduções os epigramas, em 1539: Livro I: 9, 12, 17, 26, 32, 58, 63; Livro II: 3, 12.

${ }^{33}$ São paródias, em 1540: Livro I: 4, 28, 60, 64; Livro II: 9, 27.

${ }^{34}$ Em 1540, são traduções os epigramas 13, 15, 31, 32, 61, 66, 70, 72, 95.
} 
c) composições genéricas livres: 86 .

Os epigramas de Antônio de Gouveia também podem ser classificados de acordo com os subgêneros temáticos da poesia epigramática clássica, isto é, adotando como critério o objeto temático de cada peça. Essa tipologia segundo o aspecto temático permeia, por exemplo, a Antologia Grega, cujos volumes se encontram distribuídos conforme esse critério. Após a leitura da obra gouveiana, concluímos que é possível separar os poemas em quatro grupos: laudatórios; sepulcrais; amorosos; e jocosos; estes últimos ocupam a maior parte da obra, com pouco mais de metade das composições.

No volume de 1539, os 105 epigramas podem ser assim divididos:
a) laudatórios: 11,36
b) sepulcrais: $9 ;^{37}$
c) amorosos: $21 ;^{38}$
d) jocosos: 64;

TOTAL: 105 .

No volume de 1540, os 100 epigramas podem ser assim divididos:
a) laudatórios: $16,3^{39}$
b) sepulcrais: $16 ;^{40}$
c) amorosos: $13 ;^{41}$
d) jocosos: 55;

TOTAL: 100 .

\footnotetext{
${ }^{35}$ Em 1540, são paródias os epigramas 6, 34, 62, 68 e 80.

${ }^{36}$ Os epigramas laudatórios de 1539 são: 8, 26, 27, 34, 52, 58 (livro I); 5, 14, 15, 18, 40 (livro II).

${ }^{37}$ Os epigramas sepulcrais de 1539 são: 5, 9, 54, 62 (livro I); 6, 11, 24, 30, 38 (livro II).

${ }^{38}$ Os epigramas amorosos de 1539 são: 1, 12, 17, 23, 32, 35, 36, 40, 49, 53, 56, 63 (livro I); 1, 3, 4, 13,
} 17, 21, 28, 33, 39 (livro II).

\footnotetext{
${ }^{39}$ Os epigramas laudatórios de 1540 são: 4, 10, 22, 27, 31, 32, 39, 41, 49, 58, 65, 71, 76, 89, 92, 93.

${ }^{40}$ Os epigramas sepulcrais de 1540 são: 7, 11, 13, 17, 20, 29, 43, 53, 56, 67, 72, 77, 78, 82, 87, 95.

${ }^{41}$ Os epigramas amorosos de 1540 são: 2, 15, 37, 51, 55, 59, 61, 64, 66, 69, 74, 94, 96.
} 
Reconhecemos, entretanto, que a classificação esbarrou em dificuldades, para as quais apresentamos soluções porventura questionáveis. Alguns exemplos dos problemas enfrentados são mencionados a seguir. Em primeiro lugar, é de notar que alguns epigramas têm um título que presta evidente homenagem ao destinatário, ainda que seu conteúdo seja, por exemplo, jocoso. Nesses casos, embora o título induza a considerá-lo um epigrama laudatório (e, certamente, o contexto nos autorize essa classificação), privilegiamos a classificação segundo o conteúdo e o tema do poema (e, nesses casos, prevaleceu a tipologia de acordo com o texto da peça). Em segundo lugar, constituindo um caso à parte, devemos mencionar os poemas amorosos dedicados a Catherine; com efeito, muitos dos poemas são peças nitidamente laudatórias, entoando loas à mulher amada, elevando-a e, por vezes, divinizando-a. Neste caso, ainda que as composições se prestem a elogiar Catherine, consideramos que os poemas são declarações de amor, sempre destinadas à mulher amada e, conseqüentemente, estão mais bem agrupados e são mais adequadamente compreendidos se figurarem entre os poemas amorosos. Em terceiro lugar, existem muitos epigramas que podem ser considerados mistos, pois apresentam características de mais de uma categoria. Podemos citar como exemplos mais nítidos disso os seguintes poemas: em 1539, no livro I, os epigramas 6, 21, 22 e 60 (os quatro são mistos de jocoso e laudatório); ou o epigrama 35 (misto de amoroso e jocoso). Em 1540, os epigramas 24 e 71 (misto de jocoso e laudatório); 37 e 94 (misto de amoroso e sepulcral); 52 (misto de jocoso e amoroso).

Embora esses poemas mistos deponham contra a tentativa de elaborar uma classificação estanque da poesia epigramática de Gouveia, ainda assim consideramos mais produtivo manter a classificação em quatro categorias de composição, pois ela auxilia na compreensão geral da obra e facilita a abordagem individual das composições.

Em três dessas quatro grandes categorias temáticas, podemos, ainda, fazer uma série de subdivisões úteis para perceber, de modo mais minucioso, a temática dos poemas e os procedimentos poéticos de Gouveia.

No caso dos poemas laudatórios, porém, a homogeneidade do estilo nos levou a considerá-los, desse ponto de vista, como um todo indivisível, já que todos se destinam a promover o elogio do destinatário do poema, que tanto pode ser um rei ou nobre quanto poetas e humanistas. Assim, a proposta de subdivisões não se aplicará a eles.

Em relação aos poemas sepulcrais, uma importante subdivisão se dá entre os epigramas que se exibem como verdadeiros epitáfios e aqueles que, embora versando sobre o 
tema da morte, se apresentam de maneira diferente, privilegiando, neste caso, ou uma narrativa da hora da morte, ou uma composição assentada em descrições mitológicas, ou uma reflexão sobre o fim da vida, etc. Mas é preciso que fique claro: não se quer dizer, aqui, que os poemas do segundo subtipo não possam ser epitáfios, pois, de fato, eles podem ser compreendidos como um outro estilo de compor uma placa fúnebre; o que queremos dizer, simplesmente, é que os epigramas do primeiro subtipo obedecem a um padrão mais tradicional de compor um epitáfio, apresentam-se como autênticas placas fúnebres, sugerindo fictivamente sua aposição a um túmulo e, finalmente, foram concebidos dessa maneira pelo poeta, que, para realçar essa característica, editou tais poemas, em 1540, com letras maiúsculas, dando a entender que notava e enfatizava a diferença entre os dois subtipos.

Quanto aos poemas amorosos, podemos separá-los em três grupos: aqueles que, dedicados a Catherine, procuram enaltecê-la, tomando-a como tema do próprio epigrama; aqueles que, embora dedicados a ela, falam principalmente da sensação amorosa experimentada pelo poeta; e aqueles que tomam o amor como assunto do epigrama, podendo envolver referência à mitologia, ou à amada de Petrarca, Laura, por exemplo; é de notar que os dois primeiros subtipos de epigrama amoroso se aproximam entre si, na medida em que ambos funcionam como declarações de amor a Catherine.

Finalmente, no caso dos poemas jocosos, antes de apresentar os diferentes subtipos, é necessário um esclarecimento: optamos por englobar nessa categoria um conjunto amplo de temáticas, e não apenas os poemas de tom puramente satírico ou que se prestam a um ataque, vitupério ou piada sobre determinado sujeito ou vício; além desses, há poemas de caráter metapoético e até mesmo filosóficos, reflexivos ou de matiz religioso. O que nos levou a reuni-los numa única e abrangente categoria foi, principalmente, a maneira leve com que os temas foram abordados, o caráter intencional de "nuga ou ninharia" da composição, segundo uma tradição clássica cujo expoente é Marcial, e, ainda mais, a impossibilidade de enquadrálos nas categorias anteriores. Mas se deve atentar para o fato de que os poemas dessa categoria, embora leves no modo de composição e apresentação, podem tratar de assuntos graves e rebuscados. Em suma, a categoria de epigrama jocoso, em contraste com a de poema laudatório ou panegírico, apresenta uma grande heterogeneidade.

Isto posto, podemos fazer as seguintes distinções entre os epigramas jocosos de Gouveia: a) aqueles que poderíamos denominar morais ou satíricos, pois atacam precipuamente um vício moral ou um defeito de caráter do destinatário, como o egoísmo, a soberba, a gula ou o amor da bebida; b) aqueles que atacam a qualidade das obras de poetas 
ou humanistas; c) aqueles que são autocríticos ou metapoéticos e têm, por vezes, caráter programático e fazem uma reflexão sobre os próprios epigramas ou a própria obra de Gouveia; e d) aqueles que tematizam assuntos menores ou cotidianos, ou, diferentemente, tratam de assuntos profundos, mas de forma leve e num estilo ligeiro, cabendo ainda, neste subgrupo, epigramas que não passam de um pequeno chiste, às vezes construído sobre um trocadilho ou um jogo de palavras despretensioso.

Além das duas classificações acima propostas, cabe ainda a possibilidade de agrupálos e classificá-los por pertencerem ou não a verdadeiras correntes ou ciclos de poemas, uma vez que diferentes epigramas retomam um mesmo modo de tratamento de determinado assunto ou uma mesma referência específica, tecendo uma rede de composições organizada por alusões intratextuais.

Essas referências constitutivas de subgrupos podem ser expressas: a) por títulos semelhantes $^{42}$; b) por um mesmo destinatário ${ }^{43}$; c) pelo uso de um mesmo lugar-comum ${ }^{44}$; d) pela abordagem de um mesmo subtema ${ }^{45}$; e) pela retomada de vocábulos específicos ${ }^{46}$; f) pelo uso de um mesmo recurso literário ou retórico ${ }^{47}$.

Alguns exemplos dessas "cadeias", "séries" ou "seções poéticas", configuradas segundo os elementos expostos acima, serão analisadas e comentadas a seguir.

Tendo sido feitas as classificações e quantificações acima, a fim de, por um lado, dar uma visão sinóptica da obra epigramática de Antônio de Gouveia e, por outro lado, conhecer,

${ }^{42}$ Por exemplo, cadeias de epigramas “Ad Catharinam Bofremontanam”, ou “Ad Andraeam Fratrem”, ou “Ad Zebedaeum”, ou “Ad Lectorem", ou ainda "Memoriae Sempiternae".

${ }^{43}$ Por exemplo, ciclos de epigramas dedicados a Étienne Dolet, ou a Diogo de Teive, ou a Jacques de Beaune, além dos mencionados acima, a Catherine ou a André de Gouveia.

${ }^{44}$ Por exemplo, as redes de epigramas sobre o tópico do túmulo exíguo, ou sobre o tópico da brevidade do livrinho, ou sobre a efemeridade/permanência da fama.

${ }^{45}$ Por exemplo, cadeias de epigramas sobre o vício da bebida, ou sobre a falsa religiosidade.

${ }^{46}$ Por exemplo, ciclos de epigramas que utilizam a palavra "libellus", ou "nobilitas", ou "lepus", ou "nugae", ou "archipoeta".

${ }^{47}$ Por exemplo, a rede de epigramas formada pela figura da preterição. 
numa primeira abordagem, o teor e as características dos seus epigramas, passaremos agora a analisar exemplos de cada uma das categorias poéticas apontadas acima, para identificar mais claramente os elementos que constituem os poemas, verificar a presença clássica na obra de Gouveia e compreender seu estilo próprio de composição.

Seguindo a ordem anteriormente apresentada, comecemos as análises com as traduções feitas para o latim de poemas franceses e gregos. Selecionamos dois epigramas, um originário do francês e outro do grego. As duas composições revelam influências sobre Gouveia e indicam sua inserção no movimento renascentista francês.

Cabe lembrar, antes de tudo, que a própria prática de verter poemas era corrente entre os poetas neolatinos, que, nesse ponto, imitavam um procedimento de Ausônio, o poeta bordalês que foi uma das grandes inspirações dos humanistas franceses.

Em primeiro lugar, analisemos a versão latina elaborada por Gouveia para uma “décima” escrita por Clément Marot, um dos mais importantes poetas da França renascentista no século XVI. Marot participou ativamente do círculo literário humanista de Lyon e tinha contato com poetas como Bourbon, Visagier ou Ducher, que imitaram suas composições. Seu primeiro editor foi Étienne Dolet (justamente um autor muito referido por Gouveia, de quem era íntimo), com quem Marot viria a se desentender visceralmente. O poema, também publicado com o título "Le dixain de neige", é o seguinte (Primeiro Livro de Epigramas, XXIV):

\section{D’ ANNE, QUI LUY JECTA DE LA NEIGE}

Anne (par jeu) me jecta de la Neige,

Que je cuidoys froide certainement:

Mais c'estoit feu: l'experience en ay je,

Car embrasé je fuz soubdainement.

Puis que le feu loge secrettement

Dedans la Neige, où trouveray je place

Pour n'ardre point? Anne, ta seulle grâce

Estaindre peult le feu que je sens bien,

Non point par eau, par neige, ne par glace,

Mais par sentir un feu pareil au mien. 
As formas dos vocábulos do poema, em francês antigo, não são muito distantes do francês atual, o que permite a sua aproximação com as formas contemporâneas, sem grande dificuldade, com exceção, talvez, de "Estraindre", forma arcaica do verbo "éteindre" ("extinguir") e "cuydois", forma arcaica do imperfeito do verbo "cuyder", que não é mais corrente nos dias de hoje, mas que era empregado com freqüência na poesia medieval e renascentista, no sentido de "acreditar falsamente", “imaginar". Há inúmeros exemplos em Marot do emprego desse verbo. Em português, o verbo "cuidar" ainda retém o significado de “supor, julgar", revelador, aliás, do étimo "cogitare".

Gouveia fez duas versões desse poema. Embora a comparação entre as edições de 1539 e 1540 não seja o propósito deste capítulo da tese, as diferenças entre as composições dos anos consecutivos são significativas demais para serem ignoradas. Por isso, optamos por analisar as duas formas de cada epigrama, procedimento que repetiremos no que concerne à tradução do grego.

Em relação ao epigrama vertido do francês, em 1539, Gouveia manteve o número de versos, no total de dez, dispostos em cinco dísticos elegíacos. Já na versão de 1540 , ele se distanciou do poema original, não apenas no número de versos, que reduziu a seis, mas no próprio conteúdo da composição, que adaptou de maneira mais livre, embora retendo o cerne do francês.

Vejamos os poemas; primeiro, o de 1539 (Epigr. I, 12):

\section{AD CATHARINAM BOFREMONTANAM \\ E Gallicis Marotti}

Me niue candenti petiit Catharina: putabam

Igne carere niuem: nix tamen ignis erat.

Non est uana fides, non experientia fallax:

Sensi etenim subitis corda cremata rogis.

Ergo ubi tutus ero, niuibus si conditur ardor,

Effugiamque tuas, saeue Cupido, faces?

$\mathrm{Tu}$, Catharina, potes subitas extinguere flammas,

Non glacie, aut niuibus, marmoreis uel aquis.

Sed si quae patior, poenae quoque sentiat autor:

Et nostrum flamma flagret uterque pari. 
A seguir, a versão de 1540 (Epigr. 15):

\section{CATHARINAE}

\section{E Gallicis Clementis Marotti}

Dum Catharina petis niue me candente, putabam

Igne carere niuem, nix tamen ignis erat.

En, quid agam, fallax niuibus si conditur ardor,

Si latet adstricta frigus, et ignis aqua?

An, Catharina, meo uiuit quae in corde fauilla,

Crescit frigoribus, uincitur igne pari?

$\mathrm{Na}$ versão de 1539, percebe-se que Gouveia procurou ser fiel ao texto de Marot, transpondo para o latim cada verso do francês. Diante das escolhas do humanista português, especialmente por construções sintáticas muito concisas no latim, foi necessário fazer algumas compensações, alongando propositadamente certos versos latinos, para manter a equivalência pretendida. Por exemplo: os dois primeiros versos franceses ocupam apenas um verso e meio no latim; para compensar isso, Gouveia transforma o hemistíquio "l'experience en ay je" num verso inteiro, "Non est uana fides, non experientia fallax". A mesma tática é repetida no sexto verso latino, uma reiteração do que já estava no quinto verso, servindo apenas para manter a equivalência entre as versões. Como Gouveia condensa, no sétimo verso, o conteúdo do sétimo e do oitavo versos do francês, foi preciso usar do mesmo recurso e dilatar o conteúdo do décimo verso do francês, que ocupa os versos 9 e 10 do latim, garantindo, afinal, o mesmo número de versos e o andamento pari passu. Note-se que a palavra marmoreis, no oitavo verso, também tem a mesma razão de ser, e funciona como uma cunha, garantindo a reprodução de um verso francês completo (o nono, "Non point par eau, par neige ne par glace") por um verso completo no latim.

Além disso, nota-se em Gouveia uma tendência ambivalente: por um lado, ele respeita a concepção clássica do dístico elegíaco, como unidade funcional, autônoma e episódica do poema: o terceiro, o quarto e o quinto dísticos, que formam períodos completos em si, e traduzem idéias independentes, mostram nitidamente a forma de construção. Mas, por outro lado, ele elabora frases agudas e sentenciosas, células menores dentro do dístico: veja-se, a 
título de exemplo, a frase independente que encerra o primeiro dístico: "nix tamen ignis erat". É essa linha de construção que leva o poeta a repetir em 1540 alguns cola da versão anterior, independente da extensão do poema, caso da frase recém-citada e também de outras, como "putabam igne carere niuem" ou "niuibus si conditur ardor".

Ao abandonar, em 1540, a preocupação com a equivalência exata no número de versos, Gouveia permitiu-se usar magistralmente da concisão proporcionada pela sintaxe da língua latina e, ao mesmo tempo, ficar à distância do sentido mais estrito do texto francês, para propor um desenvolvimento e especialmente um desfecho diferente ao poema, não mais focado na mulher amada, como faz Marot, mas sim focado no próprio jogo de palavras e pensamentos antitéticos. É como se a nova versão de Gouveia fosse mais intelectual e menos sentimental. Ao mesmo tempo, ele elabora mais detidamente e enfoca mais de perto um jogo de paradoxos, desde o primeiro até o último verso (e.g. desde "neve que queima" [niue candente] até "chama que cresce com o frio e é vencida por um fogo igual [fauilla (quae) crescit frigoribus, uincitur igne pari]), jogo esse devido a Petrarca; ou seja, Gouveia se afasta de Marot para se voltar para a concepção petrarquista, de que o poema francês, aliás, é inteiramente tributário.

Dentre os aspectos que mostram que Gouveia não pretende uma tradução servil do poema francês, mas deseja antes apropriar-se da composição francesa para explorar, no latim, os recursos peculiares desta língua, ou seja, dentre os dados que indicam o afastamento de Gouveia em relação ao texto estrito de Marot, podemos citar três elementos: a multiplicidade de sinônimos em latim usada por Gouveia para verter a palavra "feu" (ignis, rogus, ardor, faces, flamma, e ainda, na versão de 1540, fauilla); o uso do "tu" desde o primeiro verso; e a simplificação obtida, em 1540, graças à interrogativa "quid agam", que resume o equivalente a um verso inteiro do original.

Essa liberdade de Gouveia, radicalizada em 1540, é elemento constituinte de todas as versões realizadas pelo humanista, e devemos compreender que ele pretendia, de fato, uma tradução criativa, mais próxima de uma adaptação, do que a simples transposição para o latim de poemas compostos em outras línguas. Diferente de exibir um mero exercício escolar de versão, Gouveia quis marcar sua capacidade poética na língua latina; não por acaso essas versões fazem parte (e uma reduzida parte, aliás) de um livro de composições próprias. Ademais, o movimento no sentido de libertar-se mais frouxamente dos originais é próprio das versões de 1540, que, diferentemente das versões de 1539, não respeitam a estrofação (isto é, o número de versos) dos poemas franceses. 
Vejamos a confirmação dessa análise com a versão em latim de uma inscrição grega. Trata-se do epitáfio de Lucila, encontrado na cidade de Bordeaux no século XVI e considerado autêntico por humanistas da época. Ele consta de antologias arqueológicas de inscrições lapidares, e figura na edição da Antologia Palatina, no volume intitulado Anthologiae Graecae Appendicis, caput II (Epigrammata Sepulcralia), sob o número 537.

Todas as referências renascentistas a essa pedra tomam como base um depoimento do humanista francês Élie Vinet, que declarou existir em Bordeaux, no interior da Catedral de Santo André, uma pedra tumular com esse epitáfio antigo, lavrado em grego. Com efeito, esse humanista e editor, ao publicar a obra completa de Ausônio, incluiu alguns capítulos de comentários, entre os quais um intitulado "Elias Vinetus In Ausonii Vrbes". Nesse capítulo, ao referir-se a monumentos antigos de Bordeaux, resquícios da Antigüidade, ele acrescenta o registro dessa lápide, já então desaparecida. A partir daí, o próprio Vinet fez uma versão latina do referido epigrama, e anotou uma série de outras versões compostas por humanistas do período, dentre as quais a proposta de Gouveia. Percebe-se, por seu depoimento, que a inscrição atraiu grande atenção, e houve mesmo um concurso, entre os intelectuais renascentistas, para apresentar a versão considerada mais elegante.

O texto do epigrama é o seguinte:

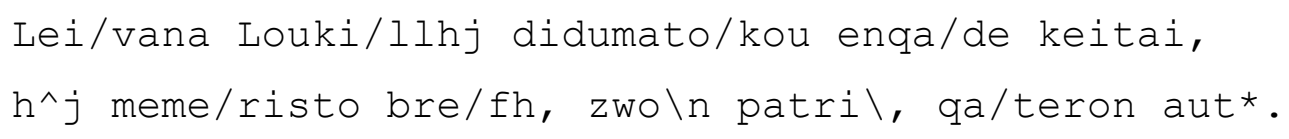

As duas diferentes versões de Gouveia são as seguintes, começando pela de 1539 (epigr. I, 9):

\section{M. LVCILLAE}

E Graeco Vetustissimo

Hoc tumulo, Lucilla, iaces enixa gemellos.

Ille patri superest: est comes ille tuus.

A versão de 1540 é esta (epigr. 13): 


\section{M. LVCILLAE}

Quos uno geminos partu, Lucilla, dedisti,

Cernitur officio functus uterque suo.

Ille Patris lacrymas miseri solatur, et ille

Optauit tecum, sustinuitque mori.

Como adiantamos, ocorre com ele o mesmo fenômeno observado na tradução de Marot: a versão de 1539 é mais próxima do original, ao passo que a de 1540 é mais livre, na forma e no conteúdo, sendo mais longa e mais rebuscada que o original. Uma transformação comum a ambas as versões, no entanto, é a de utilizar Lucila como vocativo, e dirigir-se a ela em segunda pessoa, em contraste com o texto original, em que "Loukílles" (Lucila) está no genitivo, qualificando "leípsana" (ao pé da letra, "os restos mortais de Lucila”).

Tirando essa adaptação, o poema de Gouveia, em 1539, é muito próximo do original, pelo menos nos seguintes aspectos: a) mesmo número de versos; b) mesma distribuição de conteúdo nos dois versos, isto é, o primeiro verso trata de Lucila, que gerou gêmeos, enquanto o segundo trata do destino dos filhos; c) há uma correspondência muito nítida entre os termos gregos e os latinos do primeiro verso; por exemplo, iaces $=($ retoma $)$ keitai, enixa gemellos $=$ didymatokou, Lucilla = Loukílles, hoc tumulo = enthade; d) no segundo verso, a correspondência não é tão flagrante, com exceção de "patri”" (homônimos em grego e latim), e do eco "tuus" = "autei"; mas a distribuição dos sintagmas e das orações no interior do verso se aproxima muito do original, e respeita a idéia presente no grego; por exemplo, a separação entre os dois filhos, marcada no grego pelo termo memeristo, é pontuada no latim pelo uso redobrado de ille; em seguida, no grego, fala-se primeiro do filho vivo, para encerrar o verso com a menção ao filho morto; a mesma ordem foi seguida no latim, onde, graças ao uso do pentâmetro, o afastamento dos filhos fica acentuado pela diérese principal e pela divisão dos hemistíquios.

Em que pese tal respeito pelo poema original, Gouveia foi capaz de imprimir sua marca própria de criatividade em alguns detalhes. Primeiro, note-se a assonância em "es" que aparece em três palavras seguidas (superest, est, comes): além do efeito sonoro, o eco do homeoteleuto "superest / est" suaviza a cesura e permite uma passagem harmoniosa do primeiro para o segundo hemistíquio do pentâmetro. Assim, enquanto o redobro do ille acentua a diferença de destinos, a sonoridade aponta para a ligação consangüínea dos irmãos, 
para a sua geminação. Gouveia também configurou, com habilidade, a simetria em dupla do epigrama: de um lado, a duplicidade proveniente da nítida separação entre primeiro e segundo verso; de outro, a proveniente da separação entre os dois hemistíquios do segundo verso, cada um deles relacionado com um dos filhos.

A versão de 1540, como já dito, é muito mais livre em relação ao original. Nessa linha, chama a atenção o fato de que o humanista retirou, nesse ano, o subtítulo do poema, que declarava sua vinculação a um texto anterior em idioma grego (e graeco uetustissimo): agindo assim, Gouveia parece rejeitar o rótulo de tradução para sua composição.

Além dessa omissão, Gouveia dobra o número de versos do epigrama original e de sua versão anterior, passando a quatro, distribuídos em dois dísticos elegíacos. A nova versão parece mais uma reelaboração de seu próprio epigrama do que uma refacção da tradução sobre o epitáfio original. Ainda assim, pelo menos um termo remete diretamente ao original grego, inexistindo na versão de 1539: trata-se de cernitur, que retoma, ao menos semanticamente, memeristo.

O mais evidente, porém, é a retomada da estrutura assinalada pelo redobro de ille. Gouveia manteve a idéia, mas distende as reflexões (e as frases) relativas a cada um dos pronomes ille, que passam ocupar um verso inteiro, e não mais meio verso. Esse prolongamento é estranho ao original e à versão de 1539: neles, usava-se apenas duas palavras (zwon patri) ou três (ille patri superest). Agora são cinco palavras (ille Patris lacrimas miseri solatur), e a mesma multiplicação se dá com os termos referentes ao segundo filho, o falecido. Essa distensão é fruto exclusivo da composição gouveiana. A mesma interferência do humanista lusitano aparece no segundo verso, cernitur officio functus uterque suo. Essa interpolação, que guarda certa ressonância da mesma expressão sintagmática utilizada no verso 4 do epigrama 8 (Fungitur officio nostra Thalia suo) ${ }^{48}$, mostra o desejo gouveiano de, a partir de um mote dado por um termo grego, cunhar um verso que fosse belo em si, tanto pela correção gramatical e métrica quanto pela sonoridade plena de aliterações e assonâncias. De certa forma, foi o prolongamento do segundo verso do poema que obrigou Gouveia a criar mais um dístico, e preenchê-lo de acordo com a simetria do original, mas com uma carga semântica antes inexistente ou, no máximo, subentendida. Na elocução do dístico final,

${ }^{48}$ O poema completo e sua tradução se encontram na parte destinada à edição do texto poético de Gouveia. Não o reproduzimos aqui porque não identificamos uma correspondência de significado com o epigrama sepulcral ora analisado. 
evidencia-se um vocabulário compartilhado com as cartas poéticas, mostrando que seu repertório encaminhava-se do gênero epigramático para o elegíaco.

A análise das duas traduções selecionadas de Gouveia contempla uma série de características comuns e permite, desde já, avançar algumas conclusões acerca das motivações e das opções estilísticas do poeta.

Em primeiro lugar, patenteia-se seu envolvimento com o movimento humanista e seu engajamento ativo na poética neolatinista de sua época. Com efeito, a primeira tradução analisada é a proposta de versão para o latim de um poema de um dos mais importantes poetas franceses da Renascença, residente na mesma Lyon onde se encontrava Gouveia; esse poema, por sua vez, traz elementos muito marcantes de um petrarquismo literário que dominou a produção poética dos séculos XV e XVI; e ainda podemos acrescentar que outras versões desse mesmo poema, ou outros poemas de teor muito semelhante, foram compostos por neolatinistas europeus. A segunda tradução, por sua vez, revela seu vínculo com o círculo humanista de Bordeaux, onde viveu por muitos anos; é uma proposta de versão para o latim de um epitáfio grego, conforme praticava o poeta bordalês Ausônio, idolatrado naquela região da França; compete e rivaliza com várias outras versões apresentadas naqueles anos; faz referência e homenagem a um monumento do mundo helenístico encontrado em terras francesas; permite a Gouveia pôr-se ao lado de um movimento de resgate, recuperação e revalorização de resquícios da cultura clássica; e propicia ao poeta, enfim, revelar um apurado domínio do grego, cujo conhecimento o colocava na vanguarda intelectual do período.

Em segundo lugar, a própria proposta de fazer versões para o latim já indica uma opção estética muito peculiar da época, e, por outro lado, uma declaração muito assertiva de filiação num passado clássico, de onde o humanista extrai seu repertório, vocabulário, princípios e preceitos.

Em terceiro lugar, elas revelam o interesse, por parte de Gouveia, de ser muito mais do que simples versejador latino, e de não submeter seu próprio texto aos poemas que verte, mas, antes pelo contrário, o de expor deliberadamente sua veia poética, que pode encontrar vazão inclusive na tradução poética. Assim, a tradução, sobretudo em 1540, é um espaço e uma oportunidade para mostrar aos colegas renascentistas seus dotes poéticos e seu domínio da língua latina.

Em quarto lugar, as composições resultantes mostram preocupações com a sonoridade, com a simetria da composição, com o respeito pela forma e pelas normas do dístico elegíaco, 
com a criação de versos singulares ricos de elementos poéticos clássicos e com o melhor uso de recursos literários e retóricos.

Em quinto lugar, a presença clássica nesse tipo de composição (a tradução) está duplamente assegurada e visível: seja por si mesma e diretamente, na medida em que os poemas reutilizam e revitalizam os elementos de composição literária dos antigos; seja indiretamente, ao se apoiarem num ambiente cultural, ao se remeterem a uma estética literária e ao se referirem a obras poéticas de caráter renascentista que evocavam e recuperavam, em segunda mão, esses mesmos elementos clássicos.

Tendo visto como Gouveia elabora suas traduções, passemos a outro tipo importante de composição no seio da obra do humanista português, a paródia, entendida aqui como uma composição poética que fundamentalmente dialoga com um poema clássico latino e que deve ser compreendida a partir desse diálogo, pois o valor e o sabor do epigrama provém dos efeitos obtidos a partir dessa rede intertextual, e do reconhecimento, pelo leitor, dessa ponte literária.

Neste caso das composições paródicas (excluindo as cartas poéticas, que têm muito desse perfil, mas serão tratadas a seguir), selecionamos inicialmente o epigrama dedicado a Ausônio, pois a composição gouveiana não apenas propõe um diálogo com o epigrama ausoniano, mas verdadeiramente rebate a proposição do poeta francês, interferindo na recepção dos conceitos presentes no poema original. É nisso que residiria, nos círculos humanísticos do Renascimento e entre os leitores eruditos, a graça do epigrama.

Mas passemos ao epigrama dedicado a Ausônio, para que se verifique a que nos referimos. Em 1539, ele é o epigrama I, 4.

\section{AD AVSONIVM}

Salua tibi ueterum maneat modo regula morum,

Ludat, ais, mixtis sobria Musa iocis.

At ueterum pereat quamuis mihi regula morum,

Sordidulos fugiet pagina nostra iocos.

Namque satis fuerit caste uixisse tacentem: 
Scribenti non est uita pudica satis.

Na versão de 1540, a seguir, ele é o epigrama 6:

\section{AVSONIO POETAE BVRDIGALENSI}

Salua tibi ueterum maneat modo regula morum,

Ludat, ais, mixtis sobria Musa iocis.

Casta quidem Ausonio fuerit sat uita, poetae,

Non fuerit morum regula prisca satis.

Algumas informações prévias são primordiais para permitir uma adequada compreensão e fruição do poema. Em primeiro lugar, cabe relembrar que Ausônio, poeta natural de Burdigala, atual Bordeaux, na França, no século IV d.C., foi um grande modelo dos poetas neolatinos franceses, e um dos grandes vultos à sombra dos quais floresceu a Renascença francesa. Se Ausônio, no século XVI, era cultuado e reverenciado no mais alto grau, em toda a França, isso ocorria ainda mais em Bordeaux. E Gouveia, como dito acima, morou por cerca de cinco anos nessa cidade, entre 1534 e 1538, aproximadamente. Nessa mesma cidade, seu irmão André de Gouveia dirigia o importante Colégio da Guiena (Collège de Guienne), fundado nos moldes do Collège de France.

Ausônio era, portanto, o grande clássico francês, o notável predecessor da Plêiade, o insuperável escritor bordalês. Assim, os neolatinos franceses procuravam imitar as características poéticas de Ausônio: admiravam sua versatilidade, sua fecundidade, sua renovação da literatura latina, sua capacidade de diálogo intertextual com os clássicos. Também imitavam seus modos de composição: ele fizera versões latinas de epigramas gregos, e isso passou a ser moda entre os neolatinos (e já vimos, acima, que Gouveia também seguiu a corrente); fizera epigramas dos mais diversos subgêneros, e também nisso foi imitado. $\mathrm{O}$ estilo de Gouveia, portanto, recebeu clara influência de Ausônio. Não é de estranhar, assim, que um dos primeiros epigramas do livro do poeta português faça um tributo ao bordalês.

O poema se apóia numa citação de Ausônio: de fato, os dois primeiros versos do epigrama de Gouveia reproduzem, com pequenas adaptações (requeridas ou pelo sentido ou 
pela métrica), os dois últimos versos de um dos mais conhecidos epigramas de Ausônio, aquele que, na abertura de sua obra epigramática, lança, programaticamente, os princípios estilísticos de sua atividade; em outras palavras: o epigrama de Gouveia, que irá desconstruir a proposição de Ausônio, tem o dístico inicial correspondente ao dístico conclusivo de sua fonte.

O dístico original composto por Ausônio é o seguinte:

Salua mihi ueterum maneat dum regula morum

Ludat permixtis sobria Musa iocis.

Antes de prosseguirmos na análise, é necessário expor um pequeno comentário de caráter filológico: na verdade, tanto a posição quanto o texto do epigrama são polêmicos. Hugh Evelyn-White, na publicação que serviu de parâmetro para as edições de Ausônio durante quase todo o século XX, publicada no bojo da Loeb Classical Library, atribuiu ao poema o número 25, no miolo do conjunto de epigramas, colocando-o como primeira composição da segunda seção, sob o título "Commendatio Codicis". Em relação ao verso final, Evelyn-White registra "permissis" em lugar de "permixt is".

Green, no mais recente trabalho de edição das obras completas de Ausônio, publicado por Cambridge, coloca-o no primeiro lugar de todo o conjunto de epigramas, e faz algumas transposições e correções nos versos iniciais. Quanto ao verso final, defende a leitura de "permissis", por motivos estilísticos e por encontrar essa forma nos códices, embora ressalve que algumas edições tragam a palavra "permixtis".

Tivemos acesso a uma edição bordalesa, do início do século XVII, da obra de Ausônio. Nesse volume, o referido epigrama não é o primeiro, mas o segundo do corpus, e registra a palavra "permistis", e não a forma "permissis" defendida atualmente. Cabe notar, ainda, que o início do epigrama é diferente da versão proposta pelos editores atuais. De todo modo, Gouveia certamente teve acesso a uma edição francesa semelhante a esta por nós encontrada, e foi baseado nela que citou os versos de Ausônio, apenas adaptando o vocábulo "permixtis" para "mixtis", em função da métrica e da introdução do verbo "ais".

Não nos sendo possível detalhar os critérios que nortearam cada uma das propostas de leitura filológica, preferimos reproduzir acima apenas os dois versos finais do poema de Ausônio (de acordo com a edição provavelmente lida por Gouveia), até porque a alusão do humanista português se prende diretamente a eles. 
Além dessa questão filológica, cabe também observar que a diferenciação feita por Ausônio, entre autor e obra, ou seja, entre a moralidade que cabe ao autor e as liberdades concedidas à obra, é anterior na literatura clássica, e vamos encontrá-la, por exemplo, em Marcial, que sustentava, no epigrama I, 4, verso 8:

Lasciva est nobis pagina, vita proba.

O mesmo Marcial retoma o tema no epigrama XI, 2:

Triste supercilium durique severa Catonis

Frons et aratoris filia Fabricii

Et personati fastus et regula morum

Quidquid et in tenebris non sumus, ite foras.

Clamant ecce mei 'Io Saturnalia' versus:

Et licet et sub te praeside, Nerva, libet.

Lectores tetrici salebrosum ediscite Santram:

Nil mihi vobiscum est: iste liber meus est.

Vemos, assim, que Ausônio estabelece um diálogo intertextual com Marcial ${ }^{49}$, não só pela temática, mas pela alusão ao sintagma "regula morum". O que Gouveia faz, portanto, é inserir-se, pela alusão, nesse diálogo literário já estabelecido por uma alusão anterior.

A maneira como Gouveia faz isso, porém, é muito mais direta e explícita, não apenas em função do título do poema, mas porque reproduz quase na íntegra dois versos completos de Ausônio. Por outro lado, Gouveia, em 1539, é também muito mais franco e irreverente na posição que assume no debate, pois defende uma idéia contrária ao receituário clássico: enquanto os antigos dizem que o autor e a obra são coisas diferentes, e o epigrama é lascivo por natureza do gênero, independentemente do caráter do autor, Gouveia vai em sentido contrário, ao dizer que não basta ao poeta ser casto, é preciso que o poema também o seja. Trata-se, a bem da verdade, de pura irreverência e provocação, pois o próprio Gouveia, no

${ }^{49}$ No Cento Nuptialis, Ausônio refere-se expressamente ao verso de Marcial acima mencionado, e discute o mesmo tema. 
corpo de sua obra, obedece aos preceitos do gênero epigramático e também compõe poemas com variados graus de obscenidade.

Talvez por causa dessa incongruência, ou talvez porque sua irreverência tenha sido condenada pelos críticos, a versão de 1540 é bem mais comedida, e não avança no campo conceitual efetivamente envolvido no debate, passando ao largo da polêmica e limitando-se a fazer uma leve brincadeira, que, preservando e até enaltecendo Ausônio, incide apenas sobre a moral dos antigos romanos. De fato, todo o livro de 1540 é mais suave, bem menos jocoso e irreverente, mais compenetrado e bem acabado, adotando um tom mais equilibrado e clássico, como assim entendiam esse conceito os humanistas de Quinhentos. O poema a Ausônio exemplifica bem essa mudança: em 1539, Gouveia procura corrigir o que falou o grande monumento da poesia latina em território francês (e, indiretamente, corrigir toda a literatura clássica, de que Marcial foi apenas um exemplo); em 1540, Gouveia mantém a alusão, mas numa linha muito mais de continuidade que de revolução.

Qualquer que seja a versão, no entanto, cabe notar que a compreensão do epigrama de Gouveia requer a identificação da alusão e a leitura concomitante do texto aludido, e é isso que desejávamos demonstrar.

Vejamos outro exemplo desse procedimento poético e, continuando o exame das composições paródicas, abordemos agora um interesse conjunto de poemas que estabelece um diálogo com um conhecido epigrama de Marcial, chegando ao ponto de propor uma releitura e uma redefinição do pensamento contido no epigrama clássico. Note-se que esse grupo de poemas forma uma "cadeira de epigramas", coforme a definição teórica que expusemos no início deste capítulo. Portanto, aproveitaremos para analisar não somente as características paródicas da série, mas também os elementos que configuram o agrupamento dessa "seção epigramática".

O ponto de partida do ciclo gouveiano é o epigrama 16, Livro I, de Marcial:

Sunt bona, sunt quaedam mediocria, sunt mala plura,

Quae legis hic: aliter non fit, Auìte, liber.

A primeira imitação desse poema, em Gouveia, é o epigrama Ad Lectorem, o último do primeiro livro de epigramas, datado de 1539 :

Sunt mala, sunt quaedam peiora, et pessima plura. 
Arguit autorem pagina nostra suum.

Como se vê pela comparação, Gouveia manteve a gradação existente em Marcial, mas o último termo da gradação do original (mala) é agora o ponto de partida, e a gradação passa a ser feita pelo uso de graus diferentes do mesmo adjetivo, num poliptoto (mala, peiora, pessima). Assim, intensifica-se, em Gouveia, a figura de modéstia afetada, conhecida como "meiose" ou minutio. Se o primeiro verso é inteiramente calcado em Marcial, o segundo verso do dístico é bastante criativo, e propõe uma conclusão extraída do verso anterior: o de que, uma vez que só existem epigramas ruins, piores e péssimos, as páginas do livro revelam a (má) qualidade do autor. É evidente que, ao imitar Marcial, Gouveia propõe uma comparação deliberada com seu modelo e se coloca num papel diminuído, inferiorizado; afinal, se Marcial tem alguns poemas bons e muitos ruins, o humanista tem alguns ruins e muitos péssimos. Veja-se que essa conclusão é reforçada pelo uso do verbo arguit, que significa não somente “revelar, apontar", mas também “acusar, condenar". Mas se, por um lado, Gouveia se submete dessa forma a Marcial, por outro lado, um segundo efeito da leitura intertextual é bem diverso, pois o poeta lusitano revela a capacidade de subverter o modelo e extrair uma conclusão original a partir do "mote" do autor clássico; ou seja, a um só tempo Gouveia se rebaixa perante o modelo e se afirma como poeta capaz de emular o modelo.

Interessantemente, Gouveia retomará mais tarde sua própria imitação, refazendo-a, no livro de 1540, num epigrama (número 62) dedicado a Sébastien Gryphe (em latim, Sebastianus Gryphius), editor da obra de Gouveia.

Sunt mala, sunt peiora, Gryphi, sunt pessima plura.

Pauca tamen fuěrint hac ratione mala.

Nesta segunda imitação da cadeia de epigramas, o verbo "sunt", suprimido no final do primeiro verso da primeira imitação, por questão de métrica - uma vez que impedia a elisão -, reaparece, refazendo a anáfora interna e o assíndeto original. A posição do vocativo "Gryphi" se estabelece em função da métrica do hexâmetro, bem como pela eufonia e pela formação do sentido. Como conseqüência, formam-se três duplas de palavras ("sunt + adjetivo") na gradação. Também aqui se observa a mesma afetação de modéstia, construída a partir da escolha vocabular e da figura do poliptoto (mala, peiora, pessima). 
Todavia, neste segundo epigrama, é feito um arremate irônico e surpreendente sobre essa mesma figura, cuja fruição ganha nova dimensão a partir da percepção do diálogo proposto com os versos de Marcial.

Esse arremate é aberto pela antítese "plura / pauca", que se encontra enfatizada pela aliteração (em /p/) e pela posição consecutiva dos termos (encerrando um verso e iniciando o seguinte), em anadiplose. Trata-se de um desmentido que aponta em duas direções. Primeiro, dentro do próprio poema, ele desmente e desfaz a intenção do verso inicial, que era a de promover a humiliação do autor. Afinal, ele diz que o poeta teria escrito poucos poemas ruins. Um poeta que escreve poucos epigramas ruins não é tão mau assim. E talvez o próprio livro se salve, pois ele contém poucos poemas maus. Portanto, a primeira graça do texto provém do contraste e da contradição entre o primeiro e o segundo verso.

Porém, em segundo lugar, esse verso é um desmentido apontado contra o próprio Marcial. Afinal, em seu epigrama o poeta antigo havia concluído que não se fazem livros que não contenham uns poucos poemas bons e muitos ruins. Só existiria esse tipo de livro, sendo outro impossível. Mas Gouveia, de maneira provocante, nos diz que seu livro é o contrário do que disse Marcial, ou seja, o poeta português conseguiu a proeza de realizar a impossibilidade. Assim, uma segunda graça do epigrama renascentista, e talvez a mais importante (e talvez a intenção primeira do poeta, que tão deliberada e visivelmente indicou sua alusão), reside no contraste e na contradição entre seu epigrama e o epigrama sobre o qual foi modelado.

Contudo, ao perceber o potencial jocoso que tinha em mãos, Gouveia foi ainda mais longe, e prolongou a sua diversão (e a dos leitores eruditos que identificaram a alusão), ao compor mais dois epigramas que prosseguem no jogo e partilham do mesmo diálogo intertextual, ampliando a cadeia de poemas originada a partir de referências intratextuais. A fim de interpretar essa rede, apresentamos a seguir as duas composições. Em 1539, o epigrama II, $9:^{50}$

\section{AD LECTOREM}

Pauca damus, fateor, sed inepta epigrammata, Lector:

${ }^{50}$ Esse mesmo epigrama foi refeito em 1540, com o número 68 e o título "Petro Aluaro", apresentando pequenas diferenças que serão comentadas no próximo capítulo. 
Ergo multa nimis dicere iure potes.

O outro poema vinculado, de 1539 , é o epigrama II, $27:^{51}$

\section{AD IANVM HABERTVM}

Quae tu pauca putas Epigrammata, Iane, putarim,

Si bona, multa satis, si mala, multa nimis.

A intenção de formar um diálogo entre os poemas é clara, não só pela retomada de vocabulário (pauca, mala) e seus respectivos opostos (multa, bona), ou ainda de equivalentes semânticos (inepta), mas também pela repetição do título, no caso do epigrama Ad Lectorem.

No caso deste novo "Ad Lectorem", há também, na escolha da palavra "pauca" para abrir a composição, uma alusão a todo um conjunto de epigramas gouveianos em que ele brinca com a pequena dimensão do livro (constantemente chamado de libellum), seja do ponto de vista material (livro curto, pequeno, breve), seja do ponto de vista figurado (isto é, uma metonímia ou sinédoque em que o livro, como conjunto de poemas, incorpora as características do epigrama, reconhecido por sua brevidade), seja do ponto de vista da importância (pois a história da literatura freqüentemente atribuiu pouco valor à poesia epigramática, tida como menor, e os próprios autores novilatinos renascentistas, conscientes dessa questão, afetavam modéstia e marcavam posição ao incorporar a crítica que lhes era dirigida e nomear suas obras como sendo "nugae" ou "libelli") $)^{52}$.

Assim, abrir o poema com a oração "pauca damus" reverbera um conjunto de outras composições e assinala, mais uma vez, a idéia de que se trata de um "livrinho", curto, breve, com poucos versos de menor importância. Ao mesmo tempo, ao dar ao poema o mesmo título da primeira paródia de Marcial, e ao fazer a abertura com a palavra "pauca" (que remete a "plura", num contraste que seria explicitado no ano seguinte, no poema acima já analisado),

${ }^{51}$ Esse epigrama foi republicado em 1540, sem nenhuma mudança significativa, com o número 80 e o mesmo título, em dativo (Iano Haberto).

52 Na nomeação da obra como "libellus", não deve escapar de nossa percepção um outro valor, provocado pelo tom afetivo do emprego do diminutivo. 
ele sinaliza outro jogo emulativo, com o mesmo epigrama de Marcial (o célebre I, 16) e com a primeira paródia feita por ele mesmo (I, 64).

O leitor, tendo reconhecido as alusões (a partir do título e da primeira palavra) e tendo, conseqüentemente, esses dois conjuntos de epigramas em mente, ${ }^{53}$ como pano de fundo de sua leitura, vai mais uma vez se surpreender com a conclusão do segundo verso. Com efeito, enquanto ainda percorre o primeiro verso (sed inepta epigrammata, Lector), ele apenas confirma a situação de autocrítica e auto-humiliação do poeta, que admite (fateor) escrever pouco e mal. Mas a subversão e o gracejo virá com o segundo verso, em que o poeta inverte a proporcionalidade e a racionalidade para concluir que os poemas, embora poucos, são na verdade muitos, por serem ruins.

A conclusão paradoxal promove a graça e o riso não apenas pela contradição que constrói na transição do primeiro para o segundo verso, mas pela demolição do conjunto de poemas e conceitos a que faz alusão. Assim, o livrinho de poucos poemas, na verdade, é um longo livro de muitos versos. Ao mesmo tempo, os "muitos poemas ruins" (mala plura) de Marcial, que se haviam tornado "poucos ruins" (pauca mala) pela ginástica verbal de Gouveia, voltam a ser "muitos" (multa), num torneio sem fim que diverte, desloca e atormenta o leitor. No acúmulo de contradições e impossibilidades desfeitas e refeitas, o leitor pode rir dos oxímoros e também dos poetas que os propõem.

Não satisfeito, Gouveia investe no achado poético de que "poucos" poemas são "muitos", se ruins, e cria mais uma peça, explorando exatamente essa idéia, no epigrama II, 27. A alusão é provocada, no primeiro verso, pela palavra "pauca", que estabelece a ponte referencial, e se consolida com o vocabulário do segundo verso (bona, multa, mala, multa nimis) já visto nos demais poemas. A conclusão, decorrente desse desenvolvimento do epigrama II, 9, é a de que os "poucos" poemas sempre serão "muitos" (oxímoro), mas serão muitos o bastante, na medida certa (multa satis), se forem bons; e muitos, demais, em excesso (multa nimis) se forem ruins. Assim, pela ampliação da idéia contida no epigrama anterior, Gouveia consegue ir além no gracejo, sempre explorando as contradições, tanto em relação ao mundo real, quanto em relação aos poemas que lhe serviram de modelos a emular.

Antes de passarmos a uma conclusão geral sobre as paródias compostas por Gouveia, cabe observar dois aspectos notáveis dos dois últimos poemas comentados. Primeiro, a coesão

${ }^{53}$ A saber, o conjunto que parodia Marcial, I, 16 (sobre a qualidade dos epigramas) e o conjunto que trata da brevidade da poesia epigramática (em dimensão e importância). 
sonora dada pela aliteração de /p/ e /m/; sobretudo no epigrama II, 27, a aliteração de consoantes bilabiais é marcante. Segundo, a estrutura claramente simétrica e dicotômica, marcada por paralelismos e antíteses; mais uma vez, o epigrama II, 27 prima pela consistência e pelo uso consciente desse esqueleto, que se revela nos pares "putas / putarim", "bona / mala", "satis / nimis", pelo dissíndeto "si / si", pelo perfeito paralelismo dos dois hemistíquios do pentâmetro e, dentro de cada hemistíquio, pela oposição simétrica impecável dos dáctilos ("si bona / multa sa / tis" e "si mala / multa ni / mis").

Algumas conclusões podem ser levantadas em relação a esse tipo de composição poética que o presente trabalho denomina paródia; aliás, são conclusões muito semelhantes àquelas concernentes às traduções. Com efeito, podemos constatar nesses poemas o mesmo cuidado de Gouveia na composição dos versos, na aplicação de recursos literários clássicos, na busca de harmonia sonora e simetria sintática, na obediência às regras de versificação e métrica conformes ao cânone da Antigüidade, e na conformação temática, estrutural e vocabular aos preceitos do gênero epigramático.

Mas podemos observar, principalmente, sua intenção de dialogar com a tradição clássica, apropriando-se do repertório tradicional e manipulando-o para impor sua própria contribuição particular original no universo literário. Nesse processo, Gouveia vivifica os antigos, questiona-os e abre novas possibilidades de leitura de obras anteriormente consagradas. É claro que há, nessa dinâmica, o interesse de respaldar sua própria obra usando o anteparo de autores clássicos reconhecidos e valorizados em seu tempo, especialmente na França. Mas há também o desejo de interferir, à moda clássica, no vasto cabedal literário e de implantar seu nome, com personalidade original, nessa teia poética.

No caso dos poemas examinados acima, por exemplo, é óbvio que partem de versos de dois poetas clássicos, Marcial e Ausônio. Todavia, mais do que mero (ou ornamental) ponto de partida, de que a obra de Gouveia se distanciaria, eles funcionam como a contraparte e o interlocutor preferencial de um texto que se propõe alusivo.

Conseqüentemente, diante dessa evidente presença clássica nas composições paródicas gouveianas, a presente tese defende uma proposta de leitura e interpretação que leve em consideração o diálogo intertextual forjado por Gouveia, tal como procuramos fazer acima. Nesse sentido, os textos clássicos identificados são visto como a referência e o contraponto da leitura e de uma adequada interpretação dos textos de Gouveia, numa tentativa contínua de compreender os efeitos e as implicações resultantes do confronto dos textos. 
Tendo tratado de dois tipos diferentes de princípio de composição dos epigramas, a saber, a tradução e a paródia, passemos ao terceiro tipo de princípio de composição, a que denominamos "genérica livre", pois não se constrói sobre material versificado que foi vertido, adaptado, aludido ou modificado, mas sobre os elementos tradicionais da poesia clássica organizada em gêneros poéticos distintos, que obedeciam a regras de versificação e composição diferentes. Mais uma vez, portanto, vamos encontrar a presença clássica em Gouveia.

Para a análise desse terceiro tipo de composição, optamos por seguir a classificação que mencionamos em segundo lugar, mais acima, isto é, a classificação temática dos epigramas.

Sendo assim, dentre as quatro categorias que antes indicamos, vamos iniciar a análise com os poemas laudatórios, que apresentam um maior grau de homogeneidade se comparados com as demais composições.

De partida, selecionamos dois epigramas nitidamente panegíricos: os elogios a D. João III e aos poetas franceses. O primeiro é o epigrama II, 14, na edição de $1539:^{54}$

\section{AD IOANNEM LVSITANIAE REGEM}

Cum tibi nec uires, nec opes in proelia desint,

Fortuna arbitrio stetque cadatque tuo,

Quid non finitimos flamma ferroque lacessis?

Quid non iniustum ius tibi ubique facis?

Haec tua diuina est, ac plane regia uirtus,

Posse nocere quidem, nolle nocere tamen.

Nota-se o uso, mais uma vez, do dístico elegíaco, sendo que os dois primeiros dísticos formam um período sintático e têm uma unidade de sentido, funcionando como base do epigrama, ao passo que o dístico final tem a função de expor a conclusão, preparada no

${ }^{54}$ A versão de 1540 , epigrama número 58, contém duas divergências mínimas em relação ao texto anterior, motivo pelo qual abdicamos de comentá-las. 
quinto verso e arrematada no sexto. A estrutura, portanto, é dupla, isto é, contempla dois movimentos: a apresentação da questão (vv. 1 a 4) e a conclusão ou resposta (vv. 5 e 6 ).

Essa duplicidade estrutural se projeta em várias construções ao longo do epigrama, de tal forma que cada verso possui pelo menos um pareamento; assim, temos, no verso 1, "nec uires / nec opes"; no v. 2, "stetque / cadatque"; no v. 3, "flamma / ferroque"; no v. 4, "tibi / ubique"; no v. 5, "diuina / ac regia"; finalmente, no v. 6, inteiramente simétrico, há dois pareamentos: "posse nocere / nolle nocere", e "quidem / tamen”. Este último verso merece um comentário à parte, tal o equilíbrio da construção, que lembra, por sinal, o verso final do epigrama II, 27, comentado acima: Gouveia aproveita a perfeita divisão do pentâmetro em dois hemistíquios para construir um paralelismo notável, em que a palavra intermediária de cada hemistíquio (nocere) se repete, ao passo que a primeira e a terceira palavras apontam para seus respectivos correspondentes ("posse" remete a "nolle"; "quidem" remete a "tamen"); ambas as duplas são fortalecidas tanto pelo homeoptoto (no caso de "posse / nolle", dois verbos no infinitivo, com a sutilíssima mudança do valor modal ("poder / querer”); no caso de "quidem / tamen", dois advérbios ${ }^{55}$ ) quanto pela afinidade sonora (no caso de "posse / nolle", uma paronomásia, dada a semelhança sonora das consoantes e a equivalência das vogais, além da mesma extensão dos termos; no caso de "quidem / tamen", além de também terem o mesmo número de sílabas, formam homeoteleuto).

Outra construção muito elaborada é a do segundo dístico do poema, que prima pelo paralelismo: os versos 3 e 4 iniciam com uma anáfora dupla "Quid non”, e terminam com um homeoptoto (de dois verbos na segunda pessoa do singular do presente do indicativo, "lacessis / facis"), que forma uma paronomásia e um suave homeoteleuto. Os miolos dos versos também guardam correspondência, porque são formados por evidentes jogos sonoros (aliteração em /f/ no verso 3, paronomásias e assonâncias em /i/ e /u/ no verso 4) e porque repetem a disposição das palavras: concluindo cada miolo, temos um sintagma unido por conjunção copulativa “-que” (no v. 3, "flamma ferroque”, no v. 4, "tibi ubique”), enquanto na

55 A classificação gramatical varia de acordo com a obra de referência adotada: o OLD classifica quidem como partícula e tamen como advérbio; gramáticas normativas da língua portuguesa costumam classificar os equivalentes de quidem como advérbio ou partícula com valor adverbial, e tamen como conjunção. Sem entrar na questão, mantemos a idéia de homeoptoto, pois são dois termos invariáveis, que se prestam a modificar o valor da oração, e, na construção acima, estão sintaticamente vinculados, numa clara reciprocidade. 
parte inicial de cada miolo temos uma proximidade e uma remissão sonora dada pela assonância em /i/ e por outros ecos consonantais ("finitimos / iniustum ius).

Ainda em relação à dicotomia que permeia o epigrama, chama a atenção o oxímoro “iniustum ius", um par antitético ao gosto de Gouveia e da estética clássica, muito bem encaixado no poema. ${ }^{56}$

Em relação à sonoridade do epigrama, muitas são as particularidades, algumas já apontadas, como paronomásias ("iniustum ius", "tibi ubique"), aliterações (em /t/ no verso 2, e nitidamente em /f/ no v. 3, mas se estendendo de Fortuna, v. 2, a facis, v. 4), assonâncias (de /i/ e /u/, no v. 4, mas se projetando desde finitimos, v. 3, a diuina, v. 5) e homeoteleutos provenientes de homeoptotos (além dos já indicados nos finais dos versos 3 e 4 e no verso 6, temos "uires / opes", no v. 1).

Em relação ao conteúdo, o elogio do rei ocorre de maneiras diferentes a cada dístico. No primeiro, Gouveia faz uma referência positiva às principais qualidades que deseja destacar no monarca: o poder e a riqueza próprios de sua posição; nesse sentido, uires e opes são duas palavras essenciais ao louvor de Gouveia, pois indicam sua força e capacidade de ação, bem como a posse de todos os recursos necessários; no segundo dístico, Gouveia adota um instrumento caro à retórica demonstrativa: o elogio enfatizado pela negação dos vícios: a anáfora de "quid non" reforça bem a idéia de negar que o rei tenha um caráter injusto ou perverso. Bem preparada a introdução, por meio da qual o poeta mostrou que o rei, tendo força e poder, não os utiliza para o mal, chega a grande inferência, que tem como guia a palavra uirtus, muito freqüente na poesia laudatória de Gouveia; mas, neste epigrama, uirtus vem realçada por uma dupla de adjetivos: diuina e plane regia. Esses adjetivos têm função importante, pois, por um lado, indicam a fonte e a natureza do poder real, bem como a

${ }^{56}$ É preciso que se reconheça que esse par antitético e todo o verso em que ele se encontra foi uma adaptação, para o poema, do verso 54, do Epicedion Drusi, de Ovídio: "Saevit et iniustum ius sibi ubique facit". Mas não se pode negar o mérito de Gouveia, que, no último verso de seu epigrama, encontrou uma enunciação muito mais bela e poética para uma idéia apenas sugerida no verso 47 da mesma obra de Ovídio: "Nec nocuisse ulli et fortunam habuisse nocendi”. Seja como for, as alusões apenas favorecem o propósito do humanista português, que, dessa maneira, associa a figura de D. João III à família dos Césares romanos. 
plenitude de sua capacidade de governar, e, por outro lado, elevam e divinizam a figura de D. João III, colocando-o como um deus no governo da nação lusitana. A prática de divinização do destinatário é comum nos panegíricos gouveianos, mas aqui ela ocorre de modo muito apropriado e direto, pela aposição do adjetivo "diuina" ao termo "uirtus". Feito o supremo elogio, o epigrama traz o desfecho já comentado, em que Gouveia, com agudeza espiritual e simetria de composição, apresenta uma conclusão que enfeixa o desenvolvimento anterior do poema e, ao mesmo tempo, lembra a cunhagem de um lema heráldico.

O poema visto logo acima guarda muitas características comuns à poesia laudatória de Gouveia. Já o epigrama a seguir tem diversos aspectos peculiares, mas que são interessantes de observar pela referência a elementos típicos da poesia clássica. Trata-se do epigrama II, 40 (de 1539) ${ }^{57}$, ou seja, o penúltimo do livro, quase um envoi, em que Gouveia, embora se dirigindo a Jacques de Beaune, faz um balanço elogioso da literatura francesa da época, louvando um conjunto de poetas novilatinos.

\section{AD IACOBVM BELNAEVM}

Ecce repente uno felix dat Gallia partu,

Doletum Iambico trucem:

Macrinum curua gnarum testudine, Diuum

Restinguere ardenteis minas:

Borbonium Latiis salibusque, iocisque fluentem,

Nugisque gratum seriis:

Vosque o Vultei, Brixi, Marthane, Ducheri,

Sacrae decora Poeseos.

Quaeris quid facio? numero, Belnaee, poetas,

Quos Gallia protulit ferax.

Ao menos dois elementos desse poema devem ser comentados: a adjetivação laudatória e a referência a ícones dos diferentes gêneros da poesia clássica.

57 A versão de 1540, epigrama 89, apresenta pequenas divergências de ortografia, pontuação e vocabulário, que serão comentadas no próximo capítulo da tese. 
Quanto aos adjetivos, eles foram escolhidos para ressaltar cada uma das atividades a ser valorizada para cada uma das personalidades do epigrama. Assim, a França (Gallia) é "felix" e "ferax", dois adjetivos cognatos, relacionados à fecundidade, que realçam seu caráter de nação produtora de grandes vultos, conforme indicam os verbos dat e protulit. Veja-se ainda o sintagma "uno partu" a reforçar esse aspecto procriativo.

Na seqüência, temos adjetivos aplicados a três poetas: trucem, a Dolet; gnarum, a Macrin; fluentem e gratum, a Bourbon. Cada um dos adjetivos está vinculado ao gênero poético praticado pelo poeta em questão. Nesse sentido, Dolet, um erudito renascentista, adepto de diferentes estilos de composição, destacou-se na confecção de iambos, e daí a escolha de "trux", no sentido de "feroz" ou "ferino", para enaltecer sua veia poética satírica. Já Macrin é louvado pela poesia lírica, de teor erótico, aplicando-se a ele o epíteto "gnarus", isto é, "conhecedor", "hábil”, qualidade importante num gênero poético que requer, aos olhos dos renascentistas, maior apuro literário. Finalmente, Bourbon, compositor de poesia epigramática, é investido das virtudes de "fluens" e "gratus", ou seja, "fluente" e "agradável, bem visto", pontos essenciais da boa poesia ligeira.

No quarto dístico, Gouveia abrange um conjunto de poetas notáveis da época, e resume suas qualidades no verso 8, "Sacrae decora Poeseos". Vemos aqui um raro emprego do genitivo de "poesis" com declinação em “-eos”, imitada do grego; o seu adjetivo é "sacrae", isto é, "sagrada", valorização importante do papel e da posição sublime da poesia, que, por metonímia e pela posição da palavra (em primeiro lugar no verso, em seguida à enumeração dos autores), se transfere aos poetas, por projeção. De certa forma, isso corresponde à divinização dos elogiados, comum ao gênero panegírico. Finalmente, "decus", com o significado de "glória, esplendor", aqui empregado no plural para representar os poetas mencionados, embora seja um substantivo, tem função basicamente atributiva, e todo o sintagma "sacrae decora poeseos" qualifica e louva em alto grau os neolatinistas listados.

Como vimos, os adjetivos foram escolhidos por seu vínculo com o gênero poético praticado por cada um dos poetas elogiados. Mas há outros elementos, no poema, que apontam para a teoria da composição genérica. No caso de Dolet, citado no verso 2, além do adjetivo "trucem", já comentado, temos a menção direta ao gênero por meio do termo Iambico, referência ao metro utilizado canonicamente pelos autores clássicos na composição de obras de viés satírico, ou seja, o jâmbico, pelo qual o próprio gênero passou a ser conhecido e identificado. 
No segundo dístico, Macrin é associado à poesia lírica amorosa (e, por aproximação genérica, com a poesia elegíaca) por dois claros ícones clássicos: no verso 3, pelo sintagma "curua testudine", e, no verso 4, por "ardenteis minas". "Testudo", em latim, significa "tartaruga", mas, por metonímia, também designa o "casco de uma tartaruga". Do uso do casco como caixa de reverberação da lira, por um novo tropo metonímico, "testudo" passou a indicar a lira, e, conseqüentemente, foi termo icônico da poesia lírica. Quanto a "ardenteis minas", no verso 4, a expressão é uma clara referência às ameaças amorosas, num vocabulário associado à poesia clássica amorosa e elegíaca.

No terceiro dístico, Gouveia falará de Bourbon. À parte os adjetivos já analisados, "fluentem" e "gratum", há um conjunto de termos de matriz clássica relacionados à poesia epigramática: no verso 5, a frase "Latiis salibusque iocisque" é menção direta aos elementos que constituem a essência dessa poesia, notadamente os "sais", isto é, "os temperos, os ditos picantes, mordazes, inteligentes, saborosos", e os "jogos", isto é, "os chistes e gracejos". A presença deles é que garante que se atinja a suprema virtude do epigrama, ou seja, a agudeza, exposta, por exemplo, nas conclusões inusitadas, plenas de humor e sagacidade. Ao mesmo tempo, o adjetivo "Latiis" revela uma clara opção por uma poesia epigramática de tom, humor e teor latinos, cuja fonte e repertório se encontram nos autores da Antiga Roma, sobretudo Marcial, e não entre os gregos.

Outro ícone da poesia ligeira é o termo "nugis", que ajudou a formar a identidade desse gênero poético e que acabou por ser assumido por seus poetas, desde a Antigüidade. Seu significado é "ninharia, bagatela, bobagem, coisa de pouco valor", cuja atribuição pejorativa ao falar desse gênero poético foi invertida por seus autores, que buscaram investir a "leveza poética" de um caráter positivo, e enxergavam nisso uma qualidade louvável. Gouveia, com muita habilidade, forma um curioso oxímoro, ao atribuir a "nugis" o adjetivo "seriis". O humanista português já havia desenvolvido essa idéia em dois epigramas anteriores, do mesmo livro de 1539, os de número I, 60 e II, 18. Nessas duas composições, Gouveia havia atacado o julgamento daqueles que desvalorizavam a poesia ligeira e a consideravam incompatível com a legítima qualidade literária. No poema II, 18, por sinal, o poeta luso já havia usado as palavras "nugae" e "serium" no mesmo verso. O diferencial da composição ora analisada é que ele associa brilhantemente e com agudeza um termo ao outro, subvertendo a expectativa dos que costumam identificar as nugae como poesia leviana e sem valor. O conjunto do dístico, portanto, presta uma grande homenagem a Bourbon, sendo o oxímoro "nugis seriis" um contundente arremate. 
Até aqui, confirmamos, mais uma vez, a forte presença da poesia clássica na composição poética de Antônio de Gouveia, de que o poema II, 40, recém analisado, presta um eloqüente testemunho.

Ainda tratando da poesia panegírica, aproveitamos para tentar esclarecer com mais nitidez a categoria proposta nesta tese, que permite agrupar poemas de Antônio de Gouveia em "ciclos de epigramas". Para isso, vamos agora abranger um outro conjunto de textos de Gouveia, segundo uma estratégia de composição que os aproxima: a figura retórica da "preterição", aqui entendida como o fingimento de uma negação declarada de proceder ao discurso, ao mesmo tempo em que ele é feito. No caso de Gouveia, trata-se de uma declaração de incapacidade de compor um panegírico, por insuficiência de recursos para tratar de temas muito elevados. Sendo assim, a preterição está motivada por uma posição de humildade do poeta, ou seja, por um recurso de modéstia afetada ou minutio. Curiosamente, todos esses cinco poemas pertencem ao volume de 1540, que possui justamente cinco poemas laudatórios a mais do que no ano anterior. Vemos, portanto, que, ao lado do acréscimo de versos dessa natureza, há uma estratégia de composição muito evocada pelo poeta, nos epigramas de louvor desse ano, o que confere grande coesão à obra de 1540. Os números dos poemas foram mantidos, a seguir, na reprodução dos textos latinos.

\section{[4]}

\section{RODORICO FERNANDO, IOANNIS LVSITANIAE REGIS LEGATO SANCTISSIMO}

O Decus, o patriae, o gentis noua gloria nostrae,

Vatibus argumentum ingens uariumque futuris,

Tentarem, Fernande, lubens te imponere olympo,

Et laudum cumulos dicendo aequare tuarum,

Haec tua ni uirtus hominum laude altior omni

Erigeret sese, et caput inter poneret astra. 
O Regum soror et coniunx, o altera partus

Sors magni ingentisque, o ingens fratris imago,

Te canerem, nomenque tuum, nomenque tuorum,

Virtutemque aequatam astris, si pondera laudum

Tantarum exiguae possent attollere chartae.

[41]

BLANCHAE DVRAEAE IACOBI

REGINALDI ALENII VXORI INTEGERRIMAE

Quae tua nobilitas, uirtus, prudentia, morum

Suauitas, quae gratia,

Quae porro tibi mellitae facundia linguae,

$\mathrm{Tu}$ dicere queas optime.

[49]

\section{SANCTO AMANTI EQVITI HIEROSOLYMITANO MERITISSIMO}

O Sancte, o terrae ac pelagi defuncte periclis,

$\mathrm{O}$ inuicte animo, o magnum patriae ornamentum,

Ten'ego commendare queam? Iouis aurea proles

Musae alium date Moeoniden, en alter Vlysses.

[76]

\section{IACOBO TEVIO}

Si mihi quam stupida est, tam lingua diserta fuisset,

Dixissem quam sit lingua diserta tibi. 
Interessa-nos falar, inicialmente, das características comuns aos cinco epigramas. A principal delas, que deu ensejo ao agrupamento dos poemas, é a figura da preterição. Nos cinco poemas, ela aparece, mas explicitada de formas diferentes. Nos epigramas 4, 22 e 76, a preterição é indicada por um verbo numa forma de representação do "irreal" do presente (no epigr. 4, v. 3, tentarem; no epigr. 22, v. 3, canerem; ambos no imperfeito do subjuntivo) ou do passado (no epigr. 76, v. 2. dixissem, mais-que-perfeito do subjuntivo); esses três verbos se ligam a construções condicionais, assinaladas pelas conjunções ni (epigr. 4, v. 5) ou si (epigr. 22, v. 4; epigr. 76 , v. 1). No epigrama 41, a preterição é sugerida, no verso final, pela somatória do verbo modal queas, o pronome pessoal tu e o advérbio optime, dando a entender que a própria homenageada é que reúne as melhores condições para falar de si mesma. Finalmente, no epigrama 49, Gouveia usa o mesmo verbo modal queam, agora na primeira pessoa do singular, numa interrogação retórica, cuja resposta completa a preterição pelo uso de um imperativo date que descarta a pessoa do poeta.

Os motivos da preterição são basicamente dois: nos epigramas 4 e 49, a figura louvada encontra-se num patamar excepcional e sobre-humano, inatingível pelo poeta; nos epigramas 41 e 76, falta ao poeta a eloquiência necessária para a tarefa. O epigrama 22 compartilha de ambos os motivos, pois, de um lado, a rainha D. Margarida está em posição social muito superior à das demais pessoas e possui virtudes celestiais; de outro lado, como afirma o poeta, suas páginas são limitadas demais para dar conta de pessoa tão superior. As construções condicionais, dos epigramas 4, 22 e 76, dão conta justamente dessas limitações: no epigrama 4, Gouveia diz que tentaria enaltecer Rui Fernando, se suas virtudes não se elevassem acima de todos os homens; já no epigrama 22, o poeta louvaria a rainha, se sua obra exígua pudesse suportar o peso de tamanhas qualidades; finalmente, no epigrama 76, Gouveia teria elogiado Diogo de Teive, se tivesse tido uma capacidade discursiva tão fluente quanto a do homenageado.

Sendo estes epigramas panegíricos, é natural que procurem elevar a personalidade a que são dedicados. Acabamos de ver, aliás, como essa elevação se liga à figura da preterição. A forma de elevação varia de grau nos diferentes epigramas. Há desde uma estratégia de divinização, no caso dos epigramas 4 e 22, em que os destinatários são colocados entre os astros, até um simples elogio da eloqüência, no caso do epigrama 76. Entre esses extremos, temos uma espécie de mitificação (no epigr. 49, Saint-Amant comparado a Ulisses) e um enaltecimento acumulado (no epigr. 41, inúmeras qualidades atribuídas a Blanche Durer). 
Na disposição dos elogios e dos demais elementos do poema também há semelhanças entre as composições. Com exceção do epigrama 76, todos começam com um acúmulo de elogios. No caso dos epigramas 4, 22 e 49, o início é construído com uma seqüência de vocativos, assinalados pela interjeição "o", repetida sempre três vezes. ${ }^{58}$ Igualmente nos três a preterição vai se dar no terceiro verso, independentemente da extensão das composições.

O acúmulo dos elogios ocorre pela sobreposição de adjetivos e substantivos. Nesse ponto, o epigrama 41 se diferencia, pois Gouveia dá preferência ao uso de substantivos, cinco em seguida, nomeando diferentes qualidades da homenageada, para apenas no verso 3 usar o adjetivo mellitae, ao lado do substantivo facundia. Sua estratégia mais constante, no entanto, é usar um misto de adjetivos e substantivos, como vemos no epigrama 4 (e.g., noua gloria; argumentum ingens uariumque), no 22 (e.g., altera partus sors magni ingentisque; ingens fatris imago), no 49 (e.g., inuicte animo; magnum ornamentum) ou no 76 (e.g., lingua diserta).

Outra estratégia de Gouveia é pontuar o poema com o pronome pessoal "tu" (ou seu correspondente possessivo), referindo-se ao homenageado. Se nos epigramas 49 e 76 ele aparece apenas uma vez (epigr. 49, v. 3, te(n'); epigr. 76, v. 2, tibi), mas em posições enfáticas (no epigr. 49, abrindo verso e reforçado pela partícula interrogativa "-ne"; no epigr. 76, em fim de verso e última palavra do epigrama), nos epigramas 4, 22 e 41 ele aparece três vezes, sempre em poliptoto. No epigrama 4, temos te (v. 3), tuarum (v. 4) e tua (v. 5); no epigrama 22, temos o poliptoto explícito no verso 3 (te, tuum, tuorum); no epigrama 41, temos tua (v. 1), tibi (v. 3) e tu (v. 4).

Talvez em parte como reflexo disso, podemos notar uma aliteração da consoante /t/ nos cinco epigramas em exame, embora com menor intensidade no epigrama 76, em que se evidenciam mais os paralelismos, as antíteses e a aliteração do /d/. Nos outros quatro epigramas, a aliteração é constante, somada à recorrência de outras consoantes, que variam em cada composição. Assim, no epigrama 4 há aliteração em /t/ e em /m/; no epigrama 22, há aliteração em /t/ e /g/; no epigrama 49, há aliteração em/t/, /m/ e/p/.

O epigrama 41 destaca-se novamente, não apenas porque a aliteração em "t $t$ ” é a única prevalente, mas também porque há uma notável variação nas sílabas formadas com essa

\footnotetext{
${ }^{58}$ No caso do epigrama 4, um dos modelos da abertura pode ser o verso V, 2, 49, dos Tristia, de Ovídio, "o decus, o patriae per te florentis imago", entre outras formulações semelhantes que se encontram em autores clássicos.
} 
consoante, ou seja, uma grande variatio vocálica; tomando apenas as sílabas formadas com /t/, temos a seqüência "tu-tas-tus-ti-tas-ti-ti-tae-tu-ti". É bem verdade que a mesma variação pode ser observada, até com muito mais colorido, nos epigramas 4 e 22. Senão, vejamos: temos no epigr. 4: "tri-tis-trae-ti-tum-tu-ten-ta-te-et-tu-tu-tus-ti-et-et-ut-te-et-tra"; e, no epigr. 22: "et-te-tus-tis-tris-te-tu-tu-tu-tem-tam-tris-tan-ta-ent-to-tae".

Podemos observar, dessa forma, como Antônio de Gouveia trabalha de modo consciente e elaborado, apresentando uma confecção de versos muito coerente, com estilo pessoal e numa linha constante. Uma vez que nos interessa, sobretudo, os princípios de composição utilizados pelo humanista português, podemos observar, no conjunto de poemas examinados até aqui, não apenas a forte presença das fontes clássicas e dos preceitos da composição genérica, mas o uso criativo e aprimorado do ferramental e dos recursos poéticos tradicionais, concernentes à disposição, escolha vocabular, sonoridade ou exposição de figuras, argumentos e idéias, na construção original de cada poema.

$$
* * * * *
$$

Passemos agora aos epigramas denominados sepulcrais. Como vimos anteriormente, eles podem ser subdivididos em epigramas que se apresentam como epitáfios, isto é, se configuram como placas tumulares, e epigramas meramente fúnebres, por terem a morte como tema, mas não a configuração de uma lápide. De início, selecionamos para análise um epigrama de cada subtipo.

Dentre os epitáfios, já comentamos mais acima o epigrama em memória de Lucila. Ao lado dele, optamos por tomar, como composição típica, o epigrama em memória de Thomas More, publicado, com o número 43, em 1540.

\title{
D. M. THOMAE MORI
}

\author{
VITAM TIBI TVA THOMA MORE IN- \\ TEGRITAS ADEMIT, GLORIAM VERO \\ PEPERIT SEMPITERNAM. CINERI \\ PRODEST, QVAE VIVO NON PROFVIT \\ INNOCENTIA.
}


Primeiro, cabe comentar que a própria opção pela composição de um epitáfio indica o respeito de Gouveia pela tradição clássica, uma vez que essa seria a origem mesma do epigrama e uma das aplicações mais comuns desse gênero na Antigüidade, sobretudo nos primórdios da configuração da poesia epigramática. Essa reverência é ressaltada se lembrarmos que Gouveia publicou 9 epigramas sepulcrais na edição de 1539, e aumentou esse número para 16 epigramas, no volume de 1540. Nesta última edição, aliás, ele tomou o cuidado de montar o texto dos epitáfios em caixa alta, fortalecendo a imitação das placas tumulares, como já foi mencionado anteriormente. Esse recurso tipográfico aparece no epigrama acima reproduzido.

Se a opção de compor um epitáfio indica seu conhecimento da tradição clássica, a escolha de Thomas More como homenageado fortalece seu vínculo com o movimento humanista europeu. O erudito inglês havia sido executado poucos anos antes, em 1535, por ordem de Henrique III, por manter a integridade de seus princípios morais e religiosos e não se submeter à nova igreja anglicana, fundada pelo rei britânico para legitimar seu divórcio com Ana de Aragão e acomodar seu casamento com Ana Bolena. Apesar de a relutância de More ser pacífica, serena e tácita, o monarca não lhe perdoou; contudo, o martírio de Thomas More teve larga repercussão na Europa, especialmente entre os intelectuais da república das letras. O epitáfio concebido por Gouveia mostra sua afinidade com os princípios do humanismo e marca sua posição franca e atualizada sobre esse fato importante.

Bem de acordo com os episódios da história da vida do retratado, o epitáfio atribui a More, fundamentalmente, duas virtudes: integritas e innocentia. Esse é o par fulcral que estrutura a composição, sendo que "integritas" comanda, como sujeito que é, o primeiro período sintático do texto, que corresponde à primeira parte do epigrama, enquanto "innocentia", sujeito do segundo período (e da segunda metade do texto), irradia a formação sintática da segunda parte. Essa duplicidade simétrica, tão apreciada por Gouveia, está presente em todo o epigrama, como podemos perceber pela constatação do número de pareamentos existentes na composição. Assim, "integritas" rege dois verbos paralelos, "ademit" e "peperit" (um homeoptoto), enquanto "innocentia" rege outro par, "prodest" e "profuit" (um diptoto do verbo prosum, prodesse, formando, no nível sonoro, um eco anafórico por figura etimológica).

Há também pares de substantivos correspondentes, como "uitam / gloriam" (duplo complemento dos verbos do primeiro período composto) e "cineri / uiuo" (duplo complemento dos verbos do segundo período). Ambos, aliás, formam antíteses, uma das 
figuras de pensamento privilegiada em Gouveia. Se notarmos que as palavras que restam também são pares ("tibi / tua"; "Thoma / More"), verificaremos a esfuziante simetria dicotômica da peça.

Quanto ao diptoto "tibi tua", enfatizado pela aliteração (que já vinha antecipada em "uiTam” e, por sua vez, antecipa "Thoma”) e pela posição consecutiva, já vimos como o uso dos pronomes da segunda pessoa é caro a Gouveia nas peças de homenagem; esse poliptoto, por seu lado, anuncia o vocativo "Thoma More", outro recurso freqüente na poesia gouveiana, também realçado pela aliteração, agora em $/ \mathrm{m} /$.

A duplicidade constitutiva do epigrama parece mesmo contaminar as aliterações e paronomásias, que se fazem aos pares, em palavras próximas, como em "in $\underline{\text { TeGriTas } /}$

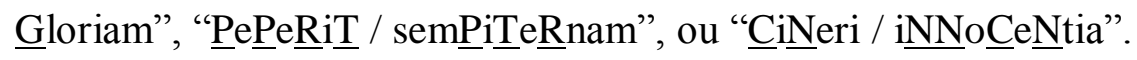

Já que falamos de um epitáfio, cabe enfocar o vocabulário próprio do gênero. Nesse sentido, duas palavras são típicas da composição sepulcral: gloriam e cineri. A efetivação da glória eterna ("gloriam sempiternam”), tanto no sentido terreno quanto espiritual-religioso, deve ser o voto primordial da placa fúnebre, que procura, da sua parte, colaborar para que se preserve o culto à memória da personalidade falecida. Já o termo "cineri", referindo-se às cinzas, isto é, aos restos mortais, entra no poema como menção e signo usual da morte.

Para encerrar a análise desse epigrama, façamos uma última reflexão sobre a palavra innocentia, já anteriormente abordada. É de notar que ela ocupa a última posição do epigrama, aspecto que projeta sobre ela um vigor e uma importância sobrelevados. Ademais, graças à tradicional criação de expectativa no desenrolar de um epigrama, que faz com que se infunda de grande peso e carga significativa o arremate de uma composição, a palavra "innocentia" acaba por pontuar todo o epitáfio e por transferir para o homenageado todo o conteúdo semântico positivo de que se reveste, qualificando, dessa maneira e definitivamente, a figura de More.

Em relação aos epigramas fúnebres, utilizaremos como exemplo a peça escrita por Gouveia em homenagem ao advogado francês Jean Montagne. Vejamos, primeiro, a composição de 1539 (Epigr. I, 6): 


\section{M. MONTANI IVRISPERITI}

Montanus trepidos media de morte trahebat, Viribus eloquii consiliique reos.

Mors regnum, lucrumque Charon, duraeque Sorores

Clamabant uires succubuisse suas.

Nec mora, Montanum rapiunt sine legibus ullis.

Ah, non sic fatis abstulit ille reos.

O mesmo epigrama, refeito em 1540 (Epigr. 67):

\section{M. IOANNIS MONTANI IVRISPERITI}

Montanus trepidos media de morte trahebat

Viribus eloquii consiliique reos.

Lugebant erepta sibi sua numina Parcae,

Nec uolui fusis ferrea fata suis.

Haud mora, Montanum rapiunt sine legibus ullis.

Ah non sic fatis abstulit ille reos.

O epigrama é composto de três dísticos elegíacos. A segunda versão alterou, principalmente, o dístico intermediário, mantendo quase sem retoques os outros dois dísticos. Isso nos permite tecer comentários válidos para ambas as versões. ${ }^{59}$

Primeiro, podemos observar o desenvolvimento retórico do epigrama, em que os três dísticos perfazem nitidamente as funções de exórdio, desenvolvimento e conclusão. A influência da retórica está em plena consonância não só com a figura do homenageado, um advogado, mas com a própria concepção poética que rege a composição de peças do gênero epidítico ou demonstrativo, visando, neste caso, ao elogio de uma personalidade. Não é demais lembrar que retórica e poética compartilham muitos elementos na Antigüidade, e que a poética clássica está completamente imbuída de preceitos retóricos.

${ }^{59}$ As diferenças entre as duas versões serão analisadas no próximo capítulo. 
Gouveia recorre aos lugares comuns desse tipo de poema. Assim, além de destacar, já no título, a profissão do falecido amigo, faz referência, no dístico de abertura, à carreira e às ações de Montagne; ao mesmo tempo, ressalta suas qualidades de eloqüência e discernimento (uiribus eloquii consiliique).

No desenvolvimento, em ambos os epigramas Gouveia faz uma alusão ao plano divino, estratégia que resulta na elevação da própria figura de Montagne. A hipérbole é reforçada pelo fato de estar construída em antítese, isto é, ao invocar seres infernais, Gouveia sublinha, por contraste, o valor positivo de Montagne e seu principal atributo de inimigo da morte.

A conclusão enfeixa os dísticos anteriores, apontando para a grandeza do advogado, superior às Parcas por seu sentimento de justiça, mesmo que submetido a elas, que o arrebatam sem direito nenhum (rapiunt sine legibus ullis). O último verso, em especial, apresenta o desfecho surpreendente e agudo, ao gosto epigramático, desfecho que foi sendo preparado ao longo de toda a composição.

Mais uma vez, a duplicidade estrutural, tão ao gosto de Gouveia, se faz notar. Aqui, é a constante dicotomia ou antítese entre dois pólos, ocupados por Montagne e pela morte, que perpassa e estrutura todo o poema. Veja-se como o poeta constrói a oposição evitando que eles ocupem as mesmas porções do epigrama. Assim, no primeiro verso, "Montanus", antes da cesura trimímere, se afasta da palavra "morte", que pertence ao cólon final, depois da cesura pentemímere. O primeiro dístico é dominado pela presença de Montagne, em contraste e em evidente separação com o segundo dístico, que se refere à morte. No terceiro dístico, mais uma vez, as cesuras separam os dois, digamos, "rivais": no quinto verso, a cesura pentemímere separa "Montanum" do verbo rapiunt, o qual, isolado entre duas cesuras, é realçado na sua conotação negativa. Já no pentâmetro final, em quiasmo com o hexâmetro, "fatis" aparece no primeiro hemistíquio, ao passo que "ille" (pronome que retoma "Montanus") está no "campo oposto", no segundo hemistíquio, propositalmente colocado ao lado dos "reos" que passara a vida defendendo.

A antítese, estruturante do epigrama, ainda pode ser vislumbrada no primeiro verso, na oposição, marcada pela cesura trimímere, entre Montanus e trepidos. Ou seja, Montanus está sempre ao lado dos réus (não apenas no último verso, como também no segundo, em que reos se faz acompanhar pela pujança do orador, uiribus eloquii consiliique), inclusive no primeiro verso, mas em oposição (dada pela cesura) ao temor daqueles que defende. A circularidade da conclusão, de modo metódico, se dá através da retomada das duas primeiras palavras do 
epigrama pelas duas últimas, isto é, "Montanus-trepidos" e "ille-reos", garantindo a composição em anel da peça.

Se notarmos, finalmente, a acentuação dos pés do dístico inicial, veremos que no primeiro verso só há uma homodinia (concordância do acento da palavra com o icto do pé métrico), no quinto pé, iniciado pela palavra morte, que dessa forma é destacada; ao contrário, quando Gouveia elogia a eloqüência de Montagne, o verso flui em homodinias, a começar por uiribus, no pentâmetro construído com quatro pés dáctilos.

Há pouco falamos das cesuras. Nunca é demais relembrar que uma das funções clássicas da cesura é enfatizar as palavras que vem antes da pausa, e, com efeito, Gouveia esteve atento a isso, pois a palavra Montanus, nas duas aparições no epigrama, esteve realçada por esse recurso, antecedendo pausas estratégicas, já acima comentadas.

Em relação ao vocabulário de cunho genérico, ele abunda nas duas versões do poema: temos, no texto publicado em 1539, a idéia de morte referida direta ou indiretamente muitas vezes: morte (v. 1), mors (v. 3), Charon (v. 3), durae Sorores (v. 3) e fatis (v. 6); outras palavras podem ser associadas à iminência da morte, como trepidos (v. 1), reos (vv. 2 e 6), succubuisse (v. 4) e rapiunt (v. 5). No texto de 1540, encontramos ainda, no segundo dístico, Parcae e o sintagma fusis ferrea fata suis, além de lugebant, que abre o mesmo dístico.

Antes de passarmos a outro tipo de composição, será oportuno abordar um conjunto de três composições que formam um outro "ciclo de epigramas". O elemento que permite agrupá-los é o recurso da alegoria, que faz representar, nos três textos, o enterro simbólico de qualidades abstratas, personificadas em prosopopéia, que acompanham (ou não) o falecido. Dos três epigramas alegóricos, dois estão interligados mais intrinsecamente, numa referenciação mútua, pois usam do mesmo lugar-comum do "túmulo exíguo" para estruturar o texto. Citam-se a seguir os epigramas, começando pelo epigrama I, 5, publicado em 1539:

\section{M. IOANNIS BAROLLAE}

In quo certarunt Fortuna, Scientia, Virtus,

Barolla exiguo conditur hoc tumulo.

At uiuos inter Fortuna, Scientia, Virtus,

Casurum nullo tempore nomen habent.

Si quaeris quid non una sint ista sepulta, 
Exiguo a tumulo non potuere capi.

Como a versão de 1540 (Epigr. 11) apresenta-se com significativas mudanças nos versos 2 e 3, apresentamo-la a seguir: ${ }^{60}$

\section{M. IOANNIS BAROLLAE SENATORIS BVRDIGALENSIS}

In quo certarunt Fortuna, Scientia, Virtus,

Barollae exiguus contegit ossa lapis.

Illa tamen, memori si quid modo fidimus aeuo,

Casurum nullo tempore nomen habent.

Si quaeris tumulo quid non condantur eodem:

Exiguo a tumulo non potuere capi.

O segundo poema do ciclo é o de número II, 30, na edição de $1539:{ }^{61}$

\section{M. IOANNIS ALBERTI}

Ne tumulum Alberti exiguum mirere, Viator:

Nam quo potuit cumque obtegi

Albertus tumulo, doctae potuere Sorores,

Et Gratiae, et Pietas tegi.

O terceiro poema da série pertence ao volume de 1540, epigr. 17:

\section{M. ALDI MANVTII ROMANI}

Si nescis cur quae cinerem tegit urna, Manuti,

Haec eadem Musas non tegat urna nouem:

Ignoras studio quanto perfecerit ille,

${ }^{60} \mathrm{O}$ comentário concernente às alterações será realizado no próximo capítulo.

${ }^{61}$ A versão do ano seguinte é exatamente igual, motivo pelo qual não será reproduzida neste capítulo. 
Incolumes possent ut superesse patri.

Como dito antes, o que unifica esses poemas é a referência ao enterro simbólico de qualidades abstratas personificadas, ora por prosopopéia, como no epigrama I, 5, ora por metonímia mitológica (as doutas Irmãs, as Graças e a Piedade, no epigr. II, 30, ou as Musas, no epigr. 17). Essa opção conduz ao uso de um vocabulário perfeitamente enquadrado na tradição do gênero sepulcral; são substantivos como "tumulus" (epigr. I, 5; 11; e II, 30), "lapis" (epigr. 11) ou "urna" (epigr. 17), e verbos como "condo" e "sepelio" (epigr. I, 5), ou "tego" e seu derivado "obtego" (epigr. II, 30 e 17). Além dessas referências diretas ao enterro, temos uma série de termos relacionados à morte: no epigr. I, 5, podemos apontar: "uiuos" (por contraste), "casurum" (particípio futuro do verbo cado, cujo sentido conotativo é “morrer"), e "tempore" (o tempo que consome a vida funciona como memento mori); no epigr. 11, temos "ossa" (os restos mortais, ícone da morte) e "memori aeuo" (mais uma vez o tempo, aqui projetado no futuro como possível guardião da memória do passado); no epigr. 17, encontramos "cinerem" (as cinzas, já utilizado por Gouveia, como ícone da morte, no epitáfio de Thomas More) e "superesse" (o verbo "sobreviver", por oposição à morte). O verbo superesse, aliás, já havia sido empregado no epitáfio a Lucila, onde, por sinal, também aparece a palavra "tumulus", na mesma construção "hoc tumulo" que ressurge no epigrama I, 5, a Jean D’Yberrola. Essa frase, no sentido de "neste túmulo jaz...” ou "neste túmulo está enterrado...", é canônica na epigrafia tumular. Outra construção inteiramente tradicional é o uso do vocativo dirigido ao passante, como Gouveia faz no verso inicial do epigrama II, 30. Mesmo sem uso do vocativo, o epigrama 17 usa de apóstrofe e supõe um passante, ao qual se dirige e que observa intrigado a "urna" de Aldo Manuzio.

Além do vocabulário e da ambientação sepulcral, o elemento comum que nos fez propor um elo entre os epigramas foi a menção alegórica a virtudes, que acompanhariam o defunto após a morte. Essas virtudes foram escolhidas por Gouveia de acordo com a figura a ser homenageada. No caso de Jean D'Yberrola, senador de Bordeaux, o poeta escolheu Fortuna, Scientia e Virtus, três qualidades condizentes com a posição e o papel social de Yberrola, que, além de senador, era um erudito protetor da universidade local. Como já se observou nos poemas laudatórios, a atribuição das qualidades se dá logo no início da composição. Nesse epigrama, a homenagem é enfatizada pela repetição, no verso 3, das mesmas palavras (na refacção de 1540, Gouveia suprime a reiteração). Quanto a Jean Albert, abade francês, escritor e estudioso humanista, o poeta recorre à mitologia, relacionando o 
homenageado às Musas (pela antonomásia doctae Sorores), às Graças e à Devoção (Pietas). No caso de Aldo Manuzio, editor e humanista consagrado, Gouveia ressalta seu lavor principal ao relacioná-lo com as nove Musas.

Nos três epigramas, Antônio de Gouveia propõe como questão se essas qualidades, então personificadas, vão acompanhá-los na morte. A resposta a essa questão é muito diferente em cada epigrama. Deixemos de lado, por ora, os epigramas I, 5 e II, 30, que jogam com a idéia do túmulo exíguo, e passemos ao epigrama 17. Neste, a resposta é uma forma de enaltecer a atividade que tornou Manuzio conhecido: a correção e publicação de textos clássicos. Por isso, imagina Gouveia, as musas não se encontram enterradas com Manuzio, pois todo o esforço do humanista italiano foi para preservá-las intocadas. Sendo assim, como ele não foi nem escritor nem poeta, não faz sentido que as musas sejam enterradas com ele, pois ele não se imortalizou pelas próprias obras literárias; mas, ao mesmo tempo, por ser o maior editor de sua época, ele permitiu a imortalidade das obras e dos autores publicados por sua casa tipográfica.

Já os epigramas I, 5 e II, 30 têm um mesmo ponto de partida de composição: a idéia do túmulo exíguo, isto é, um túmulo acanhado demais para a grandeza moral e espiritual dos retratados. De modo curioso, a questão de sabermos se esse túmulo acolhe ou não as virtudes que acompanhavam em vida as personalidades tratadas vai receber uma solução oposta em cada um dos dois poemas. No epigrama I, 5, Gouveia afirma que as virtudes não puderam caber em túmulo tão diminuto, e é somente devido a isso que ainda temos (e teremos) a lembrança do que sejam Fortuna, Scientia e Virtus. Já no epigrama II, 30, Gouveia dá a resposta contrária: apesar do túmulo ser diminuto, ele pode abrigar as musas, as graças e a piedade, uma vez que abrigou Jean Albert. É curioso como, usando um mesmo artifício, Gouveia consegue homenagear a memória de duas personalidades da época, ainda que tenha proposto saídas opostas em seus poemas. De todo modo, os epigramas prestam uma clara homenagem por meio de duas mensagens semelhantes: uma explícita, a de que os retratados sempre tiveram junto de si as qualidades atribuídas nos versos, e outra, implícita, a de que seus túmulos não refletem a grandeza desses homens. Quanto às conclusões opostas, resta observar que talvez haja alguma relação entre as escolhas de Gouveia e a profissão de cada um dos homenageados: assim, no caso de Jean Albert, prior de convento, a permanência post mortem das virtudes que o acompanhavam em vida tem alguma ligação com seu papel religioso e sua experiência espiritual, ao passo que, no poema de Yberrola, homem do Parlamento, o humanista português aproveita para fazer uma reflexão, no segundo dístico, 
sobre a memória coletiva que preserva a reputação de cada grande homem e que mantém ativos os valores sociais e morais.

Depois de todos os comentários acima, chega a ser desnecessário reafirmar a evidente presença clássica na obra de Antônio de Gouveia, que não se limita a citar um ou outro verso de autores antigos, mas compõe segundo os mesmos princípios visíveis no repertório canônico da Antigüidade.

Sendo assim, tratemos agora dos epigramas amorosos. Como dito anteriormente, eles podem ser divididos em epigramas de louvor a Catherine (composições que foram excluídas da versão de 1540), epigramas que expressam a sensação amorosa do poeta e, finalmente, epigramas que não se relacionam diretamente com o amor de Gouveia por Catherine, mas antes tratam de temas amorosos.

Dois interessantes exemplares de epigrama de louvor a Catherine são os de número 23 e 56 do livro I (edição de 1539). Os dois poemas estão relacionados, pois neles, como veremos a seguir, o poeta exalta a mulher amada e a coloca num patamar de superioridade, sem rivais no mundo terreno.

\section{AD CATHARINAM BOFREMONTANAM}

Sint tibi, sint quamuis, nullae uirtutibus, alto

Iudicio, antiqua nobilitate pares,

Nil mirum: tibi quae summi tribuere Deorum

Quis, Catharina, potest, aut petere, aut capere?

[56]

\section{AD CATHARINAM BOFREMONTANAM}

Te quaeso primam specie uirtutis in omni

Quis dicat, cum sit nulla secunda tibi? 
Os dois poemas têm uma série de elementos comuns em sua construção, a começar pelo uso de uma pergunta retórica que determina o esqueleto da composição. $\mathrm{Na}$ verdade, o epigrama 56, mais curto, é todo ele uma pergunta retórica em dois versos, anunciada pelo verbo quaeso, ao passo que o epigrama 23, com quatro versos, usa o primeiro dístico para preparar a pergunta, que ocupa o dístico final. É de notar que o pronome interrogativo empregado, "quis", é o mesmo nas duas peças, e ocupa exatamente a mesma posição enfática, a saber, a primeira palavra do verso final. A pergunta tem a intenção de supervalorizar Catherine e afastar qualquer possível rival de um espaço de comparação.

Não é à toa, por isso, que outro ponto em comum seja a presença do pronome nullus, na forma feminina (nullae no epigr. 23; nulla no epigr. 56). Essa é uma palavra-chave, pois se presta a declarar a inexistência de rivais para Catherine. A importância é enfatizada pela posição que ocupam no verso: em ambos os registros, o pronome surge após a principal cesura do verso, na abertura do segundo hemistíquio. No epigrama 23, o pronome "nullae" vem reforçado pelo emprego reiterado do verbo "sint" (regido por nullae, sujeito) e pelo contraste entre a sonoridade em /i/ do primeiro cólon do verso e a vogal tônica /u/ dessa palavra. No caso do epigrama 56, a posição relevante de nulla também recebe um duplo reforço: de um lado, no plano da sonoridade, há a amplificação provocada pela assonância em /u/ de "nulla secunda"62 (antecipada pelo /u/ de "cum"); de outro, no plano da disposição, há a oposição entre "te primam”, que ocupa o primeiro cólon do primeiro verso, antes da cesura pentemímere, e "nulla secunda", que ocupa a segunda metade do segundo verso, num choque proposital, que, no plano do pensamento, dá ensejo à antítese "primam x secunda".

Outro elemento comum é o uso do pronome pessoal da segunda pessoa. No epigrama 23, o pronome de referência a Catherine ganha saliência pela repetição da forma "tibi". No epigrama 56, o realce é ainda maior, pois o pronome, em diptoto (te, tibi), ocupa, estrategicamente, a primeira e a última posições da peça, fazendo com que Catherine, no plano da disposição, ocupe todo o poema, numa abrangência que reafirma a idéia gouveiana de que só ela existe no mundo todo, e mais nenhuma mulher chega sequer a seus pés. Note-se que, da maneira como Gouveia dispõe os pronomes, Catherine (por eles representada) abraça e contém a expressão "specie uirtutis in omni", assim transferindo à mulher amada toda a perfeição existente.

\footnotetext{
${ }^{62}$ Note-se como a assonância dá coesão ao sintagma "nulla secunda", que flui em duas homodinias.
} 
Além desses pontos em comum com o epigrama 56, o epigrama 23 tem alguns elementos particulares, que já foram vistos e comentados, entretanto, em outros poemas anteriores, notadamente nos laudatórios. Um exemplo disso se dá na distribuição das idéias no poema, pois o epigrama 23, assim como muitos panegíricos gouveianos, concentra os elogios logo no início do poema. Com efeito, a menção às qualidades de Catherine (uirtutibus, alto iudicio, antiqua nobilitate) se encontra no primeiro dístico do poema, antes (e como preparação) da pergunta retórica que ocupa o segundo dístico. Outro aspecto já comentado anteriormente é o uso do vocativo, que aparece, neste poema, no último verso, ajudando a destacar o pronome interrogativo "quis" e reforçando o apego do poeta à mulher amada. Por fim, o uso de "deorum" como palavra final do terceiro verso, posição extremamente enfática e, ao mesmo tempo, inteiramente tradicional $^{63}$, se enquadra na atitude de divinização da pessoa elogiada, comum nos textos demonstrativos.

Essa lembrança do processo de divinização da figura retratada nos remete a um ciclo de epigramas amorosos em que Gouveia, dirigindo-se a Catherine, compara a mulher amada com uma deusa, ou mesmo insinua que ela é uma deusa. Assim, optamos por usar esse critério para estabelecer mais uma cadeia de epigramas, que será analisada a seguir, composta pelos epigramas I, 40; I, 53; II, 17; e II, 33. Todos os quatro são de 1539 (uma vez que, como já foi mencionado, Gouveia retirou os epigramas abertamente elogiosos do volume de 1540).

\section{AD CATHARINAM BOFREMONTANAM}

Parce mihi, si quod mirari debeo, miror:

Amoque, officii oblitus mei.

Et facies: siquidem nulli fas dicere sisne

Diuinior, an humanior.

${ }^{63}$ A colocação de "deorum” como última palavra do verso é típica entre os autores clássicos, em parte pela possibilidade de encaixá-la, metricamente, no final do hexâmetro. Em Marcial, por exemplo, há nove registros de "deorum", e, em oito dos nove, é a palavra final. Em Ovídio, de 57 registros, em 52 é a palavra final; nas cinco exceções, “deorum” forma elisão com “est”, ou seja, mesmo nessas exceções ele é a última palavra, em locução com o verbo (“deorust”). Em Virgílio, todas as 29 aparições de “deorum” são no fim do verso. Isso demonstra o perfeito conhecimento que Antônio de Gouveia tinha da poesia clássica. 


\section{AD CATHARINAM BOFREMONTANAM}

Saepius ardenti per laudes ire tuorum,

Perque tuas, titubat si, Catharina, manus,

Culpa tua est: siqua esse potest in Numine culpa:

Ingenium uati surripis omne tuo.

\section{DEARVM INVIDIA}

Videre, et Catharina tibi inuidere puellae

Tres diuae, Iuno, Pallas et alma Venus.

Sic indignantes secum, dirumque frementes,

Ante Iouem posito procubuere genu.

Hic Iuno, ante alias, medio interfata dolore est,

Singultu tremulos excutiente sonos.

Iuno impertit opes, et Iuno impertit honores?

Fabula. ab humanis sumere Iuno potest.

Tum Venus, o Genitor, Diuas quae uicit in Ida,

Humana ut forma sit modo uicta Venus?

At Pallas, quid me cerebro genuisse necesse,

Pallada si possunt foemina uirque dare?

Iuppiter hic, tales aliam genuisse parentes

Non potuere: tamen non genuere Deam.

\section{AD CATHARINAM BOFREMONTANAM}

Te primum ut uidi magnorum munere Diuum,

Quaerebas nomen dissimulare tuum.

Ast Amor auriculam, subito miseratus amantem,

Vellit, et admonuit nominis ipse tui. 
Haesi ecquidem, obtutum longum defixus in unum:

Deceptus tamquam, sustinuique fidem.

Quid dubitas? ait ille: Deo crede, impie, crede.

Huic ego contra, hominis nomen habere Deam?

Em relação ao processo de divinização, um aspecto comum aos quatro epigramas é a proposital incerteza com que Gouveia trata a questão. Com efeito, todos os epigramas manipulam com a dúvida acerca da verdadeira natureza de Catherine, e transmitem ao leitor essa dúvida: seria ela uma mulher ou uma deusa?

O questionamento varia muito de grau nos quatro poemas, sendo mais explícito no epigrama I, 40, em que a dúvida é preservada por meio de uma interrogativa indireta (nulli fas dicere sisne diuinior an humanior); já no epigrama II, 33, é uma interrogativa direta, num trecho em sermocinatio, que repõe a dúvida (como resposta ao Amor, que perguntava: "quid dubitas?"): "hominis nomen habere Deam?”. Assim, se no epigrama 40 a dúvida fica sem resposta, sendo impossível dizer se ela é mulher ou deusa, no epigrama 33 é o estranhamento do eu-lírico, que descobre ter nome de mulher (ou seja, descobre que seria uma mulher) aquela que ele julgava uma deusa, que deixa o leitor a meio do caminho.

Os outros dois poemas não deixam de lançar o mesmo questionamento, por trás de uma posição aparentemente mais assertiva. De fato, o leitor do epigrama I, 53 tende a aceitar que Catherine seja uma deusa, pois é assim que ela é tratada, na medida em que é identificada como numen no verso 3. Mas, de certo modo, essa afirmação se deixa contaminar pela dúvida exposta na mesma passagem, pois Gouveia escreve: "siqua esse potest in Numine culpa". Sendo assim, a prótase condicional suaviza a certeza da oração, e o verbo modal "potest" colabora para enfraquecer ainda mais a univocidade do período. No epigrama II, 17 acontece o contrário: o verso conclusivo põe na boca de Júpiter o arremate "non genuere Deam”. Mas, na verdade, todo o contexto do poema leva a considerar Catherine uma deusa, e, nesse sentido, compartilhamos da visão das deusas olímpicas, que enxergam em Catherine uma rival à altura delas.

Portanto, embora os procedimentos e as formas de desenvolvimento das composições variem, o efeito dos quatro epigramas acaba sendo o mesmo: elevar Catherine, afastá-la do plano dos simples mortais, retratá-la como uma deusa (ou, pelo menos, uma semideusa).

Uma das consequiências desse tratamento laudatório hiperbólico é o emprego, nos quatro epigramas, de termos que indicam o assombro e a perturbação que Catherine causa em 
quem a vê. Por sinal, encontram-se nessas quatro composições muitos termos relacionados ao olhar e à visão, num jogo de significações muito tradicional nos textos poéticos clássicos que falam da aparição epifânica de um ser celeste. Examinemos, portanto, essa característica dos textos.

No epigrama I, 40, temos dois registros, em poliptoto, do verbo "miror", e, no verso 2 , dois termos que indicam a perturbação do apaixonado: "amo" e "oblitus": No epigrama I, 53, não há termos relacionados ao olhar, mas há três expressões que indicam o sentimento desencontrado do amante: "ardenti" (v. 1), "titubat" (v. 2), e "ingenium surripis", como núcleo de um verso que é todo ele uma declaração dessa perturbação causada por Catherine: “ingenium uati surripis omne tuo". No epigrama II, 17, há alguns termos que indicam a visão e a beleza exterior, a começar pela figura etimológica presente desde o título (inuidia, nidere e inuidere) e terminando pelo verso 10, com o substantivo "forma"; quanto ao incômodo causado por Catherine, temos muitas palavras que dão conta dessa reação das deusas, como “inuidia" (título), “inuidere" (v. 1), "indignantes" e "frementes" (v. 3), "medio dolore” (v. 5) e todo o verso 6, "singultu tremulos excutiente sonos" (aliás, trata-se de um verso reproduzido nas cartas poéticas). No epigrama II, 33, finalmente, há o verbo "uidi", logo no primeiro verso; quanto à descrição de espanto do eu-lírico, embora esse sentimento de torpor tenha sido causado pela notícia dada pelo Amor acerca do nome da amada, é claro que a sensação tem sua relação com a identidade indefinível de Catherine, pelo que cabe mencionar os termos do verso 5, "haesi ecquidem, obtutum longum defixus in unum", e o verbo "dubitas", já citado, que se encontra no verso 7. Tantos exemplos citados acima dão conta de como Gouveia trata o tema da surpresa e do encantamento causados pela visão da mulher amada.

Há ainda outras características que, se não definem a série de epigramas como um todo, perpassam mais de um poema. Um exemplo disso é o uso do pronome " $t u$ ", elemento já tratado antes. Neste ciclo de quatro epigramas, o pronome aparece empregado no epigrama I, 53, onde surge quatro vezes, uma em cada verso, em poliptoto (tuorum, tuas, tua, tuo); no epigrama II, 17, uma vez, logo no primeiro verso (tibi), antes de o poeta dar lugar ao diálogo entre as deusas e Júpiter; e no epigrama II, 33, três vezes, também em poliptoto, com "te" (primeira palavra do epigrama, v. 1), "tuum" (v. 2, última palavra do dístico) e "tui" (v. 4, também em final de dístico). Veja-se como a ênfase desejada é obtida meticulosamente pelo posicionamento topicalizado do pronome. 
Também a sonoridade ajuda a realçar o pronome, como se nota mais nitidamente no epigrama I, 53, em que a reiterada aliteração da consoante /t/ multiplica a força e presença do pronome de segunda pessoa.

Curiosamente, o epigrama I, 40 apresenta uma inovação no tocante ao emprego do pronome pessoal e possessivo: em lugar da ênfase na segunda pessoa, temos uma ênfase na primeira pessoa, pelo emprego dos pronomes mihi e mei, no primeiro dístico, realçando o sentimento do eu-lírico. O par de pronomes também é enfatizado no plano sonoro, pela aliteração do /m"/ que estabelece a forte coesão entre mihi, mirari, miror, amo e mei, num conjunto expressivo de termos referentes ao eu-lírico.

Já que falamos do plano da sonoridade, é possível verificar como Gouveia elabora com cuidado a melodia de cada poema, especialmente por meio da aliteração, mas deixa cada composição com um aspecto diferenciado, resultado de intencionalidades diferentes em cada peça. Assim, se o epigrama I, 40, ao ressaltar o pronome de primeira pessoa, apela para a aliteração do $/ \mathrm{m} /$ e se o epigrama I, 53, privilegiando a segunda pessoa, abusa da aliteração do /t/, então o epigrama II, 33 se serve de aliterações de $/ \mathrm{m} / \mathrm{e} / \mathrm{n} /$, inclusive em jogos paronomásticos, do primeiro ao último verso, como que para amplificar a palavra central do texto, que é "nomen". Nesse sentido, observe-se a paronomásia "hominis nomen", que arremata o poema. No poema II, 17, enfim, o que mais se nota é a figura etimológica "uidere / inuidere", do primeiro verso, que é retomada, por paronomásia, com o substantivo diuae, do segundo verso.

Outro recurso, presente em dois dos quatro epigramas, é a sermocinatio, com o diálogo a ocupar trechos substanciais dos epigramas II, 17 e II, 33.

Começamos a análise desse ciclo de epigramas falando do processo de divinização. Não poderíamos deixar de apontar, nesse sentido, que são exatamente esses dois epigramas com trechos dialogados que trazem figuras de deuses e estão repletos de vocabulário referente a divindades. Sem dúvida, essa representação em etopéia dos deuses auxilia, por transferência, no referido processo de elevação e divinização da mulher amada.

Acabamos de ver variados poemas cujo foco é Catherine e cuja intenção é louvar a figura amada. Entretanto, uma outra porção importante dos epigramas amorosos compostos por Gouveia trata principalmente da sensação amorosa do poeta; dentre estes, três já foram 
analisados anteriormente: a tradução que Gouveia fez de um poema de Clément Marot (epigr. I, 12), a respeito da sensação de ser atingido por uma "neve quente", expressão petrarquiana da paixão amorosa; e os epigramas 40 e 53, do livro I, de 1539, dentro do ciclo de epigramas sobre o dilema "mulher-deusa" acerca de Catherine, que accabou de ser visto. Além deles, selecionamos para examinar os poemas 55 e 96, do livro de 1540, que estabelecem um interessante elo intratextual com as cartas poéticas, publicadas na parte final do mesmo volume.

\section{CATHARINAE}

Si quaeris Lugdunensi quid agamus in urbe,

Teque etiam nostri tangere cura potest,

Conqueror ignauam luci succedere noctem,

Humecto lacrymis, decipioque diem.

At lacrymis crudelis Amor non uincitur ullis:

E media cuius edita Mater aqua.

\section{CATHARINAE}

Alma faue dixi gemini Dea mater amoris:

Respexit uatem casta Diana suum.

Obstupui, Diuaeque manus cum uoce tetendi,

Sum Dea, sum casti miles amoris ego.

Illa nihil, subitoque, oculos auersa, refugit.

Hem, nequedum miseret te Catharina mei?

Vrar ego? moriar prudensque, sciensque, uidensque?

Sitque mihi uitae consuluisse nefas?

Alguns motivos fazem desses dois epigramas uma antecipação da poesia elegíaca, sob forma de epístolas, que Antônio de Gouveia apresentará a seguir, no mesmo livro de 1540. O 
tema, o tom, o tratamento e o vocabulário são similares. Mais do que isso, Gouveia antecipa, nesses dois poemas, versos das cartas, por meio de alusões perfeitamente identificáveis.

Passemos em exame os dois epigramas. O de número 55 explica a Catherine o que o poeta faz em Lyon, como continua a amá-la, mesmo à distância, e esclarece com agudeza epigramática por que continua sofrendo e suas lágrimas não comovem o Amor: sua mãe provém da água, esta é a natureza do amor. Com exceção do verso conclusivo, que traz um arremate sagaz, surpreendente e inusitado, próprio da poesia epigramática, todo o assunto se desenvolve de modo idêntico ao das cartas poéticas, sobretudo a primeira, a terceira e a quarta epístolas (nelas, Gouveia apresenta a Catherine as mesmas justificativas acerca da distância e as mesmas declarações de amor eterno e sofrido), revestindo-se, como se vê, do mesmos princípios da poesia elegíaca. Aliás, a própria referência à água é reconhecida como ícone da elegia, por oposição ao vinho da lírica.

No primeiro dístico do epigrama, Gouveia antecipa o tratamento da primeira, segunda e terceira cartas, nas quais imagina as preocupações que Catherine teria acerca da vida dele distante dela, em Lyon. O segundo dístico não apenas se aproxima da terceira epístola, na qual Gouveia expõe seu sofrimento diário, mas efetivamente compartilha o mesmo dístico formado pelos versos 71 e 72 , como se pode verificar a seguir:

Conquerimur tardos nocti succedere soles,

Decipimus lacrimis eximimusque dies.

Assim como nas alusões aos poetas clássicos, também aqui Gouveia fez uma série visível de reelaborações e reconstruções, mesmo quando mantém o vocabulário, mudando, por exemplo, o número dos verbos ("conqueror" passa a "conquerimur", "decipio" a “decipimus") ou do substantivo (“diem" passa a "dies”).

Já no quinto verso, que abre o último dístico, podemos perceber a convergência com a quarta epístola, em que Gouveia se despede de Catherine e derrama seus maiores sofrimentos: o primeiro hemistíquio do verso é reelaborado nessa carta, que tem, no verso 21 , a mesma expressão "crudelis Amor"

\footnotetext{
${ }^{64}$ Vide verso 21, Ep. IV: “Nec crudelis amor, quis enim puer ille fuisset?".
} 
O vocabulário do epigrama 55 é típico do padecimento elegíaco: temos desde "tangere cura", no verso 2, até "lacrimis crudelis Amor", no verso 5, passando pelo homeoptoto verbal de "conqueror", "humecto" e "decipio", no dístico central, que, por meio desses três verbos na primeira pessoa do singular, em orações coordenadas aditivas justapostas, dão conta do sofrimento amoroso do eu-lírico. A amplificação da angústia se dá, ainda, pela repetição de "lacrimis"; note-se que o poeta teve a preocupação, ao repetir a palavra ipsis litteris, de alterar o caso, passando de ablativo a dativo.

O epigrama 96 tem muitos pontos semelhantes: a mesma declaração de sofrimento, o mesmo apelo aos deuses eróticos (Vênus, Amor e Cupido), o mesmo desespero fatalista. O tom do epigrama induz a uma aproximação com a epístola quatro, cujo verso 19, aliás, faz uma alusão ao verso 7 do epigrama, como se vê:

Non morerer, Catharina, sciensque, uidensque: fuisses

Por sinal, o último dístico do epigrama 96, em lugar de características próprias de seu gênero, assume inteiramente o protocolo do gênero elegíaco ao expressar o sofrimento amoroso extremo: uso duplo, em diptoto, do pronome pessoal da primeira pessoa (ego, mihi), uso de verbos descritivos de dor, paixão e desespero (urar, moriar) e interdição da possibilidade de viver (já antecipada em "moriar", agora reforçada pela identificação de "uitae" com "nefas"). Note-se que a repetição do pronome já vinha do verso anterior, com "mei” ocupando a enfática posição final. A aliteração do $/ \mathrm{m} /$, por sua vez, associa "mei" (representante do eu-lírico) com "miseret", transferindo mais carga de sofrimento ao poeta, até porque Catherine não se compadece dele.

Os dísticos iniciais do epigrama 96 também se apóiam no cânone elegíaco, como se observa em suas inúmeras menções aos deuses do amor e no lugar-comum do amante que se declara soldado do amor (miles amoris), no verso 4. Note-se que esse mesmo verso tem uma repetição muito enfática do verbo "sum", que abraça a palavra "Dea" (isto é, Vênus), como se o autor abraçasse o amor, reproduzindo, na disposição das palavras, a mesma imagem que o poeta criou no plano da representação narrativa do poema, ainda mais se levarmos em conta que, no verso anterior, ele dissera que estendeu as mãos (manus tetendi) na direção da deusa. Mas esse mesmo verso revela um maior tour de force de Gouveia, em relação à disposição das palavras, se percebermos, de um lado, que "casti amoris" envolve "miles" (ou seja, ele, soldado e militante do amor, está plenamente envolvido por um amor puro), e, de outro lado, 
que ao colocar duas referências ao eu-lírico nos extremos do verso ("sum" como primeira palavra, "ego" como última palavra do verso), o poeta apaixonado, que se encontra envolvido pelo amor, também abraça ativamente a deusa Vênus e o casto amor.

Esse mesmo poema mostra bem a consciência dos gênero literários que o humanista tinha, na referência contrastante a Diana, a deusa casta, no segundo verso do epigrama. Em outras passagens de sua obra poética, Gouveia dá a entender que começara e interrompera uma obra bucólica, para atender aos ditames do amor, que lhe impusera a poesia elegíaca. ${ }^{65}$ Nas referências a isso, Gouveia sempre associa a poesia bucólica à inspiração de Diana, em contraposição à inspiração de Cupido, no caso da poesia elegíaca, exatamente como faz no primeiro dístico do epigrama em exame. Isso sem dúvida demonstra seu cuidado na assimilação dos elementos clássicos e sua obediência aos padrões e referenciais da poesia antiga. Enfim, esses dois epigramas, ao enfocar o sentimento amoroso do eu-lírico, apresentam uma nova linha de composição, que, embora guarde elementos comuns a outros epigramas, se aproxima mais das cartas poéticas e do gênero elegíaco. Além do mais, por todas as referências intertextuais e intratextuais, podemos confirmar quanto a obra de Gouveia tem de planejamento, elaboração, convencionalismo e refinamento, mesmo que se proponha a ter uma aparência de um derramento desesperado de sensações amorosas, um cri $d u$ coeur sentimental.

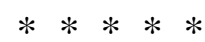

Vimos acima o exame de dois subtipos diferentes de epigramas amorosos gouveianos: aqueles centrados no elogio a Catherine e aqueles embasados no sentimento do poeta. Antes de prosseguirmos e passarmos a outro subgrupo temático da poesia ligeira amorosa de Antônio de Gouveia, gostaríamos de abordar um poema muito bem composto, que consegue amalgamar os dois subgrupos apresentados acima, enfocando simultaneamente os méritos da mulher amada, a serem elevados, e os sentimentos do eu-lírico, a serem declarados: trata-se do epigrama II, 28, publicado em 1539.

\section{AD CATHARINAM BOFREMONTANAM}

\footnotetext{
${ }^{65}$ Por exemplo, os epigramas 74, 96 e 99, de 1540, segundo nossa interpretação.
} 
Vincis me ingenio, lepore, forma,

Vincis nobilitate, uincis omni

Virtutum genere omnium optimarum:

Vincis, non nego, nec negare possum:

Ignorant sed amor meus fidesque

Vinci: et sola mouent rebellionem.

Esse epigrama detém esta singularidade: falar tanto da mulher amada quanto do homem amante. Para isso, o poeta distribui seus objetivos em duas partes da composição. Nos primeiros quatro versos predomina o louvor a Catherine, e nos dois versos finais Gouveia expõe seus sentimentos. Nesse sentido, mesmo sendo composto em hendecassílabos falécios, Gouveia se deixa contaminar pela estrutura do dístico, e percebemos que os seis versos se reagrupam dois a dois. Os dois últimos versos equivalem ao dístico final de um epigrama, com a conclusão surpreendente e contrastante com os dois "dísticos" iniciais, que funcionam como preparação.

Como ocorre com freqüência nos panegíricos, os elogios se concentram no início do poema: neste caso, não há adjetivos, mas um acúmulo de substantivos que indicam as qualidades da pessoa homenageada: ingenio, lepore, forma e nobilitate ocupam os dois primeiros versos, havendo uma ampla suma de qualidades no terceiro verso (anunciada pelo termo "omni", no final do segundo verso): “omni uirtutum genere omnium optimarum". A hipérbole é montada com o redobro de omnis (em diptoto, omni e omnium) e com o adjetivo no grau superlativo optimarum.

O elemento que estabelece a coesão entre os quatro versos é a anáfora, pela repetição de "uincis". Esse termo inicia os dois primeiros versos, bem como o quarto. No segundo verso, ele aparece duas vezes, e o segundo registro se liga, sintaticamente, ao período do terceiro verso. Não bastasse o enjambement, que vincula "uincis" ao terceiro verso, Gouveia toma o cuidado de não interromper a série inicial dos quatro versos, e coloca "uirtutum" como primeira palavra do terceiro verso. O efeito disso é a manutenção, em termos sonoros, da anáfora nos quatro versos, pela reiteração da sílaba "ui”".

Em resposta aos elogios do trecho inicial, Gouveia passa a falar de seus sentimentos: essa transição foi preparada no quarto verso, em que os verbos na segunda pessoa do singular dão lugar a dois verbos em primeira pessoa: "nego" e "possum". Mas, no quinto verso, não é o eu-lírico que aparece como sujeito dos verbos: estes passam a ser conjugados na terceira 
pessoa do plural, tendo como sujeito os sentimentos do poeta; "amor" e "fides" é que passam a reger os verbos, primeiro formando um sujeito composto claro, depois retomados pelo pronome illa. São seus sentimentos, supervalorizados, que tomam a dianteira e sozinhos (sola) promovem uma rebelião (mouent rebellionem). O detalhe mais engenhoso da inversão desse desequilíbrio entre a mulher amada, extremamente elevada perante um homem submisso (recorde-se que o verbo escolhido foi "uincis", mostrando não apenas o enaltecimento da mulher, mas o rebaixamento do homem), e os sentimentos desse amante subjugado, é que tal inversão se dá por uma correspondente inversão na voz do verbo "uinco, uincere". Isso torna a palavra "uinci" extremamente importante dentro do poema, pois ela concentra toda a carga semântica da inusitada inversão, sustenta toda a estrutura do poema e é responsável pela conclusão aguda do epigrama. Outra virtude do termo é que ele retoma a sonoridade anafórica dos versos iniciais, intensificando a coesão do poema.

$$
* * * * *
$$

Como havia sido dito anteriormente, os epigramas amorosos de Antônio de Gouveia comportam ainda um terceiro subgrupo temático: o dos poemas que não têm relação com Catherine, mas somente falam do amor. Dentre as peças independentes da figura de Catherine, uma tradução feita por Gouveia é útil para ilustrar os recursos de composição empregados por ele: trata-se do epigrama I, 32, publicado em 1539, que verte para o latim um poema em francês de Jacques de Beaune; o texto do original não é conhecido.

\section{E GALLICIS IACOBI BELNAEI}

Forte locum horroris plenum uariique timoris

Et Mors et penna praepete uenit Amor.

Dum trepidant animis, ignita Cupidinis arma

Mors capit, et Mortis frigida tela Puer.

Hinc enata lues nostros irrepsit in annos:

Hinc amat ipse senex, hinc perit omnis amans.

Os poemas desse subgrupo costumam trazer alguma reflexão sobre a condição amorosa. É bem o que se encontra neste epigrama, que pondera sobre o amor senil e sobre 
paixão. O verso final traz a conclusão, calcada sobre um trocadilho, a saber, o homem velho, mesmo no fim da vida, ainda ama; e o amor, devido ao sofrimento que causa, conduz o amante ao fim da vida. Por outras palavras: se o velho ama, também o amor envelhece.

A construção do poema recorre a alguns elementos tradicionais, que já encontramos, inclusive, em outros epigramas de Gouveia, a começar pelo dístico elegíaco, em que o poeta português compõe a grande maioria de seus versos.

Outro aspecto já várias vezes visto, preferencial em Gouveia, é a estrutura dicotômica, recheada de antíteses. O poeta forja diversos pares simétricos, tanto de elementos equivalentes, como "horroris / timoris" (v. 1, ainda por cima com homeoteleuto) e "arma / tela" (vv. 2 e 3), quanto antitéticos, como "Mors / Amor" (v. 2), "ignita / frigida" (vv. 3 e 4), "Cupidinis / Mortis" (vv. 3 e 4) e "Mors / Amor" (v. 4). Nesse sentido, o verso final é um primor do paralelismo: temos a repetição de "hinc" (cabendo notar que a estrutura dúplice do dístico final é pontuada pela anáfora de "hinc" no início dos dois versos finais), um par verbal ("amat" e "perit", a princípio antitético, mas que o poeta aproxima habilmente ao longo do poema), um par de adjuntos ("ipse" e "omnis") e um par de substantivos ("senex" e "amans"), núcleos de sujeito, mais uma vez com o valor antitético reduzido pela argúcia da composição. Simultaneamente, Gouveia constrói mais duas relações parelhas: "amat" e "amans", paronomásia por figura etimológica; e “ipse" e "perit", pela sonoridade, também paronomástica e aliterante, e pela carga semântica.

Mesmo as palavras que não entram nesse jogo de pensamentos paradoxais são dispostas em dupla por Gouveia. É o caso de "locum / plenum" (v. 1, com apoio na sonoridade), "penna / praepete" (v. 2, com aliteração), "enata / lues" (v. 5) e "nostros / annos" (v. 5).

Outra característica marcante do poema, freqüente nos epigramas amorosos de Gouveia, como já visto, é a prosopopéia, com a personificação de Amor e Morte, conforme a representação mitológica tradicional. Se a palavra Mors surge três vezes no poema, a palavra Amor pôde ser substituída por antonomásias clássicas, como Cupido e Puer. Aliás, todo o vocabulário obedece aos preceitos canônicos, como os uso dos termos penna praepete, arma e tela, para se referir ao aparato do Amor. 
Passemos, finalmente, ao último grupo temático dos epigramas de Gouveia: os de caráter jocoso. No início da classificação, havíamos dividido este grupo de composições em quatro subgrupos: epigramas satíricos de caráter moral; epigramas de ataque a outros escritores; epigramas autocríticos, muitas vezes de teor programático e metapoético; e epigramas ligeiros em miscelânea.

Dos poemas de tom moral, selecionamos o epigrama que ataca a excessiva vaidade de Dolet, na versão de 1539 , número I, $37:^{66}$

\section{AD STEPHANVM DOLETVM}

Quid te non laudem, credo, Dolete, requiris, Id me tu melius facis.

O humanista Étienne Dolet foi figura importantíssima na Renascença francesa, adepto da Reforma e mártir das Lutas Religiosas havidas naquele país. Escritor, editor, celebrado poeta neolatino, um dos líderes do círculo literário de Lyon, Dolet era conhecido e satirizado pela extrema vaidade e se gabava de ser uma autêntica reincarnação de Cícero. Gouveia trava contato com ele por meio de Sébastien Gryphe, e, a partir daí, os dois se tornam próximos. O poeta português dedica vários epigramas a Dolet, muitos de cunho satírico, como era costumeiro entre os freqüentadores do mesmo círculo literário.

O epigrama escolhido é simples e curto, com uma estrutura de pergunta (no caso, uma interrogativa indireta) e resposta, sendo esta muito breve e pungente, plena de agudeza. Tratase do mesmo esqueleto que podemos encontrar, por exemplo, em Catulo, no célebre poema 85 (odi et amo), que, por sinal, também finaliza o primeiro verso com o verbo "requiris". "Requiris", aliás, é a última palavra do primeiro verso do primeiro livro de epigramas de Marcial $^{67}$; este poeta, grande modelo assumido de Gouveia no tocante aos epigramas, também usa com frequiência o esquema de pergunta e resposta em sua obra; o epigrama III, 98, por

${ }^{66}$ A versão de 1540, com o número 40, apresenta ligeiras diferenças, que serão discutidas no próximo capítulo.

${ }^{67}$ Esse epigrama I, 1, aliás, serve como fonte para o epigrama I, 28, que Gouveia publica em 1539 (na edição de 1540, epigr. 34), o que indica o conhecimento e a memória que Gouveia tinha dessa composição em especial. Portanto, o uso de requiris encerrando o verso já tem, aí, uma referência e um respaldo. 
exemplo, tem a mesma estrutura do poema gouveiano ora em exame, composto de somente um único dístico, com pergunta e resposta, e termina o verso inicial com requiris, como se pode comparar a seguir:

Sit culus tibi quam macer, requiris?

Pedicare potes, Sabelle, culo.

Outro epigrama de Marcial, com a mesma estrutura, e também obsceno, é o de número II, 31; neste, o poeta emprega "quaeris" em lugar de "requiris". E assim se multiplicam os exemplos, como o II, 38, o II, 78, o VI, 67, etc., para ficarmos apenas nos epigramas curtos, de dois versos; pois, na verdade, como dissemos, o esquema de desenvolvimento do texto por pergunta e resposta é freqüentíssimo em Marcial.

Utilizando um esqueleto canônico, Gouveia conseguiu compor um poema muito bem feito, segundo as normas do gênero epigramático. Usando o pronome "te", de uso freqüente nos panegíricos, o poeta transfere ao interlocutor uma provável questão acerca da falta de elogios; ao pronome "te" segue-se a frase "non laudem", apresentando a essência da dúvida presumível de Dolet. A resposta é econômica e precisa em sua pungência; além disso, é construída com um eco sonoro do verso anterior, pois "quid te" é evocado por "id me", com a troca significativa de "te" por "me", isto é, a troca da segunda para a primeira pessoa, que é parte determinante da resposta. Em seguida a "id me" Gouveia coloca o pronome "tu", criando a oposição "me x tu" e adiantando a resposta, que se completa com as palavras "melius facis"; veja-se como o ataque irresistível de Gouveia se completa com o som e a disposição das palavras, pois o pronome $t u$ (Dolet) acaba cercado por dois "me", em "me tu me (lius)", ou seja, Gouveia cercou o amigo e o deixou sem saída, atacando-o naquilo que ele teria de mais reprovável.

No epigrama que acabamos de analisar, vimos Antônio de Gouveia atacar um defeito moral de um companheiro de letras; isso, de certo modo, nos remete a um outro conjunto de epigramas jocosos, em que o poeta português ataca não a personalidade, mas a qualidade literária dos colegas de seu tempo. Um exemplo desse tipo de poema é o epigrama I, 48, de 1539, de ataque direto à obra de Jean Visagier, conhecido pelo nome latinizado Vulteius, a partir de seu cognome Voulté. 


\section{AD VVLTEIVM}

Inscriptionum, non Epigrammatum libros,

Tuarum ineptiarum Amazonidem uocas.

Erras inepte, Scriptionum sunt libri.

Visagier compôs muitas obras de poesia ligeira, num estilo obviamente modelado em Marcial que lembra muito, em certas passagens, os epigramas de Gouveia. Visagier também publicou uma obra intitulada Epigrammatum Libri Quattuor, mas, neste epigrama, o alvo de Gouveia é outra obra do poeta novilatino francês, os Inscriptionum Libri Duo, publicados em 1538, em Paris.

Para tecer sua crítica, num epigrama simples, breve, ferino e objetivo, o humanista português se apóia sobretudo em três elementos. O primeiro deles, pleno de sagacidade e de erudição classicista, é nomear de "Amazonidem" a obra de Visagier; trata-se de uma alusão ao verso 8, do epigrama IV, 29, em que Marcial, discutindo o desapreço atribuído a autores de obras poéticas numerosas, usa como exemplo de má poesia a obra "Amazônide", uma amazonomaquia atribuída ao epigramatista Marso, do século I d. C., que seria excessivamente extensa e sem nenhum valor poético. A menção cai como uma luva em Visagier, que publicou numerosos livros de poesia neolatina.

Assim, Gouveia critica Visagier usando, como arma, uma palavra extraída da obra do mestre de ambos; é como se ele conseguisse instigar o professor contra o aluno, fazendo com que não ele, um colega, mas o próprio mestre formulasse o ataque. Não somente Gouveia respaldou seu ataque no repertório clássico, mas, mais do que isso, conseguiu a proeza de fazer o próprio autor clássico, imitado por Visagier, menosprezar e repudiar a imitação.

O segundo pilar da composição é o trocadilho entre Inscriptionum, palavra que abre o poema, e Scriptionum, que pertence ao verso conclusivo. Assim, com o desenvolvimento do epigrama, Gouveia consegue transformar o livro de Visagier, intitulado Inscriptionum Libri ("Livro de Inscrições"), num "Livro de Escritos ou Escrevinhações" (Scriptionum Libri), isto é, meros registros escritos, retirando-lhes, mais uma vez, todo o valor literário.

O terceiro suporte do epigrama é o uso reiterado de ineptiarum e inepte, dois termos cognatos, que se prendem a ineptus, isto é, o não-apto, inadequado, inconveniente, incompetente, incapaz, inábil, despreparado, tolo, desarticulado. Portanto, ao usar duas vezes esses termos, Gouveia desqualifica a obra de Visagier naquilo que o epigrama tem como sua 
virtude essencial: faltaria ao francês a agudeza própria do gênero, faltariam a inteligência e o refinamento literário.

Além desses três elementos fundamentais, todo o epigrama é construído metodicamente, o que é de esperar num texto que critica o fazer poético de um colega de letras. Nesse sentido, podemos constatar que Gouveia buscou, sobretudo, o equilíbrio e o paralelismo dos termos, que pode ser notado nos pareamentos "Inscriptionum / Epigrammatum” (repetição em homeoptoto, desdenhando a latinização do termo grego equivalente, muito mais usual e canônica), "libros / libri" (repetição em poliptoto, reforçada pela posição similar, epifórica, em fim de verso), "tuarum / ineptiarum" (repetição em homeoptoto, reforçada pelo homeoteleuto) e "uocas / erras" (repetição em homeoptoto, reforçada pela sucessão em anadiplose). Como se vê, todo o poema, apesar da brevidade e aparente simplicidade, é resultado de um trabalho artístico em que cada elemento foi meticulosamente premeditado, dentro dos mais tradicionais princípios clássicos.

$* * * * *$

Esse epigrama de ataque à obra de um companheiro da comunidade literária guarda muita semelhança com todo um conjunto de poemas em que Gouveia ataca a sim mesmo, depreciando sua própria obra e, ao mesmo tempo, lançando os contornos programáticos de sua atividade literária. A quantidade e o teor relativamente homogêneo desse tipo de composição permitiu-nos agrupar essas peças num subgrupo bem definido da epigramática jocosa gouveiana, sob a rubrica de poemas metapoéticos, seja pelo tom autocrítico, seja pelo caráter programático. Dentre tais epigramas, selecionamos os seguintes dois exemplares, que compartilham alguns elementos importantes, concernentes a esse subgênero e à similar estratégia de gracejo. São eles os epigramas II, 8, de 1539, dedicado a Mellin de Saint-Gelais, e 46, de 1540, em que o livro assume a voz poética e se dirige ao leitor:

\section{AD MELLINVM SANGELASIVM}

Nostros, Sangelasi, tibi libellos,

Libellos breuitate singulari

Commendo, exiguis licet, uidebis

Conclusum genus omne ineptiarum. 


\section{LECTORI LIBELLVS}

Sum breuis: hac una spero uirtute placere.

Est uitii Lector cum breuitate minus.

Nos epigramas metapoéticos de Gouveia prevalece a discussão dos principais pontos característicos do gênero epigramático, notadamente dos dois elementos principais, que configuram a essência do epigrama, a saber, a brevidade e a agudeza.

Podemos confirmar isso nos dois poemas selecionados. A menção à brevidade, aliás, é realçada em ambos. No epigrama a Saint-Gelais, temos a ocorrência de libellos (com repetição enfática em anadiplose), breuitate (v. 2) e exiguis (v. 3). "Libellus" também aparece no título do epigrama 46, em que há a figura etimológica formada pela ocorrência de breuis (v. 1) retomada em breuitate (v. 2). Esses termos, por si mesmos já tão expressivos, são amplificados por palavras vizinhas. No caso do epigrama II, 8, a palavra "singulari", que qualifica "breuitate", embora tenha o sentido de "peculiar, inusual", certamente contamina o substantivo com seu sentido primeiro, etimológico, ligado a simplex e ao "número um"; seu valor semântico, portanto, é o oposto de "múltiplo, amplo", e assim o adjetivo colabora como reforço do teor específico e próprio de "contenção, restrição e redução" de "breuitate". No caso do epigrama dirigido ao leitor, o vizinho de "breuitate" é o advérbio "minus", cuja carga semântica é comparável à de singulari, no sentido de indicar "redução, diminuição, restrição"; dessa forma, analogamente, "minus" reforça o termo "breuitate". Quanto a "breuis", no primeiro verso, o verbo sum, com seu caráter assertivo, sem dúvida enfatiza o adjetivo e acaba por afirmar a brevidade do livrinho, num epigrama que, por sinal, tem apenas dois versos.

Tendo salientado o caráter formal da brevidade, como virtude própria do epigrama (veja-se o uso de uirtute, no epigr. 46, v. 1), Gouveia se deterá, a seguir, em autocrítica, na falta de agudeza, inteligência e graça da sua obra, que são os valores essenciais, em termos de conteúdo, da poesia epigramática. Para isso, no epigrama a Saint-Gelais, ele recorrerá ao mesmo termo usado no ataque a Visagier, ou seja, ineptiarum. Se a palavra em si já comporta uma crítica feroz à qualidade do texto, o sintagma "genus omne ineptiarum" é acachapante e demolidor. Já no epigrama 46, o termo que indica a má qualidade do texto é "uitii", que forma uma antítese com "uirtute": a conclusão do verso é igualmente desdenhosa e trocista. O gracejo contra si mesmo é uma constante dos epigramas que pertencem a este conjunto, 
ampliando a demonstração de modéstia que acompanha a reflexão sobre a própria obra, em prefácios e posfácios. Mas, ao fazer a autocrítica, Gouveia está, na verdade, exercitando os mesmos procedimentos que dão a graça do gênero, ou seja, ao falar mal de sua capacidade satírica, Gouveia o faz de uma maneira que desmente, paradoxalmente, seu próprio veredicto, em mais uma brincadeira conveniente e decorosa dentro dos preceitos genéricos.

$\mathrm{Na}$ verdade, os dois epigramas foram compostos com os mesmos cuidados que Gouveia empregou ao longo do livro. Com efeito, além dos elementos já comentados, como as reiterações e antíteses, ou a escolha precisa e elaborada do vocabulário ("principal” e “auxiliar"), é possível apontar, no epigrama II, 8, pelo menos dois pontos: o pareamento "nostros / tibi" (revelando, mais uma vez, sua preocupação no uso significativo dos pronomes) e o eco anafórico produzido por "commendo / conclusum", no início dos versos 3 e 4. Quanto ao epigrama 46, note-se o uso determinante de "hac una" aplicado a "uirtute" e o grande quiasmo que estrutura o poema, com um " $x$ " formado pelo par "breuis / breuitate" (em amplificação dada pela figura etimológica, como já dito) em cruzamento com o par "uirtute / uitii” (em antítese), com as quatro palavras em posição absolutamente simétrica, ladeadas por um termo respectivo que estabelece o limite do verso; isto é, "breuis" é a segunda palavra do verso e "breuitate" é a penúltima, o mesmo acontecendo com "uitii" e "uirtute".

Para encerrar os comentários concernentes a estes dois últimos poemas, cabe notar dois elementos mais, do epigrama 46, ainda não comentados: o título e o verbo placere, que encerra o primeiro verso. No caso do título, Gouveia empregou um recurso tradicional no caso de epigramas metapoéticos: fazer o próprio livro (libellus) ter voz, e se dirigir diretamente ao leitor, excluindo o autor do diálogo. O próprio humanista usa dessa estratégia em outras composições. Esse deslocamento, por si só, já marca o caráter metapoético do texto. Finalmente, no caso de placere, que ocupa uma posição enfática, no fim do primeiro verso, esse verbo sinaliza a função básica da poesia ligeira e do discurso humilde, dentro da preceptiva tradicional da poética e da retórica clássicas, que é o de agradar e divertir, e, portanto, seu emprego parece muito adequado para referendar o papel programático do epigrama e explicitar as intenções do poeta, indicando, ainda, sua conformidade aos princípios clássicos de composição. 
Passemos, enfim, ao último subgrupo de poemas jocosos, a saber, um conjunto de epigramas de caráter ligeiro, sobre variados assuntos, que não se enquadram perfeitamente nas categorias anteriores, mas que, apesar da grande heterogeneidade temática, têm em comum o aspecto breve, arguto e leve da composição. Encontramos, neste conjunto diversificado, dedicatórias, gracejos metalingüísticos, descrições, reflexões filosóficas ou religiosas, narrativas com personagens mitológicas, agradecimentos, etc. Do grupo mais geral de poemas "menores", um exemplo pertinente é dado pelo epigrama I, 22, publicado em 1539, um misto de poema jocoso e laudatório, bastante descritivo, retratando o cão "Ribaud".

\section{DE RIBALDO}

Est canis huic nomen Ribaldus, amorque iocique

Cura, labor, studium, deliciaeque meae.

Ore canis patulo, maculoso tegmine, collo

Prominulo ac gracili, corpore et aure breui:

A pede lunato poples subducitur olli

Inferior triplici barba notata pilo est:

Renibus e latis tenuis se cauda profundit.

Nomen deme, uides in cane turpe nihil.

Este epigrama tem três movimentos muito nítidos. No primeiro dístico, como de costume nos poemas laudatórios, Gouveia faz o elogio da personagem retratada. Aqui, trata-se de uma extensa enumeração, com intensificação por sinonímia (amplificação afetiva), primeiramente, no verso 1, com polissíndeto em repetição epifórica (amorque iocique), e depois, no verso 2 , com um construção assindética, quebrada pela conjunção do último termo (deliciaeque meae), que retoma a mesma conjunção aditiva do verso anterior. $\mathrm{O}$ poeta não emprega adjetivos, mas um conjunto de substantivos com função qualificativa. $\mathrm{O}$ arremate do dístico, com o pronome possessivo da primeira pessoa (meae), serve para aproximar cão e poeta, o autor e o homenageado.

O segundo passo do epigrama é descritivo e envolve cinco versos, do terceiro ao sétimo. Gouveia faz um desenho vivo e detalhado do cachorro, usando ora de adjetivos de raro registro entre os antigos, como "prominulo" (v. 4) e "lunato" (v. 5), ora de locuções inspiradas nos clássicos, como "ore patulo" (v. 3), baseado no binômio "patulo ore", que 
Ovídio emprega duas vezes, nas Heróides, XVI, 56 e nas Metamorfoses, XV, 513, ou "maculoso tegmine" (v. 3), cuja fonte deve ser o cólon "maculosae tegmine", no verso I, 323 da Eneida.

A conclusão picante, característica do epigrama jocoso, se resume ao verso final, que abre com o mesmo substantivo "nomen" que aparecera no verso inicial, numa retomada coesiva, também garantida pela palavra "cane". É de notar que a dupla "nomen / cane", do verso final, está em quiasmo e em poliptoto com a dupla "canis / nomen" do verso inicial. A graça do arremate se baseia no duplo sentido do nome do cão, Ribaud, termo do francês arcaico que significava, na linguagem corrente, "vadio, malandro, libertino, devasso".

Pela análise dos epigramas e ciclos de epigramas compostos por Gouveia, tivemos a intenção de verificar o processo criativo de Antônio de Gouveia, os recursos literários empregados, as fontes clássicas utilizadas, a formação de seu estilo pessoal dentro de princípios predeterminados de composição genérica e, principalmente, expor e exemplificar uma proposta de interpretação dos poemas gouveianos que incorpora, na busca de significados, os diálogos intertextuais instituídos pelo humanista português.

Entretanto, passemos a tratar agora das cartas poéticas, isto é, do outro gênero clássico em que Gouveia compôs versos, o elegíaco.

No livro publicado em Lyon, em 1540, o poeta português incluiu, na parte final, as suas Epistolae Quattuor. Trata-se de quatro cartas poéticas, vazadas em dísticos elegíacos, apresentando em tom lamentoso o diálogo de separação de dois amantes, o próprio Gouveia e sua amada Catherine. Na primeira carta, o poeta dirige-se à mulher para, desculpando-se, lamentar sua partida e o afastamento entre ambos. A segunda carta é a resposta inflamada e raivosa de Catherine, que sofre pelo abandono. A terceira e a quarta cartas têm Gouveia como remetente: ele faz esforços para obter o perdão de Catherine e, insistindo no seu amor eterno, queixa-se da incompreensão e da ausência de resposta da amada. Como se nota, Gouveia exprime a mensagem típica do gênero elegíaco em Roma, isto é, de profunda lamentação e sofrimento amoroso.

As cartas somam ao todo 380 versos: a primeira tem 98 versos, a segunda, 72, a terceira, 106, e a quarta, 104 versos. 
A primeira carta pode ser dividida em quatro partes: do verso 1 ao 14 , há uma introdução, em que o poeta anuncia seu sofrimento e justifica sua hesitação ao escrever. A segunda parte, do verso 15 ao 36, traz dados autobiográficos trabalhados poeticamente. Do verso 32 ao 72, temos a narrativa do encontro amoroso entre ambos. Finalmente, do verso 73 ao 98, o assunto é a separação, terminando com uma jura de amor eterno por parte do eulírico.

A segunda carta, de Catherine a Gouveia, começa com o tema do perjúrio do poeta, dos versos 1 ao 14. Do 15 ao 40, apresenta-se a maldição de Catherine sobre a figura do antigo amado. Do verso 41 ao 52, temos narrativas de abandono, começando com a da própria Catherine, para espelhar-se depois em exemplos clássicos de sofrimento, que propiciam a passagem ao trecho seguinte, de expressão da dor amorosa, que ocupa os versos 53 a 64 . Finalmente, os versos 65 a 72 apresentam uma conclusão amarga, revoltada e imprecatória.

A terceira carta possui cinco partes. Na introdução, entre os versos 1 e 34, Gouveia lamenta a falta de uma resposta conciliatória da amada e o fim da relação entre ambos, discorrendo sobre o rápido esquecimento de Catherine. No segundo trecho, entre os versos 35 e 58, Gouveia fala de sua condição humilde e sem dinheiro, por ser poeta. Do verso 59 ao 68, ele discorre sobre a possível suspeita de Catherine de que ele teria um novo amor. Do verso 69 ao 92, ele repudia os motivos que teriam levado à incompreensão de Catherine e derrama seu sofrimento como poeta. A conclusão, entre os versos 93 e 106, é uma nova e definitiva declaração de amor.

A quarta e última carta também pode ser dividia em cinco partes. A curta introdução, do verso 1 ao 6, explica as circunstâncias da escrita da carta. Do 7 ao 38, Gouveia narra o episódio de sua paixão súbita por Catherine como uma ferida de Cupido. Do verso 39 ao 52, ele discute a aparente frieza e falta de comoção de Catherine. A quarta parte, entre os versos 53 e 60, trata da força do amor sobre Gouveia e prepara a conclusão da obra, que ocupa os versos 61 a 104, numa última invocação a Catherine.

Além das quatro cartas poéticas, fazem parte da obra três cartas em prosa, duas à guisa de prefácio e uma como posfácio. A primeira carta é a dedicatória da obra, dirigida a Giovanni Romano, médico oriundo da região de Cremona, na Itália, e louvado pelo poeta também com um epigrama. A segunda carta é dirigida a Catherine, numa função dupla de declaração de amor e justificativa da escolha do tema. O terceiro texto em prosa, encerrando o volume, é dirigido ao amigo Jacques de Beaune, e funciona sobretudo como explicação metapoética. 
Na abordagem da obra, e no reconhecimento da presença da literatura clássica em sua composição, podemos usar dois enfoques distintos: a observação da estrutura geral das cartas e o exame de algumas passagens em particular. Vejamos, primeiramente, o esqueleto do texto.

É evidente que o modelo inspirador das cartas poéticas é a obra Heroides, de Ovídio, como se depreende não apenas pela própria estrutura do texto, pelo assunto, pelo vocabulário ou pelo metro, mas também pelo curto encerramento e agradecimento dirigido ao amigo (e colega da comunidade literária) Jacques de Beaune, no qual Gouveia lhe pergunta: "Dic mihi uerum, num ita Ouidius?"68.

Essa escolha da fonte de sua obra não é de estranhar, uma vez que as "Heróides" serviram como modelo literário da epístola amatória no Ocidente. Adma Muhana assinala ${ }^{69}$ a presença dessa obra já no século XIII, na General Estoria, de Alfonso el Sabio, e indica ainda diversas obras da Literatura Espanhola que fazem uso desse modelo, a partir de meados do século XV. Também em Portugal encontramos exemplos de tradução de cartas no Cancioneiro Geral de Garcia de Resende. Esse uso se estende pelo século dezessete, e podemos notar que as Heroides foram imitadas largamente no Renascimento. Assim, o procedimento de Gouveia está perfeitamente inserido num movimento de valorização dessa obra de Ovídio, que, ao compor as "Heróides", forjou um modelo literário de cartas amatórias, de feição elegíaca, predominante no Renascimento.

Todavia, partindo do modelo ovidiano, Gouveia faz interessantes interferências na matriz. A referida obra de Ovídio compõe-se de vinte e uma cartas. As quinze primeiras simulam cartas de grandes mulheres da mitologia que, em situações extremadas, de abandono e sofrimento, escrevem para seus amados. As cartas XVI a XXI, por sua vez, dão início a uma ficção de troca de correspondências entre casais mitológicos. Nestas últimas seis, o homem escreve para a mulher, que lhe responde. No caso de Gouveia, é como se o poeta português inventasse uma continuação da obra de Ovídio, ou seja, é como se ele compusesse, um milênio e meio depois, as "cartas XXII e XXIII", pois, seguindo o esquema original, ele faz uma primeira carta em que se apresenta como remetente inicial, escrevendo para Catherine, que, na segunda carta, lhe responde. Dessa forma, a voz literária de Ovídio se mantém ativa, num processo de efetiva revitalização da memória poética.

\footnotetext{
68 Tradução: "Diz-me a verdade, não é assim Ovídio?”.

${ }^{69}$ Muhana, Adma. A Epopéia em Prosa Seiscentista, p. 99 et sqq.
} 
Outra inovação gouveiana reside no fato de que, diferentemente das personagens mitológicas da obra latina, temos uma personagem com correspondente no mundo real (o próprio autor). Após a segunda carta, que traz a resposta de Catherine, conforme o modelo das cartas finais das "Heróides", Gouveia faz mais uma inovação, pois cria mais duas cartas: primeiramente, faz uma tréplica a Catherine, e, finalmente, redige uma carta derradeira, também sua, na qual se queixa da incompreensão e da ausência de resposta da amada.

Outra sutil inovação gouveiana reside no fato de que a voz do eu-lírico masculino (o próprio Antônio de Gouveia) é muito mais feminina e muito mais identificada com a das heroínas das quinze primeiras cartas do que com a figura arrojada e sedutora dos três homens das últimas cartas. Aliás, o próprio Gouveia assume isso, ao afirmar, nos versos 85 a 89 da quarta carta, que irá morrer de amor e juntar suas lágrimas à das mulheres que morreram enlouquecidas pela paixão. Essa posição de Gouveia também é ratificada no verso 90, que arremata o trecho, no qual ele afirma que o sofrimento amoroso deve ser visto como a grande virtude da mulher. Portanto, a postura adotada é bem diferente daquela que encontramos nas cartas dos missivistas masculinos das Heróides, nas quais há mais apelo que lamento (sobretudo em Páris e Acôncio).

Em suma: partindo da concepção da obra ovidiana, Gouveia não só forja uma continuação, mas vai além da troca de correspondências existente nas Heróides, compondo mais duas cartas atribuídas, em caráter ficcional, a si mesmo, num tom elegíaco distinto daquele que o poeta sulmonense põe nas vozes de Páris, Leandro e Acôncio, remetentes das cartas XVI, XVIII e XX, respectivamente. De um lado, Gouveia soube buscar em Ovídio mais do que a estrutura formal e o tom elegíaco de sua obra, apropriando-se de versos, incorporando a elocução clássica, e constituindo para si mesmo um verdadeiro ethos ovidiano, dando continuidade à obra e sobrevida ao projeto literário de Ovídio. De outro lado, Gouveia soube imprimir sua marca pessoal, fazendo interferências radicais no modelo original.

Ademais, Antônio de Gouveia não se restringe, na criação poética erudita das cartas, a imitar somente as Heroides, nem tampouco somente Ovídio: outras obras do poeta sulmonense, assim como de outros autores latinos, notadamente Virgílio, têm seus versos citados ou imitados, com frequiência, no texto do escritor quinhentista.

Para verificar os procedimentos alusivos empregados por Gouveia na composição de seu texto, passemos a analisar algumas passagens selecionadas das cartas poéticas. Nessas análises, nos propomos a verificar igualmente, quando possível, as conseqüências da interferência de Gouveia na recepção e leitura dos clássicos, e as redes intertextuais mais 
amplas em que a alusão do humanista português é apenas mais um elemento de uma extensa teia de versos.

O início das cartas sinaliza a preocupação de Gouveia em fundamentar seu texto em autores clássicos, pois a composição começa recheada de alusões. Vejamos alguns exemplos.

Nos primeiros catorze versos da primeira carta, antes de se pôr a falar de sua vida, Gouveia, como foi dito acima, comenta a dificuldade de escrever e de declarar seu amor a Catherine. $\mathrm{O}$ auge da hesitação encontra-se nos versos 5 a 8 , a seguir:

Ter calamus cecidit digitis, ter uerba negauit

Musa, ter inceptos destituitque sonos

Ter conatus ego fletus cohibere, ter illi

Vberius grauidis prosiluere genis.

O pilar do trecho, sem dúvida, é a repetição do advérbio “ter”. Entre os clássicos, podemos encontrar a repetição, por duas ou, no máximo, três vezes, de ter. Ao justapor consecutivamente dois dísticos estruturados a partir da anáfora do advérbio, formando uma sequiência de cinco registros do termo, Gouveia amplifica o recurso clássico, propondo uma inovação particular em relação aos modelos preferenciais desse tipo de anáfora: Ovídio e Virgílio.

Com efeito, o uso do advérbio ter, em anáfora, é característico de Ovídio, que usa o recurso inúmeras vezes, em diferentes obras, como que "patenteando" esse emprego, de forma muito distante à de Catulo (que nem sequer usa o advérbio), Marcial, Propércio, Horácio ou Tibulo (embora estes dois últimos registrem, cada um, um único caso de construção semelhante).

Apesar de haver várias passagens ovidianas que ilustram esse emprego, parece-nos que Gouveia, no primeiro dístico, aludiu marcadamente aos seguintes versos das "Heróides" (IV, 7-8):

Ter tecum conata loqui, ter inutilis haesit Lingua, ter in primo restitit ore sonus. 
Em relação ao segundo dístico, poderíamos apontar outra passagem de contornos semelhantes, que está nas Metamorfoses, XI, 419-420:

Ter conata loqui, ter fletibus ora rigavit

Singultuque pias interrumpente querellas.

Na sua intencionalidade, Gouveia manteve o número de repetições que havia em suas fontes: três repetições no primeiro dístico, duas no segundo.

Mas o uso do advérbio ter em anáfora encontra outro cultor em Virgílio, com alguns registros parecidos com os de Ovídio. Porém, é interessante aproximar estes versos de Gouveia e de Ovídio da seguinte passagem de Virgílio, que corresponde aos versos 792-3, do segundo livro da Eneida:

Ter conatus ibi collo dare bracchia circum;

Ter frustra comprensa manus effugit imago,

Há um duplo interesse na comparação: por um lado, nota-se nos dois poetas clássicos o mesmo uso do particípio passado do verbo conor logo depois do advérbio, na segunda posição do verso; por outro lado, é notável que Virgílio tenha repetido estes dois versos, ipsis litteris, no sexto livro da mesma obra "Eneida" (versos 700-1).

No seu diálogo intertextual, é certo que Gouveia tinha em mente os versos da "Eneida", pois se serviu deles em mais uma alusão, feita no verso 3 do epigrama II, 24, publicado em $1539:^{70}$

En tellus natae collo dans brachia circum

Afinal, o que une esse xadrez de citações, em que os versos da carta poética de Antônio de Gouveia trazem à mente do leitor erudito cinco diferentes passagens, num emaranhado intertextual?

\footnotetext{
${ }^{70}$ Repetido sem alteração no epigrama 78 do mesmo volume onde se encontram as cartas, em 1540.
} 
A resposta passa pelo fato de que todos os cinco trechos mencionados narram os últimos diálogos das suas respectivas personagens; como se fosse um fio que, puxado, arrastasse atrás de si as cinco outras passagens, a circunstância da despedida patética e desesperada liga todos os outros versos aos dísticos de Gouveia. Com efeito, o referido trecho das Metamorfoses (XI, 419-420) narra o diálogo final entre Ceix e Alcione, com a fala apaixonada e desesperada da esposa; o primeiro trecho da Eneida (II, 792-3) trata da despedida de Enéias e Creusa, com a fala emocionada do fantasma da mulher; o segundo trecho (Eneida, VI, 700-701) retrata o instante de despedida do encontro de Enéias com a sombra do pai, no Hades; e o epigrama sepulcral do próprio Gouveia narra o momento da morte de Sibylle Barcy. Nos três trechos clássicos, salta aos olhos, em especial, a questão da partida do homem, que se vê compelido por obrigações e por desígnios divinos a continuar sua jornada, e abandonar o ente querido, exatamente o mesmo caráter ético que Gouveia assume para si, ao longo das quatro cartas. ${ }^{71} \mathrm{Ou}$ seja, logo no início da primeira carta, Gouveia, por alusão, reforça a dor da despedida (amplificada pelas situações referidas, todas elas irremediáveis) e investe o eu-lírico de um ethos de sacríficio e pietas (na sua identidade com os heróis retratados). Ao mesmo tempo, já prenuncia, logo no início, o desfecho da obra.

Quanto ao quinto trecho utilizado por Gouveia, os versos 7 e 8 do quarto livro das Heróides, sobre o qual o poeta modelou o primeiro dístico em questão, trata-se do início da carta de Fedra a Hipólito; portanto, a alusão, além de remeter a outra situação de amor violento e vão, em pleno desespero da separação, é apropriada e decorosa porque, no plano formal, aproxima a estrutura e o estilo dos textos. Assim, Gouveia elabora o início da carta da mesma maneira que Ovídio, com a mesma estratégia discursiva, motivando ainda mais a identificação entre os dois autores.

Feitos esses comentários sobre as referências intra e intertextuais concernentes à construção da anáfora de "ter", cabe ainda uma observação sobre o verso que encerra o trecho gouveiano em exame, isto é, o verso 8, que repetimos a seguir:

${ }^{71}$ Em relação ao fato de o epigrama sepulcral em memória de Sibylle Barcy aludir a duas diferentes passagens, nas quais Enéias tenta abraçar as imagens dos mortos, é clara a intencionalidade gouveiana, de remeter a esses episódios a situação desesperada da mãe (a Terra) que tenta abraçar a filha falecida. Gouveia cria uma aproximação entre o espírito da filha que parte para o céu e os espíritos dos entes amados de Enéias, e, simultaneamente, preenche de motivação a cena, intensificando os efeitos sobre o leitor que identifica as alusões. 
Vberius grauidis prosiluere genis.

Esse verso tem como matriz indiscutível o verso 116 do Epicedion Drusi (ou Consolatio ad Liuiam), atribuído a Ovídio:

Effusae grauidis uberibusque genis.

A alusão tem pelo menos duas funções: em termos de sentido, amplifica a dor descrita por Gouveia, reforçada pelo trecho do epicédio em que Climene chora a perda do filho Fáeton; ou seja, na aproximação dos trechos, o poeta compara suas lágrimas de amor às de uma mãe que perdeu o filho tragicamente. No plano da estrutura formal da obra, essa alusão prepara a alusão que vem a seguir, indicando a base textual sobre a qual o humanista forjou o dístico seguinte, versos 9 e 10.

Mas, antes de passarmos a esse próximo trecho, cabe notar como Gouveia esmerou-se na manipulação do material poético a que fez alusão, reelaborando-o segundo seus próprios valores estilísticos. Note-se, por exemplo, a preocupação com a sonoridade do verso 5: além da repetição anafórica interna ao verso (ter ... ter), há a aliteração em "c" (calamus cecidit), a paronomásia (cecidit digitis), o eco (ter uerba) e a repetição vocálica (uerba negauit).

Passemos agora à próxima passagem a ser comentada. Trata-se, como acabamos de anunciar, do dístico que vem logo a seguir, formado pelos versos 9 e 10. É o clímax da primeira parte da carta, quando o poeta diz que finalmente venceu a hesitação e, ainda assim entre lágrimas, se pôs a escrever:

Tandem ubi per lacrimas licuit, sed flebilis orsa est, Singultu tremulos excutiente sonos.

Para extrairmos um maior número de observações acerca do dístico, no que respeita à intertextualidade, será produtivo compará-lo com outras quatro passagens similares. A apresentação das quatro será feita em ordem crescente de semelhança, isto é, as citações partem da alusão mais tênue até a menção idêntica. 
A primeira alusão foi comentada por Katherine Zeeb, que percebeu que o verso 10 faz eco ao verso XI, 420, das "Metamorfoses", mencionado logo acima, e que voltamos a reproduzir, acompanhado do seu antecessor, verso 419:

Ter conata loqui, ter fletibus ora rigavit

Singultuque pias interrumpente querellas.

Uma segunda alusão também foi percebida por Zeeb, ao reparar que, ainda mais semelhante, é o verso I, 3, 42, dos Tristia:

Singultu medios impediente sonos.

O que escapou à observação de Zeeb, por um motivo absolutamente compreensível, dado que ela se preocupou apenas com as obras principais e autênticas de Ovídio, é que novamente no Epicedion Drusi (ou Consolatio ad Liuiam), encontramos os versos mais semelhantes, e uma inquestionável fonte do dístico gouveiano, como é possível perceber, pela seguinte citação dos versos 119 e 120 do referido poema:

Tandem ubi per lacrimas licuit, sic flebilis orsa est

Singultu medios impediente sonos:

Ademais, como Zeeb deteve-se na tradução e análise das cartas, sem examinar os epigramas, escapou-lhe o fato de que Gouveia já havia usado o mesmo verso, sem mudança alguma, no epigrama II, 17, de 1539, como se pode ver a seguir, pela reprodução dos versos 5 e 6 do referido epigrama, intitulado "Dearum Inuidia":

Hic Iuno, ante alias, medio interfata dolore est, Singultu tremulos excutiente sonos.

Portanto, com seu dístico, Gouveia teceu uma quádrupla alusão. Vejamos como o poeta reelaborou o vocabulário, de que modo interpretar o jogo intertextual e quais efeitos o humanista português obteve com esse recurso em sua obra. 
Em termos formais, verificamos que o primeiro verso do dístico foi talhado sobre o verso 119 do Epicedion Drusi, com a única troca de de "sic" por "sed", cabendo até mesmo verificar se o humanista lusitano não teve acesso, no século XVI, a um texto com essa diferença. $^{72}$

Tandem ubi per lacrimas licuit, sic flebilis orsa est (Ovídio, Epicedio, 119)

Tandem ubi per lacrimas licuit, sed flebilis orsa est (Gouveia, Ep. I, 9)

Se levarmos em consideração a ordem de publicação das cinco versões do segundo verso do dístico, diremos que, primeiro, ele foi copiado (de modo idêntico) do epigrama II, 17, do próprio Gouveia, publicado em 1539, o qual, por sua vez, havia sido forjado sobre o verso 42 do poema I, 3, dos "Tristes" (mantendo as duas palavras extremas intocadas e alterando as duas palavras internas para dois termos absolutamente correspondentes e com as mesmas características morfossintáticas). Esse verso dos Tristia, por sua vez, era também uma auto-cópia do verso 120 da "Consolação a Lívia", do próprio Ovídio. Esse verso, por sua vez, era uma auto-imitação das "Metamorfoses" do mesmo Ovídio, que manteve a mesma palavra inicial, trocou as três restantes, sempre respeitando as mesmas características morfossintáticas nas trocas, e eliminou a conjunção "que", para encurtar o verso, que passou de hexêmetro a pentâmetro.

Singultuque pias interrumpente querellas. (Ovídio, Met. XI, 420)

Singultu medios impediente sonos: (Ovídio, Epicedion, 120)

Singultu medios impediente sonos. (Ovídio, Tristia, I, 3, 42)

Singultu tremulos excutiente sonos. (Gouveia, Epigr. II, 17)

Singultu tremulos excutiente sonos. (Gouveia, Ep. I, 10)

Ainda em termos formais, é curioso notar que Gouveia usou em duas obras diferentes exatamente o mesmo verso, que havia sido modelado sobre um verso que Ovídio, por sua vez, também usara em duas obras diferentes. Trata-se de um processo de imitação que chega, assim, à minudência. Ou, por outros palavras, Gouveia faz uma auto-cópia tendo como fonte e modelo uma auto-cópia de Ovídio. Podemos concluir que Gouveia, ao perceber que Ovídio

\footnotetext{
${ }^{72}$ Não nos foi possível, até o momento, verificar essa hipótese.
} 
usara o mesmo verso em duas obras, quis seguir seu mestre (e, ao mesmo tempo, revelar ao círculo literário renascentista sua erudição e seu conhecimento da obra de Ovídio) e forjou um novo verso, nitidamente alusivo, que ele próprio veio a usar em duas obras.

Ademais, se está correta a proposta desta tese, que defende que o verso 419 (das "Metamorfoses") é a fonte principal do dístico anterior de Gouveia (versos 7 e 8), e se é certamente plausível que Gouveia tinha em mente o verso 420, ao fazer a continuação de seu poema (versos 9 e 10), ${ }^{73}$ então, mesmo que o verso 420 não seja a fonte principal do verso 10 , é, inevitavelmente, uma fonte secundária, e uma alusão mais suave. Nesse sentido, Gouveia conseguiu fazer uma amplificação dessa passagem das "Metamorfoses", de tal maneira que duplicou o texto ovidiano, isto é, transformou em dois dísticos o que originalmente eram dois versos, redistribuindo o texto de Ovídio e fazendo com que o primeiro verso (v. 419) gerasse o primeiro dístico gouveiano (vv. 7 e 8), e o segundo verso (v. 420) inspirasse o segundo dístico (vv. 9 e 10). Assim, há um escorrimento da concentração original, e Gouveia transfere a carga semântica e melódica inicialmente contida, em Ovídio, em dois versos, para dois dísticos seus, "duplicando" o texto ovidiano e amplificando, do mesmo modo, o teor lamentoso do original. Nessa mesma linha de interpretação, podemos afirmar que Gouveia cria, em conseqüência, um cruzamento de alusões, em "quiasmo", da seguinte maneira: nos versos 7 e 8, a alusão principal é o trecho das Metamorfoses, e a alusão secundária (formativa apenas do verso 8) é um verso da Consolação; nos versos 9 e 10, a alusão principal é o trecho da Consolação, e a alusão secundária (formativa apenas do verso 10) é um verso das Metamorfoses. Note-se, com isso, a que ponto chega a tecitura erudita da obra e o detalhismo de elaboração do texto.

Já entrando no plano do significado, essa múltipla alusão respalda-se na associação de sentido entre as diferentes passagens. No caso de Antônio de Gouveia, o dístico, embora se referindo ao eu-lírico, tem como sujeito verbal a sua Musa, que começa a cantar-lhe os versos, depois de um longo choro; no epigrama do próprio Gouveia, quem chora é Juno (invejosa da beleza de Catherine), que começa a se queixar a Zeus; nos Tristia, a esposa de Ovídio é quem chora, por causa do exílio do marido; no epicédio, é Lívia quem chora a perda do filho Druso; finalmente, nas Metamorfoses, como já dissemos, é Alcione quem chora a partida do marido.

${ }^{73}$ Acabamos de verificar como o verso 420 é a fonte longínqua, primitiva e, portanto, indireta, do verso 10 da carta. 
Portanto, Gouveia, pela alusão, faz sua musa incorporar a voz e os sentimentos mais intensos e mais diversos, de outras quatro figuras femininas, sendo uma deusa, duas esposas e uma mãe. Essa multifacetada referência feminina, aliás, é bastante indicativa de uma característica já apontada anteriormente, a saber, o privilégio da voz e da postura feminina na persona do eu-lírico.

O dístico seguinte, com os versos 11 e 12, encerra outra alusão. Vejamos o texto:

Aspice uerborum caecasque rudesque figuras:

Aspice quam multis multa litura locis.

Gouveia imita o verso XV, 98, das Heróides:

Aspice quam sit in hoc multa litura loco!

Note-se a capacidade de Gouveia de ampliar os efeitos presentes no verso de Ovídio e, ao mesmo tempo, pela alusão, enriquecer e expandir os sentidos de seu próprio verso. De fato, ao repetir o verbo no imperativo "aspice", duas vezes, em início de verso, ou ao repetir o adjetivo "multus", no poliptoto "multis multa", o poeta português parece redobrar a força da lamentação original. Mas, ao mesmo tempo, permite que o lamento de Safo, na carta XV das Heróides, contamine e se irradie por seu verso. Aliás, ao aludir às palavras de Safo (personagem-autora da carta), Gouveia admite provocar uma interessante identidade entre ele próprio e a poetisa. Há uma dupla identidade aqui: por um lado, com a figura de poeta, isto é, Gouveia pretende igualar-se à célebre poetisa, pôr-se como seu equivalente moderno; por outro lado, Gouveia identifica-se com a figura feminina: em outros pontos isso se repete, com o poeta assumindo a faceta feminina do lamento e do abandono, como já mencionado anteriormente.

Poucos versos à frente da passagem comentada acima, há um novo trecho que permite uma análise mais extensa das relações intertextuais ativadas por Antônio de Gouveia. Nesse excerto, que se encontra na segunda parte do primeira carta, logo após a introdução, Gouveia se apresenta e passa a relatar o roteiro de sua vida, desde o nascimento em Portugal, os 
estudos em diferentes cidades francesas, até o momento em que conhece Catherine, apaixonando-se perdidamente. Para dar conta de sua origem, escreve Gouveia, no verso 17 dessa primeira carta:

Beia mihi patria est, fuerat Pax Iulia priscis:

O primeiro hemistíquio desse verso retoma, indiscutivelmente, o terceiro verso da célebre elegia "tenerorum lusor amorum", dita "autobiográfica", a décima do quarto livro dos Tristes, em que Ovídio se apresenta para a posteridade:

Sulmo mihi patria est, gelidis uberrimus undis

Veja-se como Gouveia, ao se apropriar do verso de Ovídio, por meio da reprodução da fórmula introdutória ${ }^{74}$, incorpora a própria persona do poeta clássico, pretendendo acentuar, em si mesmo, os dois aspectos mais distintivos de Ovídio: o de ser "amante" e "exilado". Com efeito, é como homem apaixonado e distante de sua pátria que Gouveia vai se apresentando ao longo da carta. Mais do que isso, ao provocar, pela repetição da fórmula, a identidade entre ambos, Gouveia acaba por se qualificar como "poeta elegíaco", ou melhor, como um "novo Ovídio". Nesse sentido, o verso foi escolhido com precisão pelo português, pois é extraído da elegia em que, como se disse, Ovídio se apresenta para a posteridade, confiante na preservação de sua memória, através da glória duradoura de sua poesia. Há um visível paralelismo entre o trecho da carta poética novilatina e a citada elegia latina, e um constante diálogo aproximativo entre ambas. Gouveia, no desejo de imitar a poesia de Ovídio, até se apresenta como o poeta antigo, e, ao mesmo tempo, satisfaz a expectativa que Ovídio tinha de preservação de seu nome ao imitar a própria elegia em que ele expressava esse desejo.

Contudo, para acrescentar um novo elemento à análise, e deixar mais exposta a notável dinâmica da intertextualidade, devemos observar que essa mesma construção, imitada por Gouveia, é recorrente em Ovídio, uma vez que a fórmula "nome + mihi patria est", nesta ordem ou com pequenas transposições, é usada por ele mais três vezes, sendo uma na carta

\footnotetext{
${ }^{74}$ Essa fórmula tornou-se tão notória que foi adotada pela cidade de Sulmo (ou Sulmona), que passou a usar as iniciais "SMPE" como emblema do local.
} 
XX das Heróides e duas no livro quinto das Metamorfoses. Todavia, defendemos, neste trabalho, que o verso de Ovídio nos Tristes ecoa sobretudo o verso 494 do livro V das Metamorfoses, em que a ninfa Aretusa se apresenta dizendo:

Pisa mihi patria est et ab Elide ducimus ortus

Ovídio, ao se apresentar, escolhe a mesma fórmula que colocara na boca de Aretusa, propiciando, pela auto-imitação, inúmeras interpretações, das quais três são mais evidentes.

A primeira delas, de teor mais "biografista", permite relacionar a perseguição que a ninfa sofre, por parte do deus-rio Alfeu, com a perseguição que o poeta sofre por parte de César, que várias vezes é equiparado a um deus pelo próprio Ovídio, em diferentes versos das obras de exílio. Portanto, da mesma forma que a beleza inocente de Aretusa atrai para si a perseguição feroz e inesperada do deus, também Ovídio se vê alvo da fúria inclemente de um deus, como resultado impensado de sua produção poética. Ovídio com freqüência se declara inculpável. Assim, associar-se à ninfa é uma forma de mostrar que também ele sofre ao ter uma virtude transformada em causa de infortúnio.

Uma segunda interpretação cabível para a opção de Ovídio, a meu ver, seria a seguinte: assim como Aretusa é transformada em fonte que jorra água límpida permanentemente, da mesma forma o poeta Ovídio é fonte literária, que derrama para a posteridade a poesia exemplar. Ao invocar os mesmos termos de Aretusa, Ovídio também transfere para si a eternidade da ninfa-fonte.

Finalmente, Ovídio decalca em si mesmo um atributo primordial da ninfa, qual seja, o fato de ela ser uma exilada. De fato, Aretusa irá contar, nas Metamorfoses, como foi perseguida por Alfeu e como, por obra de Diana, terminou exilada na Sicília, depois de percorrer uma longa distância, por caminhos infernais, superando a distância dos mares. Ela própria se identifica como "hospita" e "peregrina". Ora, Ovídio, nas obras do exílio, faz questão de assinalar a dificuldade de sua travessia por mares longínquos, até chegar, como estrangeiro, a Tomos. Portanto, ao abordar o tema do exílio, nada mais eloqüente e poético do que se identificar com a ninfa peregrina. Vemos, assim, como a escolha de Gouveia se torna igualmente potencializada e revigorada: também o português vive como peregrino, fora de Portugal, também ele atravessou mares e terras para chegar a Bordeaux e Avignon, também ele tematiza, repetidamente, o exílio. Assim, Gouveia retoma a metáfora ovidiana, e a 
reduplica, assumindo, poeticamente, o ethos de Ovídio, da mesma maneira como o assume, prosaica e didaticamente, no posfácio.

Cabe observar a dinâmica de apropriação e refacção, em que Gouveia refaz o já refeito e se reapropria do já apropriado. Nesta dinâmica se reaviva a memória do texto e se mantém a memória do poeta. Gouveia, imitando o antigo, transfere para si os atributos do imitado, não apenas preservando uma poesia estanque, mas vivificando a poesia modelar.

Apenas dois dísticos depois, o humanista português cunha os seguintes versos, referindo-se aos três irmãos que foram estudar na França antes dele e por lá permaneceram (versos 21 e 22):

Gallia tres studiis florens ignobilis oti

Ceperat, accesi quartus et ipse tribus.

O primeiro verso do dístico alude ao epílogo das Geórgicas de Virgílio, notadamente ao verso 564:

Parthenope studiis florentem ignobilis oti

Antes de avançar numa interpretação, cabe registrar que o adjetivo ignobilis é pouquíssimo usado na poesia clássica: entre os autores mais citados por Gouveia, é notável que o adjetivo nunca tenha sido empregado por Catulo, Tibulo, Propércio ou Ovídio. É empregado duas vezes por Horácio e aparece entre os comediógrafos: em Plauto, três vezes, sendo termo hapax em Terêncio (Fórmio, 120). Disso resulta que seu utilizador mais freqüente é Virgílio: cinco vezes. Exatamente o mesmo Virgílio cujo verso foi diretamente referido.

Também convém apontar, em termos de contexto histórico, o fato de que o livro de Gouveia foi publicado durante o reinado de Francisco I, que governou os franceses de 1515 a 1547, período em que o país esteve envolvido nas guerras com a Itália, sobretudo pelo controle de Nápoles ${ }^{75}$ e de Milão. A época de Francisco I coincide com o florescimento da Renascença na França, e por um nítido contraste entre os êxitos na política interna, com certa

\footnotetext{
${ }^{75}$ Justamente a Parthenope de Virgílio.
} 
opulência na corte (em que pese alguma crise econômica) e os retumbantes fracassos na política externa, incluindo pesadas e seguidas derrotas nas guerras italianas, que talvez não tenham se refletido com mais intensidade na França pelo fato de ocorrerem, em geral, no território italiano (com exceção de algumas incursões das tropas de Carlos V na Provença). Mas, ao que tudo indica, sobretudo na década de 1530, o saldo parece ter sido muito positivo para as artes e a cultura humanística na França.

Isto posto, detenhamo-nos no adjetivo ignobilis conforme utilizado no verso 564 das Geórgicas: segundo as traduções mais reputadas, o significado do vocábulo é "ignóbil, vil, desonroso", como podemos encontrar nas traduções das coleções Belles Lettres e Loeb. O OLD indica o mesmo sentido em relação a essa passagem. A explicação disso é que Virgílio se autodeprecia diante de Augusto: enquanto o imperator romano luta vitorioso nas batalhas do Oriente, o poeta goza de um ócio pouco honroso na cidade de Nápoles. Veja-se, abaixo, todo o trecho:

Virgílio, Geórgicas, IV, 559-566:

Haec super aruorum cultu pecorumque canebam

et super arboribus, Caesar dum magnus ad altum

fulminat Euphraten bello uictorque uolentis

per populos dat iura uiamque adfectat Olympo.

illo Vergilium me tempore dulcis alebat

Parthenope studiis florentem ignobilis oti,

carmina qui lusi pastorum audaxque iuuenta,

Tityre, te patulae cecini sub tegmine fagi.

Porém, se formos transferir essa interpretação tradicional para o verso de Gouveia, estaríamos diante de uma situação melindrosa. Com efeito, o humanista português fez uma interessante uariatio in imitando, pois, em Virgílio, o particípio florentem se aplica ao próprio autor, naquilo que se convencionou denominar sphragis do poema; ao passo que, em Gouveia, florens concorda com Gallia. Sendo assim, ele estaria a dizer que a França estaria florescendo na busca (ou pelos interesses, ou nos prazeres) de um ócio ignóbil. Ora, parece difícil de aceitar que Gouveia, um estrangeiro que tenta se afirmar no círculo literário francês, tivesse a ousadia de atacar desse modo a pátria que o acolheu, tecendo uma crítica política ao 
governo do mesmo rei que é homenageado no poema de abertura do livro, num epigrama que, aliás, substituiu a igualmente elogiosa composição I, 58, do volume do ano anterior. Seria como falar que na França vicejava o esplendor de um ócio vil e desonroso. Zeeb, que identificou perfeitamente a fonte do verso, traduziu "France, flourishing in the pursuits of inglorius ease", e justificou a construção gouveiana como uma referência ao luxo ostensivo que Francisco I introduziu na corte, apesar das guerras italianas contra Carlos V. Se é possível que Virgílio se menospreze e se rebaixe perante Augusto, parece, no entanto, difícil aceitar que Gouveia menospreze e rebaixe a França, ou que critique, mesmo sutilmente, a política do mesmo rei a quem o livro é dedicado.

A intenção de Gouveia parece ser bem outra: ao evocar o epílogo das Geórgicas, o humanista faz uma interessante aproximação entre a situação do passado e aquela do presente, num hiperbólico elogio ao rei francês. Francisco I seria o equivalente de Augusto: assim como o príncipe romano foi para longe, lutar e sagrar-se vitorioso diante dos partas, o rei francês foi para longe de seu território, para derrotar os exércitos estrangeiros (fato que, na realidade, sabemos que não ocorreu). Assim como Virgílio pôde usufruir da paz instalada em sua nação para compor o poema, os intelectuais franceses puderam aproveitar o ambiente de paz e prosperidade que o rei francês proporcionou para eles. Assim, Francisco I é um novo César, que concedeu o ócio necessário à produção artística e intelectual.

É certo que, pela alusão, Gouveia reforça a idéia de que a posição de Francisco I é muito superior em glória à dos humanistas, assim como a glória de Augusto é muito superior à de Virgílio. Afinal, a glória dos campos de batalha é mais evidente do que a da literatura.

Se é assente o fato de que, pela alusão, Gouveia recriou o contraste entre a guerra e a paz, isto é, entre a glória militar e a literária, e este é o ponto fundamental a reter, creio que ainda cabe discutir o valor de ignobilis oti, e notadamente o sentido da expressão para Gouveia.

No poema de Gouveia, como dito acima, é impensável que o poeta estivesse a dizer que o rei permitiu que a França, enquanto se debatia com a guerra, esbanjasse um ócio vil e cortês. Gouveia, pela alusão, sem dúvida elevou o rei; mas não parece verossímil que fizesse isso rebaixando o país. Mais adequada parece ser a interpretação de que a França florescia nos estudos (humanísticos, os studiis bonis do verso 24) graças a uma paz e a um ambiente propício (proporcionado pelo rei, está decerto implícito), ainda que tais estudos não tivessem o mesmo reconhecimento glorioso que o proveniente da vida militar. Nesse sentido, ignobilis 
não deve ser traduzido por "vil, desonroso", mas por "menos honroso, desinteressado de louvor".

Porém, talvez caiba uma interpretação ainda mais distante da idéia de que a atividade intelectual é "desonrosa". Talvez a melhor tradução para ignobilis oti seja "paz desconhecida”. De fato, isso tornaria a passagem gouveiana extremamente engenhosa: por um lado, seria extremamente elogiosa à França e a todo o ambiente acadêmico e universitário do país, que estaria "florescendo nos estudos graças a uma paz inédita". Por outro lado, além de associar a imagem de Augusto a Francisco I, estaria a afirmar que ele trouxera para a França uma "paz nunca vista", uma pujança renascentista derivada de conquistas militares. Essa parece ser, precisamente, a interpretação mais adequada do texto.

Podemos fundamentar essa interpretação com outro elemento importante, que não tem sido muito comentado mesmo pelos estudiosos de Virgílio: trata-se da antítese entre "florentem" (florens em Gouveia) e "ignobilis". O particípio "florens" tem sentido extremamente elogioso, e muitas vezes significa "glorioso, reputado, famoso, ilustre, brilhante, destacado". Portanto, florens ocupa o mesmo campo semântico de nobilis. Assim, ignobilis, formado pelo prefixo negativo "in-" somado ao adjetivo nobilis, tem sentido exatamente oposto. A "brincadeira" de Virgílio (note-se, logo a seguir, o uso do verbo lusi) é no mínimo intrigante, e deve nos levar a suspeitar desse menosprezo tão cabal que alguns críticos enxergaram na atitude de Virgílio para consigo mesmo. A sutileza do poeta é brilhante, criando um oxímoro: "florescendo no anonimato".

A presente tese defende que as imitações poéticas, sobretudo as realizadas no Renascimento, fazem interpretações de seus modelos clássicos que, levadas em conta, lançam novas luzes sobre os autores antigos. Mais do que isso, a recepção dos clássicos, na Renascença, não é passiva, e o diálogo intertextual criado no período deve ser examinado e retomado não apenas com o propósito de compreender os autores neolatinos (os imitadores), mas também na tarefa de revisitar, reinterpretar e questionar os autores da Antigüidade (os imitados). A análise da dinâmica de apropriação textual na literatura deve prezar seriamente o movimento de dupla direção que se instala criado pelas alusões, e deve abordá-lo para elucidar tanto o texto derivado quanto o original.

Nesse sentido, a alusão de Gouveia, pelo próprio valor que atribui à expressão originalmente virgiliana, no novo contexto, leva a uma interferência no texto antigo e a um questionamento da compreensão tradicional do sintagma "ignobilis oti". Portanto, sem que seja preciso nos desfazermos do sentido geral da passagem como um todo, que busca 
enaltecer César e colocar Virgílio como um súdito agradecido, que assina a obra, podemos aceitar ou, pelo menos, levar em consideração a visão de Gouveia, que deve ter percebido a manobra de Virgílio, a ponto de repeti-la de modo especialmente apropriado. A partir daí, somos levados a perceber a contaminação de ignobilis pelo seu antecedente florentem, e relativizar o peso depreciativo desse adjetivo, encarecendo o jogo semântico criado por Virgílio e constatando que, afinal, o ócio criativo não sai tão rebaixado assim da passagem. Com efeito, os dois poetas, seja na expressão sutil e refinada de Virgílio, seja na agudeza e na capacidade de alusão de Gouveia, indicaram o espaço para as aspirações de glória da literatura. Ou seja, assim como Gouveia fala de Francisco I, também seria extremamente elogioso, da parte de Virgílio, afirmar que Augusto concedeu aos escritores um "ócio inédito", e que é graças a essa condição, em meio a esse ócio, que o poeta tem possibilidades de compor uma obra que lhe proporcione a glória.

Passemos agora a um comentário mais curto, acerca do verso 47 desta primeira carta:

Vt uideo, ut pereo: subitoque accensa fauilla

O primeiro hemistíquio do verso, antes da cesura pentemímere, tem como fonte o verso VIII, 41, das Bucólicas de Virgílio:

Vt uidi, ut perii, ut me malus abstulit error!

Nesse trecho da écloga, Dámon declara seu amor por Nisa, explicando sua súbita paixão. Como se vê, a alusão intencional é inteiramente pertinente, colaborando para amplificar a manifestação do amor por parte de Gouveia.

O mesmo expediente de aludir a um trecho cujo sentido, no texto original, acaba por se derramar sobre os versos de Gouveia, intensificando seu enunciado e revestindo-os de significações adicionais, pode ser encontrado um pouco adiante, na mesma carta, no verso 64:

Nec fuit ingenio fama sinistra meo

Este verso de Gouveia foi modelado sobre o seguinte verso de Ovídio (Tristia, IV, 10, 126): 
Non fuit ingenio fama maligna meo

A imitação tem uma nítida intencionalidade, pois usou como fonte o mesmo poema dez do livro quatro dos Tristia, de teor autobiográfico, a que Gouveia aludira no verso 17 desta carta, conforme comentamos anteriormente. Ainda por cima, ele imitou um verso em que o poeta sulmonense (ou melhor, sua persona no poema) faz referência à sua própria produção literária. Assim, Gouveia desejou reforçar, mais uma vez, sua identidade com Ovídio, mencionando, desta vez, a boa fama resultante de sua própria produção poética nos mesmos termos que fez o autor clássico.

Examinemos agora o dístico formado pelos versos 79 e 80:

Hem quid ego admisi? quae non ego numina demens,

Quos ego non colui demeruique Deos?

Zeeb percebeu, com propriedade, a semelhança entre a construção gouveiana e aquela do verso 132 do Epicedion Drusi, atribuído a Ovídio; faltou-lhe, porém, percorrer com mais atenção toda essa obra pseudo-ovidiana, pois teria então concluído que está justamente nela a fonte dos dois versos de Gouveia. Com efeito, vejamos os versos 131 e 132 dessa consolatio:

Nam quid ego admisi? quae non ego numina cultu, Quos ego non potui demeruisse deos?

As alterações feitas pelo humanista português servem para ajeitar, com habilidade, o material clássico ao novo contexto; ressalte-se a genialidade com que ele encaixa a palavra demens, usada anteriormente no verso 50 de sua carta poética, para estabelecer a coesão entre o material emprestado e sua própria obra: por um lado, fazendo questão de manter o conteúdo semântico da fonte, transforma o substantivo cultu no verbo colui; por outro, inserindo um termo que aparecera antes, cria uma espécie de gancho que prende e arrasta para dentro de sua obra o fraseado de Ovídio, de tal modo que um leitor que identifique a alusão não deixe de sentir o conjunto como plenamente gouveiano. O sentido também se adapta perfeitamente, pois, na carta, Gouveia lamenta sua separação da mulher amada e, indignado, culpa os deuses, 
num movimento análogo ao de Lívia, no epicédio, que da mesma forma lamenta a morte do filho e, dizendo-se inocente, atribui a culpa aos deuses.

Lembrando o propósito demonstrado por Gouveia de ser um "alter Ouidius", não deixa de ser, este trecho, mais um perfeito exemplar da apropriação que o poeta luso faz da obra de Ovídio, e da aproximação entre ambos, na tentativa de identificação autoral.

Passando agora à segunda carta, encontramos mais uma influência de Ovídio logo na concepção do verso 4 :

Res est plena leuis credulitatis amor.

Há aqui um cruzamento de dois versos extraídos das Heroides: o primeiro é o verso I, 12; e o segundo é o verso VI, 21:

Res est solliciti plena timoris amor. (Heroides, I, 12)

Credula res amor est; utinam temeraria dicar (Heroides, VI, 21)

Em relação ao sentido, há uma nítida correspondência semântica entre a formulação de Ovídio, no verso VI, 21 (Credula res amor est), e a de Gouveia, no verso 4 (Res est plena credulitatis amor), especialmente se aceitarmos a identidade entre "res credula" (Ovídio) e "res plena credulitatis" (Gouveia), ainda que a expressão do poeta português seja mais enfática, uma amplificação da frase clássica. Vemos, ademais, que o único acréscimo feito por Gouveia é a qualificação leuis, admissível no novo contexto e subentendida no texto original. Dessa forma, o poeta preenche a voz de Catherine com a reverberação da fala de Hipsipile, que lamenta a partida de Jasão: une-as a revolta indignada diante do abandono, e a descrença infeliz na palavra do homem amado.

Se o sentido remete sobretudo ao verso VI, 21, analisado acima, a construção do verso parece ser igualmente tributária (ou, talvez, com ainda maior peso) do verso I, 12, seja no número e distribuição das palavras, seja na função de cada palavra, num evidente paralelismo.

Finalmente, cabe observar que Ovídio fez, obviamente, uma auto-alusão, em que o segundo verso citado aponta para o primeiro, não apenas pela semelhança do enunciado (uma 
definição do amor), mas pelo adjetivo "temeraria", cujo som retoma paranomasticamente o substantivo "timoris". Dessa forma, ao compor a carta VI, de Hipsipile a Jasão, Ovídio recuperou o início da carta de Penélope a Ulisses, para marcar a proximidade de situação e de sentimentos de duas mulheres que vêem o homem amado afastado por uma viagem marítima.

É de crer que Gouveia, ao detectar as alusões intratextuais num Ovídio imitador de si mesmo, tenha se sentido respaldado a adotar o mesmo tipo de procedimento poético, e, a partir daí, tenha tecido seus múltiplos diálogos intertextuais. Aliás, numa amostra de sua erudição e de seu rigor detalhista de composição, é notável que Gouveia tenha uma predileção toda especial de imitar trechos que já haviam sido, no passado clássico, imitados ou autoimitados.

Outro bom exemplo de intensificação do sentido em Gouveia ocorre no trecho final da segunda parte desta segunda carta, em que Catherine enumera, em forma de catálogo, um conjunto de maldições que deseja que aconteçam a Gouveia, numa imitação literária de um ritual tradicional romano, de cunho religioso, denominado deuotio. Depois de praguejar por vinte e quatro versos, a personagem Catherine invoca o apoio dos deuses, para que tais males se convertam em realidade e prejudiquem Antônio. Na finalização do trecho, o poeta português compôs o seguinte hexâmetro (verso 37):

Di maris et terrae, Di qui Iouis astra tenetis, ${ }^{76}$

É bem verdade que esse verso se baseia em fórmulas tradicionais de invocação dos deuses, de origem ritualística e popular, e presentes em vários outros textos da literatura latina, de que serve como prova o verso 528, do canto III, da Eneida, de Virgílio, que apresenta o mesmo hemistíquio inicial, antes da cesura pentemímere:

Di maris et terrae, tempestatumque potentes ${ }^{77}$

É com esse verso que Anquises inicia sua invocação aos deuses, pedindo proteção e favorecimento na viagem dos troianos pelo litoral da Sić́lia. A semelhança entre o verso de

\footnotetext{
76 Tradução: Deuses do mar e da terra, Deuses que controlais os astros de Júpiter.

${ }^{77}$ Tradução: Deuses que governais sobre o mar e a terra, e sobre as tempestades.
} 
Gouveia e o de Virgílio se acentua pelo fato de que, após a cesura, ambos se referem aos deuses celestes. Tal fato poderia levar-nos a supor que Virgílio foi a fonte dessa passagem. No entanto, ainda que tal imitação não possa ser descartada - e é até muito provável que Gouveia tivesse conhecimento desse verso da Eneida, um de seus principais constituintes de repertório - a fonte primária de Gouveia é outra: trata-se de uma retomada e condensação dos versos 67 e 68 do poema Íbis (ou Contra Íbis), atribuído a Ovídio:

Di maris et terrae, quique his meliora tenetis inter diuersos cum Ioue regna polos, ${ }^{78}$

Ora, nessa hipótese, o poema imitado é, justamente, um catálogo de maledicências dirigidas por Ovídio contra um suposto adversário pessoal que o teria prejudicado, e ao qual Ovídio atribui a alcunha de Íbis. Dada a semelhança de contextos, a proposta é altamente plausível, e vem reforçada tanto pelo uso do mesmo verbo "tenetis" em posição final, quanto pela referência a Júpiter (Iouis/Ioue). Mais duas reelaborações de Gouveia podem ser listadas: o pronome relativo "qui”, no verso 67 de Ovídio, substitui a palavra "Di", ao passo que Gouveia, sem abrir mão do pronome, desfaz a referência anafórica de Ovídio e usa a palavra "Di” exatamente na mesma posição do pronome em Ovídio; e, finalmente, a métrica de Gouveia é igual à de Ovídio, com três pés dactílicos $\left(1^{\circ}, 4^{\circ}\right.$ e $\left.5^{\circ}\right)$ no hexâmetro, diferente do verso mais solene e arrastado de Virgílio, que usa um espondeu no quarto pé. Portanto, o trecho está calcado no modelo fornecido pelo poemeto de Ovídio. Assim, pelo diálogo intertextual, Gouveia transfere para o eu-lírico da carta toda a carga de revolta e ira presente no Íbis. O leitor tem diante de si o efeito de ampliação das maledicências, e acaba por compreender que o catálogo da obra de Gouveia é apenas um resumo dos mais de quatrocentos versos do Íbis. A virulência do poema clássico, funcionando como um pano de fundo ou subtexto, amplifica o ataque de Catherine e a sensação do leitor.

Ainda assim, não deixa de ser notável o fato de que o verso citado por Gouveia já representava, por sua vez, uma alusão de Ovídio à obra de Virgílio, com o detalhe de que a fórmula solene e de bom presságio, presente na Eneida, foi não apenas apropriada, mas

${ }^{78}$ Tradução: Deuses do mar e da terra, e vós que, junto com Júpiter, controlais reinos melhores do que estes, entre os pólos opostos. 
invertida por Ovídio, que usa o mesmo hemistíquio para fazer, no Íbis, uma furiosa e sinistra imprecação.

Uma vez que nos detivemos mais prolongadamente no exame das fontes do verso 37 , cabe agora observar que, no trecho referido, que compõe a segunda parte da segunda carta poética, há vários outros versos forjados sobre o material ovidiano. Embora não se vá proceder a um exame detalhado dessas alusões, optamos por mencioná-las a seguir, expostas lado a lado, sendo possível comparar a imitação e a fonte:

\section{Exemplo 1:}

Deneget aequor iter, tellus ignota fauorem: (Gouveia, Ep. II, v. 26)

Terra tibi fruges, amnis tibi deneget undas, (Ovídio, Íbis, v. 107)

Deneget afflatus ventus et aura suos. (Ovídio, Íbis, v. 108)

Nec tibi det tellus nec tibi pontus iter. (Ovídio, Íbis, v. 112)

\section{Exemplo 2:}

Sis miser, et soli mihi sis miserabilis ipse: (Gouveia, Ep. II, v. 31)

Sisque miser semper, nec sis miserabilis ulli: (Ovídio, Íbis, v. 117)

\section{Exemplo 3:}

Imperiuratae quique praeestis aquae, (Gouveia, Ep. II, v. 38)

Imperiuratae laberis amnis aquae, (Ovídio, Íbis, v. 78)

Exemplo 4:

Annuite, et uotis omnes subscribite nostris: (Gouveia, Ep. II, v. 39)

Annuite optatis omnes ex ordine nostris, (Ovídio, Íbis, v. 87)

\section{Exemplo 5:}

Expleuit partes iustior ira suas. (Gouveia, Ep. II, v. 40) 
Et peragent partes ira dolorque suas. (Ovídio, Íbis, v. 86)

Para encerrar a análise de alusões da segunda carta, examinemos o verso 70:

Flagret, et occultum pectore uulnus alat

Este verso é um dos mais eloqüentes exemplos da capacidade de alusão, bem como da erudição de Gouveia, a serviço do refinamento poético e da amplitude de construção de sentidos.

Com efeito, poderíamos pensar, num primeiro momento, que Gouveia, como fonte na composição de seu verso, serviu-se unicamente do seguinte pentâmetro das Heróides, em que Fedra se dirige a Hipólito, revelando-lhe toda a força de seu amor secreto:

Ovídio, Heroides, IV, 19-20:

uenit amor grauius, quo serius - urimur intus;

urimur, et caecum pectora uulnus habent.

Mas parece possível que Gouveia tenha percebido que esse mesmo verso de Ovídio é, por sua vez, uma alusão a uma passagem da Eneida, em que Dido se refere ao seu amor tormentoso por Enéias:

Virgílio, Eneida, IV, 1-2:

At regina graui iamdudum saucia cura uulnus alit uenis et caeco carpitur igni.

A alusão, discreta, mas evidenciada pela repetição do vocabulário (grauis; uulnus; caecus), pela curiosa paronomásia uenis-uenit e pela remissão semântica de urimur a igni, transmite a Fedra a conhecida pungência do amor que Dido sentira.

Ao usar o verbo alat em seu verso, Gouveia demonstra ter reconhecido a antiga alusão e, mais do que isso, compõe seu pentâmetro a partir de um minucioso cruzamento do verso de Ovídio (fonte principal) com o de Virgílio (fonte secundária). Dessa forma, ele próprio 
adentra a rede de intertextualidades e inscreve-se na memória poética clássica revigorada e inesperadamente aumentada. Assim, o repertório clássico, em lugar de cristalizado no testemunho do passado, encontra-se subitamente remodelado, com novos limites.

Em relação ao efeito que Gouveia cria para seu texto, a genialidade não é menor: sua heroína, Catherine, por conta da alusão, incorpora, num único passo, as personae de Fedra e Dido: isso não apenas engrandece de sentido e valor a figura de Catherine, identificada com duas personagens clássicas, como dá uma nova profundidade de significado ao sentimento expresso por Catherine, que passa a revestir as mesmas dores e violências dos amores lancinantes e secretos de Fedra e Dido.

O tour de force de Gouveia é ainda mais estimável se observarmos que se fez com o uso, em especial, de um vocábulo que é particularmente vinculado a Ovídio e à Eneida virgiliana: trata-se da palavra uulnus. Com efeito, esse termo é marcadamente ovidiano, e, secundariamente, próprio da "Eneida". Assim, se fizermos um rápido levantamento do emprego dessa palavra entre os autores canônicos mais provavelmente conhecidos por Gouveia (Catulo, Horácio, Propércio, Tibulo, Virgílio, Ovídio, Marcial e os comediógrafos Plauto e Terêncio), veremos que, na forma uulnus (nominativo ou acusativo singular), a palavra nunca foi empregada por Catulo, Horácio, Tibulo ou pelos cômicos; de 73 empregos, 52 são em Ovídio (71\%), 16 na "Eneida" (21\%), 2 em Propércio, 2 em Marcial e 1 na Appendix Vergiliana (Catalepton). Se investigarmos as formas declinadas, as proporções se mantêm semelhantes: cerca de 62\% dos registros em Ovídio, $21 \%$ na Eneida e $4 \%$ em Propércio; em números absolutos, de 261 empregos, 162 são em Ovídio, 55 na Eneida e 11 em Propércio.

Assim, o mero uso do termo já remete fortemente para Ovídio e para a "Eneida" de Virgílio. E também disso parece que Gouveia estava consciente, pois o termo uulnus, do verso 70, foi preparado pelo uso repetido, em poliptoto, de uulnus e uulneris, em anadiplose, nos versos 61 e 62 da carta. Assim, Gouveia sinalizou previamente o cruzamento alusivo que viria a executar alguns versos adiante.

Quanto à terceira carta, selecionamos um único trecho, especialmente sintomático do trabalho poético de Antônio de Gouveia. Trata-se dos dísticos formados pelo versos 83 a 86: 
Dicitur, erepta Briseide, maestus Achilles

Bistonia lacrimas continuisse lyra.

Cum traheret silvas deserti ad Strymonis undas

Orpheus, Eurydice rapta bis uxor erat.

Esses dois dísticos são o resultado da conjugação de duas alusões simultâneas. A primeira remete aos versos IV, 504 e 508, das Geórgicas, de Virgílio:

Quid faceret? quo se rapta bis coniuge ferret?

$(\ldots)$

Rupe sub aeria deserti ad Strymonis undam

A segunda alusão, muito mais evidente, se apóia nos versos dos Tristia, IV, 1, 15-18, a seguir:

fertur et abducta Lyrneside tristis Achilles

Haemonia curas attenuasse lyra.

cum traheret silvas Orpheus et dura canendo

saxa, bis amissa coniuge maestus erat.

O tema da passagem de Ovídio é a consolação do sofrimento por meio da poesia. Foi exatamente por tratar desse assunto que Antônio de Gouveia, ao discorrer sobre o assunto, usou o material poético dos Tristes como base de sua composição. Pela alusão, Gouveia faz sua adesão ao pensamento do poeta clássico e, como sempre, decalca sua persona na persona de Ovídio, criando uma identidade baseada nos elementos afins: dois poetas distantes de sua terra natal, que cantam para afastar o sofrimento. Mas o mais curioso é que, aproveitando-se do fato de que Ovídio, no segundo dístico da passagem, fazia menção ao mito de Orfeu, o humanista português foi buscar em Virgílio, nas Geórgicas, uma segunda narrativa do mesmo mito, e efetuou uma colagem dos dois trechos poéticos. Mais uma vez, Gouveia revela grande erudição, pois, de um lado, moldou seu próprio texto sobre duas versões diferentes, dos dois autores que ele utiliza como seus maiores modelos; e, de outro lado, mostrou mais uma vez que foi capaz de reconhecer a alusão de Ovídio a Virgílio. Assim, ao fazer a colagem dos dois, teceu mais um elemento numa teia intertextual já anteriormente tramada. 
Finalmente, na quarta carta, há outras comparações produtivas que podem ser feitas. Comecemos com o trecho abrangido pelos versos 27-30 e 35-37, que permite múltiplas considerações:

Non mihi laesus Amor, Matris non spreta potestas,

Non sum Tydīdae criminis author ego.

Non data deserui duce signa Cupidine: semper

Semper militiae dux fuit ille meae.

$(\ldots)$

Parce infelices sceleris damnare Cupido

Vatibus infensum non decet esse tuis.

Dic mihi quid feci, nisi quod bene semper amaui?

Compare-se com alguns versos do início da obra Remedia Amoris, de Ovídio (vv. 3 a 5 e 7):

Parce tuum uatem sceleris damnare Cupido

Tradita qui toties te duce signa tuli.

Non ego Tydīdes (...)

$(\ldots)$

ego semper amaui.

A intertextualidade mais evidente é a retomada do verso 3 de Ovídio, que dá a base do verso 35 de Gouveia, com a substituição de "tuum uatem" por “infelices". Mas a expressão "tuum uatem" não se perde em Gouveia, antes se transforma no "uatibus tuis" do verso seguinte (v. 36), expressão que, no plural, abarca, se não todos os elegíacos, pelo menos Gouveia e seu inspirador Ovídio. Gouveia se equipara a Ovídio, na medida em que também é prejudicado por Cupido. Note-se que a ampliação de sentido se faz acompanhar pela expansão, ao longo do verso, do sintagma "uatibus tuis", com a separação entre o substantivo 
e o pronome "tuis", que ocupa a última posição do verso. O adjetivo "infelices", por sua vez, projeta-se sobre a expressão, qualificando-a.

Há, ainda, muitas outras reelaborações, como Tydides > Tydidae; tradita signa tuli > data deserui signa; te duce > duce Cupidine; ego semper amaui > bene semper amaui. Gouveia, com esses mecanismos, amplia o texto original, reforçando-o ou especificando-o através de novos detalhes. Além disso, ele faz suas próprias contribuições ao texto literário, utilizando recursos retóricos clássicos, como a anáfora (Non) e a anadiplose (semper). Também emprega o vocabulário e o ideário da elegia erótica romana na composição do verso 30. No prólogo dos Remedia Amoris, Ovídio reafirma sua adesão ao amor e à poesia amorosa. Gouveia se apropria dos versos desse prólogo para amplificar suas juras de amor e fidelidade à mulher amada, bem como para confirmar sua condição de poeta elegíaco.

Enfim, todos esses procedimentos poéticos acabam por inserir o humanista do século XVI nos mesmos parâmetros da poesia de composição genérica e alusiva da época clássica latina. E, igualmente, acabam por revelar seu enorme valor e interesse.

Próximo do final da obra, Gouveia tenta convencer Catherine a permitir-lhe ser o cantor de suas virtudes, apelando para a idéia de memória, que se opõe à de efemeridade. Segundo ele, seus versos preservariam a memória dela para a posteridade. Nesse passo, ele lapida o seguinte verso, número 70, da quarta carta:

Crede mihi, fugiunt carmina sola diem.

Nota-se uma alusão ao seguinte verso ovidiano (Amores, III, 9, 28):

Defugiunt auidos carmina sola rogos

Trata-se da elegia em que Ovídio chora a morte de Tibulo, mas se consola com a perspectiva de que a obra do poeta ficará preservada e sobreviverá à morte do corpo. $\mathrm{Na}$ composição de seu verso, Gouveia recorre à matriz de Ovídio, mas alcança uma formulação mais concisa e pungente, ao retirar o prefixo do verbo e ao substituir a expressão "auidos rogos" pelo simples "diem", ao mesmo tempo tão breve e tão amplo de significados na poesia clássica. Constata-se, assim, como o imitador é capaz de aperfeiçoar o modelo, e, mesclando influências e fontes, chegar a uma sententia ainda mais intensa do que a anterior. 
Mas a alusão observável nessa passagem não deve ser analisada de modo tão restrito. Com efeito, o uso da imagem da pira funerária ("rogus"), como tropo da morte, que devora as coisas transitórias e poupa as perenes, é mais complexo, se observarmos o conjunto da obra de Ovídio - e devemos sempre levar em consideração que o contato de Gouveia foi com esse conjunto, num diálogo com o todo, ainda que a citação se faça mais diretamente sobre um verso ou trecho determinado.

De fato, Ovídio parece ter revisto seu próprio verso, ao escrever, já no exílio, o seguinte pentâmetro (Tristia, III, 3, 60):

Effugiatque auidos pars mihi nulla rogos

Se antes Ovídio afirmava o poder da poesia, capaz de sobreviver muito além de sua época, agora parecemos escutar um poeta desencantado que, diante da amargura do exílio, ansioso pela morte redentora (conforme suas palavras em Tristes, III, 2), exprime o desejo, num subjuntivo volitivo, de que "nenhuma parte de mim escape da ávida pira". Segundo Colin Burrow ${ }^{79}$, todo o trecho em que se insere este verso é uma revisão de doutrinas pitagóricas expostas no livro XV das Metamorfoses, motivada pela consciência do autor diante das circunstâncias históricas e da efemeridade da vida. Assim, de forma pessimista, o poeta passa a considerar a imortalidade uma "fonte de horror", e o esquecimento, "uma libertação desejável”.

Parece, no entanto, que o poeta, no exílio, não se tornou tão pessimista assim, e que soube conservar uma boa dose da ironia que lhe é peculiar. De fato, é inegável que o verso dos Tristes retoma o dos Amores, e que, por isso, ao declarar que deseja que nada sobreviva à sua morte, Ovídio está se referindo aos poemas compostos por ele. Mas será que o poeta, neste momento, quer mesmo morrer? Quer mesmo ser esquecido? Quer mesmo que pars nulla sobreviva? Se observarmos vários outros poemas, em que Ovídio reelabora o mesmo verso e a mesma imagem do "fogo devorador", creio que não.

Com efeito, as duas passagens a seguir, carregadas de elementos alusivos, revelam a crença do poeta no fato de que as grandes obras, e o prestígio decorrente delas, permanecem além da vida:

79 Burrow, "Re-embodying Ovid: Renaissance afterlives", in The Cambridge Companion to Ovid, pp.301-302. 
Pônticas, III, 2, 32:

Effugiunt structos nomen honorque rogos

Epicedion Drusi (Consolatio ad Liuiam), 265-266:

Facta ducis uiuent operosaque gloria rerum:

Haec manet, haec auidos effugit una rogos.

Aliás, ele chega mesmo a incentivar sua filha a se tornar uma escritora capaz de compor versos que escapem do tempo, numa recomendação que vamos encontrar no mesmo livro terceiro dos Tristia (III, 7, 54):

Effuge uenturos, qua potes, usque rogos!

Portanto, o "fogo fatal" é incapaz de destruir a obra poética de valor, que fica preservada na memória dos homens. No entanto, o "fogo" não poupa as obras vis e secundárias, que perecem diante das chamas. Não por acaso, o "fogo" assume uma função "purgatória", como Ovídio explica ao falar de "emendaturis ignibus" (em Tristia, IV, 10, 62), faceta que também se nota em Tristia, IV, 1, 102:

Misit in arsuros carmina nostra focos

Nessas passagens todas, há uma mesma idéia central: poucas são as grandes obras, mas elas sobrevivem na memória seletiva; muitos poemas, no entanto, perecem, e o próprio Ovídio lançou ao fogo, antes de publicar, muito do que escreveu; a qualidade do texto é que estabelece o critério da permanência. Se o poeta pensa assim, e se tantas vezes indica que essa é, de fato, sua conclusão, começa a ser conveniente considerar como uma grande ironia aquela passagem em que ele clama pela extinção de sua obra. Mas o argumento definitivo encontrase, em minha opinião, na própria elegia em que ele expressou esse desejo. Com efeito, catorze versos após o referido verso, ele cunha seu próprio epitáfio, no qual deixa claro que deseja ser lembrado como "Naso Poeta", "tenerorum lusor amorum". Ora, trata-se da mesma expressão 
do poema 10, do volume seguinte dos Tristia, numa flagrante auto-imitação. Na rede intertextual, a última elegia do quarto livro dos Tristes (a mesma em que Ovídio expressa seu desejo de ser lembrado) retoma e arremata a elegia anterior, fechando o círculo e desmentindo o anseio de morte e esquecimento antes expresso, e mais bem compreendido, por sua vez, pela chave da ironia: o desejo do poeta, ao contrário, parece ser o da plena compreensão por parte dos leitores. Que sirvam de confirmação a essa interpretação alguns versos do final da mesma elegia III, 3, dos Tristes: o citado epitáfio é uma recordação menor do poeta, diante de seus livros, "maiora monimenta", que darão ao seu autor "nomen et tempora longa".

Mas voltemos a Gouveia. É, realmente, admirável, que o poeta português, ao embarcar na discussão tão cara a Ovídio, sobre a efemeridade e perenidade, forje um verso alusivo ao poeta latino, verso em que declara, nos moldes clássicos, a sobrevivência da poesia, e, ao citar Ovídio, isto é, ao presentificar Ovídio, consiga, no nível material da frase, na elocução, isto é, em ato, a própria preservação da memória potencialmente pretendida pelo poeta clássico. Em outras palavras, é admirável que Gouveia, ao declarar que a poesia não morre, o faça citando um verso de mil e quinhentos anos antes.

Outro verso notável de Gouveia é o de número 86:

[umbras]

Quas dirus caeca tabe perēdit Amor. ${ }^{80}$

Compare-se com o verso VI, 442, da Eneida de Virgílio:

hic quos durus amor crudeli tabe perēdit ${ }^{81}$

Como se vê, Gouveia reelaborou o verso virgiliano, mantendo uma série de correspondências entre seus elementos: quos > quas; durus amor > dirus Amor; crudeli tabe > caeca tabe. Nota-se, sobretudo, a alteração na ordem das palavras: a disposição lado a lado

\footnotetext{
${ }^{80}$ Tradução: [almas] / que o implacável Amor devastou com uma paixão cega.

${ }^{81}$ Tradução: aqui, aqueles que o duro amor devastou com uma paixão cruel.
} 
dos pares sintagmáticos "durus amor" / "crudeli tabe” dá lugar a uma disposição intercalada, em que "dirus Amor" abraça e contém “caeca trabe". Por outro lado, o poeta português não alterou a disposição "adjetivo + substantivo" de cada par.

Mais do que a reelaboração vocabular ou sintática do verso, deve-se notar o efeito de ampliação relacionado ao aspecto semântico da passagem, pois a escolha de Gouveia esteve longe de dar-se ao acaso. De fato, neste momento da carta, Gouveia diz que a recusa de Catherine acabará por levá-lo à morte, fazendo com que ele se una, no mundo dos mortos, às mulheres que morreram de amor, para juntos misturarem suas lágrimas ("lacrimas omnes miscebimus una"). Ora, o verso evocado da epopéia está no canto VI, justamente aquele em que Enéias desce ao mundo dos mortos e, em determinado momento, encontra os "Lugentes campi" ("campos das lamentações"), em que estão as almas de Dido e de outras mulheres apaixonadas. Portanto, o sofrimento amoroso apresentado na Eneida se projeta sobre a carta de Gouveia, e a aflição daquelas que morreram por amor, na projeção intertextual, realça a angústia do poeta. Nota-se, novamente, o enriquecimento produzido pelo diálogo entre os textos e, ademais, o trânsito entre os diferentes textos da Antigüidade na composição da obra renascentista.

Foi dito, logo de início, que as cartas, em dísticos elegíacos, são claramente modeladas nas Heróides, e que Gouveia explicita isso no posfácio dirigido a Jacques de Beaune. Mas também nos trechos finais desta quarta carta Gouveia faz uma alusão a essa obra de Ovídio, quando compara sua amada Catherine a todas as heroínas, nos versos 97 e 98, de forma a assinalar, dentro do poema, a fonte dos versos:

\section{Heroidas omnes,}

Tu quibus es maior sanguine, laude minor. ${ }^{82}$

Se pensarmos na assinatura (ou sphragis) que os poetas clássicos costumavam apor ao texto, constataremos que Gouveia, de modo análogo, levou ao poema a assinatura do "modelo poético", identificando, dentro da composição, a fonte da obra. E, ao fazê-lo, cuidou de manter a elevada qualidade literária, em que saltam aos olhos recursos como o quiasmo na

${ }^{82}$ Tradução: todas as heróides, / em relação às quais tu és maior em sangue, em glória menor. N.B: "sangue" indica desde nobreza, origem ou linhagem, até valor ou energia. 
antítese (maior sanguine / laude minor) e o emprego do pronome pessoal, enfático, em primeiro lugar no verso 98, bem de acordo com os moldes clássicos.

Examinamos, acima, muitos trechos que, pelo caráter alusivo, permitem uma melhor compreensão dos princípios artísticos de Gouveia e de sua inserção na teia literária clássica. Porém, pelo acúmulo de exemplos, podemos ter dado a falsa impressão de que Gouveia apenas reelabora ou reorganiza material alheio, sendo incapaz de compor versos autônomos.

Para contrapor essa impressão errônea, selecionamos um trecho de sua lavra, muito bem versificado, que se encontra na terceira carta, entre os versos 41 e 50, citados a seguir:

Sola tamen fortuna deest, non altior omni

Mens casu et duris durior usque malis.

Non exculta deest studiis melioribus aetas,

Non deest ingenio fama benigna meo.

Non deest nobilitas ab auis proauisque relicta,

Successor cuius ordine factus ego.

Non deest (quo recreor) uiridisque ualensque iuuenta,

Non spes ad magnos difficilesque gradus.

Sola mihi fortuna deest, Catharina: sed illa

Non uno semper statque manetque loco.

O procedimento de composição básico do trecho é a repetição acumulativa, e a palavra-chave da passagem é o verbo "deest", repetido seis vezes nos dez versos; todo o excerto se organiza sobre esse termo, associado, a partir do verso 43, ao advérbio "non". Nos versos 44, 45 e 47, a locução “non deest” vem repetida em anáfora. Já sem o verbo, o advérbio é repetido mais duas vezes, em anáfora, nos versos 48 e 50, ao passo que "deest", sem o advérbio, é repetido no verso 49, que, aliás, reitera o hemistíquio inicial do verso 41 , que abre o trecho. Com isso, Gouveia consegue fazer um trecho em que há, ao mesmo tempo, um movimento circular e um movimento linear progressivo. De fato, ao repetir a frase "sola (...) fortuna deest", ele estabelece o tema do trecho (a pobreza do poeta) e o movimento circular, em que o verso inicial é retomado no penúltimo, fechando o ciclo; ao mesmo tempo, 
ao apresentar a palavra deest, primeiramente, sozinha, depois acompanhada de non (mas não ladeadas, em "non exculta deest"), depois ladeadas, até "non" se desprender de "deest" (primeiramente, mantendo uma proximidade pela sonoridade de "non spes") e terminar independente (abrindo o último verso), Gouveia estabelece uma linha evolutiva para o trecho, em que "deest" e "non" começam de uma maneira e terminam de outra: "deest" aparece sozinha, atrai "non", que, no final, acaba por ganhar vida própria. Os dois movimentos, somados, dão conta da amplificação que prevalece no excerto: são mencionadas muitas qualidades de Gouveia, mas repete-se, como um refrão, a sentença de que lhe faltam recursos. Porém, a sentença, embora repetida, é suavizada pelo final esperançoso, de sabor estóico: "illa non uno semper statque manetque loco".

As repetições (seis vezes "deest", seis vezes "non") são o principal recurso para intensificar o dilema entre as muitas virtudes do humanista (realçadas por acumulação) e a sua má sorte na vida. Mas outros recursos literários são utilizados na composição do trecho. Notese, por exemplo, o poliptoto "duris durior", do verso 42, intensificador que enaltece a capacidade espiritual de Gouveia, ou o poliptoto "meo / ego", dos pronomes de primeira pessoa, para realçar o foco na subjetividade do trecho, como já vimos, por exemplo, na abordagem dos epigramas; observe-se, ademais, a posição enfática dos pronomes, no fim do verso, e seu paralelismo com a palavra "malis", que encerra o verso 42, provocando uma aproximação entre a persona do eu-lírico e os males que o afligem.

Por fim, devemos perceber dois reaproveitamentos de material poético. O primeiro, no verso 44, é uma referência intratextual ao verso 64, da carta I, o qual, por sua vez, já era uma alusão ao verso IV, 10, 126, dos Tristia, de Ovídio:

Non deest ingenio fama benigna meo. (Gouveia, Ep. III, 44)

Nec fuit ingenio fama sinistra meo. (Gouveia, Ep. I, 64)

Non fuit ingenio fama maligna meo (Ovídio, Tristia, IV, 10, 126):

Dessa maneira, Gouveia reforça o laço coesivo entre as cartas e, secundariamente, fortalece a alusão a Ovídio. Cabe reparar que, na reutilização do verso, Gouveia faz uma dupla alteração de valor antitético, trocando "fuit" por "deest" e "sinistra" (ou "maligna") por "benigna": procedendo tal qual num litotes, o poeta luso forja, pela dupla inversão, o fortalecimento da idéia contida no verso. 
O segundo reaproveitamento se dá no verso 45, que reutiliza, com alterações, o verso I, 36, 7 de um epigrama, justamente dedicado a Catherine, que foi excluído da publicação de 1540. Façamos a comparação:

Non deest nobilitas ab auis proauisque relicta, (Gouveia, Ep. III, 45)

$\mathrm{Si}$, quae est nobilitas ab auis proauisque relicta, (Gouveia, Epigr. I, 36, 7)

O verso do epigrama dedicado a Catherine fazia o louvor dos antepassados da mulher amada, atribuindo a ela a nobreza proveniente da família. É a mesma intenção que se registra no verso da carta, agora em relação ao próprio Gouveia, que, em suas palavras, é de origem nobre. É difícil concluirmos qual foi a intenção do poeta com essa alusão, se é que podemos chamar assim, neste caso. Seria uma forma de estreitar os laços entre as cartas poéticas e os epigramas? Ou de mostrar que os epigramas amorosos a Catherine foram substituídos por longas cartas de amor? Ou seria somente uma forma de aproveitar um belo verso que, de outro modo, ficaria de fora da publicação de 1540? É possível que todos essas três intenções tenham acorrido a Gouveia.

Como dito de início, este capítulo da tese se propunha a estudar os princípios estilísticos por trás da composição literária de Antônio de Gouveia, por meio da análise de sua obra poética em geral e de alguns poemas ou excertos em particular.

Podemos concluir que o humanista português utiliza com talento e arte as ferramentas tradicionais da criação poética, servindo-se do repertório clássico de recursos literários, para produzir versos notáveis, cujo valor é enriquecido pelas referências intertextuais meticulosamente elaboradas por ele. Com efeito, um dos princípios da composição poética de Gouveia que pudemos perceber ao longo do estudo é o do diálogo com suas fontes, num processo dinâmico de reenquadramento do significado original.

Nesse sentido, as alusões de Gouveia tanto podem ser ratificadoras do enunciado original, permitindo uma intensificação do significado anterior, quanto retificadoras, reordenando e até alterando a formulação do autor antigo, como que refundando o texto canônico. De uma forma ou de outra, somos levados a uma releitura da obra clássica que 
serve como fonte, assim como somos levados a ler a obra do poeta renascentista lusitano com um olhar escorado na literatura clássica.

Aliás, a habilidade e o vigor de Gouveia se encontram, em parte, nessa capacidade de revisitar o texto clássico, não para simplesmente acompanhá-lo, num processo fútil de ornamentação do texto ou de exibição da erudição, mas, por vezes, para subvertê-lo, num papel ativo de verdadeira revitalização do patrimônio literário canônico.

Seja promovendo, seja afrontando os textos clássicos, Gouveia aciona o repertório da poesia antiga, tornando efetivos, em pleno século XVI, os preceitos de composição genérica, as normas de versificação, os recursos literários e o cabedal poético acumulado pela tradição, entre outros aspectos da arte poética clássica.

Portanto, a presença clássica está garantida na obra de Antônio de Gouveia, numa profundidade muito maior do que poderia parecer à primeira vista. E, nesse sentido, Gouveia não faz uma colagem superficial ou artificiosa do repertório do passado, mas mergulha profundamente no ideal estético clássico e inculca em si mesmo o próprio modo de composição dos modelos antigos. As alusões e refacções de que o poeta português se serve repousam, com efeito, sobre os mesmos princípios constituintes da poesia latina. 


\section{Capítulo 3}

\section{GRITÉRIOS ESTILÍSTICOS DAS}

\section{REVISÕES}

\section{TEXTUAIS DE ANTÔNIO DE GOUVEIA}

Neste capítulo da tese, procuraremos analisar as alterações ocorridas entre as duas publicações da obra epigramática de Antônio de Gouveia, editada nos anos de 1539 e 1540, a fim de investigar os critérios estilísticos envolvidos nas mudanças.

Trata-se, na verdade, da raríssima oportunidade, em relação a obras antigas, de verificar dois diferentes momentos de um texto, revisado e corrigido pelas mãos do próprio autor. Essa mudança, que abrangeu somente os epigramas, e não as cartas poéticas, permite entrever os mecanismos de composição literária colocados em funcionamento por Gouveia, e podemos acompanhar a evolução de seu projeto artístico, como se tivéssemos acesso a um manuscrito prévio do texto.

De fato, a análise comparativa das edições de 1539 e 1540 permite desvendar, por exemplo, a adoção de diferentes fontes literárias, ou a valorização de diferentes estilos, bem como os critérios que nortearam mudanças lexicais ou alterações no uso de figuras de linguagem.

Essa análise interpretativa se vale do fato de que as transformações são dos mais diferentes graus: há mudança no número total de peças, com uma pequena redução, de 105 a 100 epigramas; para isso acontecer, houve um corte de poemas, e, simultaneamente, a criação de novos, redefinindo o perfil do livro; há modificações gerais, extensivas, e há mudanças pontuais, ou seja, há mudanças no livro como um todo (caso da apresentação dos títulos) e há alterações particulares nos epigramas repetidos.

Uma vez que o número de alterações é grande e elas são, como se acabou de dizer, muito heterogêneas, e uma vez que, ademais, não é a intenção deste trabalho esgotar a análise dessas alterações, mas, antes disso, demonstrar a possibilidade de explorar essa abordagem da 
obra de Antônio de Gouveia, expondo a potencial riqueza de conhecimentos advindos disso e propiciados pela característica quase singular dessa obra entre os autores renascentistas, a opção desta pesquisa foi a de selecionar alguns epigramas ou algumas passagens específicas para ilustrar uma possível interpretação resultante do exame das modificações.

Antes disso, verificaremos de passagem algumas características das mudanças mais gerais. Como foi dito, a edição de 1540 reduziu o número de epigramas a cem, excluindo-se, nessa contagem, o poema introdutório "Libellus Lectori".

Em relação aos subgêneros temáticos em que dividimos os epigramas, no capítulo anterior, podemos notar uma alteração no perfil da obra, a partir da reprodução dos dados já apresentados anteriormente; em 1539, temos 105 epigramas assim divididos:
a) laudatórios: 11;
b) sepulcrais: 9 ;
c) amorosos: 21 ;
d) jocosos: 64;

TOTAL: 105 .

Em 1540, o número passa a 100 epigramas, assim divididos:
a) laudatórios: 16;
b) sepulcrais: 16;
c) amorosos: 13 ;
d) jocosos: 55 ;

TOTAL: 100 .

Esses números levam a que se julgue o livro de 1540 mais organizado, mais corporal, mais bem acabado e mais planejado. Com efeito, o número exato de cem epigramas é simbólico, e remete a antologias publicadas com alguma freqüência no século XVI, em livros que se propunham a trazer os cem melhores epigramas da Europa, ou os duzentos melhores epigramas clássicos, sempre anunciados, em números redondos.

Ao mesmo tempo, Gouveia teve a mestria de manter, com dois artifícios, o mesmo número de poemas da versão anterior, pois, se somarmos o poema introdutório e as quatro cartas poéticas, chegaremos às mesmas 105 composições do volume do ano anterior. 
Se, de um lado, manter o número de epigramas dá ao volume de 1540 uma feição de reedição da mesma obra, de outro lado, a divisão em cem epigramas e quatro cartas acarreta três vantagens: primeiramente, salienta a independência das obras, publicadas com dois números de forte conotação simbólica (100 e 4); em segundo lugar, indica uma intencionalidade e também uma preocupação com a aparência e a organização do livro, e aponta para um cuidado maior no plano da estrutura do livro; em terceiro lugar, permite ao autor exibir seu domínio técnico em dois tipos diferentes de composição, ou seja, epigramas curtos e longas elegias, demonstrando aos colegas da república das letras seu savoir faire, seus dotes literários e sua versatilidade como poeta completo.

Ademais, se juntarmos a isso a mudança no perfil temático dos epigramas, reforçaremos a idéia de que a edição de 1540 é mais contida e solene, especialmente se notarmos que há uma elevação substancial no número de poemas laudatórios e, sobretudo, sepulcrais. Por outro lado, a queda no número de poemas amorosos deve ser analisada à luz da compensação existente pelo fato de o mesmo livro trazer quatro cartas de amor, com 380 versos dedicados à mesma Catherine cujos epigramas deixaram de figurar na edição. Assim, a queda ainda mais substancial e reveladora se dá no número de poemas jocosos, que passa de 64 a 55. Note-se, ademais, que Gouveia retirou da nova versão os poemas mais obscenos ou mais sarcásticos, tais como: I, 7; I, 11; I, 31; I, 35; I, 43; e II, 31; desse modo, confirmamos, mais uma vez, que a edição de 1540 tem um perfil mais discreto e grave do que a de 1539 .

Além da questão temática, há outras mudanças que dizem respeito ao conjunto da obra. Uma mudança de caráter geral é a substituição da fórmula "ad + acusativo" por "dativo", na construção dos títulos dedicatórios dos epigramas. Outro cuidado geral foi o maior cuidado na ortografia das palavras, com algumas correções extensivas, caso da grafia latinizado do sobrenome Gouveia, que passa de "Gouueanus" a "Goueanus" ao longo de todo o livro.

Feita essa abordagem sinóptica, passemos ao exame de transformações textuais específicas. Para isso, decidimos começar pelos textos em prosa que acompanham a publicação da obra poética, em forma de prefácio ou posfácio, pois seu exame também revela alguns critérios estilísticos que comandaram as alterações ocorridas entre as duas versões de redação.

Como dito acima, não pretendemos vasculhar toda a obra do humanista português, motivo pelo qual exemplificaremos as virtudes desse tipo de abordagem no exame restrito dos 
dois primeiros parágrafos da carta que serve de prefácio aos epigramas, endereçada ao amigo Jacques de Beaune.

Para facilitar a compreensão da análise, expõem-se, a seguir, os dois parágrafos a serem submetidos a uma análise comparativa, começando pela versão de 1539 .

1. CVM interim a grauioribus me cogitationibus recolligerem, si quid argute scribi posse uidebam, id epigrammate concludere laborabam: praesertim cum ad scribendum esset animus, esset ea facultas, quam usu quidem litterarum prope nullo partam, et conquisitam, exercitatio potuit aliqua confirmare, amicorumque accederet inani fortasse spe, incensa tamen, ac inflammata exhortatio.

2. Verum cum ad nouos et ueteres scriptores, qui in hoc genere clari ac nobiles extitere, cogitationem paulisper referebam, frangi me animo, debilitarique, nescio quomodo, sentiebam: qui nouitatis illos nomine non displicere, hos antiquitatis gratia probari plurimum intelligerem: quorum altero ad nostrorum laborum commendationem abuti non possem, altero ne uti quidem uellem.

A seguir, a mesma carta, na versão de 1540.

1. SIQVANDO a studiis me grauioribus colligebam, Iacobe Belnaee, quae epigrammate digna uidebantur, epigrammate ut includerem laborabam: erat enim ad scribendum animus, erat ea facultas, quam litterarum usu prope nullo partam, et conquisitam, exercitatio uix aliqua confirmarat, non deerat tua, amicorumque omnium, inani fortasse spe, incensa tamen, atque inflammata cohortatio.

2. Verum, ubi ad nouos, et ueteres scriptores, qui hoc in genere clari, et nobiles extitere, cogitationem paulisper conferebam, debilitabar nescio quomodo, animoque frangebar: qui gratiam nouitati concessam, antiquitati autoritatem esse tributam uiderem.

Primeiramente, interpretaremos alguns casos de mudanças concernentes à escolha vocabular. Selecionamos, no primeiro parágrafo, as seguintes trocas:

1) "Cum interim" por "Siquando": são conjunções de valor semântico equivalente, mas a primeira, usada por Gouveia em 1539, é de emprego muito mais raro (quando usada como locução, com os dois termos nessa ordem), e aparece apenas em Cícero (discursos e 
cartas); a segunda é muito mais freqüente, aparece repetidas vezes em textos de preceptiva retórica (De Oratore, Rhetorica ad Herennium) e em diversos poetas, como Ovídio, Propércio e Virgílio, ou seja, encontra amparo muito maior no cânone literário clássico;

2) "recolligerem" por "colligebam": o verbo usado na edição de 1539 tem sentido mais específico e reforça a idéia de "recuperação de um estado doentio"; o verbo "colligo", por sua vez, além de muito mais comum, suaviza essa mesma idéia, a ponto de neutralizá-la em meio a tantos usos diferenciados; considerando que a atividade a que Gouveia se dedicava, nesses anos, era a de estudante, editor e comentador de textos antigos, isto é, uma atividade própria de humanistas dedicados aos estudos clássicos, caracterizar esse afazer como desgastante ou como uma "doença" de que devemos nos recuperar não parece ser apropriado; daí, ao que parece, a sutil mudança do vocábulo;

3) "concluderem" por "includerem": outra mudança sutil e apropriada, pois o verbo concludo é mais utilizado no contexto da oratória, ao passo que includo, de emprego menos freqüente na literatura clássica, aparece mais vezes relacionado com a poesia, especialmente com a idéia aqui presente de "elaborar uma matéria poética nos limites de determinado gênero", "dar uma forma poética, metrificada, a um determinado assunto"; o novo vocábulo, portanto, está mais adequado ao contexto de Gouveia, que, nesse trecho, se refere à composição de epigramas. Além disso, o termo foi empregado por autores antigos (como Horácio ou Propércio) exatamente nesse sentido, diferentemente de concludo, que, raro nos poetas, aparece freqüentemente em Cícero, no âmbito dos textos em prosa, para se referir ao fecho de um período.

4) "exhortatio" por "cohortatio": o termo cohortatio encontra respaldo muito maior na literatura clássica, não sendo desconhecido de Cícero, um dos grandes referenciais dos autores neolatinos; já o sinônimo exhortatio é raríssimo. É de supor que a preferência dos antigos pesou na troca do vocábulo, que estaria, assim, mais bem escolhido e referendado. Diga-se de passagem, no entanto, que o emprego dos dois substantivos é pouco comum na literatura clássica, em comparação com o emprego mais freqüente dos verbos cognatos, exhortor e cohortor.

No segundo parágrafo, vejamos as seguintes trocas:

1) "Verum cum" por "Verum ubi": a alteração parece ter duas fortes motivações. Em primeiro lugar, evita o uso de cum, excluído do mesmo trecho inicial em que, na versão de 
1539, aparecia por três vezes seguidas. Aparentemente, Gouveia arrependeu-se do uso excessivo da conjunção e trocou as três ocorrências de "cum"; neste terceiro registro, por "ubi”. Em segundo lugar, a locução "uerum ubi” encontra mais respaldo entre os autores clássicos e é usada sempre como abertura de verso, conforme se registra em Horácio (3 vezes), Ovídio (2 vezes), Plauto (2), Terêncio (3) e Virgílio (8 vezes, sendo 4 delas nas Geórgicas). Já a locução “uerum cum” é raríssima: entre os poetas, há um único registro, em Plauto, no meio do verso. Portanto, a utilização de "uerum ubi" na abertura de parágrafo é indiscutivelmente mais canônica e avalizada do que "uerum cum", seja em função da posição inicial, seja em função do número de ocorrências entre os antigos.

2) "ac" por "et": trata-se, na verdade, de uma modificação que se repetirá com certa freqüência, ao longo de todo o volume. Com efeito, Gouveia reduz quase à metade o uso de “ac", forma contracta de "atque": em 1539, há dez registros, sendo 3 no prefácio em prosa e mais 7 nos versos dos epigramas; em 1540, há ao todo seis registros, sendo 4 nos versos e 2 no posfácio em prosa. Segundo dicionários e estudos de estilística clássica, a conjunção "et" é mais neutra, normalmente de caráter coordenativo, representando uma simples copulativa, ao passo que "atque" ou "ac" tem caráter mais subordinativo, apresentando uma conseqüência ou uma particularização do que foi dito antes, embora também possa ser usada como simples conjunção aditiva. Provavelmente em atenção a esse detalhe semântico é que Gouveia tenha revisto e alterado as conjunções inicialmente empregadas. Na troca em caso, "clari" e "nobiles" são meros sinônimos, utilizados em dupla para efeito de amplificação, e assim, do ponto de vista canônico, a união entre os dois adjetivos seria feita, de maneira mais recomendável, com a conjunção "et" do que com "ac".

3) "referebam" por "conferebam": aqui parece tratar-se de uma simples correção, segundo os valores semânticos clássicos, pois o verbo "confero" é que tem o sentido de "dirigir ou aplicar a atenção, a mente ou o pensamento" a algum lugar (regido pela preposição “ad"); o verbo "refero" não tem essa carga de significado, como se pode verificar em dicionários da língua latina.

Além das modificações relacionadas ao vocabulário, há mudanças na construção dos parágrafos, tanto na disposição dos termos, quanto na estrutura sintática. Selecionamos duas alterações para análise. A primeira é uma simples mudança na ordem das palavras, no início do segundo parágrafo, causada pela transformação do sintagma "in hoc genere", que passa a "hoc in genere". Dois motivos podem ter gerado a troca, ambos relacionados a uma 
preocupação poética com a composição do texto, em termos de harmonia sonora e de disposição intencional das palavras: no plano da sonoridade, a troca evitou o choque das consoantes oclusivas "c/g", promovendo a fluência no encontro entre as palavras, seja pelo encontro consoante-vogal de "hoc/in" ou pelo encontro suave de consoante nasal com oclusiva (n/g); no plano da colocação das palavras, a nova versão se afasta da fórmula prosaica, em que a preposição antecede o sintagma, e adota uma disposição típica da poesia, numa intencional anástrofe, em que a preposição é colocada no interior do sintagma que ela rege.

A segunda alteração a comentar é de caráter sintático: a mudança da construção “concludere laborabam" por "ut includerem laborabam”, no início do primeiro parágrafo (por volta da segunda linha). O motivo não nos parece muito evidente, pois, de fato, o verbo laboro admite, entre os clássicos, os dois tipos de complementos, regendo tanto o infinitivo quanto a oração subordinada com conectivo "ut/ne". Entretanto, cabe notar que, em Cícero, a larga preferência é pela construção com conjunção e oração subordinada; aliás, as quatro ocorrências da forma "laborabam", na primeira pessoa do singular do imperfeito do indicativo, entre os clássicos, estão em Cícero; nas quatro, há o uso da oração com conjunção. Considerando a estatística, e a importância que Cícero detinha no Renascimento, como modelo maior da boa prosa latina, é possível que esse tenha sido o fator preponderante. Também deve ter pesado o fato de que a versão de 1540, por usar o verbo conjugado na primeira pessoa (includerem), reforça o foco no sujeito, isto é, no sacrifício pessoal de Gouveia, ao passo que o complemento com infinitivo (concludere), além de não ter esse componente, poderia, em último caso, induzir a uma leitura equivocada e ambígua, em que o sujeito do infinitivo fosse o pronome $i d$.

Finalmente, não podemos deixar de comentar o corte do trecho final do parágrafo, que trazia um período confuso e excessivamente pessoal, até mesmo com alguns termos ambíguos, numa digressão desnecessária. Sua retirada melhorou a fluência do texto e permitiu uma melhor passagem do segundo para o terceiro parágrafo.

Todas essas análises tendem a apontar na mesma direção já antes anunciada: a edição de 1540 empreendeu uma verdadeira revisão do volume do ano anterior, buscando apoiar a composição do texto em alternativas mais típicas do cânone e mais freqüentes nos autores modelares. As alterações revelam uma preocupação com a erudição implícita no texto, com o bom acabamento da prosa e com o melhor uso de recursos retóricos e poéticos apropriados. 
Passemos agora ao exame das composições poéticas, utilizando, para isso, epigramas que foram publicados originalmente em 1539 e republicados, com modificações, em 1540. É justo que se diga que o historiador Luís de Matos já realizou um importante levantamento comparativo das duas versões da obra epigramática gouveiana, apontando que 47 poemas são repetidos de uma edição para a seguinte, na grande maioria com modificações, cujo alcance varia entre a sutilíssima intervenção e a reforma profunda. ${ }^{83}$

Apenas quatro poemas são repetidos sem nenhuma alteração, o que nos leva a crer que teriam passado pelo rigoroso crivo do humanista português. Os quatro poemas reeditados sem alterações são: “Ad Catharinam Bofremontanam” (em 1539, epigr. I, 1; em 1540, epigr. 2); o primeiro “Ad Andream Gouueanum Fratrem” (em 1539, epigr. I, 3; em 1540, epigr. 5); “Ad Ianum Habertum" (em 1539, epigr. II, 27; em 1540, epigr. 80); e o epitáfio “D. M. Ioannis Alberti" (em 1539, epigr. II, 30; em 1540, epigr. 82).

Contudo, mesmo o poema dedicado a André de Gouveia tem pequeníssimas correções, desconsideradas por Matos: em primeiro lugar, a alteração, generalizada na segunda versão, do sobrenome Gouueanus, que o poeta passa a grafar Goueanus, como já se afirmou; além disso, ele corrige a grafia de "solicitus", no verso 2, que assim fora grafado por óbvio erro tipográfico, emendando-o para "sollicitus"; finalmente, acrescenta uma vírgula no fim do segundo verso, isolando o sintagma "genio sine", alteração que não é, com efeito, completamente irrelevante, pois indica a leitura correta e o valor a nosso ver concessivo da expressão; aliás, a preocupação em corrigir uma vírgula já revela o rigor da revisão empreendida pelo humanista português e, igualmente, seu domínio do uso da pontuação e sua consciência acerca dessa questão, num período histórico de primórdios da indústria tipográfica em que poucos na Europa poderiam se gabar de ter o mesmo nível de conhecimento acerca do assunto.

Além desses poucos poemas mantidos na íntegra, há composições com uma única alteração, caso do epigrama "De Catello" (epigr. I, 21, em 1539; epigr. 24 em 1540), cuja única mudança é uma troca de posição entre as palavras urbis e nomen; o mesmo ocorre com o epigrama "Venus" (epigr. I, 26, em 1539; epigr. 31 em 1540), na posição de qui e me; de forma similar, no poema a Catherine de Beauffremont (epigr. I, 49, em 1539; epigr. 51 em 1540), há somente uma troca de palavra (xeniis passa a xenio); também só há uma mudança de posição de palavras no epigrama em memória de Francesca Perusia (epigr. II, 38, em 1539;

${ }^{83}$ Cf. Matos, Sobre António de Gouveia e a sua obra, pp. 26-31. 
epigr. 87 em 1540), entre siquidem e poterat, embora nele se registrem mínimas alterações na pontuação. Outro poema com uma única alteração é o segundo poema dedicado a André de Gouveia, irmão do poeta (epigr. I, 39 em 1539; epigr. 45 em 1540): a troca da palavra “Accepi" por "Quem cepi".

Existem, por outro lado, poemas muito modificados, quase irreconhecíveis na nova versão, como o epigrama aos amigos (epigr. I, 8 em 1539; epigr. 8 em 1540), o primeiro poema a Zébédée (epigr. I, 20 em 1539; epigr. 28 em 1540), e a composição a Antoine Arlier (epigr. II, 26 em 1539; epigr. 79 em 1540).

Dentro desse conjunto de epigramas modificados, optamos por selecionar algumas composições para análise, a fim de averiguar, mais uma vez, os princípios e os parâmetros das mudanças. Mantendo a ordem de aparição em que se encontram no volume de 1539, comecemos pelo epigrama I, 5, que passou a epigrama 11, em 1540:

[5]

\section{M. IOANNIS BAROLLAE}

In quo certarunt Fortuna, Scientia, Virtus,

Barolla exiguo conditur hoc tumulo.

At uiuos inter Fortuna, Scientia, Virtus,

Casurum nullo tempore nomen habent.

Si quaeris quid non una sint ista sepulta,

Exiguo a tumulo non potuere capi.

\section{M. IOANNIS BAROLLAE SENATORIS BVRDIGALENSIS}

In quo certarunt Fortuna, Scientia, Virtus,

Barollae exiguus contegit ossa lapis.

Illa tamen, memori si quid modo fidimus aeuo,

Casurum nullo tempore nomen habent.

Si quaeris tumulo quid non condantur eodem:

Exiguo a tumulo non potuere capi. 
A primeira mudança a comentar é a do título, com a indicação do cargo honorífico do retratado ao lado de seu nome; esse tipo de acréscimo foi feito de modo geral, por Gouveia, na revisão do livro, revelando maior atenção do autor ao prestar as homenagens poéticas, bem como um cumprimento mais explícito das praxes laudatórias.

Passando ao texto, a versão inicial do epigrama era baseada, sem dúvida, na estratégia da repetição, para o que colaboravam, notadamente, os versos 2 e 3, justamente os mais modificados na nova versão. Aparentemente, Gouveia quis evitar o excesso de reiteração e, sobretudo, uma reiteração ipsis litteris, raríssima de acontecer na obra desse poeta, que sempre recorre ao poliptoto. Assim, tendo mantido o verso final, que abre com "exiguo a tumulo", Gouveia optou por excluir esse sintagma do segundo verso. Da mesma forma, ao manter "Fortuna, Scientia, Virtus" no primeiro verso, excluiu esse sujeito composto do terceiro verso. Ao mesmo tempo, o poeta transferiu o termo "tumulo" para o quinto verso; neste caso, considerou mais apropriado manter uma figura de repetição no último dístico, com a aproximação das duas ocorrências dessa palavra. Na construção desse novo quinto verso, recorreu ao vocabulário do extinto segundo verso, de onde retirou não somente a mencionada palavra "tumulo", mas também o verbo "conditur", conjugado agora como "condantur". Tirando tais alterações, o quinto verso continuou muito parecido com a forma anterior, mantendo a mesma estrutura sintática do período "si quaeris quid non", que se repete, modificado apenas pela simples interpolação de "tumulo".

Como dito acima, os versos 2 e 3 foram os mais modificados (ao passo que os versos 1, 4 e 6 foram mantidos intocados). Além das mudanças comentadas antes, chama a atenção a exclusão do início do terceiro verso, cujo primeiro cólon, antes da cesura pentemímere, era "at uiuos inter". A troca de "at" por "tamen" pode ser justificada pela referência canônica diferente entre os antigos; com efeito, comparando "at" e "tamen", a primeira conjunção era mais empregada que a segunda por Plauto, Catulo, Virgílio e Propércio, enquanto Marcial e Ovídio usavam muito mais "tamen" do que "at". Considerando que os epigramas são modelados sobretudo em Marcial, e levando em conta, ainda, a influência de Ovídio sobre a poética gouveiana, esses fatores podem ter sido decisivos, sem falar da própria construção do verso em si. Aliás, na obra como um todo, há uma redução no uso de "at" (passa de 4 a 3 ocorrências) e um correspondente aumento de "tamen" (de 6 a 8 ocorrências).

Para preencher os versos 2 e 3, o humanista português teve a grande intuição e erudição de recorrer a Ovídio e Virgílio, por meio de alusões aos Amores e à Eneida. 
No caso de Ovídio, Gouveia faz alusão ao poema II, 6, em que Ovídio canta a morte do papagaio de uma jovem. Em que pese o caráter genérico da composição, especialmente de seu tema, trata-se de um poema sepulcral, hiperbolicamente laudatório, louvando a modesta figura do papagaio e seu refinado dom da fala. Desse poema Gouveia extraiu parte do vocabulário e da construção dos versos 2 e 3, como se pode ver pela comparação com o dístico ovidiano (Amores, II, 6, vv. 59-60):

Ossa tegit tumulus - tumulus pro corpore magnus quo lapis exiguus par sibi carmen habet:

Gouveia reformulou o dístico, aproveitando o mote do "lapis exiguus" num contexto bem alterado. Ao mesmo tempo, faz recair sobre o homenageado, um senador de Bordeaux, não apenas toda a louvação do poema original (por vezes inapropriada), mas sobretudo a conclusão de Ovídio, exposta nos dois versos a seguir, que realçava o dom da eloquiência do pássaro, um atributo cujo elogio é muito decoroso em se tratando de um parlamentar.

No caso de Virgílio, Gouveia recorreu à passagem que narra a morte de Euríalo e Niso, no campo de batalha dos rútulos, notadamente os versos 446 e 447 do canto IX, como se vê a seguir:

Fortunati ambo! si quid mea carmina possunt, nulla dies umquam memori uos eximet aeuo,

Desses dois versos, Gouveia retirou outra parte da idéia de composição do epigrama, aproveitando a locução "memori aeuo" e a construção condicional "si quid". A alusão é inteiramente adequada, pois recupera o momento em que a notícia da morte dos dois combatentes alcança os troianos, quando Virgílio declara a função da poesia de preservar a memória do feito heróico. Assim, o humanista português consegue fazer uma dupla associação: por um lado, torna Yberrola um herói digno de uma epopéia; por outro lado, torna o epigrama um canto fúnebre à altura de uma Eneida. De uma forma e de outra, resulta daí uma enorme elevação da importância do poema e um enaltecimento amplificado da figura do senador bordalês. Conseqüentemente, as alterações realizadas no epigrama, ainda mais graças às alusões, engrandeceram e refinaram o texto. 
O segundo poema cujas mudanças desejamos comentar é o epigrama dedicado a Jean de Lacroix, de caráter paródico, moldado sobre uma alusão a Marcial. Trata-se do epigrama I, 28 em 1539; epigrama 34 em 1540:

[28]

\section{AD IOANNEM CRVCEVM}

Argutis Epigrammatum libellis

Toto notus in orbe Martialis

Quaeris qui fuerit, negasque notum,

Argutis licet usque et usque chartis,

Extremis hominem fuisse terris.

Mendaci arguis, et tenes aperti:

Hispanum tamen esse schema nescis.

IOANNI CRVCEO

Argutis epigrammatum libellis

Toto notus in orbe Martialis

Quaeris qui fuerit, negasque notum,

Argutis licet usque et usque chartis,

Ignotis hominem fuisse terris.

Mendacem arguis, ac tenes aperte:

Hispanum tamen esse schema nescis.

Há mudanças apenas nos versos 5 e 6 . No verso 5, a troca de extremis por ignotis parece acrescentar sal e agudeza ao epigrama, pois transita justamente pelo campo semântico do poema como um todo, e amplifica a brincadeira espirituosa ao criar uma antítese ("notum - ignotis"), repetindo, por oposição, os dois termos anteriores (notus, no verso 2, e notum, no verso. 3). A graça é ainda maior se pensarmos no paradoxo de ser conhecido em terras desconhecidas, uma impossibilidade em si. 
Em relação às trocas efetuadas no penúltimo verso, a substituição de mendaci (genitivo do substantivo mendacium) por mendacem (acusativo de mendax) parece melhorar a sintaxe, que se torna mais de acordo com o padrão dos textos clássicos, pois o verbo arguo até aceita genitivo de delimitação da acusação, mas este seria apenas um complemento do acusativo, que é a regência obrigatória e, nessa hipótese, deveria vir em primeiro lugar, numa construção do tipo "acusar alguém de algo"; portanto, o uso de "mendacem" é mais canônico. Essa troca conduz à adaptação de aperti para aperte, uma vez que, sem o substantivo mendacium, não há como manter o adjetivo "aperti", que, antes, concordava com ele. Finalmente, a troca de et por $a c$, no mesmo quinto verso, realiza o movimento inverso ao do conjunto da obra, em que houve a redução de "ac", trocado por "et". Mas, neste caso, há duas justificativas razoáveis: primeiro, o emprego de $a c$, neste caso, corresponde ao uso da conjunção entre os antigos, pois aqui, de certa forma, a ação "tenes aperte" está contida na ação "mendacem arguis", ou, pelo menos, se liga intimamente a esta, que acarreta aquela; segundo, a troca evitou a duplicação do "t" que ocorria com "et tenes", e, ao que parece, não foi considerada adequada pelo poeta.

O próximo poema a ser examinado é o epigrama I, 37, que passa a epigrama $40 \mathrm{em}$ 1540. Essa composição, dedicada ao humanista Étienne Dolet, importante poeta neolatino da Renascença francesa, já foi analisada no capítulo anterior. Vejamos as duas versões:

\section{AD STEPHANVM DOLETVM}

Quid te non laudem, credo, Dolete, requiris,

Id me tu melius facis.

\section{STEPHANO DOLETO}

Te quid non laudem forsan, Dolete, requiras.

Id me tu melius facis.

Registram-se alterações somente no primeiro verso. Observemos, primeiramente, a troca de "Quid te" por "Te quid". Em termos métricos, isso não altera o espondeu inicial do hexâmetro. Mas parece que há vantagens na troca. Primeiro, evita-se o choque entre as dentais 
$\mathrm{d} / \mathrm{t}$ (quid te), pelo mais suave encontro d/n de "quid non". Ademais, a sequência "quid non" é mais comum, nos poetas clássicos estudados, do que "quid te", na proporção de 44 para $26^{84}$. Quanto a "quid te", é quase que só usada em diálogos, isto é, em discurso direto, ou em expressões cristalizadas, como na interrogação "Quid te iuuat?", que responde por quatro das cinco presenças em Marcial. Assim, a troca também é recomendada (ou respaldada) pela tradição clássica. Uma terceira vantagem é a ênfase obtida sobre "Te", quando o pronome passa a iniciar o verso. Essa posição é extremamente enfática, e, no corpus estudado, é uma posição pouco comum do pronome pessoal no verso, sempre por ênfase. Portanto, a troca permite a Gouveia topicalizar justamente o pronome (que se refere ao destinatário da sátira, Dolet), tendo assim um efeito mais incisivo, mais direto e mais preciso do que na situação anterior. Todas esses vantagens preponderaram sobre as perdas decorrentes da alteração, que extinguiu, por exemplo, o paralelismo "quid te / id me", ainda que o jogo referencial seja mantido, agora como quiasmo (te quid / id me).

A troca de "credo" por "forsan", palavra que se encontra no centro do verso, e está ainda mais destacada por ocupar uma posição privilegiada, entre as cesuras pentemímere e heptemímere, também parece ter sido apoiada na utilização convencional clássica. De fato, credo é muito mais recorrente do que forsan, pois aparece 285 vezes no corpus, contra apenas 18 presenças de forsan. Porém, das 285 presenças, cerca de 240 são nos comediógrafos Plauto e Terêncio. Conseqüentemente, o termo acaba se identificando com uma linguagem específica, a cômica, e com o registro coloquial. Provavelmente para evitar a intromissão de um registro coloquial, de matriz cômica, no epigrama destinado a Dolet, é que Gouveia tenha optado pela substituição pelo bem mais raro "forsan", nunca utilizado pelos comediógrafos, e com apenas 18 aparições, distribuídas somente entre Horácio (1), Marcial (6), Ovídio (7) e Virgílio (4). A troca também evitou a cacofonia "do-do", resultante do encontro "credoDolete", e a harmonia sonora deve ter pesado, mais uma vez, para determinar a substituição.

A mudança de credo por forsan provocou a alteração sintática do verbo final, passando o presente do indicativo "requiris" a presente do subjuntivo "requiras". A mudança do modo verbal não seria obrigatória, de acordo com a gramática clássica, mas deve ter sido

${ }^{84}$ Todas as proporções e freqüências de termos apontadas neste trabalho foram obtidas pelo uso da ferramenta de busca do programa Musaios. Adotamos, como corpus de investigação, os poetas clássicos mais referidos por Gouveia ou mais aceitos pelo cânone tradicional, a saber: Catulo, Horácio, Propércio, Tibulo, Virgílio, Ovídio, Marcial e os cômicos Plauto e Terêncio. 
decidida por Gouveia para, mais uma vez, se aproximar dos modelos desejados, em função do interlocutor do epigrama. Com efeito, o presente do indicativo "requiris", além do célebre dístico de Catulo ("Odi et amo. Quare id faciam, fortasse requiris"), é muito freqüente em Marcial. Já o subjuntivo "requiras" aparece, em final de verso, nas Heróides (XV, 5) e na Eneida (II, 506), nos dois versos combinado com o advérbio "Forsitan", que abre o verso. É possível, portanto, que Gouveia tenha preferido respaldar seu verso em autores mais prestigiados, como Ovídio e Virgílio, e tenha se afastado intencionalmente de referências a Catulo ou Marcial, ainda que na composição de um epigrama. ${ }^{85}$ Ademais, o uso do subjuntivo para acompanhar o advérbio pareceria mais castiço e mais correto, gramaticalmente, na medida em que se afasta da coloquialidade. Cabe notar que é justamente a tendência em direção a um registro mais gramaticalizado e erudito que caracteriza, de modo geral, a revisão de 1540.

Contudo, passemos agora ao próximo exame, do epigrama II, 6, em memória do advogado Jean Montagne, que passa a epigrama 67:

[6]

\section{M. MONTANI IVRISPERITI}

Montanus trepidos media de morte trahebat,

Viribus eloquii consiliique reos.

Mors regnum, lucrumque Charon, duraeque Sorores

Clamabant uires succubuisse suas.

Nec mora, Montanum rapiunt sine legibus ullis.

$\mathrm{Ah}$, non sic fatis abstulit ille reos.

[67]

D. M. IOANNIS MONTANI IVRISPERITI

Montanus trepidos media de morte trahebat

${ }^{85}$ Não se trata apenas de uma questão de prestígio, mas também do fato de que Gouveia estava, naquele ano, estudando e editando justamente as obras desses dois poetas, Ovídio e Virgílio. 
Viribus eloquii consiliique reos.

Lugebant erepta sibi sua numina Parcae,

Nec uolui fusis ferrea fata suis.

Haud mora, Montanum rapiunt sine legibus ullis.

Ah non sic fatis abstulit ille reos.

Como já foi observado, durante a análise deste epigrama, no capítulo anterior desta tese, a principal mudança se dá no dístico intermediário. Se a abertura e o desfecho do poema pareceram agradar a Gouveia (e, de fato, como vimos, os versos são metodicamente construídos, com a agudeza e a brevidade próprias do gênero, num tom quase sentencioso, e ainda com o uso de elementos retóricos bem escolhidos), o miolo do epigrama não condizia com as intenções do poeta. De fato, se compararmos as duas versões, veremos que a primeira é muito mais floreada e carregada, seja por causa do epíteto "durae Sorores", seja pela enumeração em polissíndeto do terceiro verso. Além disso, o quarto verso exibe um certo desequilíbrio, com verbos pendendo para a esquerda (o primeiro, com três sílabas, e o segundo, no infinitivo passado, com cinco sílabas), em contraste com termos nominais curtos, dissílabos, à direita.

Em compensação, o novo dístico é mais simples, mais direto e mais equilibrado. Já não há a desnecessária e pesada enumeração, substituída pelo termo essencial, "Parcae", agora em elocução direta e não em epíteto. O quarto verso está mais equilibrado, com palavras de extensão aproximada, e Gouveia se permite até uma aliteração em /f/ (fusis ferrea fata). Outro jogo poético ocorre no terceiro verso, na seqüência em poliptoto (diptoto) "sibi sua", separados pela cesura principal (heptemímere) do verso.

A substituição do dístico ainda evitou dois inconvenientes: o uso do verbo clamabant, muito mais vulgar que lugebant (mais solene e apropriado a um epitáfio); e a repetição do uso do substantivo uires, que tinha sido associado a Montagne no segundo verso, e, reutilizado no terceiro verso, indicava uma incondizente falta de atenção, pois passava então a ser relacionado aos seres infernais; a troca por numina eliminou esse problema.

Além do dístico intermediário, totalmente alterado, há apenas uma mudança: no quinto verso, "Nec mora" é trocado por "Haud mora". A explicação, a nosso ver, estaria relacionada, mais uma vez, com o uso tradicional: quanto a "nec mora", muito mais frequente que "haud mora" (na proporção de 48 para 9, no corpus estudado), sintagma marcado como iniciador de verso (47 das 48 presenças, pois apenas uma vez, nos Fasti, não é inicial), seu uso está 
claramente associado a Ovídio, responsável por 39 dos 48 empregos. Já "haud mora”, além de mais raro, deve ser associado a Virgílio, pois é neste poeta que se registram 8 das 9 presenças dessa expressão no corpus clássico.

Parece-nos, portanto, que se tratou de uma opção poética de buscar em Virgílio, e não mais em Ovídio, o referencial vocabular para a construção do epitáfio.

Talvez, até, a intenção de Gouveia fosse recusar a vinculação desse verso com uma possível matriz, o verso III, 2, 93, das Pônticas, que se pode ler a seguir:

Nec mora, de templo rapiunt simulacra Dianae

Assim, Gouveia quis desfazer qualquer idéia de alusão que pudesse ser vislumbrada no seu verso, e recorreu ao vocabulário específico e marcadamente virgiliano para rechaçar o modelo ovidiano.

Examinemos, agora, o epigrama II, 9, de 1539, que foi republicado em 1540, com o número 68:

\section{AD LECTOREM}

Pauca damus, fateor, sed inepta epigrammata, Lector:

Ergo multa nimis dicere iure potes.

Pauca damus, fateor, sed inepta epigrammata, Petre.

An non multa nimis dicere iure potes?

Houve a mudança da dedicatória do poema, que deixa de ser ao leitor e passa a ser ao colega de estudos clássicos e conterrâneo Pedro Álvaro, com a correspondente alteração no vocativo do primeiro verso, de Lector a Petre. A troca do vocativo melhorou muito a harmonia sonora, prolongando a aliteração em /p/ e evitando a única consoante líquida do 
epigrama, sem a perda da consoante /t/, que forma a segunda aliteração do epigrama. Note-se que a consoante inicial /p/, de Petre, permite uma coesão muito forte da composição, pois estabelece um elo entre as três palavras em posição-chave na peça, isto é, "Pauca" (primeira palavra), "potes" (última palavra) e "Petre" (última palavra do primeiro verso). Cabe notar, ainda, o eco sonoro propiciado pelas consoantes de "Petre" e "potes", garantindo o paralelismo entre as duas palavras em posição final de verso e, por extensão, entre os dois versos.

A outra alteração do epigrama diz respeito ao início do segundo verso, com a troca da conjunção "Ergo" pela partícula interrogativa "An non". Cabe observar que Gouveia, ao rever a obra, procurou excluir a conjunção ergo dos poemas; com efeito, o termo foi empregado dez vezes nos epigramas de 1539, e, em 1540, surge somente uma única vez, no epigrama 19, e, mesmo assim, sem valor consecutivo. Ao eliminar a conjunção das composições, decerto Gouveia associou seu uso à prosa oratória e se desfez desse vocábulo que, a seu ver, seria próprio de um texto argumentativo, e não poético. A solução encontrada foi substituir a oração consecutiva por uma interrogativa, numa forma elegante de passar a palavra e a importância ao interlocutor Pedro Álvaro. Aliás, a mudança de frases fortemente assertivas para frases interrogativas ocorre em outros poemas da obra, suavizando um tom que poderia parecer, em certas situações, excessivamente petulante, como no poema sobre Briand de la Valée.

Voltemos nossa atenção, presentemente, ao epigrama II, 22, republicado em 1540 como epigrama 38:

\section{AD POSTHVMVM}

Contentus esse filiabus, Posthume,

Auctus duabus, sorte iam potes tua.

Nam si neque dimidium petebas unius,

Plus quam petebas accepisti, Posthume. 


\section{POSTHVMO}

Contentus esse filiabus, Posthume,

Auctus duabus, sorte iam potes tua.

Plus quam petebas accepisti, Posthume.

A única alteração foi a eliminação do terceiro verso da composição original; isso, aliás, só foi possível porque o poema não foi composto em dísticos elegíacos, mas usando o escazonte como metro.

A supressão desse único verso alterou completamente o perfil do epigrama, substituindo o caráter jocoso original, carregado de sarcasmo excessivo e, sob certo ponto de vista, deselegante, por um gracejo leve, relativamente comemorativo do nascimento das filhas. Com efeito, a possível indelicadeza do poema provinha do fato de que, no verso suprimido, Gouveia afirmava que Póstumo não desejava ter filhos; e a forma como isso vinha escrito, "neque dimidium unius", era extremamente mordaz e estranha, ao invocar a imagem de um "meio filho" (ou "metade de um filho"). Além do mais, o fato de "unius" ser uniforme para os três gêneros, em associação com o termo filiabus (indicando claramente que se tratava do nascimento de filhas mulheres, e não de filhos em geral) induzia à interpretação de "unius" como referente ao gênero feminino; ou seja, a compreensão mais plausível do texto seria a de que Póstumo não desejava nem sequer "meia filha", quanto mais duas. De todo modo, a inconveniência da brincadeira estava, portanto, em insinuar que filhos (ou pior, segundo a leitura provável do poema: filhas) eram indesejados. Além de inconveniente, o verso era contraditório com o teor de um poema que visava a comemorar, de modo chistoso, o nascimento de duas filhas. A eliminação do verso problemático suavizou em muito o epigrama: na nova versão, diz-se apenas que Póstumo recebeu mais do desejava (i.e., duas filhas), dando a entender que um filho não era indesejado, e que a única surpresa estava em receber, de uma só vez, duas filhas.

Além do mais, a supressão do verso não comprometeu o desenvolvimento do epigrama; ao contrário, aquele verso dispensável não fez nenhuma falta ao entendimento e ainda permitiu que a conclusão se aproximasse dos dois versos iniciais, que funcionam como abertura e proposição do problema, resolvido, com agudeza, no verso final (como, aliás, já 
ocorria). Assim, também no exame da distribuição das partes do epigrama, a eliminação melhorou o poema, deixou-o mais enxuto e com o arremate mais rápido e mais contrastante (pela proximidade) com a introdução, pois o verso suprimido acabava funcionando como uma digressão mal colocada.

Passemos, finalmente, ao epigrama II, 40, posteriormente epigrama 89, último desta amostragem de possibilidades de leitura e interpretação que se abrem com a análise das alterações efetuadas por Gouveia na revisão da sua obra.

\section{AD IACOBVM BELNAEVM}

Ecce repente uno felix dat Gallia partu,

Doletum Iambico trucem:

Macrinum curua gnarum testudine, Diuum

Restinguere ardenteis minas:

Borbonium Latiis salibusque, iocisque fluentem,

Nugisque gratum seriis:

Vosque o Vultei, Brixi, Marthane, Ducheri,

Sacrae decora Poeseos.

Quaeris quid facio? numero, Belnaee, poetas,

Quos Gallia protulit ferax.

\section{IACOBO BELNAEO}

Ecce repente ferax uno dat Gallia partu

Doletum iambico trucem,

Macrinum curua narum testudine Diuum

Restinguere ardentes minas,

Borbonium Latiis salibusque, iocisque fluentem

Nugisque gratum seriis,

Vosque o Vultei, Brixi, Marthane, Ducheri, 
Sacrae decora Poeseos.

$\mathrm{Si}$, quid agam, nescis, numero, Belnaee, Poetas,

Quos Gallia protulit ferax.

Há duas alterações relevantes: a troca de felix por ferax, no primeiro verso, com reposicionamento da palavra; e a mudança sintática no penúltimo verso, com um novo período introdutório do verso. No caso de "felix / ferax", sem dúvida Gouveia quis ressaltar a qualidade de geratriz da França; embora felix tenha esse primeiro sentido, e seja até mesmo cognato de ferax, é certo que os sentidos conotativos de felix (feliz, afortunado, benfazejo) são preponderantes no uso da palavra; assim, para destacar o valor específico da França desejado no poema, de "profícua", o emprego de ferax é melhor e mais preciso. A troca trouxe vantagens adicionais: provocou a repetição intencional desse termo no poema, pois ele já fazia parte do epigrama, sendo a última palavra do texto, numa posição já por si mesma realçada; além do novo realce, pela reiteração, aumentou-se a coesão interna da peça, com remissão do primeiro ao último verso, em circularidade.

Quanto à eliminação de "Quaeris quid facio", o motivo não parece claro, mas defendemos que tenha ocorrido para se adaptar ao padrão gramatical clássico, que determinaria o uso do modo subjuntivo para o verbo "facio", uma vez o termo está no interior de uma oração interrogativa indireta. A forma canônica seria, portanto, "quaeris quid faciam”. Em lugar de fazer uma simples correção da desinência verbal, o poeta decidiu apagar toda a frase, e substituí-la pelo período "si, quid agam, nescis", o qual, aliás, traz o verbo "agam" corretamente empregado no subjuntivo, segundo o padrão normativo do latim clássico.

$$
* * * * *
$$

O objetivo deste capítulo da tese foi o de extrair algumas conclusões quanto ao processo de composição poética de Antônio de Gouveia, aproveitando a particularidade da dupla publicação de sua obra, numa abordagem que procura se aproximar do que se convencionou denominar "crítica genética". De fato, a edição em anos consecutivos, sob a revisão atenta do autor, nos permitiu vislumbrar procedimentos poéticos e critérios estilísticos que nortearam as escolhas literárias do humanista português, numa fase prévia à publicação "definitiva" de 1540. 
Pudemos notar um uso mais preciso do vocabulário, uma sintaxe mais límpida e, ao mesmo tempo, mais canônica e mais padronizada, e um maior planejamento do conjunto da obra, bem como a minúcia de suas preocupações refletida nas correções de ortografia ou pontuação, o rigor mais refinado na redistribuição das palavras, na construção do verso, na utilização de figuras e no emprego de recursos de sonoridade, e o perfil mais solene e erudito da obra, mas sem o comprometimento da leveza e da fluência próprias do gênero epigramático.

Todas essas alterações remetem para uma grande conclusão geral: na revisão da obra, Gouveia aumentou significativamente o diálogo intencional com os textos clássicos, e normalmente apoiou as mudanças em referências encontradas em autores antigos, que procurou imitar e emular. Nesse sentido, as alusões que fez não são meramente ornamentais, mas essenciais para a produção dos efeitos de sentido desejados. Muitas modificações somente podem ser entendidas se levarmos em consideração essa intertextualidade, e isso revela um fortalecimento da presença clássica em sua obra, na passagem de um ano para o seguinte.

No entanto, cabe lembrar que, por ironia do destino, foi a versão de 1539 que teve maior circulação, sendo a base da antologia organizada em Paris, em 1555, com a recolha dos poemas dos principais epigramatistas europeus do Renascimento, e da reedição de 1748, no bojo do grandioso projeto Corpus Illustrium Poetarum Lusitanorum qui latine scripserunt, de Antônio dos Reis. 


\title{
PARTE II
}

\author{
A obra poética neolatina \\ de Antônio de Gouveia
}




\title{
Capítulo 4
}

\section{EDIÇÃO DO TEXTO LATINO}

\author{
DA OBRA POÉTICA \\ $\mathrm{DE}$ \\ ANTÔNIO DE GOUVEIA
}

\section{(EPIGRAMÁTICA E EPISTOLAR)}

Apresenta-se a seguir o texto latino das obras analisadas na presente tese. Trata-se dos dois volumes de poemas que Antônio de Gouveia publicou em vida, nos anos de 1539 e 1540, intitulados, respectivamente, Epigrammaton Libri Duo e Epigrammata; Eiusdem Epistolae Quatuor.

Para a edição das obras, consultamos as publicações que se fizeram ao longo do tempo, a saber: para o primeiro volume de epigramas, intitulado Epigrammaton Libri Duo, dispusemos das quatro edições existentes da obra, segundo levantamento de Luís de Matos ${ }^{86}$, começando com a original, de 1539 (impressa por Sébastien Gryphe, em Lyon), e acrescentando a antologia feita na França em 1555, que abarca 58 epigramas (impressa por Corbinus, em Paris), a reprodução de 1748 (no Corpus Illustrium Poetarum Lusitanorum, organizado por Antônio dos Reis) e a compilação de 1766 (organizada por Van Vaassen, em Roterdam).

Para o segundo volume, intitulado Epigrammata; Eiusdem Epistolae Quatuor, dispusemos também das duas versões impressas da obra, a original, de 1540 (impressa por

\footnotetext{
${ }^{86}$ Matos, Sobre António de Gouveia e a sua obra, p. 15.
} 
Sébastien Gryphe, em Lyon), e a compilação de 1766 (organizada por Van Vaassen, em Roterdam).

Na edição do texto, procuramos seguir, a princípio, os critérios estabelecidos por Sebastião Tavares de Pinho, expostos nas páginas de sua tese de doutoramento sobre a obra de Lopo Serrão, De Senectute, posteriormente publicada pela INCM, em Lisboa. ${ }^{87}$ Cabe notar que tal proposta se coaduna com as normas editoriais mais recentes, adotadas na publicação de textos clássicos ou neolatinos, pelas principais casas editoriais do mundo, e observa os preceitos da importante coleção francesa da Sociedade "Les Belles Lettres", conforme dita o volume Règles et recommandations pour les éditions critiques ${ }^{88}$; ademais, foi referendada pela Associação Portuguesa de Estudos Neolatinos (APENEL), como parâmetro editorial na publicação de obras renascentistas.

O princípio básico preconizado por Pinho é a uniformização e correção dos textos originais publicados no século XVI, período em que predominava uma hesitação generalizada em relação às normas gramaticais, resultando em textos eivados de "arbitrariedades, aberrações e fantasias ortográficas" ${ }^{89}$. Nessa tarefa de revisão, Pinho propõe que sejam seguidas as mesmas normas de ortografia e pontuação obedecidas, atualmente, pelas mais respeitadas editoras universitárias, na edição de textos da Antigüidade Clássica. A principal justificativa para essa atitude é, segundo o acadêmico português, o respeito a uma evidente intencionalidade de imitação que os poetas novilatinos expunham em seus textos, ou seja, a possibilidade de "sintonizar com as preocupações dos latinistas do século XVI" os poetas renascentistas tiveram o empenho de imitar os autores clássicos, devemos respeitar essa disposição, e editar seus textos segundo a mesma norma que se aplica hoje aos autores antigos. Evidentemente, isso também auxilia grandemente no estudo dos poetas neolatinos, pois facilita tanto a leitura direta do texto quanto a comparação de suas obras com os seus respectivos modelos clássicos. Essa sugestão impõe, no entanto, uma revisão e uniformização, sobretudo, de dois aspectos do texto original: a ortografia e a pontuação.

\footnotetext{
${ }^{87}$ Vide: Pinho, Lopo Serrão e o seu poema Da Velhice, pp. 255-262.

${ }^{88}$ Règles et recommandations pour les éditions critiques (Série latine). Paris, Les Belles Lettres, 1972.

${ }^{89}$ Pinho, op. cit., p. 256.

${ }^{90}$ Idem, ibidem, p. 256.
} 
Em relação à obra de Antônio de Gouveia, porém, o avanço da pesquisa nos levou a limitar a abrangência da aplicação desse critério de edição, por dois motivos principais.

Em primeiro lugar, é digno de nota o fato de que Antônio de Gouveia detinha um domínio extraordinário das normas gramaticais e editoriais, até mesmo por conta de seu ofício como editor e comentador de textos clássicos numa das mais prestigiadas casas impressoras da Europa renascentista, a de Sébastien Gryphe, em Lyon. Ao contrário de muitos outros autores do Quinhentos, ainda dúbios na ortografia, como se vê em Portugal (e neste rol devemos incluir o mesmo Lopo Serrão cujo texto motivou o estabelecimento de critérios por Sebastião Pinho), Gouveia é absolutamente rigoroso e sistemático na edição de seu texto, que é inteiramente uniforme em termos de ortografia. $\mathrm{O}$ humanista português também demonstra um uso muito consciente da pontuação, e para provarmos isso basta que se recorde que uma das correções que ele faz, na errata do livro de 1539, diz respeito, unicamente, a um ponto final no término de um verso, que ele altera para vírgula.

Aliás, a leitura de suas obras, e a posterior comparação com outras publicações européias do século XVI, permite-nos verificar como o poeta português estava envolvido pelo ambiente humanista e como pode ser considerado um dos grandes eruditos do período, empregando a língua latina com muita consistência. Em termos editoriais, seu livro é notável e absolutamente moderno, seja pela escolha tipográfica, pela normatização ortográfica ou pela distribuição do texto. Não há o emprego de letras ramistas, nem se observam os múltiplos erros originados de derivações etimológicas incorretas, comuns em outros autores coetâneos. Portanto, sua própria obra, referida enquanto produto editorial, é mais uma das provas de sua arraigada formação humanística e de sua intensa participação na vanguarda renascentista francesa.

Nesse sentido, há muito pouco o que alterar no original de Gouveia, e algumas dessas modificações foram mesmo evitadas, pois, sendo desnecessárias no conjunto de uma nova edição, acabariam por acobertar alguns traços característicos das escolhas textuais do humanista lusitano.

Mas há um segundo motivo, muito peculiar ao trabalho investigativo que passamos a efetuar, que limitou a aplicação cega e abrangente da proposta formulada pelo professor Pinho. Trata-se da oportunidade de proceder à comparação de textos e à análise de alterações feitas pelo próprio autor, em virtude da forma como a obra de Gouveia foi publicada, isto é, em edições que vieram à luz nos anos consecutivos de 1539 e 1540. As modificações de caráter autoral, ocorridas entre as edições de 1539 e 1540, nos permitem vislumbrar os 
critérios estilísticos do poeta português, em termos de escolha vocabular, distribuição das palavras ou construção do poema.

Assim, evitamos fazer uniformizações ou mudanças que prejudicassem a exposição e análise do confronto. Conseqüentemente, qualquer palavra ou pontuação que tenha sido alterada pelo próprio autor, entre as duas edições referidas, foi mantida na forma original, e nos furtamos a realizar qualquer tipo de correção relacionada a elas.

Daí decorreram dois cuidados adicionais: o primeiro foi o de executar a edição final do texto de 1539 somente depois de compará-lo com o de 1540, e não apenas a partir do confronto das quatro diferentes publicações dessa obra (entre os séculos XVI e XVIII). O segundo cuidado foi o de procurar apontar, em nota de rodapé, as mudanças efetuadas em decorrência da presente edição do texto, até porque o volume delas não é grande, como se pode deduzir das considerações feitas acima.

Ainda assim, de maneira semelhante à edição realizada por Pinho, também aqui se fizeram certas correções de forma relativamente generalizada, como, por exemplo, concernente à ortografia:

a) a substituição do "y" por "i" em termos como "lachryma" ou "lacryma", que passam a "lacrima";

b) a introdução de geminadas em palavras como "literaria", que passa a "litteraria";

c) a restituição da grafia tradicional e substituição do "n" por "m", em palavras formadas originariamente pelo acréscimo de pronomes ou de partículas enclíticas, como em "nanque", que passa a "namque", ou "quicunque", que passa a "quicumque";

d) a retirada do trema nas várias ocorrências da palavra "poeta" bem como de todos os seus compostos ou derivados ${ }^{91}$.

Como recomendado por Pinho, foram seguidas, nas correções, as normas ortográficas de obras de referência na área de Estudos Clássicos, sobretudo o Oxford Latin Dictionary (OLD).

Por outro lado, não foram modificadas certas ortografias que podem ser consideradas alternativas e que assim figuram em obras de referência, como no próprio OLD, caso, por exemplo, do verbo "intelligo" (forma alternativa de "intellego"), do substantivo "caussa"

${ }^{91}$ Ao contrário das demais alterações ortográficas, a retirada do trema não foi indicada no aparato crítico. 
(alternativa de "causa") ou do advérbio "lubenter" (alternativa de "libenter"). Tais ortografias foram mantidas especialmente nas situações em que Gouveia se serviu delas de forma contínua e sistemática.

Em relação à pontuação, os mesmos motivos expostos acima nos levaram a limitar nossa intervenção, mas, ainda assim, decidimos interferir e proceder a alterações em duas situações:

a) Antônio de Gouveia não separa o vocativo por vírgulas, e isso aparece em sua obra de modo absolutamente sistemático e abrangente; porém, como as edições atuais de textos clássicos, e mesmo neolatinos, empregam vírgulas para separar os vocativos, e sabendo que o poeta português está imitando ou mesmo citando literalmente essas obras, pareceu-nos lógico adotar para o texto de Gouveia, nesse item, o mesmo critério das demais obras latinas e novilatinas, delimitando o vocativo com vírgulas;

b) o texto gouveiano, por outro lado, é rigoroso na separação das orações por vírgulas, o que gera um uso muito numeroso dessa pontuação, muito diferente do emprego atual; a presença exagerada da vírgula pode ser notada, especialmente, quando usada para separar orações coordenadas (as aditivas, por exemplo, são sempre separadas por vírgulas, que Gouveia coloca antes do "et" ou dos termos que recebem a enclítica “-que"), ou para separar as orações principais das subordinadas, no caso de completivas nominais, quando o emprego, pelas normas atuais, chega a ser considerado até mesmo um erro. Nessas situações, procurouse eliminar o que pudesse ser considerado um excesso de vírgulas, mas, como se procedeu a uma intervenção limitada (até mesmo por conta dos objetivos específicos da presente tese, apontados acima), é possível que a pontuação que tenha restado cause algum estranhamento aos leitores habituados com as regras atuais.

Essas ligeiras intervenções na pontuação não foram registradas em nota de rodapé, até porque elas se tornariam demasiado numerosas, se fossem feitas, por exemplo, para cada vocativo que aparece no texto, pois, como se explicou acima, Antônio de Gouveia é extremamente rigoroso e sistemático e nunca usa vírgulas nessa situação.

Relembramos que, em relação à ortografia, ao contrário, como se frisou acima, procuramos indicar todas as alterações efetuadas no texto, mesmo as mais constantes.

No registro das alternativas do texto, a fim de simplificar a exposição do aparato crítico, adotamos as seguintes letras para indicar as edições a que se referem: 
a) para o livro de 1539, Epigrammaton Libri Duo:

A: edição original de 1539;

A’: errata publicada na última página da edição de 1539;

B: edição de 1555 (recolha de somente 58 epigramas);

C: edição de 1748;

V: edição de 1766;

E: nossa proposta de edição.

b) para o livro de 1540, Epigrammata:

A: edição original de 1540;

V: edição de 1766;

E: nossa proposta de edição.

Como se vê, embora tenhamos seguido, na essência, as normas das edições críticas publicadas pela Sociedade Editorial "Belles Lettres", de Paris, especialmente no que diz respeito ao aparato crítico, procuramos adaptá-las para um uso mais prático e mais adequado ao teor do presente trabalho. 


\title{
ANTONII GOVVEANI
}

LVSITANI*

\section{EPIGRAMMATWN \\ LIBRI DVO}

\author{
AD MORTALITATEM
}

SUN THI HMERAI

\section{Lugduni}

Apud Sebastianum Gryphium

1539

* Gouueani Lusitani $A$ : Goueani $C V$; EPIGRAMMATwN $A$ : EPIGRAMMATVM $C V$; sun THI HMERAI A: deest $C V$. 


\title{
AD MORTALITATEM*
}

\author{
Mortalis ipse,
}

\author{
Gouueanus
}

omnia tibi haec sacrat mortalitas.

* Esta página, de número 2 na edição de 1539, não consta de nenhuma outra edição. 


\section{ANTONIVS GOVVEANVS IACOBO BELNAEO SALVTEM*}

1. CVM interim a grauioribus me cogitationibus recolligerem, si quid argute scribi posse uidebam, id epigrammate concludere laborabam: praesertim cum ad scribendum esset animus, esset ea facultas, quam usu quidem litterarum prope nullo partam, et conquisitam, exercitatio potuit aliqua confirmare, amicorumque accederet inani fortasse spe, incensa tamen, ac inflammata exhortatio.

2. Verum cum ad nouos et ueteres scriptores, qui in hoc genere clari ac nobiles extitere, cogitationem paulisper referebam, frangi me animo, debilitarique, nescio quomodo, sentiebam: qui nouitatis illos nomine non displicere, hos antiquitatis gratia probari plurimum intelligerem: quorum altero ad nostrorum laborum commendationem abuti non possem, altero ne uti quidem uellem.

3. Nam ut de Catullo initio dicam, magnus profecto uir fuit, multarum magnarumque artium cognitione instructus, multa subtiliter, multa grauiter inuenit, Romane scripsit non pauca, eius tamen scripta Catullo plurimum, Catullum suis scriptis parum debere statuebam. Quae si religionis metu deposito, quo nos impeditos ac irretitos tenet antiquitas, expendere uelimus, nihil quod ad ingenii acumen, orationis puritatem pertineat, fortasse desideres, cur noua esse non possint, non intelligas.

4. Hunc M. Val. Martialis, ut longo temporum secutus interuallo, ita uictum superatumque in omnes ingenii partes reliquit. De quo sic iudico: magnas esse huius uiri, et admirabiles in eo genere uirtutes, non quae aliorum possint industriam refringere, conatumque retardare.

5. Claudianus post multo laude, quam ex Panegyricis duobus tulerat, non contentus, ad hanc quoque aspirauit, cuius ne umbram quidem, meo iudicio, est assecutus.

6. Nostra et patrum memoria nimium multos tulit: qui neque ingenii commendatione, neque nouitatis gratia caruerunt.

7. Quae nobis etsi deesse uel non potest, uel certe non debet, ita est optanda, ut si nulla ingenii, nulla industriae, nulla dictionis uirtute commendetur, iubeam nihil esse ualituram.

* Título GOVVEANVS A: GOVEANVS cett. SALVTEM $C V$ : SAL. $A \quad 1 \quad$ litterarum $C V$ : literarum $A \quad 3$ debere statuebam $A C$ : debere, statuebam $V \quad 4$ M. Val. E: P. Val. cett. 
8. Mihi profecto factum abunde erit satis, haec si ita legas, ut intelligas, intelligas ut iudices, iudices ut uitiis minime concedas, neque uirtutes, quae sentio quam sint exiguae, suo fructu priuatas esse patiaris. Qua censura in posterum nos uel deterriti plane, uel certe retardati, ad scribendum paulo erimus tardiores. Vale. Lugduni III Calend. Maias.*

* 8 profecto $A C$ : profectum $V \quad$ Maias. $A C$ : Maias. MDXXXIX. $V$. 


\section{ANTONII GOVVEANI \\ LVSITANI $^{92}$}

\section{EPIGRAMMATON \\ LIBER PRIMVS}

[1]

AD CATHARINAM BOFREMONTANAM

Sume patrocinium nostri, Catharina, libelli,

Cum domino ualde qui cupit esse tuus.

Quod non ante dedi, dare nunc, Catharina, licebit:

In dominum scis me iuris habere nihil.

${ }^{92}$ GOVVEANI LVSITANI A: GOVEANI $C V$ EPIGRAMMATON A: EPIGRAMMATVM $C V$.

Epigr. 1: título: AD CATHARINAM $C V$ : AD CATH. $A \quad 1$ nostri, Catharina, libelli $V$ : nostri Catharina libelli $A C \quad 3$ nunc, Catharina, licebit $V$ : nunc Catharina licebit $A C$.

N.B: nas edições de 1748 e 1766, todos os epigramas são numerados. 


\section{AD LIBELLVM ${ }^{93}$}

Si quisquam esse nouum dicat te forte, Libelle,

Excutiatque sua protinus ille manu,

Si licet, et fas est, huic tu sic dicito, Amice

Heus Lector, ueteres nonne fuere noui?

[3]

\section{AD ANDRAEAM GOVVEANVM FRATREM}

Miraris, genio sine

Quod scribo, inuidiae sollicitus nihil.

Mi frater, genio sine,

Non est inuidiae sollicitus liber.

\section{AD AVSONIVM}

Salua tibi ueterum maneat modo regula morum,

Ludat, ais, mixtis sobria Musa iocis.

At ueterum pereat quamuis mihi regula morum,

Sordidulos fugiet pagina nostra iocos.

Namque satis fuerit caste uixisse tacentem:

Scribenti non est uita pudica satis.

${ }^{93}$ Epigr. 2: 1 forte, Libelle $C V$ : forte Libelle $A \quad 2$ manu, $A$ : manu. $C V \quad 4$ nonne $A$ : non ne $C V$.

Epigr. 3: título: GOVVEANVM AC: GOVEANVM $V \quad 2$ sollicitus E: solicitus cett. 3 sine, $A C:$ sine $V$ 4 sollicitus $A$ : solicitus $C V$.

Epigr. 4: 5 Namque $C V$ : Nanque $A$. 
In quo certarunt Fortuna, Scientia, Virtus,

Barolla exiguo conditur hoc tumulo.

At uiuos inter Fortuna, Scientia, Virtus,

Casurum nullo tempore nomen habent.

Si quaeris quid non una sint ista sepulta,

Exiguo a tumulo non potuere capi.

[6]

DE PICA IOANNIS CRVCEI PICARDI

Pica loquax Crucei studium est: Picardia namque

Dicta illi a Pica est. fallitur usque tamen.

Crediderim Pici deductum a nomine nomen:

Martia gens etenim est: Martia Picus auis.

[7]

D. M. HVBERTI

Credidit Hubertus uitam non esse secundam:

Flagitiis nullum constituitque modum.

O quam gnara mali mens, quam praesaga futuri est!

Aeterna Huberti est mors data flagitiis.

${ }^{94}$ Epigr. 5: título: IOANNIS $C V$ : IO. $A B$.

Epigr. 6: título: IOANNIS $C V$ : IO. $A B \quad 1$ namque $C V$ : nanque $A B . \quad 2$ est. fallitur $A B$ : est, fallitur $C V$.

Epigr. 7: 3 est! $C V:$ est? A. 
[8]

\section{AD AMICOS}

Versibus in nostris, quid uestra tacentur, amici, Nomina? quis posset non memor esse sui?

Non haec caussa fuit, mihi credite: nomina uerum Cum chartis nolo uestra perire meis.

[9]

D. M. LVCILLAE ${ }^{95}$

E Graeco Vetustissimo

Hoc tumulo, Lucilla, iaces enixa gemellos.

Ille patri superest: est comes ille tuus.

[10]

\section{AD ARNOLDVM}

Si mihi nil debes, quid quaeso indebita soluis,

Sponte tua factus debitor ipse meus?

Esse quid hoc dicam, nisi quod uis debitor esse,

$\mathrm{Vt}$ possis isto creditor esse modo?

${ }^{95}$ Epigr. 9: 1 gemellos. A: gemellos, $C V$. 


\section{DE BARLANDO ${ }^{96}$}

Tartareas Pluto Barlandum traxit in oras,

Obstiterint quamuis Diique Deaeque loci:

At cum flagitiis poenam non reperit ullam,

E stygiis subito iussit abire locis.

Id ueritus, ne qui terras foedauerat omnes,

Non secus ac terras Tartara pollueret.

E Gallicis Marotti

Me niue candenti petiit Catharina: putabam

Igne carere niuem: nix tamen ignis erat.

Non est uana fides, non experientia fallax:

Sensi etenim subitis corda cremata rogis.

Ergo ubi tutus ero, niuibus si conditur ardor,

Effugiamque tuas, saeue Cupido, faces?

$\mathrm{Tu}$, Catharina, potes subitas extinguere flammas,

Non glacie, aut niuibus, marmoreis uel aquis.

Sed si quae patior, poenae quoque sentiat autor:

Et nostrum flamma flagret uterque pari.

${ }^{96}$ Epigr. 11: 3 reperit $C V$ : repperit $A B$.

Epigr. 12: título: AD CATHARINAM BOFREMONTANAM E: AD CATH. BOF. cett. $A$ : una $C V$. 


\section{AD SVSANNAEVM ${ }^{97}$}

Quattuor ergo tibi Gallos placet esse Marones,

Teque illos inter quattuor enumeras.

Nae furiosus homo es, sterilis uel Gallia, quae te

Vt uates habeat quattuor, enumerat.

\section{AD SPINETIVM}

Nec gramen pastus, nec pinguem mulus auenam

Est tibi, Spineti: pinguis at ille tamen.

Quae sit caussa rogas? didicit sic uiuere paruo:

Rebus in his multum ponderis usus habet.

\section{AD MARSIVM}

Solicitas Mariam raucis crebrisque susurris,

Momentoque, senex, mille remandis Aue.

Hinc tibi promittis felicis praemia uitae,

Securusque tui fata diemque manes.

O quam te recti fallax deludit imago!

Non orare putat, labra mouere, Deus.

${ }^{97}$ Epigr. 13: 1 Quattuor $A B$ : Quatuor $C V$

Epigr. 14: 1 auenam. $A$ ': auenam, $A B C V$

Epigr. 15: 1 susurris $A$ : sussurris $C V$
2 quattuor $A B$ : quatuor $C V 4$ quattuor $A B$ : quatuor $C V$. 2 tibi, Spineti $B$ : tibi Spineti $A C V \quad 3$ caussa $E$ : caussae cett. 5 imago! $E$ : imago. $A$ imago, $C V$. 
Cum tonat, ad cellas trepido pede Vallius imas Confugit. in cellis non putat esse Deum.

\section{ICTVS AMOR}

E Graeco Theocriti

Mella Puer Veneris legeret cum forte, legenti Extremos digitos noxia fixit apis.

Exclamat, terramque ferit, flatuque dolorem

Frigidulo ignitum uincere tentat Amor.

Sic gemebundus adit Venerem, cui, respice, dixit,

Magna perexiguae uulnera, Mater, apis.

Cui Mater, tibi uis est, Nate, simillima: namque

Exigua infligis uulnera saeua manu.

Sepositas epulas media inuenisse culina,

A stupido factum Teuius esse negat.

Sepositas epulas, Teui, inuenisse culina,

Nare ualere puto, mente carere puto.

${ }^{98}$ Epigr. 16: 2 Confugit. $A B$ : Confugit, $C V 7$ namque $E$ : nanque cett. Epigr. 18: 3 culina $A B V$ : colina $C$. 
Quod patrem Stygium, Barene, dicis

Neptunum, notulis tuisque mandas,

Dictum crediderim esse Tulliane.

[20]

AD ZEBEDAEVM ${ }^{99}$

Pernicies uini, patri caper hostia Baccho

Concidit, ante aras eluitura nefas.

Bacchi ergo, Zebedaee, aras mactaberis ante:

Namque caper uino mitior esse solet.

[21]

DE CATELLO, CVI NOMEN PARIS

Qui tantae uoluit tibi urbis esse

Nomen, deliciae Catelle nostrae,

Virtutem ille tuam et sagacitatem,

Tanto nomine uisus est uocasse.

${ }^{99}$ Epigr. 20: 1 Baccho $E$ : Baccho. $A$ Bacco. $C V \quad 2$ Concidit $C V$ : Concedit $A 4$ Namque $E$ : Nanque cett. 


\section{DE RIBALDO ${ }^{100}$}

Est canis huic nomen Ribaldus, amorque iocique

Cura, labor, studium, deliciaeque meae.

Ore canis patulo, maculoso tegmine, collo

Prominulo ac gracili, corpore et aure breui:

A pede lunato poples subducitur olli

Inferior triplici barba notata pilo est:

Renibus e latis tenuis se cauda profundit.

Nomen deme, uides in cane turpe nihil.

\section{AD CATHARINAM BOFREMONTANAM}

Sint tibi, sint quamuis, nullae uirtutibus, alto

Iudicio, antiqua nobilitate pares,

Nil mirum: tibi quae summi tribuere Deorum

Quis, Catharina, potest, aut petere, aut capere?

${ }^{100}$ Epigr. 22: 2 Cura, labor, studium, deliciaeque meae: $C V$ : Cura, labor, studium, delitiaeque meae. $A$ ' Deliciae, domini cura, laborque sui: $A$.

Epigr. 23: título: AD CATHARINAM BOFREMONTANAM $C V$ : AD CATH. BOF. $A 3$ tibi $A C$ : ubi $V$. 


\section{AD MAXIMVM ${ }^{101}$}

Dente laboranti ac medicamina certa petenti,

Vt biberes uetulae consuluere tibi.

Maxime, consilium noceat ne forte timendum est:

Namque uoles redeat saepius iste dolor.

\section{AD IOANNEM BORDAEVM}

Nostra tuis uinci fateor munuscula donis:

Nec, qua parte, roges: sit satis esse mea.

At tua, quod tua sunt: quid enim plus dicere possum?

Abs te uicta tamen, uincere nemo neget.

Nos igitur quanto superes, Bordaee, nec ipse

Quamuis multa potes, dicere forte queas.

\footnotetext{
${ }^{101}$ Epigr. 24: 4 Namque E: Nanque cett.
}

Epigr. 25: título: IOANNEM $C V$ : IOAN. $A$. 
Me nudam Paris, et nudam me uidit Adonis,

Ille meus iudex, et meus alter amor.

Verum ubi me Rhodius nudam uidisset Apelles?

Fabula. uidisset scilicet ille Deam.

Sic tamen ad uiuum qui me depinxit, oportet

Nudatam Venerem uiderit ille quoque.

Cum tribus Ausoniae certas, Macrine, poetis:

Idque lyra, salibus, flebilibusque modis.

Nec frustra multa egregie conaris: at unus

Vix queat Alcides exsuperare duos.

${ }^{102}$ Epigr. 26: título: Antonii $V$ : Ant. A Antonius $C \quad 4$ Fabula. $A$ : Fabula, $C V$. Epigr. 27: 4 exsuperare $E$ : exuperare cett. 


\section{AD IOANNEM CRVCEVM ${ }^{103}$}

Argutis Epigrammatum libellis

Toto notus in orbe Martialis

Quaeris qui fuerit, negasque notum,

Argutis licet usque et usque chartis,

Extremis hominem fuisse terris.

Mendaci arguis, et tenes aperti:

Hispanum tamen esse schema nescis.

${ }^{103}$ Epigr. 28: título: IOANNEM $C V$ : IOAN. $A \quad 3$ notum, $A C$ : notum $V$. 
DE REGE ET NAVTA ${ }^{104}$

\section{Per freta cum ueheret Regem diuersa, patremque}

Submersum tumidis Nauita fleret aquis,

Rex illi, quis te tantus furor egit, inepte,

Ausus ut infido sis dare uela mari?

Cui Vector, molli quid te, Rex Optime, lecto

Credis, ubi patrem scis periisse tuum?

${ }^{104}$ Epigr. 29: 1 diuersa, patremque $A C$ : diuersa patremque $V$.

A versão editada e exposta acima corresponde à que consta na errata da edição de 1539, bem como nas edições de 1748 e 1766. A versão original do poema (que também foi utilizada na antologia de 1555) é a seguinte:

Exiguo Regem ducebat Nauta phasello,

Dum fremerent raucum uentus et unda ferox.

Rex Nautam aggreditur, patriamque patremque roganti,

Ostendit Vector non procul inde casas.

Et pater, inquit, erat parui quoque Nauta phaselli,

His quondam in mediis contumulatus aquis.

Cui Rex, quae ergo animo tibi tanta audacia cessit,

Hoc nihil ut dubites solicitare fretum?

Cui Vector, molli quid te committere lecto

Non dubitas, periit quo pater ante tuus? 


\section{AD MEDIANVM}

Rectum Euangelii cursum, Mediane, retardas,

Lucentemque tegis lampada sub modio.

Quid caussae est? faciens contra, ne forte noteris.

Sic odisse solet fur, Mediane, diem.

DE ASELLO ${ }^{105}$

Ad cenam sponsus ueterem inuitauit Asellum,

Cui nullus toto corpore sanguis erat.

Hic grandem pro se natum delegat, opusque

Quid factu et quali cum ratione docet.

Aulam ipsam quadam cum maiestate subintra:

Saepe recusato membra repone loco.

Si comedant, saltent, cantent, haec omnia, Nate,

Fac, ut honestatis non uideare rudis.

Cui Natus, futuant si forte, quid? id mihi manda,

Atque istic subito, dixit Asellus, ero.

${ }^{105}$ Epigr. 31: 1 cenam $E$ : coenam cett. 4 ratione, $A$ : ratione; $C V$. 


\section{E GALLICIS IACOBI BELNAEI}

Forte locum horroris plenum uariique timoris

Et Mors et penna praepete uenit Amor.

Dum trepidant animis, ignita Cupidinis arma

Mors capit, et Mortis frigida tela Puer.

Hinc enata lues nostros irrepsit in annos:

Hinc amat ipse senex, hinc perit omnis amans.

[33]

DE MONACHO ${ }^{106}$

Discite, ait populo Monachus, cum uerba tonaret,

Quam doceret, coepit ante facere Deus.

Qui, stupidus quamuis, lapsum se turpiter esse

Vt uidet, errorem quo tueatur, ait:

Si breuia extendo, si longa coerceo uerba,

Nec retinet tempus syllaba quaeque suum,

Nil mirum est. annis fertur fecisse triginta

Patris iussa, rudes instituisse tribus.

\footnotetext{
${ }^{106}$ Epigr. 33: 4 tueatur, ait $B$ : tueatur ait $A C V \quad 7$ est. annis $A$ : est, annis $B C V$.
} 
DE CAROLO ET CHRISTOPHORO CANDALLEIS FRATRIBVS ${ }^{107}$

Par uirtus, par nobilitas, par nobile fratrum

Ornat, commendat par quoque utrumque decor.

Par etiam, ast annis multo prudentia maior:

Caeca quibus uoluit non minor esse Dea.

Haec paria ex omni si non data parte fuissent,

Quid maius poterat Iuppiter ipse dare?

DE PVELLA CASTA ${ }^{108}$

Oscula cum uellet Furius libare Puellae,

Aduersam Furii percutit illa genam.

Dixit et, I, manui crepitantia basia fige:

Namque eadem penitus sunt manus, osque, caro.

\footnotetext{
${ }^{107}$ Epigr. 34: título: CAROLO ET V: CAROLO, ET $A B C \quad 2$ utrumque $C V$ : utrunque $A B$.

${ }^{108}$ Epigr. 35: 2 illa $A B C$ : illam $V \quad 4$ Namque $E$ : Nanque cett. osque, caro $A B$ : osque caro $C V$.
} 


\section{AD CATHARINAM BOFREMONTANAM ${ }^{109}$}

Si te, flauenteisque comas, oculumque nitentem,

Labraque purpureis uiuidiora rosis,

Si decus hoc rarum, diuinum si oris honorem

(Ne quid ego uidear dicere forte nimis)

Incessumque grauem, qualem iurem esse Dearum,

$\mathrm{Si}$, quae est uirtutum gratia blanda comes,

$\mathrm{Si}$, quae est nobilitas ab auis proauisque relicta,

Quae potuit meritis esse profecta tuis,

Miror amoque, meo quae gratia debita amori est?

Fac siquidem nolim, cogar amare tamen.

\section{[37]}

\section{AD STEPHANVM DOLETVM ${ }^{110}$}

Quid te non laudem, credo, Dolete, requiris,

Id me tu melius facis.

${ }^{109}$ Epigr. 36: título: AD CATHARINAM BOFREMONTANAM $C V$ : AD CATH. BOF. $A 7$ quae $A C$ : quase $V$ ab auis $V$ : abauis $A C \quad 9$ amoque, meo $A$ : amoque meo $C V$.

${ }^{110}$ Epigr. 37: título: AD STEPHANVM DOLETVM E: AD STEPH. DOLETVM cett. 1 credo Dolete requiris $A C V$ : credo, Dolete, requiris $B$. 


\section{DE MONACHO ${ }^{111}$}

Deprensum nemore in medio iussere latrones,

De Christi Monachum religione loqui.

Qui dicto citius, neque enim fas dicere contra,

Paret, et hoc fatus dicitur esse modo:

Acta manus Iuuenum terrae pelagique periclis,

Haec haec, quam sequeris, ducit ad astra uia.

Namque uagabatur terraque marique, nec uno

Narratur Christus consenuisse loco.

Tu quoque nunc illuc, nunc huc absque ordine curris,

Horaque non uno te uidet una loco.

Non putrem curuo terram uertebat aratro,

Nec solitus terrae credere semen erat:

Viuebat tamen, et uitae nil defuit umquam:

Hac quoque uos estis commoditate pares.

Quid plura? alta fuit tandem ad subsellia tractus,

Damnatusque: eadem uos quoque fata manent.

Ille cruci affixus uitam cum sanguine fudit:

Non eritis, credo, uos meliore loco.

Vmbrarum ille domos caecaeque cubilia noctis

Visit, et est uobis ista terenda uia.

Ille tamen subito caelestia regna reuisit:

Non dabitur uobis inde referre gradum.

${ }^{111}$ Epigr. 38: 2 religione $C V$ : relligione $A B 7$ Namque $E$ : Nanque cett.

marique, nec $\mathrm{AB}$ : marique nec $C V 13$ umquam $E$ : unquam cett. 21 caelestia $E$ : coelestia cett. 
[39]

AD ANDRAEAM GOVVEANVM FRATREM ${ }^{112}$

Accepi, frater, leporem: tibi ponitur. an non

Id uere est leporem perdere, et accipere?

[40]

\section{AD CATHARINAM BOFREMONTANAM}

Parce mihi, si quod mirari debeo, miror:

Amoque, officii oblitus mei.

Et facies: siquidem nulli fas dicere sisne

Diuinior, an humanior.

AD NVGIVENDVLVM ${ }^{113}$

Si tanti pergas nihili diuendere nugas,

Hoc studium cunctis, hic labor unus erit.

Sic ars, atque artis uilescet protinus usus.

Ergo tibi melius, uende minoris, erit.

${ }^{112}$ Epigr. 39: título: GOVVEANVM ABC: GOVEANVM $V 1$ Accepi, frater, leporem $B$ : Accepi frater leporem $A C V$ ponitur. $A B$ : ponitur, $C V$.

Epigr. 40: título: AD CATHARINAM BOFREMONTANAM $C V$ : AD CATH. BOF. $A 1$ miror $A V$ : mirot $C 2$ Amoque, officii $A$ : Amoque officii $C V \quad 3$ sisne $A$ : sis ne $C V$.

${ }^{113}$ Epigr. 41: título: NVGIVENDVLVM $A V$ : NOGIVENDVLVM $C$. 


\section{AD PRAGMONEM ${ }^{114}$}

Destruis, aedificas, rursum, prorsum omnia uersas:

Inque suo, Pragmon, nil sinis esse loco.

Vis, credo, dicant nil te fecisse minores:

Omnia, sed dicent, qui faciebat, erat.

\section{DE VETVLA}

Et tractare manu Thomam, et uectoris aselli

Vellere certabat credula turba pilos.

Hic Anus in Thomae canos rarumque capillum

Inuolat, ac rapido uellicat ungue Senem.

Infremuit Thomas: Anus obstupefacta, quid, inquit,

Nonne pilos Asini uellere cuique datum est?

\section{AD IACOBVM ALENIVM}

Quae nostri numquam meruere, Iacobe, labores,

Quae nec ego officiis promeruisse puto,

Das mihi. peccatum est. uerum tu dicere possis,

Quod mihi plus satis est, non satis esse tibi.

\footnotetext{
${ }^{114}$ Epigr. 42: 1 aedificas, rursum $A C V$ : aedificas rursum $B \quad 2$ suo, Pragmon, nil $V$ : suo Pragmon nil $A B C \quad$ sinis $A B C$ : finis $V$.

Epigr. 43: 6 Nonne $A$ : Non ne $C V$.

Epigr. 44: título: IACOBVM E: IACOB. cett. 1 numquam $E$ : nunquam cett. meruere, Iacobe, labores, $B$ : meruere Iacobe labores, $A C$ meruere Iacobe labores $V \quad 3$ mihi. peccatum est. $A$ : mihi. peccatum est, $B$ mihi, peccatum est, $C V$.
} 


\section{DE PIMPINO ${ }^{115}$}

Immensum trabe sulcaret dum Pimpinus aequor,

En subito aequoreas concitat Eurus aquas.

Quemque suus casus, sua quemque pericula terrent,

Et graue cuique, auidis piscibus esse cibo.

Pimpinus hic, uobis mors omnibus, inquit, amici,

At mihi sunt gelidae caussa timoris aquae.

Nam mare si faceret diuina potentia uinum,

Hic uellem tumulum corporis esse mei.

[46]

\section{AD MAXIMVM}

Importunus ego dicor tibi, Maxime, semper,

A me cum petitur caseus iste tuus.

Quid tibi uis? uel caseolum da, Maxime, totum,

Vel non des uitio, quod facis ipse, mihi.

${ }^{115}$ Epigr. 45: 3 Quemque ... quemque $C V$ : Quenque ... quenque $A B \quad 6$ caussa $A B$ : causa $C V$. Epigr. 46: 1 Importunus $A V$ : Importunos $C$. 


\section{AD ALPHASIANVM ${ }^{116}$}

Rhethoricam praefers artem, Alphasiane, culinae:

Pene e sordidulis ut uideare coquis.

Esse quid id dicam, nisi quod uis maior haberi

Orator, quam sis, Alphasiane, coquus?

[48]

AD VVLTEIVM

Inscriptionum, non Epigrammatum libros,

Tuarum ineptiarum Amazonidem uocas.

Erras inepte, Scriptionum sunt libri.

\section{AD CATHARINAM BOFREMONTANAM}

Tum dabo pro xeniis tibi me, Catharina, lubenter,

Reddideris postquam me, Catharina, mihi.

${ }^{116}$ Epigr. 47: 1 Rhetoricam $A B$ : Rethoricae $C V$ artem, Alphasiane, culinae $B$ : artem Alphasiane culinae $A C V \quad 4$ sis, Alphasiane, coquus $B$ : sis Alphasiane coquus $A C V$.

Epigr. 49: título: AD CATHARINAM BOFREMONTANAM $C V$ : AD CATH. BOF. $A 1$ me, Catharina, lubenter $B$ : me Catharina lubenter $A C V \quad 2$ me, Catharina, mihi $B$ : me Catharina mihi $A C V$. 
[50]

AD IOANNEM CRVCEVM ${ }^{117}$

Saepe mihi dicis, res magna est esse patronum:

Esse nihil, dico saepius ipse tibi.

Nam quid id est, quod si in terras mens sana rediret,

In terris nullum posset habere locum?

DE FABRO

Quercus erat sterilis medio latissima campo,

Quercus Olympiaci maxima cura Iouis:

Hanc Faber esse Deum uoluit: fecitque Priapum,

Inque sacra proprium sede locauit opus.

Turba nouo sua uota Deo cum ferret, et una

Funderet assuetas cum Faber ipse preces,

En alta de sede Deus ruit, unius ictu

Horrendo Fabri comminuitque caput.

Qui uitam effundens, uix interfatus amicos

Sic interruptis dicitur esse sonis:

Discite ab exemplo noua cudere Numina: Quercus

Deterior facta est, est ubi facta Deus. 


\section{AD IOANNEM PODIANVM ${ }^{118}$}

Fers maiora tuo, Podianule, corpore dona.

Quis te oneri tanto crederet esse parem?

Quis, nisi qui mentem multo tibi nouerit esse

Corpore maiorem, muneribusque tuis?

\section{AD CATHARINAM BOFREMONTANAM}

Saepius ardenti per laudes ire tuorum,

Perque tuas, titubat si, Catharina, manus,

Culpa tua est: siqua esse potest in Numine culpa:

Ingenium uati surripis omne tuo.

\section{M. GABRIELIS TARRAGAE MEDICI}

Viderat, et poterat uenientem euadere mortem

Tarraga: at certo maluit ille mori.

Maluit ille mori, melius quo uiuere posset

In superis. Medicum nil Medicina iuuat?

${ }^{118}$ Epigr. 52: título: IOANNEM $C V$ : IO. $A$.

Epigr. 53: título: AD CATHARINAM BOFREMONTANAM $C V$ : AD CATH. BOF. $A$. 
[55]

AD STEPHANVM DOLETVM ${ }^{119}$

Si Ciceronis habent animam tua carmina, certe

Habere tu potes quoque.

[56]

\section{AD CATHARINAM BOFREMONTANAM}

Te quaeso primam specie uirtutis in omni

Quis dicat, cum sit nulla secunda tibi?

[57]

\section{AD LECTOREM SVI EVAGORAE}

Isocratis ueneres, numeros ac lumina possum,

Lector, si minus assequi,

Tanta tamen uirtus, melius fortasse uideri,

Quam nostro uitio, nequit.

${ }^{119}$ Epigr. 55: título: STEPHANVM E: STEPH. cett.

Epigr. 56: título: AD CATHARINAM BOFREMONTANAM $C V$ : AD CATH. BOF. $A B$. 


\section{AD FRANCISCVM FRANCORVM REGEM ${ }^{120}$}

E Gallicis Mellini Sangelasii

Si melior uirtus, si gratia gratior esse,

Sorsque uelit fieri prospera, prosperior,

Consultum mage consilium, perfectioque ipsa

Perfici, et ad numeros addere multa suos,

Abs te debebunt, Rex, impetrare reponi

Se titulos inter ut patiare tuos:

Vtque bonus, gratus, felix, dici ore nepotum

Prudens, perfectus, qualis es ipse, uelis.

\section{AD ZEBEDAEVM}

Nec uoces hominum, nec te decreta Senatus,

Vt barbam ponas ulla mouere queunt.

Nolo uirum barba quaerit qui nobilis esse:

Hunc uolo qui barbam nobilitare potest.

${ }^{120}$ Epigr. 58: título: AD FRANCISCVM FRANCORVM REGEM E Gallicis Mellani Sangelasii $E$ : AD FRANC. FRANCO. REGEM E Gallicis Mel. Sangelasii $A B$ AD FRANC. FRANCORVM REGEM $E$ Gallicis Mel. Sangelasii $C V \quad 7$ bonus, gratus, felix $A C V$ : bonus gratus, foelix $B$. 


\section{AD BORBONIVM ${ }^{121}$}

Si nomen tibi uis sacrum poetae,

Borboni, leuibus parare nugis,

Te nos rusticula ac profana turba,

Qui nugas facimus minoris asse,

Te nos unius aestimemus assis?

\section{AD ARCHIPOETAM}

Audieris magnum postquam scripsisse Maronem,

Vix eris ipse tibi semipoeta malus.

Petrarchae uoluens diuina poemata Phoebus,

Haec est Laurus, ait: sit modo Laura licet.

Dixit, et insontis letali uulnere costas

Transadigit dicens, temnito Laura Deum.

Laura animam effundens, Phoebum dileximus, inquit:

Peccatumque mihi sit placuisse Deum.

\footnotetext{
${ }^{121}$ Epigr. 60: 2 Borboni, leuibus $V$ : Borboni leuibus $A C$.
}

Epigr. 62: 1 Phoebus A: Phaebus $C V$. 
RESPONSVM AMORIS

E Gallicis Albenatii

Indutus doctoris Amor uultumque, togamque,

Tractabat medio maxima quaeque foro.

Huic ego, per Venerem dic, cur dolor adstat amori?

Ille mihi, solus mors, ait, esset amor.

AD LECTOREM

Sunt mala, sunt quaedam peiora, et pessima plura.

Arguit autorem pagina nostra suum.

\section{FINIS LIBRI PRIORIS ${ }^{122}$}

${ }^{122}$ FINIS LIBRI PRIORIS A: LIBRI PRIMI FINIS $C V$. 


\section{EPIGRAMMATON $^{123}$}

\section{LIBER SECVNDVS}

[1]

\section{AD CATHARINAM BOFREMONTANAM}

$\mathrm{Si}$, Catharina, tuum nomen mea pagina sumpsit, Inque patrocinium se dedit ipsa tuum,

Nil mirum: quae digna fuit fortasse perire,

Vindice se tali uiuere posse putat.

[2]

\section{AD LECTOREM}

Ineptiarum uolue quaeso nostrarum,

Lector, secundum quem tibi affero librum.

Addamque tertium, tibi id modo sit gratum.

Ineptiarum namque nos penes, Lector,

Et tertio et quarto sat est etiam libro.

${ }^{123}$ EPIGRAMMATON A: EPIGRAMMATVM $C V$.

Epigr. 1: título: AD CATHARINAM BOFREMONTANAM $C V$ : AD CATH. BOF. A.

Epigr. 2: 2 affero $E$ : adfero cett. 4 namque $E$ : nanque cett. 
[3]

DE VIRGINIS PALLORE ${ }^{124}$

E Gallicis Antonii Alacris

Castra locarat Amor securo in corde Puellae:

Et nimis, in tenero pectore, durus erat.

Quodque magis doleas, uitam bibit artubus omnem

Efferus, heu, nimium, sanguineusque Puer.

Hîc cor, ubi affectas uires persensit, ab ore

Purpurei acciuit sanguinis auxilium.

[4]

\section{FALSVS CVPIDO}

Barbara uelato Gelasina ocurrit Amori:

Occepitque Puer dicere, Mater aue.

Illa nihil contra. at subito uelamine dempto

Ex oculis, Pueri permeat ora pudor.

Ah ne te lapsus pudeat, uelate Cupido:

Hoc etiam errarunt lumina aperta modo.

${ }^{124}$ Epigr. 3: 2 pectore, durus $A C$ : pectore durus $V$.

Epigr. 4: 3 contra. $A$ : contra, $C V \quad 5$ pudeat, uelate $V$ : pudeat uelate $A C$. 
Dignum opus a sera quod posteritate legatur, Absoluit numeris Valleriola suis.

Perlege opus tantum, auctorem miraberis: ipsum

Noueris auctorem, pluris emetur opus.

Frustra ergo accedat mea commendatio: laudat

Ipsum opus auctorem: laudat et auctor opus.

\section{[6]}

\section{M. MONTANI IVRISPERITI}

Montanus trepidos media de morte trahebat,

Viribus eloquii consiliique reos.

Mors regnum, lucrumque Charon, duraeque Sorores

Clamabant uires succubuisse suas.

Nec mora, Montanum rapiunt sine legibus ullis.

Ah, non sic fatis abstulit ille reos.

[7]

\section{AD IACOBVM BELNAEVM}

Cum uates numeras, quos secula nostra tulere,

Me uatum in numerum iure, Iacobe, refers.

At uates si uis aequata pendere lance,

Non ero, crede mihi, ponderis huius ego.

${ }^{125}$ Epigr. 5: título: FRANCISCI E: FRAN. cett. $\quad 3$ auctorem E: autorem cett. $\quad 4$ auctorem $E$ : autorem cett. 6 auctorem ... auctor $E$ : autorem ... autor $A C V$ authorem ... author $B$.

Epigr. 6: 3 Sorores $A B C$ : Sorores, $V$. 
[8]

\section{AD MELLINVM SANGELASIVM ${ }^{126}$}

Nostros, Sangelasi, tibi libellos,

Libellos breuitate singulari

Commendo, exiguis licet, uidebis

Conclusum genus omne ineptiarum.

[9]

\section{AD LECTOREM}

Pauca damus, fateor, sed inepta epigrammata, Lector:

Ergo multa nimis dicere iure potes.

[10]

\section{AD DOLETVM}

Si salsum est nihil in tuis libellis,

Dolete, hac poteris uacare culpa:

Qui sudaueris usque et usque totus,

Vt scriptor fieres subinde salsus,

Tuum os hoc rigidum, minax, seuerum,

Os dirum, os tetricum, os Catonianum,

Romani fugiunt sales iocique.

\footnotetext{
${ }^{126}$ Epigr. 8: 1 Nostros, Sangelasi, $C V$ : Nostros Sangelasi $A$.
}

Epigr. 10: 6 Catonianum, $A C V$ : Catonianum $B$. 
D. M. CIRETTI

Ciretti similem si Mors superesse putasset

Iniuriarum uindicem,

Non patriae, uxori, natis, non legibus ipsis,

Fecisset hanc iniuriam.

E GALLICIS MAROTTI ${ }^{127}$

Quaerit opem Corpus medicam, Mens omnia contra:

Carceribusque atris ire soluta cupit.

Corpus humum, cognata leuis Mens suspicit astra.

Dii, quam terrificum Mensque Caroque fremunt?

Mene ita, Corpus ait, tristi succumbere morbo?

Mens contra, inuisas me trahere usque moras?

I, Caro ait, meliora peto: cui Spiritus, errat,

Inquit, uterque: Dei stemus in arbitrio.

${ }^{127}$ Epigr. 12: 5 Mene $A B$ : Me ne $C V$. 
Parce mei quaeso Goueani temnere Musam,

Petrarcha nimium, Laura, superba tuo.

Crede mihi, scribit quo plura Petrarcha disertus,

Hoc eius distat mens ab amore magis.

Cui non suffuratur Amor de corpore sensus,

Iudicium? memorem quem sinit esse sui?

Ergo meum non ingenio cessisse Petrarchae

Credideris Vatem, plus sed amasse tuo.

\section{AD IOANNEM LVSITANIAE REGEM}

Cum tibi nec uires, nec opes in proelia desint,

Fortuna arbitrio stetque cadatque tuo,

Quid non finitimos flamma ferroque lacessis?

Quid non iniustum ius tibi ubique facis?

Haec tua diuina est, ac plane regia uirtus,

Posse nocere quidem, nolle nocere tamen.

${ }^{128}$ Epigr. 13: 1 mei quaeso $A C$ : mei, quaeso, $V \quad 2$ Petrarcha $A C$ : Petrarcha, $V \quad 5$ corpore $V$ : corpore, $A C$.

Epigr. 14: título: IOANNEM $C$ : IOAN. $A B$ IOANNEM, $V \quad 1$ proelia $E$ : praelia cett. 2 stetque $A B C$ : stetque, $V$. 


\section{AD IACOBVM BELNAEVM ${ }^{129}$}

Dissimulanda mihi fuerat mea patria: uerum

Carminibus patriam uiuere nolo meis.

Adde quod illius tanta est lux, gloria tanta,

Lumine ut in tenebris luceat ipsa suo.

[16]

\section{AD ARCHIPOETAM}

De numero uatum, uates detraxeris omnes,

Hoc subito fies Archipoeta modo.

\section{DEARVM INVIDIA}

Videre, et Catharina tibi inuidere puellae

Tres diuae, Iuno, Pallas et alma Venus.

Sic indignantes secum, dirumque frementes,

Ante Iouem posito procubuere genu.

Hic Iuno, ante alias, medio interfata dolore est,

Singultu tremulos excutiente sonos.

Iuno impertit opes, et Iuno impertit honores?

Fabula. ab humanis sumere Iuno potest.

${ }^{129}$ Epigr. 15: título: IACOBVM $E$ : IAC. cett. BELNAEVM ACV: BELNEVM $B$. Epigr. 16: 1 uatum, $A B C$ : uatum $V$.

Epigr. 17: 2 Pallas $A C V$ : Pallas, $B \quad 8$ Fabula. $A B$ : Fabula, $C V$. 
Tum Venus, o Genitor, Diuas quae uicit in Ida, ${ }^{130}$

Humana ut forma sit modo uicta Venus?

At Pallas, quid me cerebro genuisse necesse,

Pallada si possunt foemina uirque dare?

Iuppiter hic, tales aliam genuisse parentes

Non potuere: tamen non genuere Deam.

[18]

\section{AD BORBONIVM}

Nugarum uoco gratia poetam

Quo te saepius, hoc magis magisque,

Borboni, dubito leues ne possint

Nugae reddere serium poetam.

\section{AD LECTOREM}

Cresce meo dico, Lector studiose, libello.

At contra ille mihi, non sapis hercle pater.

Cum rogito caussam, ridens sic ille, libellus

Si placeo, speras posse placere librum?

\footnotetext{
${ }^{130}$ Epigr. 17: 9 Genitor, $V$ : Genitor $A B C \quad 11$ necesse, $A B C$ : necesse $V \quad 12 \quad$ Pallada $A B C$ :
} Pallada, $V$. 


\section{AD MARONEM ${ }^{131}$}

Ne mirere, Maro, cur Archipoeta uocetur

Nescio quis: uera est cognita caussa mihi.

Quantum a postremis distas, Maro docte, poetis,

Tantum distat ab his Archipoeta meus.

Nam quo postremis prior es, Maro docte, poetis,

Posterior tanto est Archipoeta meus.

Si Laurae, Catharina, par haberis,

Quam tantam eximius poeta fecit,

Hoc Laura potes esse maior ipsa,

Quo me maior erat Petrarcha uates.

\section{AD POSTHVMVM}

Contentus esse filiabus, Posthume,

Auctus duabus, sorte iam potes tua.

Nam si neque dimidium petebas unius,

Plus quam petebas accepisti, Posthume.

${ }^{131}$ Epigr. 20: 1 mirere, Maro $B$ : mirere Maro $A C V \quad 3$ distas, Maro docte, $B V$ : distas Maro docte $A C$. Epigr. 21: título: AD CATHARINAM BOFREMONTANAM $C V$ : AD CATH. BOF. $A$. 


\section{AD STEPHANVM DOLETVM ${ }^{132}$}

Pythagorae, Dolete, placet si dogma renati,

Non mirum est, animam si Ciceronis habes.

At tantam molem, et tantos diffusa per artus,

Virtutem certe perdidit illa suam.

\section{M. SIBYLLAE BARTIAE}

Cum Pater ipse hominum coelis inferre Sibyllae

Et mentem, et mentis terrea claustra parat,

En tellus natae collo dans brachia circum,

Patri animum, matri reddito corpus, ait.

Nata piae iustas lachrymas miserata parentis,

Liquit materno corpus inane sinu.

O sacri Vates, dilectaque pectora Phoebo,

Gratis nemo putet scommata nostra dari.

Nec mihi larga manus, nec copia magna. quid ergo?

Ad faenus, Vates, scommata nostra damus.

\footnotetext{
${ }^{132}$ Epigr. 23: título: STEPHANVM E: STEPH. cett. 1 Pythagorae, Dolete, $B V$ : Pythagorae Dolete $A C$. Epigr. 24: título: SIBYLLAE $A C V$ : SYBILLAE $B \quad 1$ Sibyllae $A C V$ : Sibillae $B$. 
Tanta tua, Arleri, grauitas, prudentia tanta,

Quanta potest homini caelitus esse data.

Tanta est cognitio uariarum condita rerum,

Quantam ferre dies longa laborque solent.

Quae faciunt, scelus ut credam, quodcumque probasti,

Seu damnare alium, siue probare minus.

At quando, Arleri, tibi somnia nostra probantur,

Numquid iudicio falleris ipse tuo?

An potius (nec enim tantum scelus excidet ore)

Verum iudicium, lingua modesta tua est?

[27]

AD IANVM HABERTVM

Quae tu pauca putas Epigrammata, Iane, putarim,

Si bona, multa satis, si mala, multa nimis.

${ }^{133}$ Epigr. 26: título: ANTONIVM E: ANTO. A ANTON. $C V 1$ tua, Arleri, $V$ : tua Arleri $A C \quad 2$

caelitus $E$ : coelitus cett. 5 quodcumque $E$ : quodcunque cett.

7 quando, Arleri, E: quando, Arleri $C V$ quando Arleri $A$. 8 Numquid $E$ : Nunquid cett.

Epigr. 27: 1 Epigrammata, $B C V$ : Epigrammata $A \quad 2$ satis, $A B C$ : satis: $V$. 


\section{AD CATHARINAM BOFREMONTANAM ${ }^{134}$}

Vincis me ingenio, lepore, forma,

Vincis nobilitate, uincis omni

Virtutum genere omnium optimarum:

Vincis, non nego, nec negare possum:

Ignorant sed amor meus fidesque

Vinci: et sola mouent rebellionem.

\section{DE LAVRENTIO VALLENSI}

Ex iuramento Vallensis utramque Mineruam

Emendaturus, si potuisset, erat.

Quid faciat? pugnet Latiae Graecaeque Mineruae.

At bene non potuit: debuit ergo male.

\section{M. IOANNIS ALBERTI ${ }^{135}$}

Ne tumulum Alberti exiguum mirere, Viator:

Nam quo potuit cumque obtegi

Albertus tumulo, doctae potuere Sorores,

Et Gratiae, et Pietas tegi.

${ }^{134}$ Epigr. 28: título: AD CATHARINAM BOFREMONTANAM $C V$ : AD CATH. BOF. $A \quad 5$ meus fidesque $V$ : meus, fidesque, $A C$.

Epigr. 29: 1 utramque $E$ : utranque $c e t t$.

${ }^{135}$ Epigr. 30: IOANNIS E: IOAN. cett. 1 mirere, $B$ : mirere $A C V \quad 2$ cumque $A C V$ : cunque $B$. 


\section{AD ANOSIVM ${ }^{136}$}

Saepe rogare soles, de te quid sentio: laudo

Virtutis dotes, ingeniique tui.

Ventosum caput est, mens impia, lingua profana,

Exertae atque agiles ad scelus omne manus.

Immensa est gula, et horrentis uia spurca Barathri,

Culo sordidior foetidiorque tuo.

Crura pedesque, doli, stupri, furtique columnae.

An nunc, quid de te sentio, scire potes?

\section{AD GILIBERTVM}

Vis, Giliberte, mihi donis animoque placere:

Visque ut ego seui, sic ego ut arua metam.

Verum ut displiceas timeo, Giliberte: placere

Qui uirtute mihi non satis esse putas.

${ }^{136}$ Epigr. 31: 2 tui. $A C$ : tui? $V$.

Epigr. 32: v. 1: Vis, Giliberte $C V$ : Vis Giliberte $A$ AC. 


\section{AD CATHARINAM BOFREMONTANAM ${ }^{137}$}

Te primum ut uidi magnorum munere Diuum,

Quaerebas nomen dissimulare tuum.

Ast Amor auriculam, subito miseratus amantem,

Vellit, et admonuit nominis ipse tui.

Haesi ecquidem, obtutum longum defixus in unum:

Deceptus tamquam, sustinuique fidem.

Quid dubitas? ait ille: Deo crede, impie, crede.

Huic ego contra, hominis nomen habere Deam?

\section{DE BASSA}

Sacrificum cur Bassa preces pro Coniugis umbra

Non emeret, caussam saepe rogata fuit.

Bassa ait, his precibus Coniunx non indiget ullis:

Seu penitus felix, siue sit usque miser.

Quod si paulisper rapido purgetur in igne,

Quid? faciam ut preculis exeat inde meis,

Inde, ubi sudando tandem exudauerit imis

Visceribus Gallae dira uenena luis?

${ }^{137}$ Epigr. 33: título: AD CATHARINAM BOFREMONTANAM $C V$ : AD CATH. BOF. $A$ 


\section{AD SVSANNAEVM ${ }^{138}$}

Ska/zon, quod mihi sic, Poeta, laudas, Non seruat numeros Iambicorum.

Skazo/ntwn neque lege fertur. ergo, $\mathrm{Ska} / \mathrm{zon}$ scribere cum semel putabas, Ska/zon claudo abit haud semel Poetae.

\section{AD ZEBEDAEVM}

Nocte domum, Zebedaee, refers quod in urbe uagatur:

Visque dari nugis optima uina tuis.

Iam iam deficient portanteis uina ministros:

Nam si multa refers, plus, Zebedaee, bibis.

\section{AD LECTOREM ORATIONIS ILLIVS PRO CTESIPHONTE}

Crimina, quae facto temerarii admisimus uno,

Exemplo ut caueas, accipe posteritas.

Eloquii fulmen gelido restinximus amne:

Misimus in putres Caecuba uina cados.

Quodque putes grauius, fuerat qui uictor Athenis,

Caussa hodie uitio decidit ille meo.

${ }^{138}$ Epigr. 35: este epigrama do volume original de 1539 não consta das edições posteriores $(1555,1748$, 1766).

Epigr. 36: 1 domum, Zebedaee, $C V$ : domum Zebedaee $A$.

Epigr. 37: título: PRO CTESIPHONTE $A V$ : PROCTESIPHONTE $C$. 
[38]

D. M. FRANCISCAE PERVSIAE

Ad Venerem

Quid, quod in aetatis Francisca Perusia flore

Erepta est, flesti tuque, Puerque tuus?

Quid flesti, siquidem poterat nihil addere formae,

Virtuti, ingenio Virginis, ipsa Dies?

[39]

\section{AD CATHARINAM BOFREMONTANAM ${ }^{139}$}

Viuere si nostri possint, Catharina, labores,

Et tandem a sera posteritate legi,

Gratia multa tibi: siquidem meliore Camena

Dignior, in nostro es carmine passa legi:

Vt magno felix debet quod Laura Petrarchae,

Debeat id tandem pagina nostra tibi.

${ }^{139}$ Epigr. 39: título: AD CATHARINAM BOFREMONTANAM CV: AD CATH. BOF. A 1 possint, Catharina, $C V$ : possint Catharina $A \quad 3$ Camena $E$ : Camoena cett. 


\section{AD IACOBVM BELNAEVM ${ }^{140}$}

Ecce repente uno felix dat Gallia partu,

Doletum Iambico trucem:

Macrinum curua gnarum testudine, Diuum

Restinguere ardenteis minas:

Borbonium Latiis salibusque, iocisque fluentem,

Nugisque gratum seriis:

Vosque o Vultei, Brixi, Marthane, Ducheri,

Sacrae decora Poeseos.

Quaeris quid facio? numero, Belnaee, poetas,

Quos Gallia protulit ferax.

[41]

AD LECTORES

Parcite, Lectores, periturae parcite chartae:

Vt pereat, uestro non eget auxilio.

\section{FINIS}

${ }^{140}$ Epigr. 40: título: IACOBVM $C V$ : IAC. $A \quad 9$ numero, Belnaee, $V$ : numero Belnaee $A C$. Epigr. 41: 1 Parcite, $V$ : Parcite $A C$. 
Paucula quae aliter legi uolumus.

Pagina 9. libro priore, tertium uersiculum sic lege,

Nec gramen pastus, nec pinguem mulus auenam.

Libro eodem, pag. 11. uersiculum sextum sic lege,

Cura, labor, studium, delitiaeque meae.

Libro eodem, pag. 13. Epigramma de Rege \& Nauta, sic aliter conclusimus.

Per freta cum ueheret Regem diuersa, patremque

Submersum tumidis Nauita fleret aquis,

Rex illi, quis te tantus furor egit inepte,

Ausus ut infido sis dare uela mari?

Cui Vector, molli quid te Rex Optime lecto

Credis, ubi patrem scis periisse tuum? 


\title{
ANTONII GOVEANI
}

\section{EPIGRAMMATA.}

\author{
EIVSDEM
}

\section{Epistolae Quatuor}

APVD SEBASTIANVM GRYPHIVM

LVGDVNI

1540 


\section{ANTONIVS GOVEANVS IACOBO BELNAEO SALVTEM ${ }^{141}$}

1. SIQVANDO a studiis me grauioribus colligebam, Iacobe Belnaee, quae epigrammate digna uidebantur, epigrammate ut includerem laborabam: erat enim ad scribendum animus, erat ea facultas, quam litterarum usu prope nullo partam, et conquisitam, exercitatio uix aliqua confirmarat, non deerat tua, amicorumque omnium, inani fortasse spe, incensa tamen, atque inflammata cohortatio.

2. Verum, ubi ad nouos, et ueteres scriptores, qui hoc in genere clari, et nobiles extitere, cogitationem paulisper conferebam, debilitabar nescio quomodo, animoque frangebar: qui gratiam nouitati concessam, antiquitati autoritatem esse tributam uiderem.

3. Etenim, ut de Catullo dicam initio, magnus is profecto uir fuit, multarum magnarumque artium cognitione instructus, inuenit acute multa, Romane scripsit non pauca: ea tamen religionis metu omni deposito, quo nos impeditos atque irretitos tenet antiquitas, expendere si uelimus, nihil quod ad ingenii acumen, orationis puritatem pertineat, fortasse desideres, cur noua esse non possint, non intelligas.

4. Hunc M. Val. Martialis ut temporum longo est secutus interuallo, ita uictum superatumque in omnes ingenii partes reliquit. Cuius ut magnae et admirabiles eo in genere uirtutes eluxerint, caeterorum tamen neque studia restinxit, neque conatus retardauit.

5. Claudianus post multo laude, quam e Panegyricis duobus tulerat, neque eam quidem uulgarem, minime contentus, uisus est ad hanc quoque aspirare uoluisse, cuius uix umbram etiam leuem uidetur esse, meo sane iudicio, consecutus.

6. Nostra nimium multos tulit memoria, quos laudis huius cupiditas omnes uno tempore inflammauit. Horum ingenii partim, et industriae commendationem amplissime meruere, nouitatis partim gratia contenti, excitato uulgi plausu, doctorum iudicia contemnere potuerunt.

7. Ea nobis etsi deesse uel non potest, uel certe non debet, ita fuerit tamen optanda, ut si nullo ingenio, industria nulla commendetur, iubeam nihil esse ualituram.

8. Siquidem et uoto meo et amori nostro factum abs te abunde satis putabo, has nostrorum epigrammatum umbras ita si cognoscas, uitiis ut amanter minime concedas, neque

\footnotetext{
${ }^{141}$ Carta a Jacques de Beaune: Título: SALVTEM E: SAL. $A V \quad 1$ colligebam, $V$ : colligebam $A$
} litterarum $E$ : literarum cett. omnium, $V$ : omnium $A \quad 3$ impeditos $V$ : impeditos, $A . \quad 4$ M. Val. E: P. Val. cett. 
uirtutes, quae sentio quam sint exiguae, suo fructu priuatas esse patiaris. Fiet enim et Reipublicae litterariae commodo, et nostra et litteratorum summa omnium uoluntate, ut nos, qui et imperitorum uocibus, et doctorum tacitis iudiciis, et posteritatis uerecundia permouemur, uel deterriti plane, silentii fruamur securitate, uel certe ab eo impetu retardati, simus ad scribendum aliquanto tardiores. Vale. Lugduni X Calend. Febru. ${ }^{142}$

\section{LIBELLVS LECTORI}

MILLE locis castigatum quicumque uidebis,

Disce, precor, fuerit quae mihi caussa mali.

Me Pater immitis nonum seruabat in annum,

Maerentem diris condideratque locis.

Hic inter mures, tineas, blattasque iacebam

Squalidus, immissa maesta per ora coma.

Hic dormitanti si quid pecasse uidebar,

Certabant dorso uerbera saeua meo.

Nunc mihi lucis amor tardas crescebat in horas,

Nunc libertatis anxia cura nouae.

Forte reuoluebat positos ex ordine Fratres,

Quos studium multos euigilarat idem,

Elabor trepidans, gressumque per auia duco:

Orbe uagum toto septima Luna uidet.

Nuper at (heu miserum quo me mea fata trahebant?)

Ecce, meos oculos constitit ante Pater.

Olli sanguineis ardebant lumina flammis:

Spirabant saeuas uoxque colorque minas.

${ }^{142}$ Carta a Jacques de Beaune: 8 Reipublicae litterariae $E$ : Reipub. literariae cett. litteratorum E: literatorum cett. Febru. A: Febru. MDXL $V$.

Poema introdutório LIBELLVS LECTORI: 1 quicumque $E$ : quicunque cett. $4 \quad$ Maerentem $E$ : Moerentem cett. 6 Squalidus E: Squallidus cett. $\quad$ maesta $E$ : moesta cett. 
Vtque ait, amissae quae spes, fugitiue, salutis?

Palluit os: flauae diriguere comae.

Ter conatus ego pedibus me credere, ter me

Conantem tardi deseruere pedes.

Ilicet ille ferox lacerum crudeliter ora

Calcat humi duro terque, quaterque pede. ${ }^{143}$

Verberibus lacrimantem oneratque necatque: paterna

Nil pietas, blandae nil ualuere preces.

Vellere dum celsa conatur ab arbore ramos,

Vt daret extructis uiscera nostra rogis,

En celeres pedibus timor impiger addidit alas.

Matura uitae consuluique fuga.

In quae si rursum me fata pericula seruant,

Lector amice, uale, tempus in omne mihi.

${ }^{143}$ Poema introdutório LIBELLVS LECTORI: 24 terque, $A$ : terque $V 25$ lacrimantem $E$ : lacrymantem cett. 


\section{ANTONII GOVEANI EPIGRAMMATA}

[1]

D. FRANCISCO VALESIO REGI FRANCORVM SEMPER AVGVSTO

LIBELLVS $^{144}$

Saepe Patrem, tuus ut fierem, Francisce, rogaui:

O iustas quoties respuit ille preces.

Addebam precibus lacrimas: hic ille, quid, inquit,

Pessime, quid? uitam promeruisse putas?

[2]

CATHARINAE

Sume patrocinium nostri, Catharina, libelli,

Cum Domino ualde qui cupit esse tuus.

Quod non ante dedi, dare nunc, Catharina, licebit.

In Dominum scis me iuris habere nihil.

[3]

LIBELLO

Esse nouum si te quisquam, periture Libelle,

Clamitet, aetatem despiciatque tuam:

Si licet, et fas est, illi tu dicito, Lector

Heus bone, quid? Veteres nonne fuere noui?

${ }^{144}$ Epigr. 1: título: AVGVSTO E: AVG. $A V$

1 fierem, Francisce, $E$ : fierem Francisce $A$ fierem

Francisce, $V . \quad 3$ lacrimas $E$ : lacrymas cett.

Epigr. 3: 4 nonne $A$ : non ne $V$. 
RODORICO FERNANDO, IOANNIS LVSITANIAE REGIS LEGATO SANCTISSIMO $^{145}$

O Decus, o patriae, o gentis noua gloria nostrae, Vatibus argumentum ingens uariumque futuris, Tentarem, Fernande, lubens te imponere olympo, Et laudum cumulos dicendo aequare tuarum,

Haec tua ni uirtus hominum laude altior omni Erigeret sese, et caput inter poneret astra.

[5]

\section{ANDREAE GOVEANO FRATRI}

Miraris, genio sine

Quod scribo, inuidiae sollicitus nihil?

Mi Frater, genio sine,

Non est inuidiae sollicitus liber.

[6]

AVSONIO POETAE BVRDIGALENSI

Salua tibi ueterum maneat modo regula morum,

Ludat, ais, mixtis sobria Musa iocis.

Casta quidem Ausonio fuerit sat uita, poetae,

Non fuerit morum regula prisca satis.

${ }^{145}$ Epigr. 4: 2 ingens $V$ : ingens, $A 3$ Tentarem, Fernande, $V$ : Tentarem Fernande $A$. 
D. M. GVIDONIS RANGONII

HVC ADES GALLORVM QVISQVIS

NOMINI FAVES. GVIDO RANGONI-

VS, QVI ET NATVRAE, ET VIRTVTI,

ET GLORIAE, ET FORTUNAE VIXIT

SATIS, SIBI SE VIXISSE PVTAT PA-

RVM. CVR SI ROGAS, GALLIAE VI-

XISSE SE NEGAT SATIS.

Vestra licet dederim perituris nomina chartis,

O mihi me multo Pectora chara magis,

Nil me, nil miserum credo pecasse libellum:

Fungitur officio nostra Thalia suo.

Quae, meruit quoniam, pereat cum Vate: perire

Non meruere auida nomina uestra die.

[9]

\section{SEBASTIANO GRYPHIO LIBELLVS}

Quod legor, et uiuo, studiorum fida bonorum

Lima, Gryphi, sane gratia multa tibi.

Nam mihi semianimi praesto nisi forte fuisses,

Crede mihi, poteram non periisse semel. 
O fortunatam tanto te Fratre sororem,

Horrescit cuius terra, fretumque minas.

O fortunatam tali, tantoque Marito,

Cui quod agat, Martem nil dare posse uides.

Vtra tamen maior laus est? me iudice, certe

Altera Virtutis, altera Sortis opus.

In quo certarunt Fortuna, Scientia, Virtus,

Barollae exiguus contegit ossa lapis.

Illa tamen, memori si quid modo fidimus aeuo,

Casurum nullo tempore nomen habent.

Si quaeris tumulo quid non condantur eodem:

Exiguo a tumulo non potuere capi.

\section{CAROLO CANDELABRIO}

Dicitur a pica Cruceo Picardia: uerum,

Iudice me, nomen non habet inde locus.

Crediderim Pici ductum de nomine nomen:

Martia gens etenim est, Martia Picus auis.

\footnotetext{
${ }^{146}$ Epigr. 10: título: D. LIENORAE $A$ : LIENORAE $V$.

Epigr. 11: título: IOANNIS $E$ : IO. $A V$.
} 
Quos uno geminos partu, Lucilla, dedisti,

Cernitur officio functus uterque suo.

Ille Patris lacrimas miseri solatur, et ille

Optauit tecum, sustinuitque mori.

PINASSO

Vix gramen, pinguem nouit uix Mulus auenam

Iste tuus, pinguis durat at ille tamen.

Viuere uel nihilo, te praeceptore, Pinasse,

Non potuit Mulus non didicisse tuus.

[15]

\author{
CATHARINAE \\ E Gallicis Clementis Marotti ${ }^{147}$
}

Dum Catharina petis niue me candente, putabam

Igne carere niuem, nix tamen ignis erat.

En, quid agam, fallax niuibus si conditur ardor,

Si latet adstricta frigus, et ignis aqua?

An, Catharina, meo uiuit quae in corde fauilla,

Crescit frigoribus, uincitur igne pari?

${ }^{147}$ Epigr. 13: lacrimas $E$ : lacrymas cett.

Epigr. 15: título: E Gallicis Clementis E: E Gal. Clem. $A V$. 


\section{ARNOLDO LVCIO}

Si mihi nil debes, quid, Luci, indebita soluis,

Sponte tua factus debitor ipse meus?

Esse quid hoc dicam, nisi quod uis debitor esse,

Vt possis isto creditor esse modo?

[17]

D. M. ALDI MANVTII ROMANI ${ }^{148}$

Si nescis cur quae cinerem tegit urna Manuti,

Haec eadem Musas non tegat urna nouem:

Ignoras studio quanto perfecerit ille,

Incolumes possent ut superesse patri.

MARSIO

Sollicitas rauco Mariam, crebroque sussurro:

Momentoque, Senex, mille remandis Aue.

Hinc tibi promittis felicis praemia uitae,

Securusque tui fata diemque manes.

O quam te ludit fallax pietatis imago!

Non orare putat labra mouere Deus.

${ }^{148}$ Epigr. 17: 2 tegat $A$ : tegit $V \quad 3$ Ignoras $A$ : Ignoras, $V$. 
[19]

HVBERTO SVSANNAEO ${ }^{149}$

Quattuor ergo tibi Gallos placet esse Marones:

Visque tibi hos inter quattuor esse locum.

Hac ratione potes quintum me dicere, sextum

Me si quis peior esse poeta potest.

[20]

D. M. CIRETTI SENATORIS BVRDIGALENSIS

Cirettum patriae patrem, lumenque Senatus,

Tumulo sub exiguo uides.

Cui si forte parem lato uidisset in orbe

Iniuriae Mors uindicem,

Non patriae, uxori, natis, non legibus ipsis,

Fecisset hanc iniuriam.

[21]

IOANNI CRVCEO

Cum tonat, ad cellas trepido pede Vallius imas

Confugit. in cellis an putat esse Deum?

\footnotetext{
${ }^{149}$ Epigr. 19: 1 Quattuor $A$ : Quatuor $V \quad 2$ quattuor $A$ : quatuor $V$.
}

Epigr. 21: título: IOANNI $E$ : IO. $A V$. 
D. MARGARITAE VALESIAE REGINAE NAVARRORVM MAXIMAE ${ }^{150}$

O Regum soror et coniunx, o altera partus

Sors magni ingentisque, o ingens fratris imago,

Te canerem, nomenque tuum, nomenque tuorum,

Virtutemque aequatam astris, si pondera laudum

Tantarum exiguae possent attollere chartae.

IACOBO TEVIO

Sepositas epulas peruestigasse culina,

Esse stupidi negas, Teui.

Sepositas epulas peruestigasse culina,

Naris, fateor, est laus, Teui.

CATELLO, CVI NOMEN PARIS

Qui tantae uoluit tibi esse nomen

Vrbis, delitiae Catelle nostrae,

Virtutem ille tuam et sagacitatem

Tanto nomine uisus est uocasse.

${ }^{150}$ Epigr. 22: 2 ingestique, $V$ : ingestique $A$. 
PHILAENO

Vnde tui tibi tantus amor? compesce furorem.

Res cum riuali nulla Philaene tibi.

$$
\text { [26] }
$$

ZOILO $^{151}$

Zoile, uiue, uale, nostroque ignosce libello:

Nam simul ac morsus senserit ille tuos,

Quantum animis sese attollet, quantum efferet ore

Improbus? et durum dixerit esse Patrem,

Seque diu insontem foedas passum esse lituras.

Ah nescis quid sit, Zoile, cura patris.

\section{MARTIALI GOVEANO FRATRI}

Frater amice, tibi nostro dare carmina libro,

Esset in argutum mittere ligna nemus.

\section{BACCHO}

Quid tibi, Bacche pater, non stat Zebedeus ad aras,

Si caper est sacris uictima grata tuis?

Par utriusque nefas, par est iniuria, Bacche:

Hic est pernicies uitis, et ille meri.

\footnotetext{
${ }^{151}$ Epigr. 26: 4 dixerit $A$ : dixeris $V 5$ lituras. $A$ : lituras: $V$.
} 
Ensem tuum, dextram tuam Mors horruit:

Illam, o Aue, bellis inclytam Mors horruit.

$\mathrm{Nec}$ ausa iuuenta congredi tecum integra,

Graui senecta concutit uires prius.

Quid laudis esse possit in uictoria?

\section{LIBELLO}

Parue liber, si te quisquam despexerit, illi

Tu dicito, Pater meus,

Quae bona sunt, scripsit doctis, mala scripsit amicis.

Quid, o homo, hic uides tuum?

VENVS

E Gallicis Antonii Alacris

Me nudam Paris, et nudam me uidit Adonis,

Ille meus iudex, et meus alter amor.

Verum ubi me Rhodius nudam uidisset Apelles?

Fabula. uidisset scilicet ille Deam.

Sic tamen ad uiuum me qui depinxit, oportet

Nudatam Venerem uiderit ille quoque.

${ }^{152}$ Epigr. 29: título: OPTIMI ATQVE MERITISSIMI $E$ : OPT. ATQUE MERITISS. $A V$

Epigr. 31: título: E Gallicis Antonii E: E Gal. Ant. $A V$. 
[32]

\section{CLAVDIAE BELNAEAE ${ }^{153}$ \\ VENVS \\ Imitatio}

Me nudam Paris, et nudam me uidit Adonis,

Ille meus iudex, et meus alter amor.

Verum ubi ego, Belnaea, tuo sim uisa Parenti?

Fabula. uidisset scilicet ille Deam.

At uero talem genuit quicumque, necesse est

Nudatam Venerem uiderit ille quoque.

\section{IOANNI MICHAELI}

Fugisti, Michael, ferrum, flammamque, crucemque.

An non tibi uita pes melior?

\section{IOANNI CRVCEO}

Argutis epigrammatum libellis

Toto notus in orbe Martialis

Quaeris qui fuerit, negasque notum,

Argutis licet usque et usque chartis,

Ignotis hominem fuisse terris.

Mendacem arguis, ac tenes aperte:

Hispanum tamen esse schema nescis.

\footnotetext{
${ }^{153}$ Epigr. 32: 3 ego, Belnaea, $V$ : ego Belnaea $A \quad 5$ quicumque $E$ : quicunque cett. Epigr. 33: título: IOANNI $E$ : IO. $A V \quad 1$ flammamque, $A$ : flammamque $V$. Epigr. 34: título: IOANNI $E$ : IO. $A V$.
} 
Si luitura uiris licuit dixisse Latinis,

Hispanis cur non eluitura licet?

An licet, et licuit semper, semperque licebit,

Quique licere negat, nescit is esse luo?

[36]

AEMYLIO FERRETO

LIBELLVS

Emendaturis me terque quaterque fauillis

Deuouit durus, difficilisque Pater.

Spero equidem, nec spes animum deludet inanis:

Ignouit, dicas me placuisse tibi.

CATHARINAE

\begin{abstract}
AB AMORE MERCEDEM EXPECTEM, QVI NEQVE QVANTVM SIM PROMERITVS, VIDET, NEQVE EXPENDERE PER AETATEM POTEST? EN QVID SERVIRE ET PVERO, ET CAECO?
\end{abstract}

${ }^{154}$ Epigr. 35: título: IOANNI E: IO. AV. 


\title{
POSTHVMO $^{155}$
}

Contentus esse filiabus, Posthume,

Auctus duabus, sorte iam potes tua.

Plus quam petebas accepisti, Posthume.

[39]

IOANNI ROMANO CREMONENSI CASALINO MAIORITANO

Qui, Romane, tibi medicas Deus obtulit artes, Inuidit Aesculapio.

[40]

STEPHANO DOLETO

Te quid non laudem forsan, Dolete, requiras.

Id me tu melius facis.

\author{
[41]
}

BLANCHAE DVRAEAE IACOBI

\section{REGINALDI ALENII VXORI INTEGERRIMAE}

Quae tua nobilitas, uirtus, prudentia, morum

Suauitas, quae gratia,

Quae porro tibi mellitae facundia linguae,

$\mathrm{Tu}$ dicere queas optime.

${ }^{155}$ Epigr. 38: 3 Plus quam $V$ : Plusquam $A$.

Epigr. 39: título: IOANNI $E$ : IO. $A V \quad 1$ tibi $A$ : ibi $V$.

Epigr. 41: título: IACOBI ... INTEGERRIMA $E$ : IAC. INTEGERR. $A V$. 
HIERONYMO SORIO

Si Lusitanas Sori penetrarit ad urbes

Squallidus, impexus, exiguusque Liber,

Est meus, arripito, Patrique remittito caesum.

Quas meruit poenas non dedit ille mihi.

[43]

D. M. THOMAE MORI

VITAM TIBI TVA THOMA MORE IN-

TEGRITAS ADEMIT, GLORIAM VERO

PEPERIT SEMPITERNAM. CINERI

PRODEST, QVAE VIVO NON PROFVIT

INNOCENTIA.

NAVTA

Per freta cum ueheret Regem diuersa, patremque

Summersum tumidis Nauita fleret aquis,

Rex illi, te quis tantus furor egit, inepte,

Ausus ut infido sis dare uela mari?

Cui Vector, te quid molli, Rex optime, lecto

Credis, ubi patrem scis periisse tuum? 
[45]

ANDREAE GOVEANO FRATRI

Quem cepi, Frater, leporem, tibi ponitur: an non

Id uere est leporem perdere, et accipere?

[46]

LECTORI LIBELLVS

Sum breuis: hac una spero uirtute placere.

Est uitii Lector cum breuitate minus.

LIBELLO

Parue Liber patriasque manus, Patremque perose,

Te si lucis amor liberioris habet,

I, sequere ignotasque manus, et inhospita tecta,

Qui multo poteras tutior esse domi.

Quo tamen effugias alienae uerbera dextrae,

Peccauit dices, Lector amice, Pater.

[48]

PHAEDRO

Nescis cur ueteres nequeas superare canendo?

o\$ti sciomace/eij w\# fi/le. 
O Sancte, o terrae ac pelagi defuncte periclis, $\mathrm{O}$ inuicte animo, o magnum patriae ornamentum, Ten'ego commendare queam? Iouis aurea proles Musae alium date Moeoniden, en alter Vlysses.

[50]

MAXIMO

Importunus ego dicor tibi Maxime semper, Caseolus petitur cum tuus iste mihi.

Caseolum quid non mittis mihi Maxime totum?

Aut quid das uitio quod facis ipse, mihi?

\section{CATHARINAE}

Tum dabo pro xenio tibi me, Catharina, lubenter,

Reddideris postquam me, Catharina, mihi.

Si qua uidebuntur nostro uitiosa libello,

Si qua Latina minus, si qua faceta parum,

Excusata sui fuerint tibi tempore Patris.

Non eadem recte scribit, amatque dies.

${ }^{156}$ Epigr. 49: título: MERITISSIMO E: MERITISS. AV. 
Petrarchae uoluens diuina poemata Phoebus,

Haec est Laurus, ait, sit modo Laura licet.

Dixit, et e telo prostratam his increpat, I nunc,

I nunc, et magnos impia temne Deos.

Laura animam effundens Phoebum dileximus, inquit,

Peccatumque mihi sit coluisse Deum.

\section{AEMYLIO FERRETTO}

Nil quoniam Ferrette mihi nisi carmina, restat,

A Lusitano nil nisi carmen habes.

Caetera detraxit pridem Fortuna, reliquit

Quidquid ego poteram dicere iure meum.

\section{CATHARINAE}

Si quaeris Lugdunensi quid agamus in urbe,

Teque etiam nostri tangere cura potest,

Conqueror ignauam luci succedere noctem,

Humecto lacrimis, decipioque diem.

At lacrimis crudelis Amor non uincitur ullis:

E media cuius edita Mater aqua.

${ }^{157}$ Epigr. 53: 2 sit $A$ : si $V$.

Epigr. 55: 4 lacrimis $E$ : lacrymis cett. 5 lacrimis $E$ : lacrymis cett. 


\section{M. GABRIELIS TARRAGAE MEDICI}

Viderat, et poterat uenientem euadere Mortem

Tarraga: ast ultro sese fert obuius olli.

Quem Nati, et lacrimis Coniunx compellat obortis,

Quo properas? medicas quid non praecingeris artes?

Quo properas? uitam, ille inquit, pro morte pacisci.

[57]

\section{IACOBO BELNAEO ${ }^{158}$}

Dum capio leporem, blandi fugere lepores.

Res Belnaee duas non capit una manus.

[58]

\section{IOANNI REGI LVSITANIAE MAXIMO}

Cum tibi nec uires, nec opes in proelia desint,

Fortuna arbitrio stetque cadatque tuo,

Quid non finitimos ferro flammaque lacessis?

Quid non iniustum ius tibi ubique facis?

Haec tua diuina est, et plane regia uirtus,

Posse nocere quidem, nolle nocere tamen.

${ }^{158}$ Epigr. 56: 3 lacrimis $E$ : lacrymis cett.

Epigr. 57: 2 Res Belnaee $A$ : Res, Belnaee, $V$.

Epigr. 58: título: IOANNI $E$ : IO. $A V \quad 1$ proelia $E$ : praelia cett. 2 stetque $V$ : stetque, $A$. 
VIVENTI CATHARINAE POSVIT GO-

VEANVS: QVI MORTVAE NEQVE DE-

ESSE POTERAT, NEQVE SVPERESSE.

\section{ARCHIPOETAE}

De numero uatum uates detraxeris omnes,

Hoc sane fias Archipoeta modo.

[61]

\section{RESPONSVM AMORIS}

E Gallicis Ioannis Albenatii ${ }^{159}$

Indutus sapientis Amor uultumque togamque,

Tractabat publicis uel Ioue digna locis.

Illi ego, per Venerem, sequitur quid amaror amorem?

Ille mihi, solus ne sit amaror amor.

[62]

\section{SEBASTIANO GRYPHIO}

Sunt mala, sunt peiora Gryphi, sunt pessima plura.

Pauca tamen fuerint hac ratione mala.

\footnotetext{
${ }^{159}$ Epigr. 61: título: E Gallicis Ioannis E: E Gal. Io. $A V$.

Epigr. 62: título: SEBASTIANO $V$ : SESASTIANO $A$.
} 
Cum uates numeras quos secula nostra tulere,

Me uatum in numerum iure, Iacobe, refers.

Lance tamen uates si quisquam ponderet aequa,

Non ero, crede mihi, ponderis huius ego.

\section{FALSVS CVPIDO}

Barbara uelato Gelasina ocurrit Amori:

Occepitque Puer dicere, Mater aue.

Illa nihil contra: ac subito uelamine dempto

Ex oculis, doluit subrubuitque Puer.

Caece Puer, pudor unde tuus lacrimaeque? retecta

Hoc errare uides lumina posse modo.

\section{IACOBO REGINALDO ALENIO}

Quas tibi ego, Aleni, grates certissima proles

Heroum, magni generis magnum incrementum,

Quas tibi agam grates? uariis me erroribus actum,

Ignotum socias ultro mensaque, domoque.

\footnotetext{
${ }^{160}$ Epigr. 63: 1 numeras $A$ : numeras, $V \quad 2$ iure, Iacobe, $V$ : iure Iacobe $A$.

Epigr. 64: 5 Puer, $V$ : Puer $A \quad$ lacrimaeque $E$ : lacrymaeque cett.

Epigr. 65: título: IACOBO $E$ : IAC. $A V \quad 1$ ego Aleni $A$ : ego, Aleni, $V$.
} 
Quae nostris tua uel pietas, uel gratia rebus

Defuit? Hospitii quae non tibi praestita iura?

O mihi tam longae Superi dent tempora uitae,

Officiis tecum sat erit contendere quantum.

Spe quanquam sine uincendi contendere uanum est.

[66]

VIRGINIS PALLOR

E Gallicis Antonii Alacris ${ }^{161}$

Castra locarat Amor medio sub corde puellae,

Et nimis in tenero pectore durus erat.

Quodque magis doleas, uitam bibit artubus omnem

Ferreus ah nimium, sanguineusque Puer.

Hîc cor ubi affectas uires persensit, ab ore

Purpurei acciuit sanguinis auxilia.

\section{M. IOANNIS MONTANI IVRISPERITI}

Montanus trepidos media de morte trahebat

Viribus eloquii consiliique reos.

Lugebant erepta sibi sua numina Parcae,

$\mathrm{Nec}$ uolui fusis ferrea fata suis.

Haud mora, Montanum rapiunt sine legibus ullis.

Ah non sic fatis abstulit ille reos.

${ }^{161}$ Epigr. 66: título: E Gallicis Antonii E: E Gal. Ant. $A V$.

Epigr. 67: título: IOANNIS MONTANI IVRISPERITI $E$ : IO. MONTANI IVRISP. $A V$ 
Pauca damus, fateor, sed inepta epigrammata, Petre.

An non multa nimis dicere iure potes?

CVPIDINI

Te contra patriis, et auitis cingerer armis

Caece Puer: sed quam pareret uictoria laudem?

[70]

CORPORIS ET ANIMI IN MORBO CONTENTIO

E Gallicis Clementis Marotti ${ }^{162}$

Poscit opem Corpus medicam: Mens soluere terra

Aestuat, et medicas respuit usque manus.

Corpus humum, cognata leuis Mens suspicit astra.

Quam dirum, o Superi, terrificumque fremunt.

Mene ita, Corpus ait, tristi succumbere morbo?

Mens uero, inuisas me trahere usque moras?

Caeca es, ait Corpus. Mens contra, erramus uterque

Arbitrio summi stemus uterque Dei.

${ }^{162}$ Epigr. 70: título: E Gallicis Clementis $E$ : E Gal. Clem. $A V 5$ Mene $A$ : Me ne $V$. 


\section{CLEMENTI MAROTTO ${ }^{163}$}

Marotte magnum os Galliae,

E Gallicis tuis bonis,

Latina si facio mala,

Ignosce barbaro, et hospiti.

[72]

\section{CLYTAEMNESTRA \\ ORESTI \\ E Graecis}

An uentre, an mamma strictum uis condere ferrum?

Mamma aluit, uenter te scelerate tulit.

[73]

\section{PETRO CASTELLANO \\ EPISCOPO LIBELLVS}

Dum fugio durum terraque marique Parentem,

Orbe uagum Gallo septima luna uidet.

Exul ego, sine patre, tuo modo numine tutus,

Ignoto quamuis orbe, superstes ero.

${ }^{163}$ Epigr. 71: título: CLEMENTI E: CLEM. $A V$. 
CATHARINAE

Confiteor, duro longum obluctatus amori,

Nolebam Pueri subdere colla iugo.

Implorabam amens doctas cum Fratre Sorores,

Et uenatricis numina casta Deae.

Non mihi Phoebus opem misero, non Musa ferebat,

Non canibus toties Delia uisa meis.

Vicisti: uicisse tamen tibi gloria nulla.

Mollis homo cecidit uulnere Diua tuo.

[75]

HVGONI SALLELIO ${ }^{164}$

Eia age, cresce, meo dico si forte libello,

Ille mihi contra, non sapis hercle, Pater.

Cum rogito caussam, ridens sic ille, libellus

Vt placeam, speras posse placere librum?

[76]

\section{IACOBO TEVIO}

Si mihi quam stupida est, tam lingua diserta fuisset,

Dixissem quam sit lingua diserta tibi.

${ }^{164}$ Epigr. 75: 2 hercle, $V$ : hercle $A$. 
Hunc quisquis tumulum uides,

Pomponii tumulum uides,

Triuultii tumulum uides.

D. M. SIBYLLAE BARCIAE

Dum Pater ipse hominum coelis inferre Sibyllae Et mentem, et mentis terrea claustra parat,

En Tellus Natae collo dans brachia circum,

Patri animum, Matri reddito corpus, ait.

Nata piae iustas lacrimas miserata Parentis,

Liquit Materno corpus inane sinu.

[79]

\section{ANTONIO ARLERIO}

Prima meae uiridis deliramenta iuuentae

Nonne aliquid falso dicis, et esse putas?

An uero (nec enim tantum scelus excidat ore)

Sanum iudicium, lingua modesta tua est?

\footnotetext{
${ }^{165}$ Epigr. 77: título: POMPONII $E$ : POMP. $A V$.
}

Epigr. 78: 5 lacrimas $E$ : lacrymas cett. 
Quae tu pauca putas Epigrammata, Iane, putarim

Si bona, multa satis: si mala, multa nimis.

[81]

IOANNI ALBENATIO

Velle tuum nomen nostris me tradere chartis,

Est, puto, cum scriptis uelle perire meis.

D. M. IOANNI ALBERTI REOLANI

Ne tumulum Alberti exiguum mirere, uiator:

Nam quo potuit cumque obtegi

Albertus tumulo, doctae potuere Sorores,

Et Gratiae, et Pietas tegi.

FVNDANO

Si Fundane rogas quam sit bonus ille poeta

Publius, ille tuus, Coelius ille tuus,

Coelius ille tuus diuinae Persidos autor,

Optimus est medicus Coelius ille tuus.

${ }^{166}$ Epigr. 80: 2 bona, $V$ : bona $A$.

Epigr. 81: título: IOANNI $E$ : IO. $A V$.

Epigr. 82: título: IOANNI $E$ : IO. $A V \quad 2$ cumque $E$ : cunque cett.

Epigr. 83: 1 rogas $A$ : rogas, $V 2$ Publius, $A$ : Publius $V$. 
Vt coelo se Rufinus lapsum esse putarit,

Rufino ignotus fecit uterque parens.

\section{IACOBO BELNAEO ${ }^{167}$}

Ex iuramento ueteres Laurentius omnes

Emendaturus si potuisset, erat.

Si nescis uires ultra cur ausus, et artem,

In promptu caussa est, relligiosus erat.

BASSA

Coniugis (horrendum uisu) Bassae astitit umbra,

Quem Galla perederat lues.

Dixit et, o uitae quondam pars altera nostrae,

Si qua pietas, si qua est fides,

His miserum tandem flammis precor eripe: at illa,

Sudore tibi coniunx opus.

${ }^{167}$ Epigr. 85: título: IACOBO $E$ : IAC. $A V \quad 2$ erat. $A$ : erat $V$. 
Veneri

Quid, quod in aetatis Francisca Perusia flore

Erepta est, flesti tuque Puerque tuus?

Quid flesti? poterat siquidem nihil addere formae,

Virtuti, ingenio uirginis ipsa dies.

[88]

\section{CAROLO MARTHANO}

Dicunt pastores, dicunt me, Carole, uatem.

Dicunt pastores: sed non ego credulus illis.

[89]

\section{IACOBO BELNAEO ${ }^{168}$}

Ecce repente ferax uno dat Gallia partu

Doletum iambico trucem,

Macrinum curua narum testudine Diuum

Restinguere ardentes minas,

Borbonium Latiis salibusque, iocisque fluentem

Nugisque gratum seriis,

Vosque o Vultei, Brixi, Marthane, Ducheri,

Sacrae decora Poeseos.

$\mathrm{Si}$, quid agam, nescis, numero, Belnaee, Poetas,

Quos Gallia protulit ferax.

${ }^{168}$ Epigr. 89: 5 salibusque, $A$ : salibusque $V$. 
Nostra tuos oculos si pagina uenerit ante,

Diuinas, Meli, pertigeritque manus,

Parce precor chartis, misero quoque parce Parenti:

Nil ego, nil chartae commeruere meae.

Ter uoluere mori, ter edaci perdere flamma:

Conanti patriae ter cecidere manus.

Erro, loquax, uanus, mendax, effronsque petaxque,

Ingratus, nequam, dissimulator, iners,

Cur sit Ioannes Michael, si forte requiris

Infanti, Monachum scito fuisse Senem.

Sancte tuos casus, terrae, pelagique labores,

Longas, et innumeras uias,

Postponamne Ithaci uariis erroribus? ille

Fatis agitur ultoribus.

Sancte tua tu sponte fretum, terrasque, cadentem

Solem, atque nascentem uides.

Illum magnae agitant noxae maria omnia circum,

Virtus te animi tui inclyta.

${ }^{169}$ Epigr. 90: 5 mori, $A$ : mori: $V$.

Epigr. 91: 3 requiris $A$ : requiris, $V$.

Epigr. 92: título: MERITISSIMO E: MERITISS. $A V$

3 Postponamne $A$ : Postponam ne $V$. 


\section{IVLIO CAESARI SCALIGERO ${ }^{170}$}

Heroem te non Troiani nomen Iuli,

Scaligeraeue facit gloria prisca domus.

Quid tibi opus proauis? tua te facit inclyta uirtus

Semiuirumque Deum, semideumque uirum.

[94]

MEMORIAE SEMPITERNAE

CERCOPITHECVS CATHARINAE, QVI

HIC IACET VIATOR, CVM TRIDVI DO-

MINAE ABSENTIAM FERRE NON POS-

SET, VITA DECESSIT. ANIMALI HOMO

MORTEM NON INVIDEAM?

HECVBA

E Graecis

Haerere ut Natae uidit ceruicibus enses

Cisseis, niueas dilaniata comas

Incusat coelum, terras, incusat Achillem,

Heu pia, sed Natae nil ualitura Parens.

Hectora raptauit uiuus: secum auferet orco

Relliquias partus mortuus ille mei?

Quo nati Aeacidem laesistis crimine? saltem

Saltem utero immitis parceret umbra meo.

${ }^{170}$ Epigr. 93: título: IVLIO CAESARI $E$ : IVL. CAES. $A V \quad 2$ Scaligeraeue $A$ : Scaligerae eu $V$. 
Alma faue dixi gemini Dea mater amoris:

Respexit uatem casta Diana suum.

Obstupui, Diuaeque manus cum uoce tetendi,

Sum, Dea, sum casti miles amoris ego.

Illa nihil, subitoque, oculos auersa, refugit.

Hem, nequedum miseret te Catharina mei?

Vrar ego? moriar prudensque, sciensque, uidensque?

Sitque mihi uitae consuluisse nefas?

BAVIO

Incipio, dicis mihi saepius, esse poeta.

Si uerum narras, incipis esse miser.

Si qua suo fuerint, ut erunt, indigna parente,

Edita temporibus scito fuisse meis.

Hinc crudelis amor, hinc me torquebat egestas,

Turpior haec, multo durior ille tamen.

Sola mihi requies, et lenti temporis usus,

Non est ingenio fama petita meo. 
Dum tibi parue Liber noctesque, diesque laboro,

Constitit ante oculos casta Diana meos.

Dixit et, o leporum Vates oblite, canumque,

Cur opus aggrederis desidiose nouum?

Haec erat illa fides, mihi quam felicibus aruis

Vasconiae quondam perfide saepe dabas?

Quid tibi monstraui saltus? quid tecta ferarum?

Quid celeres egi per iuga summa canes?

Quid docui, dum feruenti sub Sole iaceret

Nostrum gramineo fessus uterque toro,

Quae canibus, quae sit lepori natura fugaci,

Quae uenatorem tangere cura potest,

Quae canibus dederit blandis medicamina Chiron?

Scilicet ut caperent irrita uerba noti.

Mitte sales Latios, interruptumque laborem

Perfice: nugarum quisque Poeta bonus.

Haec ait, atque oculis sese mortalibus aufert:

Attonitum uatem deseruitque suum.

Parue liber Diuae monitis parere necesse est:

Consulit illa tibi, consulit illa sibi.

Ignoscent tibi Virgilii fortasse libello:

Quam ueniam nunquam promereare Liber.

${ }^{171}$ Epigr. 99: 19 liber $A$ : liber, $V$. 
[100]

LECTORIBVS LIBELLVS

Parcite, Lectores, periturae parcite chartae:

$\mathrm{Vt}$ peream, uestra non eget autor ope.

\section{EPIGRAMMATVM FINIS}




\section{ANTONIVS GOVEANVS IACOBO REGINALDO ALENIO SALVTEM ${ }^{172}$}

\section{SI TV, uxor, liberique tui V. B. E. E. Q. V.}

2. Quae frigida, quae inepta, quae nobis indigna, Iacobe Reginalde, prior habuit editio, cuius generis multa post aliquanto quam in hominum manus uenissent, sentire coepimus apertius, defendet, siquidem, uolet, Belnaeus noster, qui eorum, ut nulla nostra uoluntate editionem praecipitauit, ita suscepit patrocinium.

3. Si mihi bene uis, quidquid apud te prioris erit editionis, quod ipsum a literatis omnibus summe contendo, paternae poenas temeritatis persoluet. Valde nos animo tremere, atque commoueri, posteritatis qualia sint de scriptis nostris futura iudicia, summa tibi asseueratione confirmo: de nostra memoria minus ut laborem, facit id, quod suis tempora iniqua esse ingeniis solere, et didicimus, et sumus experti.

4. Si cui nos forte in memoriae huius poetas extitisse uidemur emissarii, is uero intelligat hos a nobis commendari, hos ad scribendum ridendumque liberius inuitari, ea denique licentia, quae summa esse hoc in genere solet, moderata esse nos usos, atque temperata.

5. Libere apud te tanquam apud me alterum, animi mei sensus deponam. Extitimus de repente Goueani, nescio qui, nouum sane, ut ego interpretor, atque inauditum ineptorum genus: qui cum poetae et dici uelimus, et haberi, scribamus autem nihil nisi flagris dignum (iuuat enim, et certe decet aduersus ignorantes sua in dicendo abuti libertate) quid de nobis non pollicemur? nihil nos nostri, nihil posterorum, nihil aequalium, nihil maiorum pudet. Ineptire nos, patior equidem facile, melius enim nihil possumus, arduaque sequentes honestum est uel in postremis consistere, tam esse inanes ferre dissimulanter neque potui, neque debui.

6. Errant qui me eorum uel laudi uel ingeniis putant inuidisse, errant mihi crede Iacobe Reginalde: nihil in illis tantum, ut mwmh//sasqai mihi sit, quam mimh//sasqai facilius: sed tibi ac literatis omnibus esse uolui testatum, me, cum quid omnes possemus, intelligerem (in eodem enim aut imperitorum sumus, aut ementium albo) quemadmodum loqui de nobis ac sentire deberemus, prudenter sane peruidisse.

\footnotetext{
172 título: IACOBO $E$ : IAC. $A V \quad 2$ Iacobe $E$ : Iac. $A V \quad$ aliquanto $A$ : aliquanto, $V 3$ apud te $A$ : apud te, $V \quad 5$ de repente $A$ : derepente $V \quad$ poetae $E$ : poëtae $A$ poëtas $V$
} 
7. Male mihi Di faciant, mihi si quisquam minus tribuit quam ego, imponit, blanditur minus: multa e nostris in uulgus probantur, multa a mediocriter eruditis, multa a poetis etiam ipsis quae ${ }^{173}$ mihi ne luce quidem digna uideri possunt. Quod si iurati ut caeterarum rerum artifices, sic poetae crearemur, neque tanta poetarum esset fora $\backslash$, neque a doctis ratio haec scribendi spreta, atque contempta ingeniis esset agrestioribus relicta. Sed heus tu uale: effugiet fera, nisi aduolo: Venatio longas

Non didicit tolerare moras. -

ita enim a nobis scriptum est. Iterum uale.

1737 ipsis quae $A$ : ipsis, quae $V$. 


\title{
ANTONII GOVEANI
}

\section{Epistolae Quattuor ${ }^{174}$}

\author{
ANTONIVS GOVEANVS IOANNI ROMANO CREMONENSI CASALINO \\ MAIORITANO SALVTEM
}

TVIS in me meritis, Ioannes Romane, satisfacere eo possum sane minus, quo contendo magis: factum nisi tibi a me abunde satis putas, dum memoria teneo quod obliuisci non possum. Ea cum te mente esse sentirem, data a nobis opera est, ut et benignitatis tuae et memoriae meae ad posteros qualecumque, meum tamen perueniret testimonium: erit fortasse tua commendatione sempiternum. Vale.

\section{ANTONIVS GOVEANVS CATHARINAE SALVTEM}

EA VIS amoris est, Catharina, ut nobis cum tacere minime sit integrum, ineptire sit etiam necesse. Quid agas? ita hercle natus sum, ut amoris mihi sit quam ingenii gloria iucundior. Vale.

\footnotetext{
${ }^{174}$ Quattuor E: Quatuor cett.

GOVEANVS IOANNI $E$ : GOVEANVS IO. $A V \quad$ SALVTEM $E$ : Sal. $A V$.

1 meritis, Ioanne Romane, $V$ : meritis Ioannes Romane $A$.

2 teneo quod $A$ : teneo, quod $V \quad 4$ qualecumque $E$ : qualecunque cett.

CATHARINAE SALVTEM $E$ : CATHARINAE SAL. $A V$

1 est, Catharina $V$ : est Catharina $A$.
} 


\title{
ANTONII GOVEANI EPISTOLAE QVATTVOR ${ }^{175}$
}

\author{
Epistola Prima
}

GOVEANVS CATHARINAE

$\mathrm{EN}$, Catharina, tibi, quam non fortasse requiris,

A Lusitano littera missa uiro.

Quae tibi non potui praesenti dicere lingua,

Nescio quo potuit scribere dextra modo.

Ter calamus cecidit digitis, ter uerba negauit

Musa, ter inceptos destituitque sonos.

Ter conatus ego fletus cohibere, ter illi

Vberius grauidis prosiluere genis.

Tandem ubi per lacrimas licuit, sed flebilis orsa est,

Singultu tremulos excutiente sonos.

Aspice uerborum caecasque rudesque figuras:

Aspice quam multis multa litura locis.

Da ueniam lacrimis (ueniam, Catharina, merentur)

Si minus est oculis littera digna tuis.

Venimus huc, credo, fatis auctoribus ambo:

Et patrium maestus liquit uterque solum.

Beia mihi patria est, fuerat Pax Iulia priscis:

Iulius hoc dederat nomen habere loco.

Tres uidi fratres, tres me uidere sorores:

Sorsque tui partus ultima, Mater, ego.

${ }^{175}$ QVATTVOR E: QVATVOR cett. 9 lacrimas E: lacrymas cett. 13 lacrimis $E$ : lacrymis cett. 15 auctoribus $E$ : autoribus cett. 16 maestus $E$ : moestus cett. 
Gallia tres studiis florens ignobilis oti

Ceperat, accesi quartus et ipse tribus.

Annos detinuit populosa Lutetia septem,

Crescentem studiis erudiitque bonis.

Me tamen a primis bello sacrauerat annis,

Vt successorem laudis haberet auus.

At Mars alter erat, bella altera, et altera castra,

Altera militiae cura futura meae.

Hinc me Burdigalae falcatum littus in arcum

Accipit: huc Frater uenerat ante meus.

Hic rursum Musas studio complectimur omni:

Hic primum canibus Delia uisa meis.

Hinc me post uarias fatalis Auinio terras

Accepit, fatis debita terra meis.

Nobilis illa uiris, et muro nobilis alto,

Formae nobilior nobilitate tuae.

Cuius ut ad nostras rumor sese attulit aures,

Tentari sensi pectora nostra rogis.

Heu quantum terrae, quantum maris aequor araui,

Cassibus ut caperer hospita praeda tuis?

Hic nomen, Catharina, tuum, patriamque rogaui,

Quis pater et proaui, quod genus omne tuum.

Nobile simplicitas dederat tibi candida nomen:

Et pater a proauis regibus ortus erat.

Visendi incessit misero male prouidus ardor:

Scilicet ut uisu laederer ipse meo.

Vt uideo, ut pereo: subitoque accensa fauilla

Ingeminat uires multiplicatque suas.

Istud erat cur te, famosa Lutetia, liqui,

Aonios demens deseruique lacus.

Istud erat cur Burdigalam claramque Tholosam

Neglexi, terras appetiique nouas.

At uidisse fuit, quoniam sic fata, necesse: 
Nec uisa potui non periisse Dea. ${ }^{176}$

Sensistique ignes, si uis modo uera fateri,

Materiamque tibi saepe dedere ioci.

O medio haerebat quoties mihi lingua palato,

Et mihi pro lingua lucidus ignis erat?

Pro lingua, gemitus, lacrimae, suspiria crebra? ${ }^{177}$

Quid facias? saeuus uerba coercet amor.

Quin etiam cupiens omni tibi parte placere,

Ingenii coepi prodere signa mei.

Doctorum tenui totis sex mensibus aures:

$\mathrm{Nec}$ fuit ingenio fama sinistra meo.

Quod si quem nostri forsan iuuere labores,

Gratia sit meritis tota ferenda tuis.

Quid uerbis opus est? satis imprudenter amaui.

Scis quam non facile dissimuletur amor.

Id ne quaeso nega: cupias fortasse negare.

Hei mihi, quam, posses iure negare, uelim.

Ac uellem, ut cuperes id tu, Catharina, negare,

Sic mentiretur littera nostra tibi.

Quid iam sperassem fatis accedere nostris?

En alius rerum nascitur ordo mihi.

Quo Superi, quo me tandem, quo mittitis? ibo

Longius hinc sine te, te, Catharina, sine?

Istud erat cur iactatum terraque marique,

His demum placuit constituisse locis?

Hem quid ego admisi? quae non ego numina demens,

Quos ego non colui demeruique Deos?

O possem sensus utinam tibi scribere nostros:

Sentires uerus quam meus esset amor.

${ }^{176} 54$ periisse $A$ : perisse $V$.

17759 lacrimae $E$ : lacrymae cett. 77 terraque $V$ : terraque, $A 83$ lacrimasque $E$ : lacrymasque cett. 84 lacrimas $E$ : lacrymas cett. 
Sentires, lacrimasque dares, miserata dolorem:

Ad lacrimas quamuis nil mala nostra tuas.

Forte erit ut dicas: me si Goueanus amasset,

Mouisset precibus fata Iouemque suis.

Altera non esset tellus quaerenda per orbem,

Non alter rursum sollicitandus amor. ${ }^{178}$

Crede mihi, nondum uisam Goueanus amauit,

Certauitque sua fata mouere prece.

Altera terra tamen misero quaerenda per orbem,

Non alter fuerit sollicitandus amor.

Quas me cumque ferent Superi referentque sub oras,

Quae misero cumque gens adeunda mihi,

Vt tuus ipse fui, cum non mihi uisa fuisses,

Sic ero quod superest, tempus in omne tuus.

Siue, quod auertant Superi, mihi uita supersit,

Siue peregrinus contegat ossa lapis.

17888 sollicitandus $E$ : solicitandus cett. $\quad 92$ sollicitandus $E$ : solicitandus cett. $\quad 93$ cumque E: cunque cett. 94 cumque $E$ : cunque cett. 


\section{EPISTOLA SECVNDA}

\section{CATHARINA GOVEANO}

QVANDO erit ut lacrimis possis mollescere nostris? ${ }^{179}$

Quando erit ut uictas des, Goueane, manus?

Lusisti quae te numquam decepit amantem.

Res est plena leuis credulitatis amor.

Me mea simplicitas. culpae non plectimur ergo.

An non illa tuo digna fauore magis?

Dixisti quoties, ego te, Catharina, relinquam?

Ante tuus refluas Sequana uertet aquas.

At dixisse parum: res est Ioue credita teste.

Vltor perfidiae sit precor ille tuae.

Sequana quo properas? uirides quo tenditis undae?

Altera periuro terra petita uiro.

Partus et alter amor, nec prisco tangitur igne:

Quamque iterum uiolet, altera pacta fides.

Ima tibi o utinam tellus, scelerate, dehiscat:

Iuppiter aut missi fulminis igne cremet.

Aut te gurgitibus rapiat te surdior unda

Perfide, nec gemitus audiat illa tuos.

Corporeque incesto pascas genus omne natantum,

Ossaque post longo tempore ructet aqua.

Haec hic, haec illic fulua spargantur arena.

$\mathrm{Nec}$ sit qui tumuli curet honore tegi.

Quid precor infelix? malim te uiuere, malim:

Tristior at morte uita sit illa tamen.

1791 lacrimis $E$ : lacrymis cett. 3 numquam $E$ : nunquam cett. 20 ructet $V$ : rutet $A$. 
Hospes in ignota uiuas inglorius urbe:

Sit fortuna tamen inuidiosa tua.

Deneget aequor iter, tellus ignota fauorem:

Multa tibi terrae, plura minentur aquae.

Sis miser, illudant misero, calcentque iacentem

Si quos officiis demeruisse potes.

Sis miser, et soli mihi sis miserabilis ipse:

Commouear tuis indoleamque malis. ${ }^{180}$

Et quos flagitio non irritaueris ullo,

Coniurentque omnes in tua damna Dei.

Nil ubi non tuleris, leuior sit crimine culpa:

Pacatumque tibi confiteare Iouem.

Di maris et terrae, Di qui Iouis astra tenetis,

Imperiuratae quique praeestis aquae,

Annuite, et uotis omnes subscribite nostris:

Expleuit partes iustior ira suas.

Venisti, ut terra posses discedere nostra:

Impositam mediis desereresque rogis.

Demophoon pelagi uariis erroribus actus

Intrauit portus, Thracia Phylli, tuos.

Intrauit, regnoque tibi, lectoque receptus

Commisit rapidis uela fidemque Notis.

Minoin Theseus, et te delusit Iason

Hypsipyle, meritis gratus uterque parum.

Phryx profugus, miseraeque Asiae desertor, Elissam:

Teque tuus, citharam docta puella, Phaon.

Lusisti tu me, ne non ego femina credar.

Haec semper sexus fata fuere mei.

At mea conditio peior, quia, perfide, scis tu,

${ }^{180} 32$ Commouear $A$ : Commouearque $V$

44 portus, Thracia Phylli, V: portus Thracia Phylli 
Infelix de te gaudia nulla tuli.

Cedere certus eras miseramque relinquere certus,

Se mihi cum fallax insinuabat amor.

Serus amor mentem multo inclementius urit,

Compensatque suas asperitate moras.

Te per ego has lacrimas oro mala nostra leuantes, ${ }^{181}$

Per si quisquam hominis pectore sensus inest,

Consule quae nostrum poscat medicamina uulnus,

Vulneris aut cesset qua ratione dolor.

Consulis expectem qui non rediturus abisti?

Scilicet haec fidei sit tibi cura tuae.

Ales Amor, te si quidquam mortalia tangunt,

Ales Amor, uotis saepe uocate meis,

Ales Amor, sequere erronem terraque marique:

Sentiat iratos numen habere Deos.

Ardeat igne nouo: prisco non pungitur igne.

Flagret, et occultum pectore uulnus alat.

Haec, Goueane, mihi ueniet cum fama per aures,

Secura fuerit nil mihi morte prius.

\footnotetext{
18159 lacrimas $E$ : lacrymas cett. 67 Amor, $V$ : Amor $A \quad$ terraque $V$ : terraque, $A 71 \quad$ Haec,
} Goueane, $V$ : Haec Goueane $A$. 


\section{EPISTOLA TERTIA}

\section{GOVEANVS CATHARINAE}

EXPECTAS tibi dum mittam, Catharina, salutem?

Hei mihi, quo careat mittere nemo potest.

Luna quater latuit, nec enim me tempora fallunt,

$\mathrm{Nec}$ tua sunt oculis reddita uerba meis.

Quae potuere tuam tenuisse obliuia mentem?

Ipse tuus, domina tu mihi nuper eras.

$\mathrm{Nec}$ libertatis pretium mihi blanda poposci

Oscula: uix tanti uita putanda fuit.

Non petii amplexus, audentem Ixiona saeuae

Dilacerant medium, diripiuntque rotae.

Haec tua nobilitas, uitae sine crimine mores,

Hic decor, arbitrii iura tulere mei.

Atque utinam neque forma tibi, neque cana fuisset

Nobilitas, mores nec sine labe tui.

Vixissem multo sane felicior: esses

Nec mihi tu domina, nec tibi seruus ego.

Iamne tuus non sum, neque me facis ipsa tuorum? ${ }^{182}$

Crimine quo potui non tuus esse meo?

Si tibi noster amor paucis euanuit horis,

Cur non ingenii sum, Catharina, tui?

Longa mihi geminant conceptam tempora flammam,

Multiplicantque meos tempus et hora rogos.

Tune meis lacrimis lacrimas sine fine dedisti,

Iunxistique meis talia uerba sonis?

${ }^{182} 17$ Iamne $A$ : Iam ne $V 23$ Tune $A$ : Tu ne $V$

lacrimis lacrimas $E$ : lacrymis lacrymas cett. 
Hinc potes auelli? dominam, fugitiue, relinques?

Haeccine mentiti finis amoris erat? ${ }^{183}$

Te quid ego infelix, me quid tu semper amasti?

Dic, ubi nostra fides? dic, ubi noster amor?

Haec nisi me fallo, neque sum mihi credulus ipse,

Vox non occulti testis amoris erat.

Testis amoris erat, hoc saltem parce negare.

Tam castus non est dissimulandus amor.

Et tua (nam recolo) numquam mihi dicere lingua

Supremum potuit sustinuitque uale.

Nunc tibi si rerum facies indigna mearum

Despicitur, sortis crimine laedor ego.

Despicienda tamen fortunae iniuria nostrae

Non uenit, at potius illa dolenda uenit.

Illa dolenda uenit saltem, lacrimisque iuuanda:

Id pietatis erat officiique tui.

Sola tamen fortuna deest, non altior omni

Mens casu et duris durior usque malis.

Non exculta deest studiis melioribus aetas,

Non deest ingenio fama benigna meo.

Non deest nobilitas ab auis proauisque relicta,

Successor cuius ordine factus ego.

Non deest (quo recreor) uiridisque ualensque iuuenta,

Non spes ad magnos difficilesque gradus.

Sola mihi fortuna deest, Catharina: sed illa

Non uno semper statque manetque loco.

Vltima contigeram, fateor: hinc turpis egestas,

Hinc pudor, hinc saeuus bella mouebat amor.

Est tamen hic quod ames, possis quod spernere non est.

Endymion pastor, pastor Adonis erat.

18326 erat $A$ : erit $V \quad 33$ numquam $E$ : nunquam $c e t t$.

lacrimisque $E$ :

lacrymisque cett. $\quad 51$ contingeram $A$ : contingerant $V$. 
Dum Paris Idaeis pascebat collibus agnos,

Pauper erat, Nympha pauperis uxor erat.

Nil ego tale peto: numero me iunge tuorum:

Ipse tibi uitae debitor huius ero.

An neque te nostri tenuere obliuia, sortis

Nec despecta tibi forma pudenda meae?

An tibi suspitio est alios me quaerere amores,

Et captiua nouo subdere colla iugo?

Caussa quidem iusta est et amoris plena sagacis:

Illa tamen nobis significanda fuit.

Non ea uis animo, nec amores tempora poscunt

Nostra, nec in miseris se nouus abdit amor.

Atque utinam uitae ratio tibi cognita nostrae

Esset, $a b$ hac uacuus suspitione forem.

Viuimus, at uitam, lucemque, hominesque perosi: ${ }^{184}$

Estque puto ad lacrimas uita relicta mihi.

Conquerimur tardos nocti succedere soles,

Decipimus lacrimis eximimusque dies.

Atque utinam lacrimas oculi, Catharina, negarent:

Deficeret tantis obruta uita malis.

O quoties breuibus numero pro mensibus annos?

It quoties longa tardior hora die?

Ignauam quoties mortem lentamque uocamus?

O precibus quoties surduit illa meis?

Solaque curarum lenimen Musa mearum

Compescit lacrimas officiosa meas.

Carminibus lenit interpellatque dolores,

Quaque potest animum garrulitate leuat.

Dicitur, erepta Briseide, maestus Achilles

${ }^{184} 69$ uitam, lucemque, $A$ : uitam lucemque $V$

lacrymis cett.

moestus cett.
73 lacrimas $E$ : lacrymas cett.

84 lacrimas $E$ : lacrymas cett.
70 lacrimas $E$ : lacrymas cett.

80 lacrimas $E$ : lacrymas cett.

85 siluas $E$ : syluas cett.
72 lacrimis $E$ :

83 maestus $E$ : 
Bistonia lacrimas continuisse lyra.

Cum traheret silvas deserti ad Strymonis undas

Orpheus, Eurydice rapta bis uxor erat.

Naso Tomitanis exul dum uiueret oris,

Per quam nullus erat, artis egebat ope.

Aspice ne tecum falso tibi somnia fingas,

Et peragar falsi criminis ipse reus.

Hei mihi, uenturo non est locus ullus amori,

Nec capiunt plagas pectora nostra nouas.

Forsitan id metuis, quoniam nil contigit, esset

Vel mihi dulce tuum, uel tibi dulce meum.

Dulce nihil fateor, tamen a te quidquid amarum est,

Dulce fit, et propriis mulceor ipse malis.

Quid facias? adimit sensus mentemque Cupido:

Contingitque uafer melle uenena Puer:

Testor ego has lacrimas tot quae fecere lituras, ${ }^{185}$

Testor et haec animi conscia signa mei,

Te, numenque tuum, quo non praesentius ullum,

Esse uelis, nolis, me, Catharina, tuum.

Meque fuisse tuum, cum non mihi uisa fuisses,

Et fore, quod superest tempus in omne, tuum,

Et duraturum, duret dum uita. Beatus

Ille mihi, potuit quisquis amando mori. 


\section{EPISTOLA QVARTA}

\section{GOVEANVS CATHARINAE}

PERLEGE: quid dubitas? num te nouus impedit ardor?

Non uenit hostili littera scripta manu.

Aspice nostrarum lacrimarum signa lituras, ${ }^{186}$

Verbaque pro domino nil ualitura suo.

Perdere uerba tamen miseris in parte bonorum est:

Et desperatam quaerere rebus opem.

Me dum uix tulerat sex mater Inesia menses,

Vixque mihi uitae spiritus ullus erat,

Haec cum per noctem species oblata parenti est.

Hei mihi, femineus non erat ille metus.

Me procul a patria telo transfixerat infans;

Caecus erat, matri si sit habenda fides.

Ah mater, uates nimium mihi uera fuisti.

En in transfixo pectore tela manent.

En longe patria est, longe uos estis amici,

En fugit ad lacrimas hospita terra meas.

O utinam uastum numquam maris aequor arassem,

$\mathrm{Nec}$ portum intrassem Gallica terra tuum.

Non morerer, Catharina, sciensque, uidensque: fuisses

Nec tu uisa mihi, nec tibi uisus ego.

Nec crudelis amor, quis enim puer ille fuisset?

Fixisset iaculis mollia corda suis.

Quid queror? aut quis ego? fatorum immobilis ordo

Sic erat: in dominos ius habet ille Deos.

1863 lacrimarum $E$ : lacrymarum cett. 10 femineus $E$ : foemineus cett.

11 infans; $V$ : infans. A. $\quad 16$ lacrimas $E$ : lacrymas cett. 17 numquam $E$ : nunquam cett. 
Mens fer et obdura: culpae tibi conscia non es.

Si quid erit, merito quod patiare, dole.

Non mihi laesus Amor, Matris non spreta potestas,

Non sum Tydidae criminis auctor ego. ${ }^{187}$

Non data deserui duce signa Cupidine: semper,

Semper militiae dux fuit ille meae.

Non detrectaui noctuque diuque labores,

Pro quibus a Puero gratia nulla mihi.

Hic si culpa mea est, et culpae laedimur, ergo

Iam dubito iustos an rear esse Deos.

Parce infelices sceleris damnare, Cupido:

Vatibus infensum non decet esse tuis.

Dic mihi quid feci, nisi quod bene semper amaui?

Esse reus possum criminis huius ego.

$\mathrm{Tu}$, Catharina, potes caussae subscribere nostrae:

Pectoris integritas est tibi nota mei.

Sis iniusta licet, neque te clementia tangat,

Sperem iudicio uincere posse tuo.

Me miserum, quali dico sub iudice caussam.

Aspice quam nobis caussa det ipsa fidem.

Te non officii iugis obseruantia nostri,

Te non castus amor, non sine labe fides,

Non seruata mihi uariis constantia rebus

Adducit, nolis immemor esse mei.

Id sat erit misero, nec amari poscimus abs te:

Oderis, ast odii caussa sit unus amor.

Aspice qua seruire tibi sum lege paratus,

Spiritus inuisas dum trahet iste moras.

At, bene dum reputo, legem quis ponat amori?

Quem non imperiis continet ille suis?

${ }^{187} 28$ auctor $E$ : author cett.

ergo; $V$

43 miserum, $V$ : miserum $A$. 
Oderis ergo licet, nostri sis immemor usque,

Sum tuus, et maneo tempus in omne tuus.

Esse tuus possum, contra licet aspera pugnes:

At tuus ut dicar tu dare sola potes.

Non merui, fateor: merito sine gratia crescit

Virtutique patet latior ara tuae.

Ne cadat ante diem, uiridis miserere iuuentae:

Ossa peregrina neue tegantur humo. ${ }^{188}$

Ingenii miserere mei: me pungere nuper

Sobrius aeterni coepit honoris amor.

Vtque tuum legerent nomen post fata Nepotes,

Saepe mihi in laudes Musa uocata tuas.

Forte erit ut nostri uiuant monumenta laboris,

Inque manus serae posteritatis eant:

Virtutisque tuae fiat mea pagina testis.

Crede mihi, fugiunt carmina sola diem.

Sin te non miseret nostri, miserere parentis:

Vltima sors partus illius ipse fui.

Tres illi nati, quos Gallia detinet omnes:

Nec desiderium quo minuatur habet:

Sola domo maeret uidua natosque patremque.

I nunc, et leti caussa ferare mei.

Et Lusitanis absit licet illa sub oris,

At celeris nimium nuntia, fama mali.

Quod si te forsan possent mala nostra iuuare,

Quae paterer, sane ferre suaue foret.

Sin te nulla iuuant aliena incommoda, uerum

Nil opus est rapidis fundere uerba Notis.

Vtere iure tuo, quoniam sic fata tulerunt:

Eripe quae sola est uita relicta mihi.

${ }^{188} 62$ neue $A$ : ne ue $V \quad 69$ testis. $A$ : testis: $V$

75 maeret $E$ : moeret cett. 
Ibimus ad miseras, ualde nisi fallimur, umbras,

Quas dirus caeca tabe peredit Amor.

Ibimus, et mecum silua condentur eadem

Hypsipyle, Dido, Laodamia, Procris. ${ }^{189}$

Ibimus, et lacrimas omnes miscebimus una.

Crede mihi, sexus laus erat ista tui.

Iliacam ut uidit classem procedere uelis,

Ipsa sua Dido concidit icta manu.

Vidit Abydenum iactatum Sestias undis,

Se simul in tumidas praecipitauit aquas.

Quid referam Thisben? quid te patre digna Catone

Porcia? quid gladios Arria casta tuos?

Quid Procrin, Hypsipylem, reliquasque Heroidas omnes,

$\mathrm{Tu}$ quibus es maior sanguine, laude minor?

Grandia mentiti qui praemia ferret amoris

Vidimus, at noster morte luetur amor.

Ossa tegentur humo, cum spiritus ossa relinquet,

Inque sepulcrali marmore carmen erit.

Scire meae caussam mortis quicumque laboras,

Criminis et summa quae sit, amator eram.

\section{FINIS}

18988 Hypsipyle $E$ : Hypsiphyle cett. Laodamia $V$ : Laodomia $A \quad 89$ lacrimas $E$ : lacrymas

cett. una. A: una; $V \quad 95$ Thisben $E$ : Thysben cett.

97 Hypsipylem E:

Hypsiphylem cett.

103 quicumque $E$ : quicunque cett.

FINIS A: deest $V$. 


\section{ANTONIVS GOVEANVS IACOBO BELNAEO SALVTEM}

DIC mihi uerum, num ita Ouidius? uolui quidem certe: quod si aut industria sumus, aut ingenio consecuti, magnum quiddam atque incredibile nostris hominibus perfecimus. An uero ille cultior, magis sua sponte fluens, copiosior? Nihil me caela: malo iudicii illius tui quam beneuolentiae testimonium. Haec si tui erunt palati, dabo ubi fame abuti possis. VALE. 


\section{Capítulo 5}

\section{TRADUÇÃO DA OBRA}

Apresenta-se, a partir da próxima página, a tradução integral das obras epigramática e elegíaca de Antônio de Gouveia, na mesma ordem de sua publicação original e de sua exposição no capítulo anterior desta tese.

A fim de facilitar o cotejo com o texto latino, reproduzimos, na folha à esquerda, o original, ocupando os versos das páginas da tese. As folhas com a reprodução do texto latino não fazem parte, estritamente falando, da tese, e sua numeração, em algarismos romanos, teve a exclusiva finalidade de permitir a montagem e encadernação do volume. 


\author{
de \\ ANTÔNIO DE GOUVEIA, \\ POETA PORTUGUÊS
}

\title{
DOIS LIVROS
}

DE

EPIGRAMAS

\author{
À MORTALIDADE
}

JUNTAMENTE COM O DIA

Lyon

Impressão de Sébastien Gryphe

1539 


\title{
PARA A MORTALIDADE
}

Sendo ele próprio mortal,

\author{
Gouveia
}

consagra toda esta obra a ti, mortalidade. 


\section{ANTÔNIO DE GOUVEIA A JACQUES DE BEAUNE. SAUDAÇÕES.}

1. Quando por vezes eu me recobrava de pensamentos mais sérios, se eu via algo que pudesse ser escrito com agudeza, me esforçava para concluí-lo em forma de epigrama; principalmente porque, para escrever, havia disposição, havia capacidade - a qual, nascida em meio a quase nenhuma experiência das letras, e perseguida com empenho, algum exercício pôde fortalecer -, e porque se acrescia o estímulo dos amigos, acompanhado de uma esperança talvez vã, mas, apesar disso, aceso e inflamado.

2. Mas quando eu voltava brevemente meu pensamento para os escritores novos e antigos que sobressaíram aclamados e famosos neste gênero, eu me sentia de algum modo fraquejar e desanimar: eu compreendia perfeitamente que aqueles não desagradavam em nome da inovação, e estes eram aprovados por conta da tradição. Dentre estes últimos, eu não podia abusar de um com o propósito de glorificar meu trabalho, e não queria usar de outro.

3. Com efeito, para falar inicialmente de Catulo, ele foi sem dúvida um grande homem, instruído no conhecimento de numerosas e importantes artes, encontrou muitas soluções poéticas com sutileza, muitas com gravidade, escreveu não poucos poemas no estilo romano, mas eu julgava que, embora seus escritos devessem muito a Catulo, Catulo devia pouco a seus escritos. Se quisermos avaliar cuidadosamente sua obra, pondo de lado a reverência escrupulosa com que a Antigüidade nos mantém constrangidos e embaraçados, talvez não sintas saudade de nada que diga respeito à agudeza de espírito ou à pureza da linguagem, e não entendas por que não possam existir novos poemas.

4. Já Marco Valério Marcial, assim como se seguiu a Catulo após um longo intervalo de tempo, na mesma medida o deixou para trás, completamente vencido e superado em todos os aspectos do talento. A respeito de Marcial julgo o seguinte: são magníficas e admiráveis as qualidades desse homem nesse gênero, mas elas não são capazes de abater a dedicação ou desencorajar a tentativa de outros.

5. Claudiano, muito inferior em glória, que granjeara a partir dos dois Panegíricos, não satisfeito, aspirou também a esta outra, da qual, na minha opinião, não alcançou nem sequer a sombra.

6. Tanto nossa época quanto a dos antepassados forneceram um excessivo número de escritores que não careceram nem do louvor do talento, nem do encanto da inovação. 
7. Esse encanto, embora não possa ou, pelo menos, não deva faltar-me, convém que seja desejável sob a condição de que, se não for referendado por nenhum mérito de talento, nem de dedicação, nem de capacidade de expressão, eu declare que não venha a ter nenhum valor.

8. Para mim, sem dúvida será algo plenamente satisfatório se leres esta obra de tal modo que a compreendas, a compreenderes de tal modo que a julgues, a julgares de tal modo que não faças a menor concessão aos erros, nem admitas que as qualidades, que percebo quanto são limitadas, sejam privadas de seus frutos. Graças a essa tua crítica, no futuro serei, ou porque inteiramente dissuadido, ou ao menos desencorajado, um pouco mais cauteloso para escrever. Adeus. Lyon, 29 de abril. 


\title{
de \\ ANTÔNIO DE GOUVEIA, POETA PORTUGUÊS
}

\author{
PRIMEIRO LIVRO \\ DE EPIGRAMAS
}

[1]

PARA CATHERINE DE BEAUFFREMONT

Assume, Catherine, o patrocínio de meu livrinho,

Que, juntamente com o seu senhor, deseja ardentemente ser teu.

O que antes não dei, Catherine, agora será possível dar.

Bem sabes que não tenho nenhum direito sobre este senhor.

[2]

\section{PARA MEU LIVRINHO}

Se acaso alguém te acusar de seres novo, Livrinho,

E te lançar de imediato para longe das mãos,

Se for lícito e conveniente, diz-lhe tu o seguinte: "Ora, ora, Amigo

Leitor, acaso os antigos não foram novos?" 


\section{PARA MEU IRMÃO ANDRÉ DE GOUVEIA}

Observas com admiração o que escrevo sem talento,

Nem um pouco perturbado pela inveja.

Meu irmão, embora sem talento,

Este não é um livro perturbado pela inveja.

[4]

\section{PARA AUSÔNIO}

Desde que a norma dos antigos costumes seja respeitada por ti,

Dizes, que a Musa sóbria brinque com gracejos mistos.

Mas, embora a norma dos antigos costumes não tenha, para mim, nenhum valor,

Minha obra evitará os gracejos indecentes.

Pois terá sido suficiente, a quem se cala, ter vivido honestamente.

A quem escreve não basta que a vida seja casta.

[5]

EM MEMÓRIA DE JEAN D’YBERROLA

Neste túmulo exíguo está enterrado Yberrola,

Em quem a Fortuna, a Ciência e a Virtude rivalizaram.

Mas, entre os vivos, a Fortuna, a Ciência e a Virtude

Mantêm um nome que em tempo nenhum vai perecer.

Se perguntas por que não foram sepultadas juntamente com ele,

É que, num túmulo tão exíguo, não puderam ser contidas. 
[6]

SOBRE A PEGA DO PICARDO JEAN LACROIX

Uma pega barulhenta é o interesse de Lacroix: pois ele diz

Que "Picardia" vem de "pega"; mas ele está inteiramente enganado.

Eu tendo a acreditar que esse nome provém do nome do picanço:

De fato, é um povo marcial: e o picanço é a ave de Marte.

[7]

\section{EM MEMÓRIA DE HUBERT}

Acreditou Hubert que não há uma segunda vida:

E não estabeleceu nenhum limite aos seus vícios.

Oh! Que mente conhecedora do pecado, que profetisa do futuro!

Eterna foi a morte dada aos vícios de Hubert.

[8]

\section{PARA OS AMIGOS}

Por que, em meus versos, não se mencionam os vossos nomes, amigos?

Quem poderia não se lembrar de si mesmo?

Não foi esse o motivo, acreditai-me: na verdade,

Não quero que os vossos nomes desapareçam junto com minhas páginas.

[9]

EM MEMÓRIA DE LUCILA

Versão de um antiqüíssimo poema grego

Neste túmulo, Lucila, jazes tu, que pariste gêmeos.

Um sobrevive ao pai; o outro é teu companheiro. 
Se não me deves nada, pergunto-te: por que pagas o não-devido,

Fazendo-te, por tua própria vontade, meu devedor?

O que posso dizer que é isso, senão que queres ser devedor,

Para que possas deste modo ser credor?

\section{BARLANDO}

Até as bocas do Tártaro Plutão arrastou Barlando,

Embora os deuses e as deusas do inferno tenham se oposto:

Mas como não encontrou nenhum castigo para os seus vícios,

Ordenou que fosse rapidamente embora dos lugares infernais,

Temendo que ele, que havia conspurcado toda a terra,

Não diferente da terra, poluísse o Tártaro.

PARA CATHERINE DE BEAUFFREMONT

Versão de um poema em francês de Clément Marot

Catherine me atingiu com uma neve candente: eu pensava

Que a neve não tinha fogo; a neve, no entanto, era fogo.

Não é uma credulidade vã, não é uma experiência enganosa:

Senti de verdade o coração queimado por uma súbita brasa.

Assim, onde estarei seguro, se o ardor se esconde na neve,

Onde escaparei das tuas tochas, cruel Cupido?

$\mathrm{Tu}$, Catherine, podes apagar estas súbitas chamas,

Não com gelo, ou neve, ou água cristalina,

Mas na medida em que a causadora do meu tormento também sentir o que sofro,

E cada um de nós arder com uma chama igual. 


\section{PARA SUSSANNÉE}

Então concordas que existem quatro "Virgílios" franceses,

$E$ te incluis entre esses quatro.

Com certeza és um sujeito maluco, ou a França é estéril, se ela,

Para ter quatro poetas, te inclui.

\section{PARA PINASSE}

Tu tens, Pinasse, um burro que nunca pastou nem capim

Nem a gorda aveia: mas, apesar disso, ele é gordo.

Perguntas qual é o motivo? Ele aprendeu a viver assim com pouco:

Nessas questões a convivência tem muito peso.

[15]

\section{PARA MARCIS}

Invocas Maria com sussurros roucos e incessantes,

E num segundo ruminas, velho senhor, mil ave-marias.

Em seguida, prometes a ti mesmo as recompensas de uma vida feliz

E, livre de preocupações, aguardas o dia da tua morte.

Oh, como uma falsa imagem da virtude te engana!

Deus não julga que rezar seja mexer os lábios.

[16]

\section{BRIAND DE LA VALLÉE}

Quando troveja, Vallée foge com pés assustados para o fundo da adega;

Ele não pensa que exista deus na adega. 


\section{O AMOR FERIDO}

Versão de um poema em grego de Teócrito

Quando o filho de Vênus colhia, ao acaso, mel,

Uma abelha agressiva picou-o na ponta do dedo.

O Amor grita, e fere a terra, e tenta superar a dor

Ardente com um sopro frio.

Assim gemendo vai até Vênus, a quem diz: "Olha, mãe,

A grande ferida de uma minúscula abelha."

A mãe lhe respondeu: “A tua força é idêntica, filho, pois

Com uma mão pequenina provocas feridas terríveis."

[18]

\section{PARA DIOGO DE TEIVE}

Encontrar uma refeição escondida dentro da cozinha:

Teive diz que isso não pode ter sido feito por um sujeito sem inteligência.

Encontrar uma refeição escondida, Teive, na cozinha,

Julgo valer pelo nariz, julgo não depender do cérebro.

[19]

PARA BARENO CICERONIANO

O fato de chamares Netuno de pai do Estige,

E escreveres isso em tuas notinhas,

Creio ser um chiste à maneira de Túlio. 
Destruição do vinhedo, um bode é imolado, como vítima expiatória, Ao deus Baco, diante do altar, para purgar o sacrilégio.

Então, Zébédée, serás sacrificado diante do altar de Baco:

Pois o bode costuma ficar mais macio com vinho.

Quem quis que tu tivesses o nome de uma cidade tão importante,

Cachorrinho, minha alegria,

Achou por bem indicar teu valor e tua esperteza

Com um nome tão importante.

Este cão tem por nome Ribaud, meu amor e divertimento,

Cuidado, trabalho, dedicação, minha alegria:

Cão de focinho grande, pêlo malhado, pescoço

Fino e um pouco comprido, corpo e orelha curtos:

A perna lhe sobe de um pé arqueado,

A barba inferior é marcada por três pêlos:

Do lombo largo se estende uma cauda fina.

Tira-lhe o nome, não vês no cão nada de torpe. 


\section{PARA CATHERINE DE BEAUFFREMONT}

Que não haja nenhuma mulher, nenhuma, que se iguale a ti,

Pela virtude, profunda sabedoria, antiga nobreza,

Nada espantoso: o que te foi atribuído por deuses supremos,

Quem, Catherine, pode sequer pretender ou tomar?

\section{PARA MÁXIMO}

A ti, que estavas com o dente doendo e procuravas um remédio certeiro,

As velhinhas te aconselharam a beber.

Máximo, é de temer que esse conselho talvez te faça mal:

Pois vais querer que esta dor volte com mais freqüência.

\section{[25]}

\section{PARA JEAN DE BORDA}

Admito que minhas lembrancinhas são superadas por teus presentes.

E não perguntes em que proporção: basta serem meus.

Mas os teus, porque são teus - que mais posso dizer?

Mas essas minhas lembrancinhas, superadas por ti, absolutamente

[todos dizem superar.

Então, Borda, talvez possas dizer quanto tu me superas,

Embora não sejas capaz de muito. 


\section{VÊNUS}

Versão de um poema em francês de Antoine Alaigre

Viu-me nua Páris, e nua me viu Adônis,

Um, meu juiz, o outro, meu amor.

Mas, Apeles? Quando me teria visto nua Apeles de Rodes?

Mentira! Ele teria visto, por certo, uma Deusa!

Contudo, quem me pintou assim à perfeição, é preciso

Que tenha visto Vênus nua também ele!

\section{PARA SALMON MACRIN}

Rivalizas com três poetas latinos, Macrin,

E fazes isso na lira, nos chistes e nos versos plangentes.

Não é em vão que praticas muitos gêneros de modo excelente: mas um único

Hércules dificilmente é capaz de sobrepujar dois.

[28]

\section{PARA JEAN LACROIX}

Marcial, por seus argutos livros de epigramas

Conhecido em todo o mundo,

Tu perguntas quem foi, e negas que tenha sido,

Apesar dos poemas argutos por todas e todas as páginas,

Um homem conhecido nos extremos da terra.

Acusas de ser uma mentira clara, e sustentas isso:

Só não sabes que esse recurso é hispânico. 


\section{O REI E O MARINHEIRO}

Um marinheiro transportava o rei por mares adversos,

E, ao mesmo tempo, chorava o pai, afogado nas águas revoltas.

Diante disso, o rei lhe disse: "Que tamanha loucura te moveu, tolo,

Para que ousasses dar velas ao mar infiel?"

O piloto lhe respondeu: "Por que te entregas, ótimo rei,

Ao leito macio onde sabes que teu pai morreu?"

[30]

\section{PARA MEDIANO}

Retardas, Mediano, a marcha justa do Evangelho,

E cobres a lamparina acesa com um vaso de um alqueire.

Qual é o motivo? É para que, fazendo o contrário, não sejas porventura notado. Assim o ladrão, Mediano, costuma odiar o dia.

\section{O ASNO}

Um noivo convidou para o banquete um asno velho,

Que já não tinha um pingo de vigor em todo o corpo.

Este envia em seu lugar um filho crescido, e ensina

$\mathrm{O}$ que ele deve fazer e de que modo:

"Entra no palácio com certa majestade:

Retira as patas dos lugares proibidos.

Caso eles comam, dancem, cantem, faz tudo isso, filho,

Para não pareceres de comportamento grosseiro.”

O filho perguntou ao velho: "Caso eles fodam, que faço?" "Avisa-me disso

E num instante", disse o asno, "estarei lá". 
VERSÃO DE UM POEMA EM FRANCÊS DE JACQUES DE BEAUNE

Por acaso a um lugar repleto de horrores e medos numerosos chegam

A Morte e o Amor de asas ligeiras.

Em pânico, a Morte toma nas mãos

As armas ardentes do Cupido, e o Menino, os dardos gelados da Morte.

É por isso que a praga assim nascida se prolongou até nossos dias:

É por isso que um velho ama, é por isso que morre todo amante.

\section{O MONGE}

"Aprendizei", diz o monge ao povo, trovejando as palavras:

"Deus começou fazenzendo antes de 'ns'nar."

Ele, embora ignorante, quando percebe que errou de modo vergonhoso,

Para justificar o engano, diz:

Se estendo as palavras breves, se reduzo as longas,

E nem todas as sílabas respeitam sua duração,

Não há nada de espantoso, pois se diz que por trinta anos

Ele cumpriu as leis do Pai, e instruiu os ignorantes em três.

OS IRMÃOS CHARLES E CRISTOPHE CANDELEY

Igual virtude e igual nobreza ornam o nobre par de irmãos,

Beleza também igual exalta um e outro.

Igual ainda, mas muito maior com os anos, é a inteligência:

A deusa cega não quis ser menor para eles.

Se tudo isso não tivesse sido dado em proporções iguais, em todos os aspectos,

O que de maior o próprio Júpiter podia dar? 


\section{A JOVEM CASTA}

Como Fúrio queria beijar a jovem,

Ela dá um tapa em seu rosto.

E disse: "Vai, crava beijos crepitantes na mão!"

Pois, no fundo, a mão e a boca são a mesma carne.

[36]

\section{PARA CATHERINE DE BEAUFFREMONT}

Se a ti, e a teus cabelos dourados, e olhos brilhantes,

E lábios mais vívidos do que rosas purpúreas,

Se a esta beleza rara, se à divina perfeição do teu rosto

(Que eu não pareça estar afirmando algo por acaso exagerado)

E ao teu andar majestoso, que eu podia jurar ser igual ao de deusas,

Se ao teu encanto irresistível, que é companheiro de tuas virtudes,

Se à nobreza que foi legada por teus avós e bisavós,

Que pôde ser engrandecida por teus méritos,

Se a tudo isso admiro e amo, que influência se deve ao amor?

Faz, pois, com que eu, ainda que não queira, seja obrigado

[a amar.

Por que não te elogio, creio, Dolet, que perguntas.

Isso tu fazes melhor do que eu. 


\section{O MONGE}

Os ladrões ordenaram a um monge, preso no meio do bosque,

Que falasse sobre a religião cristã.

Ele obedece bem rápido à ordem, e nem, de fato, era conveniente dizer o

[contrário,

E dizem que falou desse modo:

Um bando de jovens foi arrastado pelos perigos de terra e mar,

É este o caminho que segues, é este que leva aos céus.

Com efeito, Cristo vagava por terra e mar, e conta-se que

Não passava muito tempo num mesmo lugar.

Tu também, ora para lá, ora para cá, corres a esmo,

E uma mesma hora não te vê num mesmo lugar.

Ele não lavrava a terra solta com o curvo arado,

Nem costumava semear a terra:

Vivia, porém, e nunca lhe faltou nada para viver:

Vós sois iguais a ele também nessa capacidade.

Que mais? Finalmente ele foi arrastado aos bancos dos tribunais,

E condenado: o mesmo destino vos está reservado.

Ele, crucificado, derramou a vida junto com o sangue:

Vós não estareis, acredito, em melhor situação.

Ele visita as casas das almas, e a morada da noite cega,

E vós deveis trilhar esse mesmo caminho.

Ele, porém, em pouco tempo tornou a ver os reinos celestes:

Não será dado, a vós, voltar de lá. 
Ganhei, meu irmão, uma lebre: ela é servida a ti: acaso

Não é isso, realmente, ganhar e perder uma lebre?

[40]

\section{PARA CATHERINE DE BEAUFFREMONT}

Perdoa-me se admiro o que sou obrigado a admirar,

E amo, esquecido dos meus deveres.

Também tu farás isso: pois ninguém é capaz de dizer

Se és deusa ou mulher.

PARA O VENDEDOR DE NINHARIAS

Se continuas a vender tão caro ninharias de nenhum valor,

Todos terão esse interesse e esse mesmo negócio.

Assim a tua atividade e o lucro da tua atividade em pouco tempo perderão o

[valor.

Por isso, será melhor para ti: vende mais barato!

[42]

PARA PRAGMÃO

Destróis, edificas, e de novo, num vaivém, e mudas tudo por completo,

E não deixas, Pragmão, nada quieto no seu devido lugar.

Creio que queres que os mais jovens digam que nunca fizeste nada.

Mas eles dirão: Era ele quem fazia tudo... 
Uma multidão de crentes se esforçava para tocar Tomás

E arrancar os pêlos do asno que o transportava.

Então uma velha avança sobre as cãs e o raro cabelo de Tomás,

E com uma unha rápida belisca o Velho.

Tomás gritou. A velha, surpresa, disse: “Que foi?

Acaso não é permitido a qualquer um arrancar os pêlos do burro?"

\section{PARA JACQUES D'ALEIN}

O que minha obra nunca mereceu, Jacques,

O que, ademais, eu julgo não ter feito por merecer, por meus serviços,

Tu dás para mim; é um erro. Mas possas tu dizer que, na verdade,

O que, para mim, é mais do que satisfatório, não é satisfatório para ti

\section{PIMPINO}

Enquanto Pimpino sulcava o imenso oceano com um barco,

Eis que súbito o Euro agita as águas do mar.

A cada um aterroriza a própria morte, a cada um os perigos,

E é doloroso, na visão de cada um, servir de comida a peixes vorazes.

Neste momento, Pimpino diz: "Para todos vós, amigos, é a morte

O motivo do temor, mas, para mim, são as gélidas águas.

De fato, se o poder divino transformasse o mar em vinho,

Aqui eu gostaria que fosse o túmulo do meu corpo." 
Sou chamado por ti, Máximo, sempre, de importuno,

Quando peço esse teu queijo.

O que queres? Ou dá o queijinho, Máximo, todo,

Ou não me culpes pelo que tu fazes.

Preferes, Alfasiano, a retórica à culinária:

Tomara que te julguem quase entre os piores cozinheiros.

Por que digo isso? É porque queres ser considerado melhor

Orador do que és, Alfasiano, cozinheiro...

Livros de Inscrições, não de Epigramas,

É como intitulas a Amazônia das tuas bobagens.

Erras grosseiramente: são livros de Escrevinhações.

[49]

PARA CATHERINE DE BEAUFFREMONT

Só me darei, como um presente, a ti, Catherine, de bom grado,

Depois que me tiveres devolvido a mim. 


\section{PARA JEAN LACROIX}

Com freqüência me dizes, é uma coisa importante ser um patrono:

Não é nada, digo-te eu com mais frequiência.

De fato, que razão há para isso? Então, se uma mente sensata voltasse para a [terra,

Não poderia ter na terra nenhum lugar?

\section{O ARTESÃO}

Havia um carvalho estéril, imenso, no meio do campo,

Um carvalho, o maior desvelo de Júpiter Olímpico.

Um artesão quis que ele fosse um deus: fez um Priapo

E colocou a própria obra num altar sagrado.

Quando uma multidão levava suas oferendas ao novo deus, e ao mesmo tempo

$\mathrm{O}$ artesão em pessoa fazia as preces costumeiras,

Eis que do altar elevado o deus caiu e, com uma pancada

Terrível, rachou a cabeça, justamente, do artesão.

Ele, à beira da morte, interrompeu os amigos, e, com dificuldade,

Por meio de sons entrecortados, contam que falou assim:

"Aprendei por este exemplo a cunhar novas divindades: o Carvalho

Tornou-se pior, quando se tornou um deus."

PARA JEAN DUPUY

Tu portas dádivas maiores que teu corpo, meu pequeno Dupuy.

Quem acreditaria que tu farias parelha a tão grande peso?

Quem? Só mesmo quem sabia que tu tens um espírito

Muito maior do que teu corpo e teus dons. 


\section{PARA CATHERINE DE BEAUFFREMONT}

Se, com muita freqüência, titubeia a mão, a mim, desejoso de prosseguir [com o elogio aos méritos dos teus,

E aos teus méritos, Catherine,

A culpa é tua, se alguma culpa pode haver numa deusa:

Arrebatas toda a inspiração ao teu poeta.

[54]

EM MEMÓRIA DO MÉDICO GABRIEL DE TARREGA

Vira, e podia ter evitado a morte iminente

Tarrega: mas, com certeza, ele preferiu morrer.

Ele preferiu morrer, para poder viver melhor

Nas alturas. A Medicina não serve em nada a um médico?

[55]

PARA ÉTIENNE DOLET

Se teus poemas têm a alma de Cícero, decerto

Tu podes ter também.

[56]

PARA CATHERINE DE BEAUFFREMONT

Que tu és a primeira em toda espécie de virtude! Por favor,

Quem pode dizer isso, se não há nenhuma mulher em segundo lugar,

[perto de ti? 
Quanto aos encantos, melodia e floreios de Isócrates,

Leitor, se não consigo imitá-los perfeitamente,

Todavia, sua imensa qualidade talvez não possa transparecer melhor

Do que pela comparação com as minhas limitações.

[58]

\section{PARA FRANCISCO I, REI DA FRANÇA}

Versão de um poema em francês de Mellin de Saint-Gelais

Caso a bondade queira ser melhor, caso a popularidade mais popular,

E a prosperidade se tornar mais próspera,

A inteligência mais inteligente, e a própria perfeição

Ser levada à perfeição, e aos seus valores exatos acrescentar muitos,

A ti, Rei, deverão implorar, para que permitas

Que elas sejam colocadas entre os teus títulos:

E para que estejas disposto a seres chamado, pela boca dos descendentes,

De bom, popular, feliz, inteligente e perfeito, tal e qual és.

PARA ZÉBÉDÉE

Nem os comentários das pessoas, nem os decretos do Senado,

Nada consegue fazer com que cortes a barba.

Não quero um homem que procura, graças à barba, se fazer nobre:

Quero aquele que pode enobrecer a barba. 


\section{PARA BOURBON}

Se queres obter para ti o sagrado nome de poeta,

Bourbon, com versinhos ligeiros,

A ti nós, uma turba rústica e profana,

Que fazemos versinhos que valem menos do que um asse,

A ti nós vamos considerar de um asse?

[61]

\section{PARA O ARQUIPOETA}

Depois que tiveres tomado consciência de que o grande Virgílio escreveu,

Tu mal chegarás a ser, na tua própria opinião, um semipoeta ruim.

[62]

EM MEMÓRIA DE LAURA

Lendo os divinos poemas de Petrarca, Febo diz:

"Este é um loureiro; que seja apenas Laura, é o que se permite!"

Disse, e atravessou o seu inocente flanco com um ferimento letal,

Dizendo: "Despreza, Laura, um Deus!"

Laura, morrendo, diz: "Eu amo Febo:

Meu erro foi ter agradado a um Deus." 
[63]

A RESPOSTA DO AMOR

Versão de um poema em francês de Albenas

O Amor, ostentando fisionomia e toga de doutor,

Tratava, em plena praça, de assuntos da maior grandeza.

A ele eu perguntei: "Por Vênus, diz-me, por que a dor acompanha o amor?"

Ele me respondeu: "Sozinho, o amor seria a morte."

[64]

PARA O LEITOR

Há uns maus, há alguns piores, e péssimos a maioria.

A minha obra revela seu autor.

FIM DO LIVRO PRIMEIRO 


\section{SEGUNDO LIVRO}

\section{$\mathrm{DE}$ \\ EPIGRAMAS}

[1]

PARA CATHERINE DE BEAUFFREMONT

Se, Catherine, minha obra adotou teu nome

E se entregou ao teu patrocínio,

Nada de admirar: ela, que foi digna, possivelmente, de perecer,

Pensa que pode viver graças a tal protetora.

[2]

\section{PARA O LEITOR}

Folheia, leitor, por gentileza, este segundo livro

Das minhas bobagens, que apresento a ti.

Acrescentarei um terceiro, desde que seja do teu agrado,

Pois o que temos em mãos de bobagens, leitor,

É o suficiente para um terceiro e até um quarto livro. 


\section{A PALIDEZ DA DONZELA}

Versão de um poema em francês de Antoine Alaigre

O Amor instalara sua praça-de-guerra no coração descuidado da jovem:

E era duro demais num peito delicado.

E, dado o fato de sofreres mais, o Menino, feroz - ai! - em demasia, e

[sangüinário,

Absorve toda a vida do seu corpo.

Então o coração, quando sentiu as forças abatidas, convocou,

Como tropa auxiliar, a retaguarda de sangue da sua face vermelha.

[4]

\section{CUPIDO ENGANADO}

A estrangeira Gelasina foi ao encontro do Amor vendado,

E o Menino se pôs a dizer: “Olá, Mãe!”

Ela nada respondeu. Mas, subitamente retirada a venda

Dos olhos, um sentimento de vergonha se espalha pelo rosto do Menino.

“Ah! Não te envergonhes do erro, Cupido vendado!

Olhos abertos também se enganaram do mesmo modo."

[5]

\section{A OBRA DE FRANÇOIS VALERIOLA}

Uma obra digna de ser lida por uma posteridade muito tardia

Valeriola completou, na medida exata.

Apenas lê a obra até o fim, e admirarás o autor:

Conhecerás o autor, será dado maior valor pela obra.

É desnecessário, portanto, minha recomendação avançar: a obra louva

O seu autor; e o autor louva a obra. 


\section{EM MEMÓRIA DO ADVOGADO MONTAGNE}

Montagne resgatava, das garras da morte, os réus temerosos,

Graças ao poder de sua eloqüência e discernimento.

A Morte clamava que seu reino tinha sucumbido, Caronte, seu ganho,

E as inclementes Irmãs, seus poderes.

Sem demora, arrebatam Montagne, sem direito algum.

$\mathrm{Ah}$, não foi assim que ele livrou os réus da morte!

\section{PARA JACQUES DE BEAUNE}

Quando enumeras os poetas que o nosso tempo produziu,

$\mathrm{Na}$ lista dos poetas acertadamente me incluis, Jacques.

Mas se queres pesar os poetas com uma balança justa,

Não serei eu, crê em mim, digno deste peso.

[8]

PARA MELLIN DE SAINT-GELAIS

Confio a ti, Saint-Gelais, os meus livrinhos,

Livrinhos de brevidade singular.

Embora curtinhos, verás que contêm

Todo gênero de bobagens.

[9]

PARA O LEITOR

Os epigramas que ofereço são poucos, admito, mas são mal feitos, leitor:

Por isso podes dizer, com toda a razão, que são muitos, em excesso. 
Se não há nada engraçado nos teus livrinhos,

Dolet, tu não tens culpa nenhuma:

Por mais e mais que te esforçasses todo

Para que te tornasses um escritor constantemente engraçado,

Esse teu rosto inflexível, ameaçador, severo,

Rosto insensível, rosto tétrico, rosto catoniano,

Afugenta os chistes e gracejos romanos.

Se a Morte tivesse acreditado na existência posterior

De um inimigo das injustiças semelhante a Ciret,

Nem à pátria, à esposa, aos filhos, nem às próprias leis

Teria feito esta injustiça.

\section{VERSÃO DE UM POEMA EM FRANCÊS DE MAROT}

O Corpo procura ajuda médica; a Mente, completamente ao contrário,

Deseja com ardor ir embora, livre dos negros cárceres.

O Corpo admira a terra, a Mente, etérea, os astros, dos quais é afim.

Deuses, com que brados assustadores a Mente e a Carne discutem!?

"Eu?" - diz o Corpo - "Sucumbir assim a uma doença grave?"

A Mente, ao contrário, retruca: "Deter-me sempre com delongas

[detestáveis?"

"Vai!" - diz a Carne - "Eu almejo o melhor." A ela o Espírito diz:

"Erramos um e outro: fiquemos ao arbítrio de Deus." 


\section{DE CATHERINE DE BEAUFFREMONT PARA LAURA}

Pára, por favor, de desprezar a Musa de meu Gouveia,

Ó Laura, excessivamente orgulhosa do teu Petrarca.

Acredita-me, quanto mais o facundo Petrarca escreve,

Tanto mais se distancia do amor a sua mente.

A quem o Amor não rouba furtivamente do corpo a inteligência,

O discernimento? A quem ele permite lembrar de si próprio?

Por isso, acabarás por aceitar que o meu poeta não foi inferior a

[Petrarca, em talento,

Mas apenas amou mais que o teu.

PARA D. JOÃO III, REI DE PORTUGAL

Uma vez que a ti não faltam nem forças, nem recursos para as batalhas,

E a sorte da guerra se dá e está ao teu arbítrio,

Por que não atacas os povos vizinhos a fogo e ferro?

Por que não praticas uma justiça injusta, a teu favor, por toda parte?

Esta é a tua divina e inteiramente régia virtude:

Poder destruir, certamente; não querer destruir, porém.

[15]

PARA JACQUES DE BEAUNE

Eu fui levado a dissimular minha pátria: mas, de fato,

Não quero que a pátria viva em meus poemas.

Ademais, sua luz é tão grande, tão grande a glória,

Que ela reluz nas trevas com seu próprio luzir. 
PARA O ARQUIPOETA

Do conjunto dos poetas subtrairás todos os poetas:

Desse modo num instante te tornarás o Arquipoeta.

[17]

\section{A INVEJA DAS DEUSAS}

Viram-te, Catherine, e invejaram a ti, uma jovem,

Três deusas, Juno, Palas e a graciosa Vênus.

Assim revoltadas e bradando terrivelmente,

Elas se ajoelharam diante de Júpiter.

Então Juno, diante das outras, falou, em meio à dor,

Com a voz trêmula pelos suspiros convulsos:

Juno compartilha suas riquezas, Juno compartilha suas honrarias?

Mentira! Juno pode tomá-las dos mortais!

Depois Vênus: Ó Pai, Vênus, que venceu as deusas no Ida,

Como pôde agora Vênus ser vencida pela beleza de uma mortal?

Enquanto Palas: Por que foi necessário que eu tivesse nascido do teu cérebro,

Se uma mulher e um homem podem gerar uma Palas?

Júpiter, nesse ponto: Tais pais não puderam gerar uma mulher diferente:

Todavia, não geraram uma deusa.

\section{PARA BOURBON}

Quanto mais vezes te chamo de poeta

Por causa de teus versinhos, tanto mais e mais,

Bourbon, duvido que versinhos ligeiros

Não possam produzir um poeta sério. 


\section{PARA O LEITOR}

Ó leitor interessado, eu digo para o meu livrinho: "Cresce!"

Mas ele me responde: "Por Hércules, pai, tu não estás sendo sensato."

Quando pergunto o motivo, ele diz o seguinte, rindo:

"Se eu, sendo um livrinho, agrado, tu esperas que eu possa agradar,

[como livro?"

[20]

\section{PARA VIRGÍLIO}

Não te espantes, Virgílio, com o motivo pelo qual tem sido chamado

[de Arquipoeta

Um sujeito qualquer: eu conheço a verdadeira razão.

Quanto distas, douto Virgílio, dos piores poetas,

Tanto dista deles o meu Arquipoeta.

Pois quanto estás à frente, douto Virgílio, dos piores poetas,

Tanto para trás está o meu Arquipoeta.

[21]

PARA CATHERINE DE BEAUFFREMONT

Se, Catherine, és considerada igual a Laura,

Que o genial poeta tornou tão grande,

És bem capaz de ser maior do que a própria Laura

Tanto quanto o poeta Petrarca era maior do que eu. 
Agora já podes ficar contente com a tua sorte, Póstumo,

Depois de teres sido agraciado com duas filhas.

Pois se não desejavas nem metade de uma,

Recebeste mais do que desejavas, Póstumo.

[23]

\section{PARA ÉTIENNE DOLET}

Se Pitágoras, ó Dolet, defende a doutrina do renascimento,

Não é de espantar, supondo que tens a alma de Cícero.

Mas, dispersa por tão grande corpo e por tão compridos membros,

Certamente ela perdeu o seu valor.

\section{EM MEMÓRIA DE SIBYLLE BARCY}

Quando o próprio Pai dos homens se prepara para levar aos céus

Tanto o espírito de Sibila, quanto a prisão terrena do seu espírito,

Eis que a Terra, lançando os braços ao colo da filha, rodeando-a

Diz: "Entrega a alma ao pai, o corpo à mãe!"

A filha, com pena das justas lágrimas da piedosa mãe,

Deixou no seio materno um corpo sem vida. 


\section{PARA OS POETAS FRANCESES}

Ó sagrados poetas, corações diletos a Febo,

Ninguém pense que meus sarcasmos estão sendo distribuídos

[gratuitamente.

Não tenho nem mão generosa nem uma grande fortuna. E então?

É para dar lucro, ó poetas, que distribuo meus sarcasmos.

[26]

\section{PARA ANTOINE ARLIER}

Tão grande, Arlier, é a tua seriedade, tão grande a tua inteligência,

Quanto podem do céu ser dadas a um homem.

Tão grande é a tua sabedoria acumulada sobre variados assuntos,

Quanto um longo tempo e o esforço costumam produzir.

Elas prescrevem tudo o que tu aprovaste, ainda que eu considere uma

[blasfêmia,

Seja condenar alguém, seja não aprová-lo inteiramente.

Mas quando, Arlier, meus devaneios são aprovados por ti,

Será que estás enganado em teu julgamento?

Ou, ao contrário (e, de fato, tamanha blasfêmia não sairá da minha boca),

O teu julgamento é verdadeiro, e a tua língua sensata?

[27]

\section{PARA JAN HABERT}

Os epigramas que tu julgas poucos, Jan, eu julgaria,

Se bons, muitos, na medida; se maus, muitos, em excesso. 
Ganhas de mim em talento, encanto, beleza,

Ganhas em nobreza, ganhas em todo

Gênero de todas as mais importantes qualidades:

Ganhas, não nego, nem posso negar.

Mas meu amor e minha fidelidade não sabem

Perder: e sozinhos movem uma rebelião.

\section{LORENZO VALLA}

Por juramento Valla haveria de corrigir

Uma e outra Minerva, se tivesse podido.

Que fazer? Que ele enfrente a Minerva latina e a grega.

Mas não pôde fazê-lo bem: então teve de fazê-lo mal.

[30]

\section{EM MEMÓRIA DE JEAN ALBERT}

Não te espantes, viajante, com o pequenino túmulo de Albert:

Pois seja qual for o túmulo com que

Albert pôde ser abrigado, também puderam ser abrigadas as sábias Irmãs,

As Graças e a Piedade. 
Com frequência costumas perguntar o que penso a teu respeito, se elogio

Os dons da tua virtude ou do teu talento.

A cabeça é oca, a mente ímpia, a língua insolente,

As mãos especialistas e rápidas em cometer crimes de toda espécie.

A tua boca é imensa, uma porta imunda de um horrível estômago,

Mais repugnante e fétida que teu cu.

As pernas e os pés, pilares de dolo, estupro e furto.

Por acaso agora consegues saber o que penso a teu respeito?

\section{PARA GILBERT}

Queres, Gilbert, me agradar com teus presentes e com tua atenção:

E queres que eu colha a messe que plantei.

Mas receio que faças muitos agrados, Gilbert:

É que tu pensas que tua virtude não é suficiente para me agradar.

\section{PARA CATHERINE DE BEAUFFREMONT}

Assim que te vi, pela primeira vez, por dádiva dos deuses poderosos,

Tu tentavas me esconder teu nome.

Mas o Amor, subitamente compadecido do apaixonado,

Puxou minha orelha e me contou, ele próprio, teu nome.

Parei totalmente perplexo, preso num longo olhar contemplativo,

Como que desiludido, mas mantive minha confiança.

"Por que duvidas?" - disse ele. - "Acredita no deus, ímpio, acredita!"

A ele eu respondi: "Acreditar que uma deusa tem nome de mulher?" 
BASSA

Muitas vezes se perguntou a Bassa o motivo por que

Não pagava a um padre para fazer orações pela alma do marido.

Bassa dizia: "Meu marido não precisa de oração nenhuma,

Seja se for profundamente feliz, seja se eternamente desgraçado.”

"Mas então, se ele for purificado, por pouco tempo, no fogo abrasador,

Por que não?" "Então eu farei com que ele saia de lá, com

[umas poucas orações pagas por mim?

Justamente de lá, onde, suando, finalmente está eliminando de sua íntimas

Entranhas o terrível veneno do mal-gálico?"

\section{PARA SUSSANNÉE}

O escazonte pelo qual me elogias dessa tal maneira, poeta,

Não respeita a métrica dos iambos

Nem segue a regra dos escazontes. Portanto,

Quando, uma única vez, pensavas escrever um escazonte,

Nem sequer uma vez sai um escazonte de um poeta manco.

PARA ZÉBÉDÉE

À noite, em minha casa, Zébédée, contas o que se passa na cidade,

E queres que te sejam oferecidos os melhores vinhos pelos teus

[versinhos.

Logo, logo vai faltar vinho para os criados servirem,

Pois, se declamas muitos versinhos, mais ainda, Zébédée, bebes. 


\section{PARA O LEITOR DA MINHA TRADUÇÃO DO FAMOSO DISCURSO EM DEFESA DE CTESIFONTE}

Toma como exemplo, posteridade, para que te acauteles,

Os crimes que cometi, temerário, numa única tradução.

Aniquilei o vigor da eloqüência com uma enxurrada fria,

Coloquei vinhos excelentes em barris podres.

E para que julgues mais grave o crime, ele, que fora vencedor em Atenas,

Hoje sai derrotado por causa das minhas limitações.

\section{EM MEMÓRIA DE FRANCESCA PERUSIA}

Para Vênus

Diante do fato de que Francesca Perusia foi arrebatada na flor da idade,

Por que tu e teu filho chorastes?

Por que chorastes, se o tempo nada podia acrescentar

À jovem em termos de beleza, virtude ou talento?

\section{PARA CATHERINE DE BEAUFFREMONT}

Caso minha obra possa viver, Catherine,

E ser lida, afinal, por uma posteridade tardia,

É em grande parte graças a ti: visto que tu, tão merecedora da melhor Camena,

Consentiste em ser lida em meu poema.

O que a afortunada Laura deve ao genial Petrarca,

Deva, afinal, minha página a ti. 
Eis que, de repente, a fecunda França produz, numa única geração,

Dolet, ferino no iambo;

Macrin, que sabe aplacar, com a curva lira,

As ameaças ardentes dos Deuses;

Bourbon, fluente nos chistes e gracejos latinos,

Famoso por seus versinhos sérios;

E vós, ó Visagier, Brice, Sainte-Marthe, Ducher,

Esplendores da sagrada Poesia.

Perguntas o que faço? Enumero, Beaune, os poetas

Que a fértil França gerou.

[41]

PARA OS LEITORES

Poupai, leitores, poupai a esta obra perecível.

Para que pereça, ela não carece do vosso auxílio. 


\section{EPIGRAMAS}

DE

ANTÔNIO DE GOUVEIA

E

QUATRO CARTAS

POÉTICAS

DO MESMO AUTOR

IMPRESSO POR SÉBASTIEN GRYPHE

LYON

1540 


\section{ANTÔNIO DE GOUVEIA A JACQUES DE BEAUNE. SAUDAÇÕES.}

1. Quando por vezes eu me recolhia de estudos mais sérios, Jacques de Beaune, eu me esforçava para concertar num epigrama os assuntos que pareciam dignos de um epigrama. Havia, de fato, para escrever, a disposição, havia essa faculdade, a qual, nascida em meio a quase nenhuma experiência das letras, e perseguida com empenho, algum exercício mal fortalecera, e não faltava o estímulo, teu e de todos os amigos, acompanhado de uma esperança talvez vã, mas ainda assim ardente e inflamado.

2. Mas quando eu dirigia brevemente meu pensamento para os escritores novos e antigos que sobressaíram aclamados e famosos neste gênero, eu fraquejava e desanimava de algum modo: eu via que a popularidade foi concedida à inovação, e a autoridade foi atribuída à tradição.

3. Com efeito, para falar inicialmente de Catulo, ele foi sem dúvida um grande homem, instruído no conhecimento de numerosas e importantes artes, encontrou muitas soluções poéticas com agudeza, escreveu não poucos poemas no estilo romano. No entanto, se quisermos avaliar cuidadosamente a sua obra, pondo de lado toda a reverência escrupulosa com que a Antigüidade nos mantém constrangidos e embaraçados, talvez não sintas saudade de nada que diga respeito à agudeza de espírito ou à pureza da linguagem, e não entendas por que não possam existir novos poemas.

4. Já Marco Valério Marcial, assim como se seguiu a Catulo após um longo intervalo de tempo, na mesma medida o deixou para trás, vencido e superado em todos os aspectos do talento. Embora as magníficas e admiráveis qualidades de Marcial nesse gênero tenham sido evidentes, todavia ele nem esmoreceu o empenho nem desencorajou a tentativa de outros.

5. Claudiano, muito inferior em glória, que, não sendo verdadeiramente popular, ele granjeara a partir dos dois panegíricos, nem um pouco satisfeito, pareceu ter querido aspirar também a esta outra, da qual, na minha inequívoca opinião, parece mal ter alcançado mesmo uma leve sombra.

6. Nossa época forneceu um excessivo número de escritores que foram inflamados, todos ao mesmo tempo, pelo anseio desta glória. Dentre eles, alguns ereceram inteiramente a mais ampla exaltação do talento e da dedicação; outros, satisfeitos com a popularidade advinda da inovação, tendo provocado a aprovação do povo, foram capazes de desprezar o julgamento dos doutos. 
7. Quanto a essa popularidade, embora não possa ou, pelo menos, não deva faltar-me, conviria, no entanto, que fosse desejável sob a condição de que, se não for referendada por nenhum talento ou nenhuma dedicação, eu declare que não venha a ter nenhum valor.

8. De todo modo, vou considerar plenamente satisfatório tudo o que, seja em razão de um pedido meu, seja em razão de nossa amizade, for feito por ti, se vieres a examinar estas sombras de meus epigramas de tal modo que, como amigo, não faças a menor concessão aos erros, nem, por outro lado, admitas que as qualidades, que percebo quanto são limitadas, sejam privadas de seus frutos. Com efeito, quer em respeito ao interesse da nossa comunidade literária, quer em respeito aos mais elevados anseios, tanto meus quanto de todos os literatos, o resultado será que eu - que me deixo influenciar seja pelas vozes dos leigos, seja pelo julgamento tácito dos doutos, seja ainda pelo respeito à posteridade - , ou inteiramente dissuadido, aproveite a tranqüilidade do silêncio, ou ao menos desencorajado desse impulso, seja um pouco mais cauteloso para escrever. Adeus. Lyon, 23 de janeiro.

\section{DO LIVRO AO LEITOR}

Todo aquele que me vir emendado em mil lugares,

Fica sabendo, por favor, qual foi a causa desse mal.

Meu Autor, cruel, me guardava por nove anos,

E a mim, triste, me enfurnara num lugar funesto.

Aqui, entre ratos, traças e baratas eu jazia,

Esquálido, com a cabeleira longa caindo pelo rosto entristecido.

Aqui, abandonado em repouso, se eu parecia ter feito algo errado,

Terríveis chicotadas caíam sobre meu dorso.

Ora um desejo de luz crescia em mim, com a lenta passagem das horas,

Ora uma angústia ansiosa por uma liberdade desconhecida.

Ao acaso ele pegava e relia meus irmãos, guardados em ordem,

Muitos dos quais ele examinara com o mesmo zelo.

Tremendo, escapo e sigo caminho por lugares selvagens:

A sétima lua me vê errante por todo o globo.

Mas, há pouco (ai, aonde meu destino me arrastava, infeliz?),

Eis que meu Autor parou diante dos meus olhos. 
Os seus olhos ardiam com um fogo sangüínário:

Sua voz e a cor do seu rosto emitiam sinais de ameaças devastadoras.

E, quando ele me disse: "Qual é a esperança, fugitivo, de uma salvação,

[agora que ela está perdida?",

Meu rosto empalideceu: meus cabelos dourados se enregelaram. 20

Três vezes tentei eu confiar em meus pés, três vezes

Os pés, lentos, falharam o apoio à minha tentativa.

Logo a seguir, ele, feroz, pisa em mim, caído no chão, e dilacera minha face,

Com o pé duro, três e quatro vezes.

Com chicotadas, enquanto derramo lágrimas, ele me castiga e me

[fustiga, pondo-me à beira da morte,

E nem a piedade paterna, nem minhas preces súplices valeram de algo.

Enquanto ele tenta arrancar os galhos de uma árvore imponente,

Para dar minhas entranhas ao fogo de uma pira,

Eis que o temor, nada preguiçoso, concedeu asas rápidas a meus pés.

E eu tomei a decisão de fugir a tempo de continuar vivo.

Se o destino me mantiver mais uma vez sob tais provações,

Ó leitor, meu amigo por todo o tempo, adeus. 


\section{EPIGRAMAS DE ANTÔNIO DE GOUVEIA}

[1]

A D. FRANCISCO I DE VALOIS, SEMPRE AUGUSTO REI DA FRANÇA, DO

LIVRINHO

Muitas vezes pedi ao meu Autor para que eu me tornasse teu, Francisco:

Oh, quantas vezes ele rejeitou minhas justas súplicas!

Eu juntava lágrimas às súplicas. Então ele me disse: "O quê,

Péssimo?! O quê?! Então pensas que mereces viver?!"

[2]

\section{A CATHERINE}

Assume, Catherine, o patrocínio de meu livrinho,

Que, juntamente com o seu senhor, deseja ardentemente ser teu.

O que antes não dei, Catherine, agora será possível dar.

Bem sabes que não tenho nenhum direito sobre este senhor.

[3]

\section{AO LIVRINHO}

És novo, perecível Livrinho; mas se alguém ficar

Proclamando isso, e desprezar a tua idade,

Se for lícito e conveniente, diz-lhe tu: “Ora, ora, Bom Leitor,

Qual é o problema? Acaso os antigos não foram novos? 
Ó beleza, ó nova glória da nossa pátria e do nosso povo,

Tema gigantesco e múltiplo para os futuros poetas,

Eu tentaria, Fernandes, de muito bom grado te colocar sobre o Olimpo

E, declamando versos, pôr-me à altura dos píncaros de teus méritos,

Se tua reconhecida virtude não se erguesse mais elevada do que todo

[mérito humano,

E tua fronte já não estivesse colocada entre os astros.

[5]

\section{AO MEU IRMÃO ANDRÉ DE GOUVEIA}

Observas com admiração o que escrevo sem talento,

Nem um pouco perturbado pela inveja.

Meu irmão, embora sem talento,

Este não é um livro perturbado pela inveja.

[6]

\section{A AUSÔNIO, POETA DE BORDEAUX}

Desde que a norma dos antigos costumes seja respeitada por ti,

Dizes, que a Musa sóbria brinque com gracejos mistos.

Mas, embora a norma dos antigos costumes não tenha, para mim, nenhum valor,

Minha obra evitará os gracejos indecentes.

Pois terá sido suficiente, a quem se cala, ter vivido honestamente.

A quem escreve não basta que a vida seja casta. 
EM MEMÓRIA DE GUIDO RANGONE

APROXIMA-TE, SEJA QUEM FORES, SE ADMIRAS

O POVO FRANCÊS. GUIDO RANGONE, QUE VIVEU

O SUFICIENTE PARA A NATUREZA, PARA A VIRTUDE,

PARA A GLÓRIA E PARA A PROSPERIDADE,

JULGA QUE VIVEU POUCO PARA SI MESMO.

SE PERGUNTAS POR QUÊ, ELE DIZ QUE

NÃO VIVEU O SUFICIENTE PARA A FRANÇA.

[8]

AOS AMIGOS

Embora eu tenha colocado vossos nomes nestas folhas perecíveis,

Ó corações muito mais queridos por mim do que eu mesmo,

Creio que nem eu nem meu pobre livrinho fizemos nada de errado:

Minha Talia apenas cumpre com seu dever.

Que ela pereça junto com o Poeta, pois mereceu:

Vossos nomes é que não mereceram perecer com o tempo voraz.

[9]

\section{DO LIVRO A SÉBASTIEN GRYPHE}

Pelo fato de que sou lido e estou vivo, devo, certamente, agradecer muito

A ti, Gryphe, dedicada lima dos bons estudos.

Pois se por acaso não tivesses estado ao meu lado, quando eu estava semimorto,

Crê em mim, eu podia ter morrido bem mais de uma vez. 
Ó tu, afortunada irmã, com um irmão tão poderoso,

Cujas ameaças são temidas por toda a terra e todo o mar.

Ó tu, afortunada, com um marido tão justo e tão poderoso,

A quem tu vês que o próprio Marte não é capaz de dar nenhuma ajuda

[nos combates.

Qual dos dois, no entanto, é teu maior mérito? Sendo eu juiz, decerto

Um é prêmio da Virtude, o outro, do Destino.

[11]

EM MEMÓRIA DE JEAN D'YBERROLA, SENADOR DE BORDEAUX

Uma lápide exígua cobre os ossos de Yberrola,

Em quem a Fortuna, a Ciência e a Virtude rivalizaram.

Elas, porém, se depositamos ao menos alguma confiança na memória dos

[tempos,

Mantêm um nome que em tempo nenhum vai perecer.

Se perguntas por que não estão sepultadas no mesmo túmulo,

É que, num túmulo tão exíguo, não puderam ser contidas.

[12]

CHARLES CANDELLE

Diz Lacroix que "Picardia" vem de pega: mas,

Na minha opinião, a região não deriva o nome disso.

Eu tendo a acreditar que esse nome vem do nome do picanço:

De fato, é um povo marcial: e o picanço é a ave de Marte. 


\section{EM MEMÓRIA DE LUCILA}

Lucila pariu gêmeos, os quais,

Cumprindo, um e outro, com seu dever, separam-se.

Um consola as lágrimas do pai infeliz, e o outro

Preferiu ficar contigo, e foi ao encontro da morte.

\section{A PINASSE}

Esse teu burro mal conhece capim, mal conhece a gorda aveia,

Mas, apesar disso, ele continua gordo.

Tendo a ti como professor, Pinasse, não era possível que o teu burro

Não aprendesse a viver até mesmo com nada.

\section{A CATHERINE}

Versão de um poema em francês de Clément Marot

Até o momento em que me atinges, Catherine, com uma neve candente,

[eu pensava

Que a neve não tinha fogo; a neve, no entanto, era fogo.

Ora, o que posso fazer, se o ardor, falaz, se esconde na neve,

Se o frio e o fogo se ocultam na água congelada?

Acaso, Catherine, a chama que vive em meu coração

Não cresce com o frio? E não é ela vencida por um fogo igual? 


\section{A ARNAUD LOUIS}

Se não me deves nada, Louis, por que pagas o não-devido,

Fazendo-te, por tua própria vontade, meu devedor?

O que posso dizer que é isso, senão que queres ser devedor,

Para que possas deste modo ser credor?

Se não sabes por que esta urna que cobre as cinzas de Manuzio

Não cobre, esta mesma urna, as nove Musas,

É porque tu ignoras quanto ele se dedicou, à perfeição,

Para que elas pudessem sobreviver incólumes a cada autor.

[18]

\section{A MARCIS}

Invocas Maria com um sussurro rouco e incessante,

E num segundo ruminas, velho senhor, mil ave-marias.

Em seguida, prometes a ti mesmo as recompensas de uma vida feliz

E, livre de preocupações, aguardas o dia da tua morte.

Oh, como te ilude uma falsa imagem de devoção!

Deus não julga que rezar seja mexer os lábios. 
[19]

\section{A HUBERT SUSSANNÉE}

Então concordas que existam quatro "Virgílios" franceses,

E queres ter um lugar entre esses quatro.

Por esse raciocínio podes me declarar o quinto; ou o sexto,

Caso possa existir algum poeta pior do que eu.

[20]

EM MEMÓRIA DE CIRET, SENADOR DE BORDEAUX

Ciret, pai da pátria e farol do Senado,

É quem vês sob um túmulo exíguo.

Se a Morte tivesse visto, em toda a vastidão do mundo,

Um inimigo das injustiças semelhante a ele,

Nem à pátria, à esposa, aos filhos, nem às próprias leis

Teria feito esta injustiça.

[21]

A JEAN LACROIX

Quando troveja, Vallée foge com pés assustados para o fundo da adega.

Será que ele pensa que deus está na adega? 
Ó irmã e esposa de reis, ó outro rebento de uma progênie

Grandiosa, ó imagem imensa de um imenso irmão,

Eu cantaria a ti, e ao teu nome, e ao nome dos teus,

E à tua virtude, que repousa na altura dos astros, se estas folhas exíguas

Pudessem sustentar o peso de méritos tão grandiosos.

\section{A DIOGO DE TEIVE}

Farejar uma refeição escondida na cozinha:

Tu dizes que isso não é próprio de um sujeito sem inteligência, Teive.

Farejar uma refeição escondida na cozinha,

É mérito, afirmo eu, do nariz, Teive.

\section{A UM CACHORRINHO CUJO NOME É PARIS}

Quem quis que tu tivesses o nome de uma cidade tão importante,

Cachorrinho, minha alegria,

Achou por bem indicar teu valor e tua esperteza

Com um nome tão importante.

A FILENO

De onde tiras um amor tão grande por ti mesmo? Controla essa tua loucura!

Afinal, Fileno, não tens nenhuma disputa, nenhum rival. 


\section{A ZOILO}

Zoilo, vive bem e com saúde, e perdoa ao meu livrinho:

Pois, assim que ele sofrer teus ataques,

A que ponto ele se exaltará, com raiva!? Que exageros ele, insolente,

Despejará da boca!? Então ele terá dito que seu autor não tem

[sensibilidade,

E que ele, inocente, sofreu por longo tempo horríveis rasuras.

Ah, não sabes o que é, Zoilo, a preocupação de um autor!

[27]

A MARCIAL DE GOUVEIA, MEU IRMÃO

Irmão amigo, dar-te poemas, com meu livro,

Seria como plantar árvores num bosque já denso.

[28]

A BACO

Por que, em louvor a ti, deus Baco, Zébédée não permanece atado ao teu altar,

Se o bode é uma oferenda sacrificada com gratidão em teu rito?

É igual o sacrilégio de um e outro, é igual o crime, Baco:

Este é a destruição da vinha, e aquele, do vinho. 
EM MEMÓRIA DE ANTÃO DE GOUVEIA, MEU ÓTIMO E MERITÍSSIMO AVÔ

Da tua espada, da tua mão direita a Morte teve medo;

Dessa tua mão, ilustre nas guerras, ó meu Avô, a Morte teve medo.

Ela não ousou, enquanto tua juventude esteve intacta, combater contigo:

Com uma velhice pesada, ela trata de primeiro esmorecer as tuas forças.

Que mérito pode haver nessa vitória?

[30]

\section{AO MEU LIVRINHO}

Pequeno livro, se alguém te desprezar,

Diz-lhe tu: Meu Autor

Escreveu bons epigramas para os doutos, escreveu maus para os amigos.

Qual deles, ó cidadão, aqui reconheces ser o teu?

\section{VÊNUS}

Versão de um poema em francês de Antoine Alaigre

Viu-me nua Páris, e nua me viu Adônis,

Um, meu juiz, o outro, meu amor.

Mas, Apeles? Quando me teria visto nua Apeles de Rodes?

Mentira! Ele teria visto, por certo, uma Deusa!

Contudo, quem me pintou assim à perfeição, é preciso

Que tenha visto Vênus nua também ele! 
[32]

A CLAUDE DE BEAUNE

VÊNUS

Imitação

Viu-me nua Páris, e nua me viu Adônis,

Um, meu juiz, o outro, meu amor.

Mas quando, Beaune, eu fui vista por teu pai?

Mentira! Ele teria visto, por certo, uma Deusa!

Porém, quem gerou uma tal mulher, é necessário

Que tenha visto Vênus nua também ele!

[33]

A JEAN MICHEL

Escapaste, Michel, da espada, do fogo e da cruz.

Então teu pé não vale mais, para ti, que tua própria vida?

[34]

A JEAN DE LACROIX

Marcial, por seus argutos livros de epigramas

Conhecido em todo o mundo,

Tu perguntas quem foi, e negas que tenha sido,

Apesar dos poemas argutos por todas e todas as páginas,

Um homem conhecido em terras desconhecidas.

Tu o acusas de mentiroso, e sustentas isso abertamente:

Só não sabes que esse recurso é hispânico. 


\section{A JEAN ALBENAS}

Se os latinos podiam dizer "luitura",

Por que os espanhóis não podem dizer "eluitura"?

Ou será que podem, e sempre puderam, e sempre poderão,

E quem diz que não pode não sabe o que é "luo"?

DO LIVRINHO

A ÉMILE FERRET

Meu autor, insensível e intratável, jurou me lançar três e quatro vezes

Ao fogo corretor.

Mas eu, na verdade, mantenho a esperança, e não é uma esperança vã que

[iludirá minha alma:

É que ele me perdoou pelo fato de tu dizeres que gostaste de mim.

[37]

A CATHERINE

DEVO ESPERAR RECOMPENSA DO AMOR, QUE NÃO ENXERGA QUANTO FAÇO POR MERECER

NEM PODE AVALIAR ISSO PELA EXPERIÊNCIA DE VIDA?

ORA, DE QUE ADIANTA SERVIR A UM MENINO, E CEGO? 
Agora já podes ficar contente com a tua sorte, Póstumo,

Depois de teres sido agraciado com duas filhas.

Recebeste mais do que desejavas, Póstumo.

[39]

\section{A GIOVANNI ROMANO, CREMONENSE DE CASALMAGGIORE}

O deus que te brindou com as artes da Medicina, Romano,

Teve inveja de Esculápio.

[40]

\section{A ÉTIENNE DOLET}

Por que não te elogio, talvez, Dolet, perguntes.

Isso tu fazes melhor do que eu.

A BLANCHE DURER, ESPOSA INTEGÉRRIMA DE JACQUES REYNAUD D'ALEIN

Qual nobreza é a tua, qual a virtude, a inteligência, a elegância

Dos teus modos, qual a graça,

Qual, enfim, é a eloqüência de tua língua melíflua,

Tu és capaz de descrever muito melhor do que qualquer um. 
Se um livro esquálido, desgrenhado, acanhado Alcançar as cidades lusitanas, Osório, É meu; toma-o, e devolve-o ao autor corrigido.

O castigo merecido não o soube dar eu.

Um marinheiro transportava o rei por mares adversos, E, ao mesmo tempo, chorava o pai, afogado em águas revoltas.

Diante disso, o rei the disse: "Que tamanha loucura te moveu, tolo, Para que ousasses dar velas ao mar infiel?" O piloto lhe respondeu: "Por que te entregas, ótimo rei, Ao leito macio onde sabes que teu pai morreu?" 
A lebre que ganhei, meu irmão, é servida a ti: acaso

Não é isso, realmente, ganhar e perder uma lebre?

[46]

\section{DO LIVRINHO AO LEITOR}

Sou breve: com esta única virtude espero agradar.

Com a brevidade, leitor, há menos defeitos.

AO LIVRINHO

Meu pequenino livro, que detesta as mãos e a figura do teu autor,

Se a ti te domina o desejo por uma luz mais ampla,

Anda, vai atrás de mãos desconhecidas e tetos inóspitos,

$\mathrm{Tu}$, que podias estar muito mais seguro em casa.

Porém, para que escapes dos açoites das destras estranhas,

Dirás: “Os erros, leitor amigo, são do meu autor".

\section{A FEDRO}

Não sabes por que não és capaz de superar os antigos na poesia?

É porque combates com fantasmas, meu caro! 
Ó Saint, ó homem que sobrepujaste os perigos da terra e do mar, Ó espírito invencível, ó ornamento magnífico da pátria, A ti sou eu capaz de exaltar? Ó Musas, áurea prole de Júpiter, Gerai outro Homero, eis um novo Ulisses.

\section{A MÁXIMO}

Sou chamado por ti, Máximo, sempre, de importuno,

Quando peço esse teu queijinho.

Por que não me envias o queijinho, Máximo, todo?

Ou por que me culpas pelo que tu fazes?

\section{A CATHERINE}

Só me darei, como um presente, a ti, Catherine, de bom grado,

Depois que me tiveres devolvido a mim.

\section{A MARTINHO FERREIRA}

Se alguns poemas em meu livrinho parecerem defeituosos,

Se alguns menos latinos, alguns pouco faceiros,

Deveriam ser desculpados por ti em função do momento pelo qual

[passava seu autor.

Não é possível ao mesmo tempo escrever corretamente, e amar. 
Lendo os divinos poemas de Petrarca, Febo diz:

"Este é um loureiro; que seja apenas Laura, é o que se permite!"

Disse; e a ela, que jazia derrubada por uma flecha, ele grita: "Vai agora,

Vai agora, e despreza, ímpia, os grandes deuses!"

Laura, morrendo, diz: "Eu amo Febo:

Meu erro foi ter agradado a um Deus."

\section{A ÉMILE FERRET}

Como nada me resta, Ferret, senão poemas,

Nada recebes de um português, senão um poema.

Tudo o mais o destino me tirou, deixando

Apenas aquilo que eu podia chamar, de modo legítimo, meu.

\section{A CATHERINE}

Se perguntas o que faço na cidade de Lyon,

E se a ti ainda pode tocar alguma preocupação a meu respeito,

Vivo a lamentar que a noite demore a suceder à luz,

E é com lágrimas que umedeço e passo o tempo.

Mas o Amor, cruel, não é vencido por lágrimas nenhumas:

Sua Mãe surgiu do meio da água. 
Vira, e podia ter evitado a morte iminente

Tarrega: mas por sua própria vontade ele se coloca no caminho dela.

A ele os Filhos e a Esposa compelem, derramando lágrimas:

"Aonde vais com tanta pressa? Por que não te escudas com as artes médicas?

Aonde vais com tanta pressa?" Ele diz: "Vou trocar a vida pela morte".

\section{A JACQUES DE BEAUNE}

No momento em que eu pegava uma lebre, meus encantos sedutores fugiram. Uma só mão não pega duas coisas, Beaune.

\section{A D. JOÃO III, REI MÁXIMO DE PORTUGAL}

Uma vez que a ti não faltam nem forças, nem recursos para as batalhas,

E a sorte da guerra se dá e está ao teu arbítrio,

Por que não atacas os povos vizinhos a ferro e fogo?

Por que não praticas uma justiça injusta, a teu favor, por toda parte?

Esta é a tua divina e inteiramente régia virtude:

Poder destruir, certamente; não querer destruir, porém.

[59]

À MEMÓRIA ETERNA

PARA CATHERINE, AINDA VIVA, GOUVEIA

JUROU QUE, MORTA ELA, NÃO PODIA

NEM LHE FALTAR, NEM LHE SOBREVIVER. 


\section{AO ARQUIPOETA}

Do conjunto dos poetas subtrairás todos os poetas:

Desse modo, com certeza, te tornarás o Arquipoeta.

[61]

A RESPOSTA DO AMOR

Versão de um poema em francês de Jean Albenas

O Amor, ostentando fisionomia e toga de sábio,

Tratava, em lugar público, de assuntos dignos até mesmo de Júpiter.

A ele eu perguntei: "Por Vênus, por que o amargor segue o amor?"

Ele me respondeu: "Para que, sozinho, o amor não seja amargor."

[62]

\section{A SÉBASTIEN GRYPHE}

Há uns maus, há os piores, Gryphe, e há os péssimos, a maioria.

Poucos, porém, seriam, por este raciocínio, maus. 


\section{A JACQUES DE BEAUNE}

Quando enumeras os poetas que o nosso tempo produziu,

$\mathrm{Na}$ lista dos poetas acertadamente me incluis, Jacques.

No entanto, se alguém pesar os poetas com uma balança justa,

Não serei eu, crê em mim, digno deste peso.

[64]

\section{O ENGANO DO CUPIDO}

A estrangeira Gelasina foi ao encontro do Amor vendado,

E o Menino se pôs a dizer: "Olá, Mãe!”

Ela nada respondeu; e, tendo tirado subitamente a venda

Dos olhos, o Menino se constrangeu e enrubesceu.

"Menino Cego, de onde vêm teu pudor e tuas lágrimas?

Vês que olhos descobertos podem se enganar do mesmo modo."

[65]

\section{A JACQUES REYNAUD, MONSIER D'ALEIN}

Que agradecimento eu posso te prestar, ó D'Alein, o mais perfeito descendente

De heróis, magnífica progênie de uma magnífica família,

Que agradecimento posso te prestar? Tu me recebes, de boa vontade,

Em tua casa e mesa, a mim, um desconhecido, obrigado a diversos desvios

[de rota.

Que piedade, que gratidão da tua parte faltou aos meus problemas?

Que leis da hospitalidade não foram cumpridas por ti?

Oh, que os deuses me dêem o tempo de uma vida tão longa

Quanto venha a ser suficiente para disputar contigo em número de favores.

Ainda que seja inútil disputar sem esperança de vencer. 


\section{A PALIDEZ DA DONZELA}

Versão de um poema em francês de Antoine Alaigre

O Amor instalara sua praça-de-guerra em pleno coração da jovem:

E era duro demais num peito delicado.

E, dado o fato de sofreres mais, o Menino, férreo - ah! - em demasia, e [sangüinário,

Absorve toda a vida do seu corpo.

Então o coração, quando sentiu as forças abatidas, convocou,

Como tropa auxiliar, a retaguarda de sangue da sua face vermelha.

[67]

\section{EM MEMÓRIA DO ADVOGADO JEAN MONTAGNE}

Montagne resgatava, das garras da morte, os réus temerosos,

Graças ao poder de sua eloqüência e discernimento.

As Parcas lamentavam que seus poderes divinos lhes tivessem sido retirados,

E que não mais fiassem os férreos destinos com seus fusos.

Sem demora, arrebatam Montagne, sem direito algum.

$\mathrm{Ah}$, não foi assim que ele livrou os réus da morte!

[68]

A PEDRO ÁLVARO

Os epigramas que ofereço são poucos, admito, mas são mal feitos, Pedro:

Acaso não podes dizer, com toda a razão, que são muitos, em excesso?

\section{A CUPIDO}

Contra ti eu me cingiria com as armas de meu pai e avô,

Menino Cego: mas que glória seria produzida por uma tal vitória? 


\section{A DISCUSSÃO DO CORPO E DA ALMA NA DOENÇA}

Versão de um poema em francês de Clément Marot

O Corpo exige ajuda médica; a Mente arde por abandonar a terra

E rejeita continuamente as mãos dos médicos.

O Corpo admira a terra, a Mente, etérea, os astros, dos quais é afim.

Ó Deuses, com que brados violentos e assustadores eles discutem!?

“Eu?" - diz o Corpo - "Sucumbir assim a uma doença grave?"

A Mente, por seu lado: "Deter-me sempre com delongas

[detestáveis?"

“És cega!" - diz o Corpo. A Mente, ao contrário, retruca: "Erramos

[um e outro:

Fiquemos um e outro ao arbítrio de Deus Todo-Poderoso.”

[71]

\section{A CLÉMENT MAROT}

Marot, magnífica voz da França,

Se, a partir de teus bons poemas em francês,

Faço maus poemas em latim,

Perdoa a este estrangeiro, teu hóspede.

\section{DE CLITEMNESTRA A ORESTES}

Versão de um epigrama grego

Acaso é no meu ventre, ou acaso é no meu seio que pretendes enterrar

[essa tua espada desembainhada?

Meu seio te alimentou, meu ventre te carregou, assassino. 


\section{DO LIVRINHO AO BISPO PIERRE CHATELAIN}

Enquanto fujo, por terra e mar, de meu terrível pai,

A sétima lua me vê, um errante pelo território francês.

Eu, exilado, sem pai, somente estou a salvo graças à tua vontade.

Embora em território desconhecido, irei sobreviver.

\section{A CATHERINE}

Confesso, lutei longamente contra o brutal amor,

Não queria submeter meu pescoço ao jugo do Menino.

Eu implorava, enlouquecido, às doutas Irmãs, acompanhadas de seu irmão,

E ao casto poder da deusa caçadora.

A mim, infeliz, nem Febo, nem a Musa me trazia socorro,

Nem foi Diana vista muitas vezes por meus cães.

Venceste: ter vencido, porém, não te trouxe nenhuma glória.

Um homem terno sucumbiu ao teu ferimento, deusa.

\section{A HUGUES SALEL}

Se por acaso eu digo ao meu livrinho: "Eia, vai, cresce!",

Ele me responde: "Por Hércules, pai, tu não estás sendo sensato."

Quando pergunto o motivo, ele diz o seguinte, rindo:

"Só porque eu, sendo um livrinho, agrado, tu esperas que eu possa

[agradar, como livro?" 
Se a minha fala fosse tão eloqüente quanto é estúpida, Eu teria dito quanto tua fala é eloqüente.

[77]

\section{EM MEMÓRIA DE POMPONE TRIVULCE}

Tu que vês este túmulo,

Vês o túmulo de Pompone,

Vês o túmulo de Trivulce.

[78]

\section{EM MEMÓRIA DE SIBYLLE BARCY}

Enquanto o próprio Pai dos homens se prepara para levar aos céus

Tanto o espírito de Sibila, quanto a prisão terrena do seu espírito,

Eis que a Terra, lançando os braços ao colo da filha, rodeando-a

Diz: "Entrega a alma ao pai, o corpo à mãe!"

A filha, com pena das justas lágrimas da piedosa mãe,

Deixou no seio materno um corpo sem vida. 


\section{A ANTOINE ARLIER}

A respeito dos primeiros delírios da minha juventude imatura,

Acaso não dizes e pensas, erroneamente, que tem algum valor?

Ou na verdade (e, de fato, que tamanha blasfêmia não saia da minha boca!)

O teu julgamento é correto, e a tua língua sensata?

[80]

\section{A JAN HABERT}

Os epigramas que tu julgas poucos, Jan, eu julgaria,

Se bons, muitos, na medida; se maus, muitos, em excesso.

[81]

\section{A JEAN ALBENAS}

Querer que eu coloque teu nome em meus papéis

É, penso eu, querer perecer junto com meus escritos.

[82]

EM MEMÓRIA DE JEAN ALBERT DE LA RÉOLE

Não te espantes, viajante, com o pequenino túmulo de Albert:

Pois seja qual for o túmulo com que

Albert pôde ser abrigado, também puderam ser abrigadas as sábias Irmãs,

As Graças e a Piedade. 


\section{AO FUNDANO}

Se, ó cidadão de Fundos, perguntas quão bom é aquele poeta

Públio, aquele teu querido, aquele teu querido Célio, Aquele teu querido Célio, autor da divina "A Persa",

É um ótimo médico aquele teu querido Célio.

Rufino pensava que caiu do céu,

Pois Rufino desconhecia seus pais.

[85]

\section{A JACQUES DE BEAUNE}

Por juramento Lorenzo haveria de corrigir

Todos os antigos, se tivesse podido.

Se não sabes por que ele teve esse atrevimento além da realidade e da arte,

A causa está à mão: ele era escrupuloso.

BASSA

O fantasma do marido de Bassa, homem horroroso de ver,

Ao qual o mal-gálico consumira lentamente,

Apareceu a Bassa e disse: "Ó tu, outrora metade da minha vida,

Se tens alguma piedade, se tens alguma fidelidade,

Por favor, liberta este pobre infeliz, finalmente, destas chamas". Mas ela

[respondeu:

"Marido, tu precisas suar". 
EM MEMÓRIA DE FRANCESCA PERUSIA

A Vênus

Diante do fato de que Francesca Perusia foi arrebatada na flor da idade, Por que tu e teu filho chorastes?

Por que chorastes, se o tempo nada podia acrescentar

À jovem em termos de beleza, virtude ou talento?

[88]

\section{A CHARLES DE SAINTE-MARTHE}

Dizem os pastores, dizem, Charles, que sou poeta.

Dizem os pastores: mas não sou eu que vou acreditar piamente neles.

[89]

\section{A JACQUES DE BEAUNE}

Eis que de repente a fértil França produz, numa única geração,

Dolet, ferino no iambo,

Macrin, que sabe aplacar, com a curva lira,

As ameaças ardentes dos Deuses,

Bourbon, fluente nos chistes e gracejos latinos,

Famoso por seus versinhos sérios,

E a vós, ó Visagier, Brice, Sainte-Marthe, Ducher,

Esplendores da sagrada poesia.

Se não sabes o que faço, enumero, Beaune, os poetas

Que a fértil França gerou. 


\section{A FRANCISCO DE MELO}

Se minha obra surgir diante dos teus olhos

E alcançar tuas mãos divinas, Melo,

Perdoa, por favor, as minhas folhas, e perdoa também ao seu desgraçado Autor:

Nem eu, nem minhas folhas temos culpa de nada:

Três vezes elas desejaram morrer, três vezes quiseram perecer na chama voraz:

Três vezes as mãos paternas tombaram ao tentar.

\section{ENFANS}

Vagabundo, falastrão, fútil, mentiroso, descarado, insistente, Ingrato, incapaz, fingido, inábil.

Se perguntas, Enfans, por que Jean Michel é tudo isso,

Fica sabendo que o velho foi monge.

\section{A SAINT-AMANT, MERITÍSSIMO CAVALEIRO TEMPLÁRIO}

Ó Saint, vou valorizar menos tuas desventuras, teus sacrifícios em terra e mar,

As tuas longas e numerosas rotas,

Do que os diversos desvios de percurso do ítaco Ulisses? Ele

Agiu impelido pelo desejo de vingança.

Ó Saint, tu, é por tua própria vontade que vês o oceano e as terras,

O sol cadente e o nascente.

A ele, Ulisses, grandes punições é que o levam em torno de todos os oceanos, A ti é a gloriosa virtude de tua alma. 
[93]

\section{A JULES CÉSAR SCALIGER}

A ti não é o nome do troiano Iulo que te faz um herói,

Nem a antiga glória da casa della Scala.

Por que tu precisas recorrer aos antepassados? É a tua ínclita virtude que te faz

Um deus semi-homem e um homem semideus.

[94]

À MEMÓRIA ETERNA

O MACAQUINHO DE CATHERINE, QUE

AQUI JAZ, VIAJANTE, COMO NÃO PÔDE

SUPORTAR A AUSÊNCIA DE TRÊS DIAS DA DONA,

DEIXOU ESTA VIDA. EU, COMO HOMEM,

NÃO DEVO INVEJAR A MORTE DESSE ANIMAL?

[95]

HÉCUBA

Versão de um epigrama grego

Quando a descendente de Cisseu viu a espada cravada no pescoço

Da filha, com os cabelos brancos desgrenhados

Acusa o céu, as terras, acusa Aquiles,

Ai!, mãe pia, mas que não teria forças para salvar a filha.

Vivo, ele capturou Heitor: morto, levará consigo para o Orco

O que resta da minha progênie?

Que crime, meus filhos, praticastes contra o Eácida? Que ao menos,

Que ao menos o fantasma cruel poupasse meu ventre! 


\section{A CATHERINE}

Disse eu: “Ó graciosa Deusa, mãe dos dois amores, sê propícia!

A casta Diana ajudou seu poeta."

Parei, tomado pela emoção, e, para acompanhar a prece, estendi

[as mãos à divindade.

"Eu sou, Deusa, eu sou um soldado do amor casto".

Ela nada disse, e, de repente, desviando o olhar, fugiu.

Ai! Nem mesmo assim tens piedade de mim, Catherine?

Devo arder, logo eu? Devo morrer, por ter conhecido, provado e visto?

É um pecado, para mim, pensar em viver?

A BAVIO

Tu me dizes cada vez mais que estou começando a ser poeta.

Se falas a verdade, estás começando a ser infeliz.

[98]

\section{BENOÎT CRASSE}

Se alguns poemas forem, como decerto serão, indignos do seu autor,

Fica sabendo que eles foram o resultado do momento pelo qual

[eu passava.

De um lado me torturava o amor cruel, de outro a pobreza,

Esta mais humilhante, aquele, porém, muito mais implacável.

Somente repouso para mim, e o proveito de um tempo que tarda a passar,

É que meu talento perseguiu: ele não perseguiu a fama. 


\section{AO MEU LIVRINHO}

Enquanto eu trabalhava em ti, pequenino Livro, noite e dia,

Apareceu diante dos meus olhos a casta Diana.

E ela disse: "Ó poeta esquecido das lebres e dos cães,

Por que, preguiçoso, começas uma nova obra?

Era esta aquela antiga fidelidade, que outrora, traidor,

Me davas com freqüência nos campos férteis da Gasconha?

Por que te desvendei os bosques? Por que as tocas das feras?

Por que incitei os cães velozes pelas altas montanhas?

Por que, enquanto estávamos os dois deitados, sob o sol ardente,

Cansados em nosso leito de relva,

Eu te ensinei qual a natureza dos cães, qual a da lebre arisca,

Que tratamento pode afetar o caçador,

Que remédio Quíron deu aos cães domesticados?

Certamente para que o vento levasse promessas vãs.

Deixe de lado os gracejos latinos, termina o trabalho interrompido:

Em nugas qualquer poeta é bom.

Ela diz isso, e desaparece dos olhos dos mortais;

E assim deixou o poeta atônito.

Pequenino livro, é preciso obedecer às advertências da Deusa:

Ela está preocupada contigo, ela está preocupada consigo.

Os Virgílios provavelmente perdoarão a ti, por seres livrinho:

Que tu nunca recebas esse perdão como Livro. 
[100]

DO LIVRINHO AOS LEITORES

Poupai, leitores, poupai a esta obra perecível.

Para que eu pereça, o autor não carece da vossa ajuda.

FIM DOS EPIGRAMAS 


\section{DE ANTÔNIO DE GOUVEIA A JACQUES REYNAUD D’ALEIN. SAUDAÇÕES.}

1. Se tu, tua esposa e teus filhos passam bem, que ótima notícia, eu também passo bem.

2. A edição anterior, Jacques Reinaud, conteve poemas que, para usar de maior franqueza, começo a achar frios, tolos, indignos de mim. Passado pouco tempo, chegaram às mãos das pessoas muitos epigramas desse tipo, aos quais meu caro amigo Beaune - que apressou, contra minha vontade, a edição dos poemas, e, na mesma medida, sustentou o seu patrocínio - defenderá, se assim desejar.

3. Se me queres bem, tudo que houver na edição anterior em que, na tua opinião, eu me afasto grandemente de todos os literatos, receberá a punição por essa temeridade do autor. Eu garanto com a maior seriedade e convição que tremo muito e me atormento em minha alma por qual seja o julgamento futuro de meus escritos: pois aprendi e experimentei que os tempos costumam ser injustos com seus próprios talentos, e isso faz com que eu me esforce pouco em relação à minha própria época.

4. Se acaso parecer a alguém que eu sou um crítico que se projetou contra os poetas de meu próprio tempo, que ele entenda que alguns são elogiados por mim, e outros são convidados a escrever e soltar mais livremente o riso, com essa mesma liberdade, afinal, que costuma haver em alto grau neste gênero poético, mas que costuma ser moderada e comedida nos meus hábitos morais.

5. Que eu exponha livremente para ti, como se fosse para mim mesmo, o pensamento que carrego em minha alma. Surgiu de repente um tal de Gouveia, um desconhecido, que, na minha opinião, é um gênero inteiramente novo e inédito de tolice; que eu, embora querendo ser chamado e considerado poeta, só escrevo uma obra digna de chicotadas (pois é muito apropriado e decerto é necessário usar dessa liberdade ao falar contra os ignorantes). O que eu não prometo a meu respeito? Nada que envergonhe a mim, aos pósteros, aos contemporâneos, aos antepassados. De fato, eu admito com tranqüilidade que falo bobagens, e, na verdade, não sou capaz de nada melhor; por outro lado, é motivo de orgulho que os que seguem os melhores fiquem bem para trás; nem pude nem tive que proclamar disfarçadamente que eles são vazios e insatisfatórios. 
6. Estão enganados os que pensam que eu invejei a fama ou o talento deles, estão enganado, crê em mim, Jacques Reynaud: não há nada neles de tão importante, a tal ponto que, para mim, é mais fácil criticá-los do que imitá-los: mas quis testemunhar, perante ti e todos os literatos, que eu percebi de um modo inteiramente judicioso como eu deveria pensar e me pronunciar a meu próprio respeito, por compreender do que todos nós somos capazes (pois, de fato, pertenço à mesma lista ou de incompetentes ou de loucos).

7. Que os deuses me façam mal, se alguém me respeita menos do que eu próprio, se me castiga menos, se me despreza menos: muitos dos meus poemas que são aprovados pelo público em geral, muitos dos que são aprovados pelos medianamente eruditos, muitos dos que são aprovados pelos próprios poetas, são epigramas que sou capaz de julgar indignos até mesmo de serem dados à luz. Mas se fôssemos feitos poetas como os artífices das demais especialidades, os quais prestam um juramento, nem haveria tamanha quantidade de poetas, nem este modo de escrever seria desprezado e mal visto pelos doutos, e relegado a espíritos rústicos. Mas ó tu, adeus: a fera fugirá, se não ataco: a caçada

Não aprendeu a tolerar longas demoras. -
conforme já escrevi.
Mais uma vez, adeus. 


\title{
de \\ ANTÔNIO DE GOUVEIA
}

\section{Quatro Cartas}

\author{
ANTÔNIO DE GOUVEIA A GIOVANNI ROMANO, CREMONENSE DE \\ CASALMAGGIORE. SAUDAÇÕES.
}

Quanto mais me esforço, tanto menos consigo retribuir a teus favores para comigo, Giovanni Romano - a menos que julgues plenamente satisfatória esta minha obra, dedicada a ti -, uma vez que conservo na memória o que não posso esquecer. Como eu sentia que tu tinhas esse desejo, devotei-me a que o meu testemunho da tua bondade e da minha lembrança alcançasse a posteridade, fosse qual fosse o valor dele: ele será, provavelmente, por tua recomendação, eterno. ADEUS.

ANTÔNIO DE GOUVEIA A CATHERINE. SAUDAÇÕES.

Tal é a força do amor, Catherine, que, para mim, embora ficar calado não seja nada sensato, falar tolices também é inevitável. O que fazer? Eu, por Hércules, nasci para ter a glória do amor mais agradável que a glória do talento. Adeus. 


\section{DE ANTÔNIO DE GOUVEIA QUATRO CARTAS}

\section{Primeira Carta}

\section{DE GOUVEIA A CATHERINE}

Eis, Catherine, uma carta que talvez não desejes,

Enviada a ti por um homem de Portugal.

O que não consegui te falar, na tua presença,

De algum modo minha mão direita conseguiu escrever.

Por três vezes o cálamo caiu dos meus dedos, por três vezes a Musa

Negou-me as palavras, por três vezes ela abandonou os versos

[começados.

Por três vezes eu tentei conter as lágrimas, por três vezes elas

Escorreram mais abundantemente de meus olhos inchados.

Finalmente, quando as lágrimas permitiram, mas ainda chorosa, ela começou a

[falar,

Com a voz trêmula pelos suspiros convulsos.

Observa a grafia ilegível e mal-acabada das palavras!

Observa quão muitos borrões em muitos lugares!

Perdoa minhas lágrimas (elas, Catherine, merecem perdão)

Se esta carta não for inteiramente digna de teus olhos.

Ambos viemos para cá, creio, por desejo do destino:

Cada um de nós, descontente, deixou o solo pátrio.

Beja é minha pátria, fora Pax Iulia para os antigos:

Júlio César concedera a este lugar ter o seu nome.

Três irmãos eu vi, três irmãs me viram: 
O último rebento de tua progênie, mãe, fui eu.

A França, florescente nos estudos graças a um ócio menos glorioso, se apoderou [de três deles,

E eu próprio, como quarto, me juntei aos três.

A populosa Paris prendeu-me por sete anos,

E a mim, que crescia, instruiu-me nos estudos liberais.

Meu avô, porém, havia me consagrado à guerra desde os meus primeiros

[anos,

Para que ele tivesse um sucessor de sua glória.

Mas meu Marte era outro, as guerras eram outras, outros os acampamentos,

Outro viria a ser o objetivo de minha luta.

Depois de lá, o litoral de Bordeaux, que descreve um arco falciforme,

Me acolhe: para cá meu irmão viera anteriormente.

Aqui, novamente, abraço as Musas com todo o meu ardor:

Aqui, pela primeira vez, Diana foi vista por meus cães.

Daqui, depois de várias cidades, a predestinada Avignon

Me acolheu, cidade inexorável por decreto do meu destino.

Famosa, ela, pelos homens, e famosa pelos altos muros,

Mais famosa pela fama de tua beleza.

Assim que essa notícia chegou aos meus ouvidos,

Senti que meu peito foi assaltado pelo fogo.

Ai! Quanta terra, quanto mar rasguei,

Para acabar capturado por teus ardis, como um despojo

[estrangeiro?

Aqui chegando, Catherine, perguntei teu nome e qual a tua cidade natal,

Quem eram teu pai e teus avós, qual a origem de toda a tua família.

Tua candura imaculada havia gerado teu bom nome famoso

E, ademais, teu pai descendia de reis.

Um desejo insensato de ver-te invadiu-me, infeliz:

Decerto, para que eu me ferisse com minha visão.

Assim que te vejo, me perco: e, instantaneamente acesa, essa brasa

Redobra e multiplica as suas forças.

Foi por isso que te deixei, célebre Paris, 
E abandonei, desvairado, os lagos aônios.

Foi por isso que desprezei Bordeaux e a ilustre Toulouse,

E busquei uma nova cidade.

No entanto, ver-te, porque assim determinou o destino, foi inevitável:

E não pude não me perder, depois de ver uma deusa.

Tu também sentiste esse fogo, se ao menos quiseres confessar a verdade, 55

E meus gracejos com freqüência deram-te alimento para ele.

Oh, quantas vezes minha língua se paralisava dentro da boca

E, no lugar da língua, só me restava um fogo reluzente?!

No lugar da língua, gemidos, lágrimas, suspiros sem fim?!

O que se pode fazer? Cruel, o amor refreia as palavras.

E então, querendo agradar-te de todos os modos,

Passei a exibir os sinais do meu talento.

Por seis meses inteiros prendi a atenção dos sábios:

E a fama não foi desfavorável ao meu talento.

Mas se por acaso minha obra agradou a alguém,

O reconhecimento deve ser inteiramente atribuído a teus méritos.

Qual é a necessidade de palavras? O fato é que eu amei de modo bastante

[insensato.

Tu bem sabes como não é fácil disfarçar o amor!

E não digas, por favor, que é fácil; é bem possível que desejes dizer que é fácil.

Ai de mim! Como eu gostaria que tu pudesses com razão dizer

[isso!

Aliás, eu bem teria gostado que tu, Catherine, desejasses dizer isso,

Assim minha carta mentiria para ti.

E então, o que mais eu teria esperado que se acrescentasse ao meu destino?

Eis que surge em minha vida uma nova determinação.

Aonde, Deuses, aonde, afinal, aonde me enviais? Irei

Para bem longe daqui sem ti, Catherine? Sem ti?

Foi por isso que, lançado por terra e por mar,

Neste local decidi enfim me estabelecer?

Ai! Que crime cometi? Que leis divinas, que deuses eu, desvairado,

Não respeitei nem agradei? 
Oh! pudesse eu, quem dera, descrever-te meus sentimentos:

Sentirias como é verdadeiro o meu amor.

Sentirias minha dor, e verterias lágrimas, condoída,

Ainda que, perto das tuas lágrimas, meus males não sejam nada.

Talvez venhas a dizer: se Gouveia tivesse me amado,

Teria, com suas preces, alterado o destino, teria convencido Júpiter.

Não teria sido obrigado a buscar outra terra pelo mundo,

Não teria sido levado a novamente cortejar outro amor.

Crê em mim, Gouveia te amou antes mesmo de te ver,

E lutou para alterar seu destino com preces.

Porém, ele será obrigado a buscar, infeliz, outra cidade pelo mundo,

Mas não será levado a cortejar outro amor.

Quaisquer que sejam as regiões onde os Deuses me colocarem e me

[recolocarem,

Qualquer que seja a família de que devo, infeliz, me aproximar,

Assim como fui teu, ainda quando não havia te visto,

Da mesma forma serei, por todo o tempo que restar, teu.

Quer - que os Deuses não o permitam! - eu continue a viver,

Quer um túmulo estrangeiro cubra meus ossos. 


\section{SEGUNDA CARTA}

\section{DE CATHERINE A GOUVEIA}

Quando será que poderás sensibilizar-te com minhas lágrimas?

Quando será que darás, Gouveia, as mãos como vencidas?

Iludiste a mulher que te ama e que nunca te enganou.

O amor é algo pleno de uma credulidade imprudente.

Minha candura é que me induziu a isso. Não estou sendo punida em

[conseqüência de um defeito, portanto.

Ou será que ela não é mais digna de tua admiração?

Quantas vezes disseste: Eu vou deixar-te, Catherine?

Antes disso o teu Sena reverterá o sentido das águas!

Mas não te bastou dizer isso: tua palavra foi tomada por verdadeira sob o

[testemunho de Júpiter!

Que ele seja, eu imploro, o vingador de tua traição!

Sena, para onde estás correndo? para onde ides, verdes ondas?

Outra terra foi procurada por esse homem pérfido.

Nasceu-lhe também outro amor, e ele não é mais tocado pela antiga chama:

Que ele novamente viole essa outra aliança que acabou de selar.

Oh, tomara que a profundeza da terra se abra para ti, maldito!

Ou que Júpiter te queime com o fogo de um raio enviado por ele,

Ou que uma onda mais surda do que tu te engula num turbilhão,

Traidor, e que ela não ouça teus gemidos!

Que tu alimentes com teu corpo impuro toda espécie de peixes,

E que a água, depois de longo tempo, vomite teus ossos!

Que eles sejam espalhados, aqui e ali, na fulva areia,

E que não haja ninguém que se preocupe com que eles sejam

[cobertos com a reverência de um túmulo!

Que estou pedindo, infeliz? Prefiro que tu vivas, prefiro. 
Mas que tua vida seja, no entanto, mais triste do que a morte!

Que vivas como um forasteiro, sem glórias, numa cidade desconhecida: 25

Que tua sorte seja, ademais, detestável!

Que o mar te negue caminho, e a terra desconhecida, o aplauso!

Que as terras te tragam muitas ameças, as águas muitas mais!

Que sejas desgraçado! Que riam de ti na desgraça e pisem em ti enquanto

[estiveres caído,

Se ainda houver aqueles que sejas capaz de agradar com teus

[favores.

Que sejas desgraçado, e somente eu tenha pena de ti:

Que eu me comova e padeça com teus males.

E que todos os deuses, mesmo os que tu não tiveres incomodado com nenhuma

[ofensa,

Conjurem para te prejudicar.

Quando tiveres suportado tudo, que tua culpa seja mais leve que o crime de que

[te acuso, 35

E que possas declarar que te reconciliaste com Júpiter.

Deuses do mar e da terra, Deuses que presidis o céu de Júpiter,

E os que regeis a água pela qual jamais se perjurou:

Acedei e apoiai, vós todos, minhas preces!

Minha ira, muito justa, cumpriu seu papel.

Vieste com o propósito de que pudesses deixar minha pátria

E de que abandonasses uma mulher consumida pelo fogo.

Demofonte, levado no oceano por diferentes desvios de rota,

Entrou no teu porto, trácia Fílis.

Entrou e, recebido por ti em teu reino e em teu leito,

Entregou as velas e a fidelidade ao rápido vento Noto.

Teseu enganou a filha de Minos, e Jasão a ti,

Hipsipile, ambos pouco agradecidos aos favores recebidos.

O frígio fugitivo, e desertor da desgraçada Ásia, a Elissa;

E a ti, jovem habilidosa na lira, o teu Fáon.

Iludiste tu a mim, para que não pensem que não sou mulher.

Este sempre foi o destino de meu sexo. 
Mas minha condição é pior, porque tu bem sabes, traidor,

Que eu, infeliz, não obtive nenhuma alegria de ti.

Estavas resolvido a ir embora, resolvido a abandonar-me, infeliz,

Enquanto o amor falaz se insinuava em mim.

$\mathrm{O}$ amor tardio inflama a alma de modo muito mais inclemente,

E compensa a demora com a força da paixão.

Eu te peço, por estas lágrimas que aliviam meus males,

Por algum sentimento humano que porventura exista em teu

[peito:

60

Preocupa-te em descobrir qual é o remédio de que a minha ferida necessita,

Ou de que maneira pode cessar a dor dessa ferida.

Estás preocupado que eu espere por ti, que partiste para não voltar?

Com certeza, esta deve ser a única preocupação de tua fidelidade.

Alado Amor, se os assuntos dos mortais alcançam a ti,

Alado Amor, freqüentemente invocado em minhas preces,

Alado Amor, persegue aquele foragido por terra e por mar!

Que ele sinta que os Deuses, irados, têm poder!

Que ele arda com uma chama nova: a antiga chama já não o aflige.

Que ele queime, e alimente uma ferida secreta em seu peito!

Quando a notícia desses fatos, Gouveia, chegar aos meus ouvidos,

Nada me será mais desejável que uma morte tranqüila. 


\section{TERCEIRA CARTA}

\section{DE GOUVEIA A CATHERINE}

Estás aguardando que eu te envie uma saudação, Catherine?

Ai de mim, ninguém pode enviar o que lhe falta.

A lua já se escondeu quatro vezes - de fato, o tempo não me passou

$$
\text { [despercebido - }
$$

E meus olhos não viram tuas palavras em resposta.

Que esquecimento conseguiu apoderar-se de tua mente?

Há pouco eu era teu, tu eras minha senhora.

E não exigi, para mim, suaves beijos, ao preço da minha liberdade:

Dificilmente alguém foi levado a julgar que minha vida valesse tanto.

Não pedi teus abraços, ao atrevido Íxion as rodas violentas

Dilaceram e despedaçam ao meio.

Esta tua nobreza, tua conduta de uma vida sem mácula,

Esta tua beleza, estabeleceram os limites de meu comportamento.

E quem me dera tu não tivesses nem formosura, nem antiga

Nobreza, nem tua conduta impecável.

Eu teria vivido, com certeza, muito mais feliz: nem tu serias

Para mim uma senhora, nem, para ti, um escravo eu seria.

Já não sou mais teu, nem tu mesma me tratas como um dos teus?

Por qual crime meu pude deixar de ser teu?

Se, na tua opinião, meu amor se desvaneceu em poucas horas,

Por que não sou digno de teu caráter, Catherine?

Quanto a mim, esse longo intervalo de tempo redobra o fogo que me queima,

E o tempo e a hora multiplicam minha chama.

Foste tu que deste lágrimas sem fim para minhas lágrimas?

Foste tu que uniste as seguintes palavras à minha fala? 
Tu és capaz de te separares de mim? Abandonarás, ó fugitivo, tua

[senhora?

Então era este o fim de um falso amor?

Por que eu, infeliz, sempre te amei, por que tu sempre me amaste?

Diz, onde a minha fidelidade? Diz, onde o meu amor?

Estas palavras - se não me engano, e se não estou sendo crédulo demais em [mim mesmo -

Eram o testemunho de um amor nada oculto.

Eram o testemunho de um amor: isso, pelo menos, pára de negar!

Um amor tão puro não deve ser dissimulado.

E tua língua (bem recordo) nunca conseguiu nem suportou me dizer

$\mathrm{O}$ último adeus.

Agora, se a aparência injusta da minha condição de vida

É desprezada por ti, estou sendo eu castigado por um crime do acaso.

Todavia, as injustas mazelas de minha sorte não devem ser desprezadas,

Mas, ao contrário, devem ser sentidas com dor.

Elas devem ser sentidas com dor, pelo menos, e consoladas com lágrimas:

Isso era próprio da tua piedade e da tua obrigação.

No entanto, somente a sorte me falta, não uma alma mais elevada que todo

[acaso,

E mais dura até que os duros males.

Não me falta uma vida burilada pelos mais nobres estudos,

Não me falta um prestígio favorável ao meu talento.

Não me falta a nobreza transmitida pelos avós e bisavós,

De cuja linhagem eu fui feito o sucessor.

Não me falta (e é com isso que me reconforto) uma juventude vigorosa e

[saudável,

Nem a esperança de atingir posições magníficas e de difícil acesso.

Somente a sorte me falta, Catherine: mas ela

Não fica parada nem permanece para sempre num único lugar. $\quad 50$

Atingi a mais ínfima condição, admito: de um lado a humilhante pobreza,

De outro a vergonha, de outro ainda o cruel amor pelejava em

[batalha contra mim. 
Há, porém, nisso, razão para que me ames, não há razão para que possas me [desprezar.

Endimião era pastor, e pastor Adônis.

Quando Páris pastoreava os carneiros no monte Ida,

Era pobre, e uma ninfa era esposa de um pobre.

Nada assim eu peço: apenas junta-me ao número dos teus:

$\mathrm{Eu}$, perante ti, serei devedor desta vida.

Ou será que não foi o esquecimento de mim que te dominou,

Nem que desprezaste a aparência vergonhosa de minha sorte?

Será, então, que tu suspeitas que eu desejo outros amores,

E ofereço meu pescoço cativo a um novo jugo?

Esse motivo é certamente compreensível, e pleno de um amor sagaz:

No entanto, ele tinha de ser baseado em algum sinal dado por mim.

Minha alma não tem essa disposição, nem minha situação atual

[pede amores,

Nem nos infelizes se esconde um novo amor.

Aliás, quem dera o meu modo de vida fosse conhecido

Por ti, eu estaria livre de tal suspeita.

Estou vivo, mas odeio a vida, a luz e as pessoas:

E fico pensando que um resto de vida foi deixado para mim, apenas para

[que eu me desmanche em lágrimas.

70

Lamento que o sol demore a ceder seu lugar à noite,

Pois é em lágrimas que passo e gasto o tempo.

E quem dera meus olhos, Catherine, deixassem de lágrimas

E cessasse esta minha vida destruída por tão grandes males.

Oh, quantas vezes considero esses breves meses como se fossem anos!? 75

Quantas vezes uma hora passa mais lenta que o longo dia!?

Quantas vezes chamo a morte, covarde e lenta!?

Oh, quantas vezes ela foi surda às minhas preces!?

Somente a Musa, consoladora de minhas aflições,

Refreia, prestativa, as minhas lágrimas.

Com poemas ela alivia e interrompe a minha dor,

E com a loquacidade possível reconforta minha alma. 
Dizem que, levada Briseida, o triste Aquiles

Conteve as lágrimas com a lira trácia.

Quando Orfeu arrastava as árvores em direção às ondas do desértico

[Estrimão,

Sua esposa Eurídice já lhe tinha sido duas vezes arrebatada.

Enquanto Ovídio vivia exilado no litoral de Tomos,

Sentia falta dos recursos da mesma arte pela qual se arruinara.

Presta atenção para não inventares delírios falsos para ti mesma,

E assim eu acabar condenado por uma falsa acusação.

Ai de mim, não tenho nenhum espaço para um futuro amor,

Nem meu coração está sofrendo uma nova ferida!

Talvez o que receies seja isto (uma vez que nada aconteceu): ou que não seja

Doce, para mim, a tua doçura, ou que não seja doce, para ti, a minha.

Não sou nada doce, admito, ao passo que qualquer coisa amarga,

$$
\text { [vindo de ti, }
$$

Torna-se doce, e eu encontro conforto em meus próprios males.

O que se pode fazer? Cupido rouba o bom-senso e a razão:

O Menino ardiloso disfarça seu veneno com mel.

Invoco em testemunho estas lágrimas que fizeram tantos borrões,

Invoco em testemunho estes mesmos sinais, confidentes da minha

[alma, 100

Invoco a ti e a teu nume, mais presente em mim do que qualquer outro,

Para confirmar que, quer queiras, quer não, eu sou teu, Catherine.

Eu fui teu, mesmo quando não tinhas sido vista por mim,

E serei, por todo o tempo que restar, teu,

E assim permanecerei, enquanto a vida durar. Feliz

Me parece aquele, seja quem for, que pôde morrer amando. 


\section{QUARTA CARTA}

\section{DE GOUVEIA PARA CATHERINE}

LÊ ATÉ O FIM! Por que hesitas? Por acaso te impede um novo ardor?

Esta carta que se apresenta a ti não foi escrita por uma mão hostil.

Observa os borrões, sinais de minhas lágrimas,

E as palavras que de nada valerão a seu dono.

Gastar palavras à toa, todavia, é um bem para os infelizes,

Assim como procurar ajuda para o seu problema, mesmo sem esperança.

Minha mãe, Inês, mal me carregara por seis meses

E eu mal tinha algum sopro de vida,

Quando, durante a noite, ela teve este sonho.

Ai de mim, aquele não era um medo típico das mulheres!

A mim, distante da pátria, um menino me traspassava com sua flecha.

Ele era cego, se devemos acreditar em minha mãe.

Ah, mãe, foste uma profetisa por demais verdadeira para mim!

Eis, no peito traspassado a flecha permanece!

Eis, a pátria está distante, vós, amigos, estais distantes,

Eis, se ausenta a terra hospitaleira para minhas lágrimas!

Oh, quem me dera eu nunca tivesse rasgado a vasta superfície do mar,

Nem entrado no teu porto, ó terra francesa!

Não morreria, Catherine, depois de te conhecer e ver:

Nem tu terias sido vista por mim, nem eu visto por ti.

Nem o cruel amor — que menino, afinal, teria sido aquele? -

Teria alvejado com seus dardos o meu coração amoroso.

Por que me queixo? Ou ainda, quem sou eu? O arranjo inexorável do destino

Era esse: ele tem autoridade sobre os nossos senhores, os deuses.

Meu espírito, suporta e resiste! Não és cúmplice desse erro!

Quando houver algo que mereças sofrer, apenas nesse caso, sente dor. 
Não foi por mim ferido o Amor, não foi desprezado o poder de sua Mãe,

Não sou eu o autor do crime do filho de Tideu.

Não abandonei os estandartes dados sob o comando de Cupido: sempre,

Sempre foi ele o comandante de minha luta.

Não recusei, dia e noite, os trabalhos

Pelos quais o Menino não me demonstrou nenhuma gratidão.

Aqui, se a culpa é minha, e pela culpa sou castigado, então

Já passo a duvidar se devo considerar que os deuses são justos.

Pára, Cupido, de culpar os infelizes por tal crime:

Não convém ser hostil aos teus poetas.

Diz-me, o que fiz, senão que sempre bem amei?

Desse crime é que posso ser réu.

$\mathrm{Tu}$, Catherine, podes defender minha causa:

A pureza de meu coração é por ti conhecida.

Ainda que sejas injusta, e que a clemência não te mova,

Eu tinha a esperança de conseguir vencer no teu julgamento.

Pobre de mim, sob que tipo de juiz defendo minha causa!

Observa que credibilidade a própria causa me dá!

A ti nem o cumprimento ininterrupto de meus deveres,

A ti nem meu casto amor, nem minha fidelidade impecável,

Nem a persistência mantida por mim em várias circunstâncias,

Nada disso te persuade. Ao menos não desejes me esquecer.

Isso será o suficiente para mim, infeliz (e nem sequer peço para ser

[amado por ti!):

Que tu me odeies, mas que o motivo desse ódio seja unicamente

[o amor.

Observa sob qual lei estou disposto a te servir,

Enquanto este meu espírito viver numa demora detestável.

Mas, pensando bem, quem pode impor uma lei ao amor?

A quem ele não controla com suas ordens?

Portanto, ainda que me odeies, que me esqueças completamente até,

Sou teu, e permaneço, por todo o tempo, teu.

Posso ser teu, ainda que lutes ferozmente contra isso: 
Mas, que eu seja chamado de teu, tu, somente, podes conceder.

Não mereci, admito: por não haver merecimento, é maior a tua boa-vontade

$\mathrm{E}$, igualmente, se amplia o altar que ergo para louvar tua

[bondade.

Tem piedade da minha intensa juventude, que ela não pereça antes do tempo

E que meus ossos não sejam cobertos por terra estrangeira.

Tem piedade de meu talento: há pouco começou a me tocar

Um desejo sóbrio de prestígio eterno.

E, para que os pósteros lessem teu nome depois da tua morte,

Muitas vezes invoquei a Musa em teu louvor.

Dar-se-á, talvez, que as obras de meu trabalho literário vivam

E caiam nas mãos da distante posteridade,

E minha página se torne o testemunho da tua virtude.

Crê em mim, somente os poemas escapam do tempo.

Se, contudo, não tens piedade de mim, tem de minha mãe:

Fui o último rebento de sua progênie.

Três filhos lhe nasceram, aos quais a França retém, todos,

E ela não tem com que diminuir a saudade:

Sozinha, numa casa viúva, se entristece, privada dos filhos e do pai.

Vai agora, e que sejas apontada como a causa da minha morte!

Ainda que ela esteja distante em terras lusitanas,

A notícia de um mal é uma mensageira demasiado veloz.

Mas se, por acaso, meus males fossem capazes de alegrar-te,

Com certeza seria doce suportar tudo o que eu sofresse.

Se, porém, a ti nenhuma desgraça alheia alegra, realmente

Não há nenhuma necessidade de despejar as palavras ao rápido

[vento Noto.

Usa do teu direito, pois assim infligiu o destino:

Arranca a única coisa que me resta, a vida!

Irei ao encontro das almas infelizes que, se muito não me engano,

O implacável Amor devastou com uma paixão cega.

Irei, e comigo estarão, no mesmo bosque,

Hipsipile, Dido, Laodâmia, Prócris. 
Irei, e todos juntos misturaremos as lágrimas.

Crê em mim, esta era uma virtude do teu sexo!

Tão logo viu a frota troiana avançar com as velas,

Dido, em pessoa, tombou ferida por sua própria mão.

Viu Hero ao jovem de Abidos jogado pelas ondas,

E, no mesmo instante, lançou-se nas águas turbulentas.

O que falar de Tisbe? O que de ti, ó Pórcia, digna de Catão, teu pai?

O que, casta Árria, de tua espada?

O que de Prócris, de Hipsipile, de todas as demais Heróides,

Em relação às quais tu és maior em sangue, em glória menor?

Eu vi homens receberem magníficas recompensas em troca de um falso amor,

Ao passo que meu amor será brindado com a morte.

100

Meus ossos serão cobertos pela terra, quando o espírito abandonar meus ossos,

E no mármore do sepulcro haverá este dístico:

$\mathrm{Tu}$, seja quem fores, que quiseres saber a causa de minha morte

E qual é a extensão de meu crime: era amar. 


\section{ANTÔNIO DE GOUVEIA A JACQUES DE BEAUNE. SAUDAÇÕES.}

DIZ-ME a verdade, não é assim Ovídio? Foi o meu propósito, sem dúvida: mas se, ou por esforço, ou por talento, tive êxito, então perfiz algo grandioso e até inacreditável aos homens de minha época. Ou será que, de fato, ele é mais culto, intrinsecamente mais fluente, e mais versátil? Não me enfeites nada: prefiro um testemunho do teu reconhecido discernimento a um da tua benevolência. Se estes poemas forem dignos do teu paladar, eu os oferecerei a ti quando puderes satisfazer teu apetite com eles. ADEUS. 


\section{Capítulo 6}

\section{NOTAS E GOMENTÁRIOS}

\section{NOTAS E COMENTÁRIOS A \\ EPIGRAMMATON LIBRI DVO (I539)}

\section{Capa e folha de rosto}

EPIGRAMMATwN: No título da obra, Gouveia usa a desinência grega do genitivo plural da palavra "epigramma", inclusive com o emprego, no incipit, da letra grega ômega, em vez da forma latinizada "epigrammatum", certamente por influência e imitação dos títulos de obras clássicas, como as de Virgílio (e.g., Georgicon) e Marcial (Epigrammaton) ${ }^{190}$. É de notar que, no interior da obra, Gouveia não repete o uso da letra grega, preferindo ora a forma "epigrammaton" (para indicar, restritivamente, o título de seu livro), ora a forma "epigrammatum" (como simples genitivo plural da palavra "epigramma"), no interior dos poemas I, 28 e 48.

SUN THI HMERAI: expressão em grego, equivalente a "cum die" em latim, literalmente "com o dia", isto é, "juntamente com o dia" ou "conforme ao dia", um reforço da dedicatória anterior, à mortalidade, no sentido da efemeridade da vida humana.

Lugduni: locativo de Lugdunum, forma latina do nome da cidade de Lyon, na Sabóia francesa.

Sebastianum Gryphium: forma latinizada do antropônimo Sébastien Gryphe, um dos mais importantes impressores da Renascença européia; de uma invenção tipográfica sua, para realçar o texto, é que provém o verbo "grifar".

${ }^{190}$ Cf. Allen, § 83, g. 
Carta introdutória a Jacques de Beaune

Esta carta-dedicatória a Jacques de Beaune, em forma de prefácio aos poemas, cumpre a função tradicional dos textos introdutórios da literatura latina clássica, imitada pelos poetas renascentistas, de estabelecer uma poética própria do autor, a "cartilha" de princípios estéticos e, mais restritamente, poético-literários, que o autor segue e defende.

No caso de Gouveia, temos, no primeiro parágrafo ${ }^{191}$, a sustentação de que a atividade literária é resultado de três elementos: antes de mais, o animus e a facultas (ad scribendum), isto é, a "vontade ou disposição" e a "capacidade ou habilidade", sucedâneos, aqui, do clássico binômio "ingenium et ars", "engenho e arte", ou "talento e técnica". Portanto, é preciso, primeiro, uma vontade ou disposição natural, um impulso em direção à escrita, até uma certa coragem para fazê-lo em público; mas também é necessária a capacidade, o domínio técnico, que, ainda que nascido na ignorância, é fundamentalmente fruto do exercício, da preparação (exercitatio).

O terceiro elemento pode parecer acessório, mero agradecimento algo bajulatório ao apoio dos amigos, mas, se considerarmos o contexto da produção literária da época, veremos que não se trata apenas disso. De fato, uma característica marcante do movimento humanista foi justamente a promoção de círculos literários, espaços de circulação e discussão de textos, sustentando uma verdadeira República das Letras (termo em voga no período, não por acaso utilizado por Gouveia no prefácio de 1540), por onde uma elite intelectual transitava, divulgando os tesouros artísticos e literários de uma "nova era" do conhecimento. Trata-se de um período em que se pratica largamente a alusão literária, e devemos reconhecer que a intertextualidade é elemento constitutivo da literatura renascentista. Os efeitos dessa busca de inserção na comunidade intelectual são perceptíveis na própria literatura: basta ver, em Gouveia, a quantidade de epigramas destinados a outros poetas contemporâneos, e que devem ser compreendidos à luz das citações que fazem a versos desses poetas. Portanto, o diálogo entre os poetas é, também, um ponto de partida fundamental para a publicação de um livro.

No segundo parágrafo, essa idéia será distendida, e Gouveia falará justamente desse diálogo intertextual essencial à produção poética, que remeterá naturalmente ou aos antigos

${ }^{191}$ Cabe observar que o texto original não está dividido em parágrafos, devendo-se a presente divisão à edição do texto proposta no âmbito da pesquisa. 
(os modelos clássicos) ou aos novos (os grandes sucessos contemporâneos). Esse segundo parágrafo é inteiramente construído em pares simétricos, num equilíbrio cuja fonte não é difícil de atribuir a Cícero. O pilar sobre o qual se sustenta toda a estrutura do parágrafo é a dicotomia entre escritores novos e antigos (veja-se, logo no início, nouos et ueteres scriptores), daí decorrendo a contraposição entre "inovação ou novidade" (nouitas) e "tradição ou antiguidade" (antiquitas).

Título:

Iacobo Belnaeo: acolheu-se a identificação do nome latinizado Iacobus Belnaeus como sendo Jacques de Beaune, conforme proposta do historiador Luís de Matos ${ }^{192}$.

Parágrafo 1:

recolligerem: o verbo latino indica não apenas "recolher-se" ou "afastar-se" de uma dada situação, mas conota o aspecto de "recuperar-se de uma atividade estafante", "recobrarse de uma doença”.

argute: a característica mais marcante e a qualidade mais almejada dos epigramas, diante da sua reduzida dimensão, é justamente a agudeza.

epigrammate concluderem: de maneira geral, o verbo concludo traz a idéia primeira de “alocar ou dispor dentro de determinados limites", e, por decorrência, "concluir, finalizar"; é muito comum na prosa ciceroniana, sobretudo neste segundo sentido, e vem com certa freqüência acompanhado do termo sententia, indicando, na preceptiva retórica, a idéia de "concluir ou resolver um período discursivo"; a construção de Gouveia, com duplo complemento no acusativo e no ablativo, é utilizada nos clássicos no sentido de "confinar ou restringir algo em determinada área"; é rara na poesia, aparecendo apenas uma vez em Horácio em sentido técnico, aplicado a uersum; na passagem de Gouveia, seria algo como "transportar determinada matéria poética para os limites artísticos do gênero epigramático", "dar-lhe a forma de epigrama", "enquadrá-lo na forma de epigrama”.

praesertim cum: locução conjuntiva muito freqüente em Cícero (177 ocorrências, mesmo sem incluir a inversão “cum praesertim”), raríssima na poesia (uma vez em Horácio);

\footnotetext{
192 Matos, Sobre Antônio de Gouveia e a sua obra, p. 23.
} 
segundo o DLF, seguida de subjuntivo, adquire valor explicativo ou causal: "sobretudo diante do fato de que".

animus: termo polissêmico que admitiria várias traduções pertinentes, como "vontade", "desejo", “interesse", "coragem” ou mesmo o cognato "ânimo"; com efeito, animus como "sentimento ou disposição" é um sentido decorrente da noção primeira de animus como centro corporal das disposições mentais e passionais do ser humano, um núcleo abrangente, que abarcaria termos usados hoje em dia, como "mente", "coração" ou "peito".

facultas, quam usu quidem litterarum prope nullo partam: facultas é "capacidade", "facilidade para empreender algo", "habilidade", "skill" (Lewis), "os meios ou recursos necessários para uma tarefa”. Outro sentido dessa palavra, apontado pelo DLF e pelo OLD, é o de "talento", e é possível que esse sentido esteja acoplado ao termo em questão, uma vez que, na seqüência do texto, Gouveia afirmará que essa habilidade ou capacidade para escrever nasceu-lhe já nos primeiros contatos com a literatura. Ainda assim, cabe lembrar que, logo a seguir, Gouveia dá a entender que, sem o exercício dessa habilidade, isto é, sem o cultivo e o domínio da arte literária, não se torna escritor. Em relação ao trecho, considerou-se usu litterarum prope nullo como ablativo de origem, sem preposição, complemento do particípio verbal partam (“nascida, gerada, produzida"), cf. Ernout, parágrafo 105, e Allen, parágrafo 403, a.

accederet inani fortasse spe, incensa tamen, ac inflammata exhortatio: o verbo accederet está empregado em construção absoluta ("juntava-se", “acrescentava-se"), pois, construído com complementos, rege dativo, e não ablativo, que é o caso de spe. Portanto, inani spe seria um ablativo indicando circunstância concomitante; parece-nos que, de todo modo, incensa e inflammata estão no nominativo e qualificam exhortatio, e não no ablativo, adjetivando spe; somos levados a isso pela presença da conjunção "ac" e pela carga semântica dos adjetivos, mais próximos, desse ponto de vista, de exhortatio do que de spe.

\section{Parágrafo 2:}

hoc genere: refere-se ao gênero epigramático.

nescio quomodo: expressão idiomática do latim, marca de indefinição: "de algum modo", "de certo modo", "um pouco".

non displicere: litotes, de valor amplificativo.

plurimum: pela posição da palavra e pela simetria do parágrafo, considerou-se que plurimum se liga a intelligerem, como advérbio. 
quorum altero: trata-se de um trecho de interpretação complicada, pela dificuldade de identificar nitidamente os termos aos quais se referem os pronomes quorum e altero; talvez seja por isso que Gouveia excluiu esta parte final do parágrafo da nova edição de 1540 . Pelo desenrolar da argumentação do trecho, consideramos que o pronome relativo quorum retoma apenas o pronome demonstrativo hos, isto é, "os antigos escritores", e não o conjunto dos escritores (velhos e novos); nessa mesma linha de interpretação, a correlação altero ... altero não faz retomada anafórica dos pronomes illos e hos, isto é, não faz referência a novos e velhos escritores, respectivamente, mas a "um" e "outro" dentre os antigos escritores, sinalizando, assim, em caráter catafórico, a oposição que virá a seguir, entre Catulo e Marcial. Também pesou para esta interpretação o fato de Gouveia haver utilizado o pronome alter, que costuma se referir a "um ou a outro de dois", e é raramente empregado para se referir a grupos e, neste uso, seria de esperar que aparecesse no plural, embora não seja impossível o uso do singular em função de sinédoque (isto é, novos e velhos escritores encarados como grupos).

Nesse sentido, discordamos da interpretação da estudiosa Maria Luísa Meireles dos Santos ${ }^{193}$ : em sua dissertação, ela considera que quorum se refere a todos os escritores, abrangentemente, ao passo que altero... altero os subdivide em dois grupos, o dos novos e o dos velhos; nesse sentido, a tradução passa a ser outra, pois Gouveia estaria a dizer que não poderia servir-se abusivamente dos escritores contemporâneos para forçar elogios ao seu trabalho, e não queria usar os antigos. Embora a interpretação gramatical seja aceitável (ainda que forçada), torna-se difícil entender o sentido que Gouveia pretende dar ao fato de não querer usar os antigos.

ad nostrorum laborum commendationem abuti non possem: segundo o Lewis e o OLD, a construção do verbo "abutor + ablativo + preposição $a d$ " e complemento no acusativo significa "explorar ou tirar vantagem de algo para alcançar algo", "fazer mau uso de algo com o propósito ou a intenção de"; preferiu-se aqui a tradução "abusar de" para manter a paronomásia entre abuti e uti, presente no texto; no entanto, cabe esclarecer que o que Gouveia modestamente afirma, em nossa interpretação, é não ser capaz de fazer um mau uso de um bom poeta, como Marcial, apenas para referendar sua própria poesia (e, quanto ao outro, Catulo, um poeta de qualidades inferiores, que não pode servir de modelos, ele próprio não deseja usá-lo).

\footnotetext{
${ }^{193}$ Cf. Santos, Antônio de Gouveia, Epigramas, Livros I e II, p. 37.
} 


\section{Parágrafo 3:}

inuenit: o verbo inuenio não significa apenas "descobrir", mas também, e parece ser o caso aqui, "propor pela primeira vez, inventar, imaginar de forma inédita"; considerando que Gouveia esboça nesta passagem uma crítica sumária à produção literária de Catulo, foi nesse sentido que interpretamos o verbo.

religionis metu: uma leitura mais atenta da carta leva à conclusão que essa expressão não significa, aqui, "medo da religião" ou "medo religioso", isto é, o humanista português não está entrando aqui nas questões religiosas, tão vivas no século XVI, nem está dizendo que a religião dificulta ou embaraça a interpretação dos clássicos. É bem verdade que poderíamos ser levados a entender dessa maneira, se nos prendermos ao contexto histórico, lembrando o cuidado e mesmo uma certa hostilidade com que a Igreja tratou a literatura clássica; entretanto, se observarmos meticulosamente a argumentação da carta, veremos que a interpretação é muito mais simples, e distante dessa: Gouveia diz apenas que, para avaliarmos com justiça uma obra clássica, é preciso afastar o excesso de reverência, é preciso despir-se do respeito ou da idolatria que impede que sejam tecidas críticas consistentes. Isso pode ser corroborado pelo fato de que religio não significa somente "religião", mas também "reverência" ou "respeito escrupuloso, consideração", ao passo que metus não significa apenas "medo", mas também "veneração, respeito excessivo, intimidação". Aliás, considerando que Gouveia critica e avalia negativamente Catulo, não faria nenhum sentido descartar a religião, pois os problemas de ordem religiosa no texto de Catulo até ajudariam a reforçar o ataque gouveiano; portanto, a única interpretação cabível é a que vincula religionis metu a um respeito ou veneração quasi religiosa pelos clássicos.

desideres: levando em consideração o contexto de forte crítica a Catulo, formulada por Gouveia, entendemos o emprego do verbo de forma restritiva, ou seja, Gouveia afirma que talvez não se sinta falta de nada de louvável em Catulo no sentido de que talvez não haja nada de desejável em sua obra, no que concerne à agudeza do espírito ou à pureza do discurso; portanto, numa paráfrase, não se dá pela falta de nenhuma dessas qualidades literárias em Catulo não porque ele as tenha na totalidade, mas porque ele não as possui de modo algum.

\section{Parágrafo 5:}

post multo laude: uma vez que post, enquanto preposição, rege acusativo, julgou-se que aqui se tratava do advérbio, modificando multo, também advérbio, e acompanhado de laude, ablativo de especificação (Allen, § 418). 
ad hanc quoque: literalmente, "aspirou também a esta", ou seja, também cobiçou a glória no gênero epigramático, o louvor pelos epigramas.

\section{PRIMEIRO LIVRO DE EPIGRAMAS}

CATHARINAM BOFREMONTANAM: Como bem assinalou o professor Carlos André $^{194}$, a questão da identificação de Catharina Bofremontana, destinatária de uma série de epigramas e das quatro cartas poéticas, continua em aberto. No entanto, em que pesem os importantes estudos de Joaquim de Carvalho e especialmente a minuciosa monografia de Joaquim Veríssimo Serrão, a defender que essa Catharina é a mesma Catherine Dufaur com quem Gouveia viria a se casar, em 1549, ainda julgamos ser mais consistente a argumentação exarada por Martha Katherine Zeeb, segundo a qual trata-se de uma certa Catherine de Beauffremont, do seio de uma família da nobreza da região do sul da França. Por esse motivo, e à falta de uma elucidação definitiva do problema, preferimos utilizar esse nome na tradução do antropônimo dos poemas, até porque é o que mais se aproxima, na verdade, do som do termo latino, e seria a mais provável latinização da forma vernacular francesa.

[2]

protinus: segundo o OLD, os sentidos de "para longe, direto a partir de, forward from" e "de imediato, de cara, immediately", costumam estar acoplados no uso do termo.

sua... manu: complemento do verbo excutiat (cf. OLD, sub uoce excutio), ablativo de separação.

Si licet, et fas est: a fórmula parece querer indicar apenas a idéia de que "se for possível, se houver condições, se for cabível”, embora recorra tanto a uma idéia de licença ou permissão social (expressa por licet) quanto a de uma autorização suprema ou divina (presente emfas).

[3]

${ }^{194}$ Cf. André, Mal de Ausência, p. 380. 
ANDREAM GOVVEANVM FRATREM: André de Gouveia, irmão de Antônio, foi diretor do Colégio da Guiena, em Bordeaux.

Miraris: o verbo carrega a noção de "admirar, olhar com respeito e admiração".

sollicitus: discordando da interpretação de Meireles dos Santos, acreditamos que o adjetivo refere-se ao destinatário do poema, André de Gouveia, sujeito oculto do verbo miraris: ele é que admira, sem invejar, a obra do irmão. A nosso ver, o gracejo do poema está, justamente, no paralelo entre a atitude de André olhar com admiração, mas sem inveja, o trabalho do irmão, e o fato de o livro (aqui, metonímia de Antônio), embora reconhecendo-se sem valor (genio sine), ao contrário do esperado, não estar contaminado pela inveja. Leve-se ainda em conta, para a compreensão do poema, a circunstância de Antônio ser mais novo e subordinado a André na hierarquia do colégio.

genio sine: repetição da parte final do verso, reforça o caráter de humildade do autor.

[4]

AVSONIVM: Ausônio, natural de Bordeaux, foi um poeta muito apreciado pelos humanistas, readquirindo, durante o Renascimento, um relevo equivalente ao que tivera na sua época e nos séculos imediatamente posteriores. Petrarca e Boccaccio conheceram sua obra, cuja circulação ampliou-se muito a partir de fins do século XV e especialmente a partir do século XVI. Foi aclamado por Vives e Erasmo, entre tantos outros, mas foi sobretudo na França que acabou elevado a um estatuto de grande modelo poético.

Cabe lembrar que Antônio de Gouveia passou muitos anos em Bordeaux, lecionando no colégio dirigido por seu irmão André, e, por outro lado, poetas com quem o português mantinha um relacionamento pessoal ou literário, como Hugues Salel ou Jules Scaliger, estavam entre os cultuadores do bordalês. Ademais, uma das edições mais difundidas dos poemas de Ausônio, no Renascimento, foi preparada por Élie Vinet, amigo pessoal de Gouveia; além dela, também há registro de uma edição de 1548, organizada por Gilbert Ducher, poeta do Humanismo citado mais de uma vez pelo autor lusitano.

Sendo assim, não é de espantar que Gouveia estabeleça um diálogo literário com Ausônio, nem que sua escolha tenha recaído justamente sobre um de seus epigramas mais conhecidos, aquele que abre sua obra epigramática e lança, programaticamente, os princípios estilísticos de seu conjunto de epigramas.

O dístico original é o seguinte: "Salua mihi ueterum maneat dum regula morum / Ludat permixtis sobria Musa iocis". Green, na edição completa das obras de Ausônio, defende 
a leitura de permissis em lugar de permixtis, por motivos estilísticos e por constar essa forma dos códices, mas ressalva que algumas edições trazem a palavra permixtis. Diante dessa observação, acreditamos ser provável que Gouveia tenha tido acesso, na sua época, a essa versão, adaptando o vocábulo para mixtis, em função da métrica e da introdução do verbo ais.

O poema completo de Ausônio, na versão de 1604, é a seguinte:

Nostra simul certant variis epigrammata nugis.

Stoicus has partes, has Epicurus agit.

Salua mihi ueterum maneat dum regula morum,

Ludat permistis sobria Musa iocis.

pereat quamuis: a conjunção quamuis rege verbo no subjuntivo, quando assume valor concessivo. O verbo pereat, por sua vez, indica um estado de perda já ocorrida; por esse motivo, apesar de estar no presente, admite a tradução por um verbo no passado.

Sordidulos: vocábulo raríssimo nos clássicos, não se registra em nenhum dos autores mais referidos por Gouveia.

[5]

IOANNIS BAROLLAE: Segundo Veríssimo Serrão ${ }^{195}$, trata-se de Jean d'Yberrolla, antigo conselheiro no Parlamento de Rouen, que passou a exercer a mesma função em Bordeaux, a partir de 1519. Também exerceu o cargo de Reitor da Universidade de Bordeaux, a partir de 1521. Faleceu em 11 de dezembro de 1537, o que motivou este epigrama fúnebre de Gouveia. Luís de Matos grafa o nome como "Ybarrola"196.

In quo certarunt: o verbo certo, no sentido de "disputar a primazia em determinado campo", constrói-se com complemento preposicionado "in + ablativo", que indica o campo da disputa.

[6]

PICA: "Pega", ave dos campos europeus, aparentada à gralha, e tida como barulhenta.

\footnotetext{
${ }^{195}$ Veríssimo Serrão, António de Gouveia e o seu tempo, pp. 53 e 82-83.

${ }^{196}$ Matos, op. cit., p. 24.
} 
IOANNIS CRVCEI PICARDI: Segundo Luís de Matos ${ }^{197}$, trata-se de Jean Lacroix, original da Picardia, cônego de Auch, que esteve em Bordeaux por volta de 1535.

loquax: "barulhenta, sonora, tagarela", adjetivo aplicado por Gouveia a essa ave da família das gralhas.

studium: "interesse, cuidado" e, por metonímia, "objeto da atenção".

Picardia ... dicta ... a Pica: há um jogo de palavras difícil de imitar na tradução, pois lida-se com a possível origem etimológica da palavra "Picardia", que seria proveniente de "Pica", isto é, do nome da ave "pega".

Crediderim: perfeito do subjuntivo do verbo credo, empregado para indicar uma afirmação atenuada; neste uso potencial, com a perda completa da noção de perfectum ${ }^{198}$.

Pici: "Picanço", ave de origem mitológica, associada a Marte, deus da guerra; daí Picus Martius, como costuma ser designado. Nas Metamorfoses, livro XIV, Ovídio descreve a transformação do rei Pico, filho de Saturno e pai de Fauno, num pássaro, por obra de Circe. A conjectura de teor etimológico proposta por Gouveia dificulta ainda mais a tradução, pois insere um novo jogo de palavras, entre Picus e Picardia; a tradução em português desse nome, "picanço", se afasta um pouco da paronomásia contida no original. Também é custoso manter na tradução a expressão do último verso, "Martia Picus auis", sua correlação com a sonoridade dos termos e, ao mesmo tempo, o substrato mitológico das associações feitas.

Martia gens: "povo marcial, guerreiro".

E Gallicis Marotti: Clément Marot foi um dos mais importantes poetas da França renascentista no século XVI. Participou ativamente do círculo literário humanista de Lyon e tinha contato com poetas como Bourbon, Visagier ou Ducher, que imitaram suas composições.

MARSIVM: Segundo Luís de Matos ${ }^{199}$, trata-se de um certo Marcis, membro de uma conhecida família bordalesa.

${ }^{197}$ Matos, op. cit., p. 24.

${ }^{198}$ Cf. Ernout, $\S 255$, c, que chega a afirmar: "le parfait est plus fréquent, lequel perd du reste toute valeur de perfectum”. Cf. Allen, § 446. 
BRIANDO VALLIO: Como demonstrou Serrão ${ }^{200}$, trata-se de Briand de la Vallée, senador do Parlamento de Bordeaux, mecenas do Humanismo e protetor do Colégio da Guiena, que teria feito o seguinte epigrama em resposta à invectiva do poeta português:

Antonii, genus hoc uestrum, Marrana propago,

In coelo et cellis non putat esse Deum.

cellas ... imas: entendemos aqui um uso mais específico do termo, no sentido de "adega ou cave", embora a expressão utilizada por Gouveia possa referir-se a qualquer porão ou depósito subterrâneo.

trepido: o adjetivo trepidus, derivado do verbo trepido, transmite a idéia de "assustado, em pânico", expressando em sinédoque o medo que Vallée sentia das trovoadas.

E Graeco Theocriti: Antônio de Gouveia verte para o latim o idílio XIX, atribuído anteriormente a Teócrito, mas hoje considerado, indiscutivelmente, espúrio, e apresentado costumeiramente dentre as composições reunidas sob a designação de Pseudo-Teócrito.

O título do poema original, também de oito versos, é Khriokle/pthj, isto é, "Ladrão de mel".

media: note-se a posição da palavra media, exatamente no meio do verso, entre duas palavras de cada lado, e a engenhosa substituição da mesma palavra pelo vocativo Teui, no terceiro verso, que reproduz o primeiro, com exceção dessa troca, deixando Teui (o destinatário) precisamente no meio do verso.

inuenisse: infinitivo passado, literalmente, "ter encontrado".

Nare ualere puto, mente carere puto: o sentido do verso, obviamente, é o de que encontrar uma comida escondida no meio de outras "é mérito do nariz, e não da cabeça"; esta

\footnotetext{
${ }^{199}$ Matos, op. cit., p. 24.

${ }^{200}$ Serrão, op. cit., pp. 53-56. Cf. Matos, op. cit., p. 24.
} 
seria a tradução utilizada, se não fosse calcada na versão de 1540 do mesmo epigrama. Cabe notar, ainda, que nare ualere pode ser entendido como "estar bem de nariz", considerando-se nare como ablativo de relação.

RIBALDO: Pela conclusão do epigrama, deduz-se que Ribaldus é a latinização do nome "Ribaud", adjetivo do antigo francês, hoje arcaico, mas comum na Idade Média; é um termo injurioso, equivalente a "méchant, débauché, pillard", isto é, "depravado, imoral, ladrão, celerado, desonesto ou, de forma suavizada, vagabundo". Aparece, por exemplo, nos Salmos de Marot (IX, 40).

Cura, labor, studium, deliciaeque meae: este verso consta da errata do volume de epigramas, sendo, originalmente, "Deliciae, domini cura, laborque sui". A nova escolha e disposição das palavras parece valorizar a afeição perante o animal, pois, da maneira anterior, após três palavras que indicam uma relação mais leve e agradável (amor, ioci e deliciae), havia, quase como desfecho, duas palavras que conotam preocupação e zelo atarefado (cura e labor). A refacção do verso acaba por colocar esses dois termos (acrescidos de studium) numa posição intermediária, e deliciae meae funciona como uma espécie de veredicto final, efetivamente elogioso, do cão.

[25]

IOANNEM BORDAEVM: Luís de Matos acredita tratar-se de Jean de Borda, "muito provavelmente bordalês". ${ }^{201}$

[26]

Antonii Alacris: trata-se do poeta e humanista francês Antoine Alaigre (ou Allègre), que viveu entre 1500 e 1570. É desconhecido o poema vertido por Gouveia.

uidisset scilicet: interpretamos a fala de Vênus como uma reação indignada, donde consideramos scilicet como uma expressão de reforço da indignação, algo como "quero dizer", "se é que me entendem", "por certo", "alto lá!”; o OLD indica, no quarto parágrafo do verbete scilicet, o uso irônico do verbo, na sugestão de algo sensivelmente impossível ou absurdo, assim como a utilização para chamar a atenção para a monstruosidade ou o absurdo

\footnotetext{
${ }^{201}$ Matos, op. cit., p. 24.
} 
de uma ação ${ }^{202}$. Quanto a uidisset, o emprego do perfeito do subjuntivo nos apontou tratar-se de um "irreal do passado". Por esses motivos, descartamos para o verso uma tradução do tipo "ele com certeza deve ter visto uma outra deusa", ou a proposta de Meireles dos Santos, "ele viu foi a Deusa"203.

SALMONIVM MACRINVM: Salmon Macrin (Jean Salmon, dito Macrin ou Maigret), um dos mais importantes poetas neolatinos da França renascentista, autor de vasta produção, que engloba hinos, epigramas, odes, elegias, etc. Viveu entre 1490 e 1557.

Ausoniae: Ausonia é o termo poético latino para referir-se à Itália.

lyra, salibus, flebilibusque modis: gramaticalmente, ablativos de relação, restringindo o campo onde se trava a disputa; não distante dessa análise, poderíamos considerá-los ablativos instrumentais, os meios com que se trava o combate. Semanticamente, referência, em metonímia, a três gêneros poéticos clássicos: a lírica (referida por lyra, instrumento musical que acompanhava a declamação dos versos "líricos"), a epigramática (referida por salibus, literalmente "os sais", isto é, "ditos jocosos ou espirituosos", "gracejos", "fineza de pensamento") e a elegia (referida por flebilibus modis, "metros plangentes", "versos lúgubres", característica original da elegia).

conaris: optou-se pela tradução "praticas", ao lado de outras possibilidades, como "te dedicas a", "tentas".

Alcides: Hércules, filho de Alceu; preferiu-se a forma mais conhecida da personagem mitológica a seu equivalente "Alcides".

[28]

\section{IOANNEM CRUCEVM:}

Argutis Epigrammatum libellis / Toto notus in orbe Martialis: Gouveia cita, em ordem invertida, dois versos de um dos mais conhecidos epigramas de Marcial, justamente o de abertura de sua obra, se é que podemos chamar assim, com alguma imprecisão, ao primeiro epigrama do primeiro livro. O primeiro verso, em Gouveia, corresponde ao terceiro, em Marcial, ao passo que o verso seguinte é o segundo em ambos.

\footnotetext{
202 OLD, p. 1703, sub uoce "scilicet", 4.

${ }^{203}$ Santos, op. cit., p. 57.
} 
Argutis licet usque et usque chartis: considerando, por um lado, que licet exerce, aqui, a função de conjunção concessiva, subordinando este verso ao seguinte, e estabelecendo um confronto entre ambos, e, por outro lado, que o advérbio usque, aqui duplicado, aplica-se a noções espaciais, Gouveia parece-nos ter conseguido tecer uma passagem de extrema agudeza, elaborando um notável contraste entre dois espaços: o espaço do livro, isto é, das páginas, versus o espaço do mundo, os extremos da terra. A idéia que nos parece por traz da construção é a da jocosidade produzida pelo fato de que, embora os poemas sejam argutos ao longo das páginas, isso não torna seu autor conhecido até os limites do mundo.

Concernente a usque et usque, cabe ainda comentar que a tradução "todas e todas" não é, evidentemente, literal, mas apenas procura repor a estratégia verbal do epigrama; uma tradução literal seria, talvez, "sempre e sempre", "continuamente", "para cá e para lá", "total e completamente".

Mendaci: complemento de arguis ("acusas"), é genitivo de relação (do substantivo mendacium, "mentira"), especificando o teor da acusação.

Hispanum tamen esse schema nescis: preferimos traduzir schema pelo sentido mais técnico de "recurso", "figura retórica", "procedimento textual", "estratégia argumentatativa". Cabe lembrar que Marcial é hispânico; portanto, a graça do epigrama consiste em desmascarar Lacroix, que finge ignorar Marcial, mas escreve do mesmo modo que ele.

[30]

lucentem ... lampada: lampada é acusativo singular, na desinência de origem grega da palavra lampas; a tradução, "lamparina acesa", dá conta de uma interpretação concreta da expressão, mas não se deve descartar um uso metafórico, no sentido de "luzeiro brilhante", a indicar o Evangelho, que seria encoberto por um instrumento de medida comercial; nessa interpretação, talvez Gouveia esteja fazendo uma referência indireta a um possível comerciante judeu, que ocultaria o Evangelho.

sanguis: literalmente, "sangue"; por extensão, "força, vigor".

honestatis: optamos por traduzir como "comportamento", ao lado da possibilidade de "condição, extração". 
Discite ... doceret ... facere: Gouveia forja, na fala do monge, três erros de prosódia: primeiro, ele alonga a sílaba "ci" de "Discite"; depois, abrevia a sílaba "ce" do verbo "doceret"; em seguida, prolonga a sílaba "ce" de "facere"; assim, "dīscǐtě", para manter a métrica do hexâmetro, se torna "dīscītě"204, "dŏcērēt", pelo mesmo motivo, no pentâmetro, se torna "dŏcĕrēt" e "făcěrě", igualmente, "făcērě". Diante da dificuldade da tradução, procuramos imitar o procedimento criando formas inusitadas em português, visivelmente errôneas.

cum uerba tonaret: "trovejando as palavras" é tradução mais próxima do literal; todavia, a oração admitiria uma tradução como "aos berros, em altos brados".

Quam doceret, coepit ante facere Deus: a conjunção antequam, aqui utilizada em tmese, pode reger subjuntivo, caso de doceret; já coepit se completa por verbo no infinitivo, a exemplo de facere. Este verso complementa o verbo Discite, do verso anterior. Normalmente, este verbo pediria, como complemento, uma oração infinitiva, ou seja, caberiam as alterações de "Deus" para "Deum" e "coepit" para "coepisse", por exemplo; mas em Gouveia ocorre, em nossa opinião, uma simples reprodução de discurso direto do monge.

retinet tempus: trata-se da idéia de "guardar", "respeitar", "preservar" ou "manter" o tempo métrico das palavras.

annis multo prudentia maior: / Caeca quibus uoluit non minor esse Dea: concordamos com a interpretação geral que Maria Luísa Meireles dos Santos dá a estes dois versos, no sentido de que se trata de um duplo elogio à inteligência (prudentia) e à longevidade dos irmãos, que foram, neste segundo aspecto, agraciados pela Fortuna (a Deusa cega, como bem notou a estudiosa). ${ }^{205}$ Entretanto, discordamos da análise sintática proposta, em dois pontos: primeiro, consideramos annis como ablativo com função de indicação temporal, e não ablativo de comparação; segundo, o pronome relativo quibus se referiria aos irmãos e estaria no dativo (de interesse), não sendo, a nosso ver, referência a annis, nem estando no ablativo (comparativo).

${ }^{204}$ Pois, em nosso entendimento, a vogal final de discite sofre elisão no encontro com ait. Até seria admissível prever um hiato nesse encontro vocálico, em virtude da pausa do discurso direto, que passa a indireto, mas, dentro da lógica do epigrama, acreditamos que se trata, efetivamente, de um erro proposital de prosódia.

${ }^{205}$ Cf. Santos, op. cit., p. 63. 
$\mathrm{Si}$, quae est uirtutum gratia blanda comes, / $\mathrm{Si}$, quae est nobilitas ab auis proauisque relicta, / Quae potuit meritis esse profecta tuis: não sem alguma hesitação, decidimos acolher boa parte da análise sintática de Meireles dos Santos ${ }^{206}$; nesse sentido, no verso 6, quae é pronome relativo, referente a gratia blanda; no 7 , quae (repetido em anáfora) se refere a nobilitas: em ambos os casos, o termo retomado está posicionado depois do pronome; no verso 8, Quae refere-se, novamente, a nobilitas, do verso anterior; em relação a outros elementos dos versos, no 6, uirtutum comes é predicativo do sujeito; no 7, est ... relicta é locução verbal, formando o perfeito do indicativo na voz passiva, enquanto ab auis proauisque indica o agente da voz passiva; no 8, profecta é particípio passado do verbo proficio, que tem, entre vários sentidos, o de "progredir, aumentar, engrandecer".

usus: uma tradução mais literal seria "valor", "serventia", "utilidade".

rursum, prorsum: procuramos transmitir, na tradução, um duplo sentido que parece existir por trás dessas duas palavras. Com efeito, tomadas individualmente, rursum significa "novamente, outra vez", enquanto prorsum significa "completamente, totalmente"; por outro lado, as duas palavras podiam ser utilizadas nessa ordem, em sequiência, formando uma expressão cristalizada, rursum prorsum, com o sentido de "para a frente e para trás, para cá e para lá". Como as duas interpretações parecem válidas e aplicáveis ao trecho em questão, a tradução foi adaptada a ambas.

IACOBVM ALENIVM: Segundo Luís de Matos, trata-se de Jacques de Reynaud, seigneur d'Alein, natural de Arles, onde chegou a exercer o cargo de primeiro cônsul, em 1549 , mesmo ano de sua morte. ${ }^{207}$

\footnotetext{
${ }^{206}$ Cf. Santos, op. cit., p. 65.

${ }^{207}$ Cf. Matos, op. cit., pp. 22-23.
} 
[48]

VVLTEIVM: Trata-se de Jean Visagier (dito Voulté), importante poeta neolatino do Humanismo francês, autor de várias obras, entre as quais os Inscriptionum Libri Duo.

Amazonidem: trata-se de uma alusão ao epigrama IV, 29, de Marcial, que usa esse termo no verso 8 , para se referir a uma obra excessivamente longa, mas sem valor literário. Trata-se de "Amazônide", uma amazonomaquia composta pelo epigramatista Marso, do século I d.C. Marcial o compara a Pérsio, mostrando que este autor é mais lembrado por um único livro do que Marso por toda a sua "Amazônia". O dístico de Marcial é o seguinte:

Saepius in libro numeratur Persius uno,

Quam levis in tota Marsus Amazonide.

[49]

Reddideris postquam: em nossa análise, reddideris está no futuro II ou futuro do pretérito; assim a correlação entre as duas orações fica estabelecida, de um lado, pela remissão de tum a postquam, e, de outro lado, pela consecutio temporum entre dabo (futuro simples) e reddideris, cuja ação, no futuro, é anterior à de dabo.

Saepius ardenti per laudes ire tuorum, / Perque tuas, titubat si, Catharina, manus: a construção sintática do trecho é complexa, sendo que o primeiro verso é claramente baseado no verso I, 15, dos Fasti, de Ovídio:

adnue conanti per laudes ire tuorum

Gouveia imita a sintaxe de Ovídio, isto é, o particípio presente utilizado, nos dois casos, rege o infinitivo "ire". No caso de ardeo, essa construção se encontra, por exemplo, em Virgílio (Eneida, IV, 281: "ardet abire") e no próprio Ovídio (Heróides, XVI, 79: "ardent sollicitare"). O particípio "ardenti" seria, assim, um dativo de interesse. Por isso, fica inteiramente descartada a solução ad hoc de Meireles dos Santos, que propôs a reinserção das palavras ingenium e uati, do verso final, que, segundo a estudiosa, estariam implícitas nesse 
período; uati formaria locução com ardenti, ao passo que ingenium seria o sujeito oculto do verbo titubo. ${ }^{208}$

GABRIELIS TARRAGAE: Conforme Luís de Matos, Gabriel de Tarrega, professor da Faculdade de Medicina, em Bordeaux, falecido em 1539. ${ }^{209}$

certe: em geral, Gouveia usa este advérbio no sentido de "pelo menos", "de todo modo", e pode-se experimentar um pouco desse sabor restritivo no primeiro verso do epigrama.

[56]

sit nulla secunda tibi: embora não haja dúvida em relação ao sentido geral do epigrama, em termos gramaticais tibi pode ser classificado de três maneiras diferentes: ou como dativo de posse, donde a tradução literal seria "não há nenhuma mulher segunda para ti", isto é, "tu não tens nenhuma mulher como segunda"; ou como dativo de atribuição (ou relação), indicando a posição que uma pessoa ocupa em relação a outra, donde uma possível tradução "não há nenhuma mulher em segundo lugar de ti", isto é, "no segundo lugar, comparada a ti"; ou, finalmente, como "dativo de aproximação", que daria origem à tradução que propomos, "não há nenhuma mulher em segundo lugar, perto de ti", até porque tal tradução recupera, em boa margem, os significados anteriores.

ueneres, numeros ac lumina: aqui, os termos são empregados como jargões técnicos, que se aplicam às qualidades literárias do discurso de Isócrates: ueneres são os encantos, as belezas poéticas, as seduções argumentativas; numeros refere-se ao ritmo, à sonoridade e melodia do texto; lumina são as construções brilhantes, as luzes do discurso, no uso da seleção e disposição das palavras, bem como dos recursos sintáticos.

\footnotetext{
${ }^{208}$ Cf. Santos, op. cit., pp. 75 e 122.

${ }^{209}$ Matos, op. cit., p. 24.
} 
minus assequi: apesar de minus, ao acompanhar a conjunção si em orações condicionais, seja usado, de forma mais restrita, apenas como advérbio de negação, significando simplesmente "não", decidimos aproveitar na tradução um sentido mais genérico de minus, como "não perfeitamente", "não totalmente", pois pareceu mais adequado ao contexto dos versos; em relação a assequi, esse verbo contém múltiplos sgnificados que poderiam se encaixar na tradução do verso; por exemplo, de um lado, "acompanhar, seguir de perto, alcançar"; de outro, "rivalizar, emular, igualar". Portanto, a escolha do vocábulo, por Gouveia, parece-nos excelente para indicar as dificuldades do tradutor, que não consegue "assequi" os brilhos e efeitos lingüísticos do texto original.

Quam nostro uitio: a tradução escolhida, "pela comparação com minhas limitações", pode induzir a uma análise gramatical equivocada, pelo que é conveniente esclarecer que o uso da conjunção quam invalida a explicação gramatical de uitio nostro como ablativo de comparação e complemento de melius; portanto, devemos considerar a expressão como ablativo de origem, isto é, "a partir de minhas limitações", ou como dativo, como agente, ligado a uideri, isto é, "transparecer ou ser vista por minhas limtações".

Enfim, também a escolha de "nostro uitio" parece ser primorosa, se considerarmos que um dos sentidos de uitio é o de incapacidade ou limitação que nos impede de atingir a perfeição, aqui muito bem aplicado por Gouveia, para dar conta das incapacidades ou limitações impostas à tarefa de tradução.

[58]

E Gallicis Mellini Sangelasii: trata-se da versão latina do seguinte poema, composto pelo poeta renascentista francês Mellin de Saint-Gelais, extraído da seção "Onzains", do capítulo “Sixains, Huitains, Douzains, etc.”, das obras completas:

\section{AU ROY FRANÇOIS}

Si la bonté se vouloit amender,

Et le bon sens plus advisé se faire,

Felicité mieux au sort commander,

Et mieux à tous la bonne grace plaire,

Perfection encores se parfaire,

Il leur faudroit de vous, Sire, obtenir 
Que leurs surnoms il vous pleust retenir,

Comme avez pris leur essence et effect,

En les souffrant à ce bien parvenir

Qu'après François on mette, à l'advenir :

Bon, sage, heureux, aggreable et parfaict.

Como se nota, Gouveia traduziu os onze versos do francês em quatro dísticos, isto é, oito versos.

[60]

Te nos unius aestimemus assis?: no verso final, Gouveia repete parte do terceiro verso do poema 5, de Catulo, do qual, aliás, toma o esquema métrico (hendecassílabo falécio). A escolha do termo "nugae" (adotado por Catulo logo em seu primeiro poema) também implica a associação deste epigrama com o gênero da poesia lírica de estilo alexandrino cultivada pelo poeta latino. Tal termo está realçado pela repetição em casos diferentes (poliptoto em ablativo e acusativo). Outra reiteração altamente enfática é a da anáfora "Te nos", que justamente se contrapõe, no verso final, à citação de Catulo, como elemento inovador e propriamente gouveiano.

\section{SEGUNDO LIVRO DE EPIGRAMAS}

Castra: Gouveia utiliza, neste poema, uma série de termos extraídos da linguagem bélica; procurou-se imitar este recurso, motivo pelo qual traduziu-se castra por "praça-deguerra”, ou seja, “acampamento militar", sentido próprio da palavra.

O jargão militar fica marcado e se impõe sobre todo o poema, ademais, pela posição inicial da palavra "castra", que abre o epigrama.

securo: embora o sentido primeiro do termo seja "tranqüilo, despreocupado", o contexto sugere o significado, também empregado nos autores clássicos, de "descuidado, negligente", isto é, o coração da jovem não se resguardava de um possível ataque do amor. Nesse sentido, parece-nos possível conjecturar uma tradução como "indefeso, desprotegido", por mais contraditório que isso pareça com conotações tradicionalmente associadas ao adjetivo "securus". Exatamente por isso, parece-nos não ser o caso de rejeitar a tradução 
sugerida por Santos, de "coração livre" ${ }^{210}$, pois acreditamos que tenha sido empregado justamente no sentido de "coração desocupado", à mercê de uma invasão pelo amor.

Quodque magis doleas: embora o verbo no subjuntivo indique um valor adverbial para esta oração, em vínculo lógico com a oração principal $^{211}$, houve dúvida em determinar o tipo de associação a preferir. Optou-se por uma tradução que privilegia um leve caráter causal da oração, mas não se deve descartar uma noção final, conforme sugere Santos, pela tradução "para que sofras mais" $" 212$.

affectas: preferiu-se a tradução "abatidas" porque pareceu se aproximar mais do campo semântico belicista do poema, a par de traduções como "subtraídas, enfraquecidas".

ab ore / Purpurei acciuit sanguinis auxilium: ainda na mesma linha de vocabulário bélico, pareceu-nos mais conveniente uma tradução como "convocou, recrutou", para o verbo "acciuit". O teor militar do vocabulário é expresso, ainda, no uso do termo auxilium, isto é, "tropa auxiliar, reforço"; algo pleonasticamente, frisamos a idéia pelo uso do termo militar "retaguarda". Quanto a ore, hesitou-se entre a tradução "face" e a possibilidade "boca vermelha", que talvez fosse preferível, dependendo da conotação que se quisesse dar ao trecho.

[5]

FRANCISCI VALLERIOLAE: trata-se do médico François Valeriola (ou Valleriola), antigo aluno da Faculdade de Medicina de Montpellier e amigo de Jacques de Reynaud. Segundo Luís de Matos, residia em Arles ${ }^{213}$; já Joaquim Veríssimo Serrão coloca-o a residir em Lyon ${ }^{214}$.

Perlege opus tantum: há uma ambigüidade acerca de tantum, pois o termo pode ser ou um advérbio, no sentido de "apenas, somente", como traduzimos, ou um adjetivo, neste caso acompanhando opus e significando "tão grande, tão importante"; portanto, caberia perfeitamente a tradução "Lê até o fim obra tão importante".

\footnotetext{
${ }^{210}$ Santos, op. cit., p. 83.

${ }^{211}$ Cf. Ernout, op. cit., pp. 334-341, especialmente $§ 335$ et sqq.

212 Santos, op. cit., p. 83.

${ }^{213}$ Cf. Matos, op. cit., p. 25.

${ }^{214}$ Cf. Serrão, op. cit., p. 81 .
} 
Noueris: acreditamos tratar-se do uso perfectivo do verbo nosco; assim, a partir do radical noui, o futuro do pretérito é utilizado na função e com o valor de futuro simples, “conhecerás" 215 . É de notar, como ensina Ernout, o emprego do futuro simples para indicar uma ordem suavizada, uma função que o futuro I do indicativo compartilha com o subjuntivo exortativo $^{216}$; tendo isso em conta, poderíamos propor uma tradução como "Conheças o autor...".

[6]

MONTANI IVRISPERITI: Jean Montagne, professor de Direito Civil, em Avignon, falecido pouco antes da publicação da obra, conforme Matos. ${ }^{217}$

[9]

inepta: pensou-se em soluções alternativas de tradução, ao lado de "mal feitos", como, por exemplo, "tolos", "fracos", "ruins". Cremos louvável a proposta formulada por Maria Luísa Meireles dos Santos, “insípidos”"218.

\section{[11]}

CIRETTI: Segundo Serrão, trata-se de Pierre de Ciret, conselheiro do Parlamento de Bordeaux desde 1519, falecido em 14 de junho de $1536 .{ }^{219}$

superesse putasset: quanto a putasset, vários sinônimos seriam adequados para traduzir o verbo, como "supor", “conjecturar", "pensar”, "julgar"; nossa preferência foi por "tivesse acreditado", substantivando, na tradução, o infinitivo verbal "superesse". Quanto a este verbo, usamos na tradução o sentido mais freqüente, de "sobreviver a, permanecer vivo", relacionando a idéia verbal à morte de Ciret e imaginando uma referência a um "defensor da lei” que vingasse a morte do advogado bordalês. Entretanto, talvez fosse mais acertado atribuir a superesse um sentido mais raro, mas previsto no OLD, que é o de "atuar como

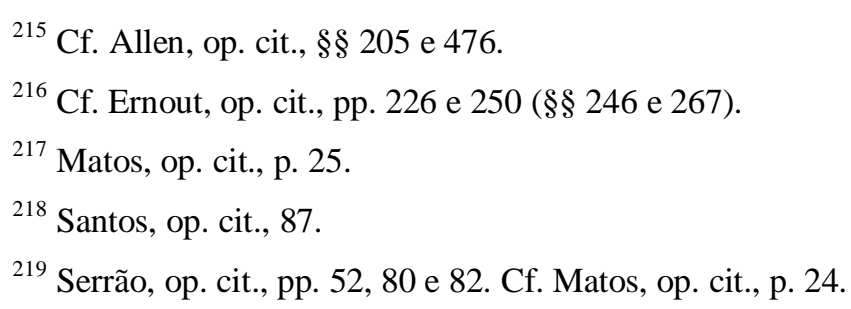


advogado". Assim, a tradução seria: "Se a Morte tivesse acreditado na atuação como advogado de um inimigo das injustiças semelhante a Ciret”.

Iniuriarum uindicem: numa tradução mais literal, "vingador das injustiças", “castigador das injustiças", aquele que pune os delitos; nossa tradução foi uma adaptação.

E GALLICIS MAROTTI: Este poema é a versão latina de outro epigrama de Clément Marot, constando do mesmo livro de epigramas do poeta francês de onde foi extraído o modelo do epigrama anterior, vertido por Gouveia (curiosamente, também o décimo-segundo epigrama, mas do livro I).

O poema francês original intitula-se "A Pierre Vuyard", é o epigrama de número 41 do Primeiro Livro de Epigramas de Marot. A mesma composição já havia sido vertida para o latim, dois anos antes, por Jean Visagier, que a publicara na sua própria obra de epigramas (Epigrammatum Libri Quattuor).

Os versos originais são os seguintes:

\section{A Pierre Vuyard}

Ce meschant Corps demande guerison,

Mon frere cher: et l'Esprit, au contraire,

Le veult laisser, comme une orde Prison:

L'ung tend au monde, et l'aultre à s'en distraire.

C'est grand' pitié que de les ouyr braire.

Ha (dit le Corps) fault il mourir ainsi?

Ha (dit l'Esprit) fault il languir icy?

Va (dit les Corps) mieulx que toy je soubhaitte:

Va (dit l'Esprit) tu faulx, et moy aussi:

Du Seigneur Dieu la voulunté soit faicte.

terrificum ... fremunt: considerando terrificum como adjetivo no gênero neutro em função adverbial, uma tradução mais literal seria "gritam de modo assustador". 
De numero uatum: a construção e o início deste poema lembram (numa provável alusão) um epigrama que Gouveia incluiu na sua edição das obras de Virgílio, como apêndice.

Note-se a semelhança:

\section{ALCINO I}

De numero uatum si quis seponat Homerum,

Proximus a primo tum Maro primus erit:

Et si post primum Maro seponatur Homerum,

Longe erit a primo, quisque secundus erit.

alma Venus: embora o adjetivo almus provenha do verbo alo (alimentar), tendo o sentido de "nutridor, alimentante", o OLD recomenda a tradução por "gentil, graciosa, propícia", quando usado como epíteto de deusas.

Hic Iuno, ante alias, medio interfata dolore est, / Singultu tremulos excutiente sonos: a tradução, nestes versos, afastou-se um pouco da literalidade, e admite certas alternativas. Veja-se, por exemplo, que "interfata est", pretérito de interfor, tem o sentido de "falar interrompendo outro, interromper"; em razão disso, bem caberia a tradução "antes das outras" para ante alias. "Singultu excutiente", por sua vez, é um ablativo relacionado a tremulos, exprimindo de certo modo a causa do tremor da voz; como singultus tanto pode ser "suspiro" ou "soluço", ao passo que excutio significa "arrancar, sacudir", abre-se um leque de possibilidades de tradução, como "suspiro fundo", ou "soluços sacudidos", ou melhor, "que sacodem". Enfim, optou-se por "entre soluços convulsos".

[18]

Nugarum: convém recordar que Nugae é o título da obra do poeta neolatino francês Nicolas de Bourbon. 
Auctus: quando o termo vem associado a casamento ou nascimento de filhos, como neste caso (filiabus duabus), o OLD ${ }^{220}$ indica a tradução "abençoado", "feito feliz", donde deduzimos "agraciado"; a pertinente tradução de Santos foi "enriquecido",221.

Pythagorae: Pitágoras, filósofo grego do século VI a.C., propôs e difundiu a teoria da transmigração das almas.

circum: trata-se, aqui, não da preposição, que rege acusativo, inexistente no verso, pois brachia complementa dans; quanto a collo, que seria a única opção condizente com o contexto, está no dativo. Portanto, devemos considerar circum um advérbio, com o sentido de "em torno, em redor", ou ainda "por todos os lados". Para distinguir nitidamente o uso de circum como advérbio e não preposição, propusemos a tradução "rodeando-a".

reddito: a tradução deste verbo como "entregar" não anula o sentido aqui subjacente de “devolver, restituir".

Liquit: também aqui o contexto admite uma tradução alternativa, dentre os vários sentidos conhecidos do verbo, que seria "Confiou".

[25]

dilecta pectora: preferiu-se manter na tradução o termo "corações", embora pudessem existir alternativas que explicitassem a figura, como "vozes" ou "mentes" amados por Febo. Nessa linha é que Meireles dos Santos utilizou a tradução "almas".

scommata: trata-se da transliteração do substantivo grego skw mma, skw mmatoj, que significa, justamente, "sarcasmo, escárnio, gracejo, zombaria", derivado do verbo skw/ptw, que significa "zombar, escarnecer". Em outros momentos da obra, Gouveia preferiu usar palavras gregas mantendo a grafia e o alfabeto de origem, mas, neste exemplo, optou pela transliteração.

[27]

\footnotetext{
${ }^{220}$ OLD, p. 213, sub uoce augeo, 6c.

${ }^{221}$ Santos, op. cit., p. 95.
} 
ANTONIVM ARLERIVM: Conforme Matos, é Antoine Arlier, nomeado "lieutenant du sénechal" de Arles, a partir de $1535 .^{222}$

grauitas: pelo contexto, sobretudo a partir do verso 4, a palavra aqui está empregada num sentido privilegiado de "severidade, austeridade, rigor", especialmente nos julgamentos.

caelitus: advérbio de uso raríssimo no latim clássico, mas registrado no $\mathrm{OLD}^{223}$, com o sentido de "do céu" (from heaven).

Quae faciunt: segundo nossa análise, o pronome relativo quae tem a função de sujeito do verbo faciunt e retoma os substantivos femininos grauitas, prudentia e cognitio. Por esse motivo, acreditamos que a noção do verbo faciunt no verso não é a de "fazer", mas se aproxima de "dispor”, “determinar”, “fundamentar", “indicar”, “prescrever”.

[28]

ingenio, lepore, forma: esses três substantivos no ablativo, assim como aqueles empregados nos versos seguintes, na mesma relação com o verbo uinci, tem a função de ablativo de relação (ablative of respect), de acordo com o OLD. ${ }^{224}$ Da mesma forma, Allen trata esse uso do ablativo de uma maneira independente do ablativo instrumental, denominando-o "ablativo de especificação", o que nos parece inteiramente válido. Ernout, entretanto, usa a nomenclatura "ablativo de ponto de vista" e o considera um tipo enfraquecido de ablativo instrumental. Embora a classificação de Ernout tenha como motivação a evolução histórica da língua latina, a análise de Allen nos parece mais adequada e mais precisa no reconhecimento da função específica do ablativo, notadamente na situação vislumbrada nos versos em questão, a respeito do verbo uinco.

[30]

IOANNIS ALBERTI: Trata-se do "prieur" Jean Albert, de La Réole, segundo Luís de Matos. $^{225}$

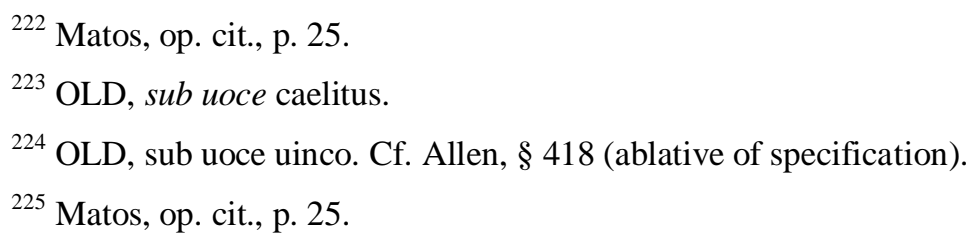


Ast Amor auriculam subito miseratus amantem: a tradução apresentada é uma adaptação, uma vez que, sintaticamente, miseratus rege genitivo; portanto, gramaticalmente, deve-se entender que amantem é particípio verbal qualificando auriculam. Uma tradução mais próxima da construção original seria: "Mas o Amor, subitamente compadecido, puxou a orelha deste homem apaixonado".

obtutum: embora a tradução "olhar contemplativo" possa ser ambígua, a idéia preponderante é a de um "olhar pensativo", até mesmo um "olhar perdido". Nossa preferência foi manter uma certa ambigüidade em suspenso, para ser resolvida pelo contexto, sobretudo com o verso final.

BASSA: Nome de mulher, usado, entre os clássicos, apenas por Marcial, em cuja obra se registra nove vezes.

sacrificum: a hipótese levantada por Maria Luísa Meireles dos Santos é a de que se trata de um genitivo plural, seja referente a um suposto substantivo sacrifex (que não se encontra em nenhum autor antigo), seja referente a uma forma irregular de genitivo plural em "um" (da mesma forma, sem comprovação). Apesar de razoável, preferimos trabalhar com outra hipótese: a de que se trata do acusativo singular de sacrificus; neste caso, estaríamos diante de um duplo acusativo, como complemento do verbo emo, sendo um (o principal) de pessoa, sacrificum, e um (secundário) de coisa, preces; cabe observar, todavia, que essa construção, embora comum com outros verbos, entre os quais precor e posco (com o uso recorrente do complemento preces), não aparece, entre os clássicos, com o verbo emo.

rapido: este adjetivo, aplicado a ignis, significa "abrasador, causticante"; trata-se aqui, decerto, de uma alusão ao inferno onde estaria a alma do promíscuo marido.

preculis: também não há registro desse vocábulo entre os autores antigos.

exudauerit: o verbo está no perfeito do subjuntivo, mas, em função do contexto, preferimos adaptar o tempo verbal, na tradução, passando-o para o presente.

Gallae ... luis: literalmente, "peste ou febre francesa", ou, em outras palavras, "malgálico", um dos inúmeros nomes com que é conhecida a sífilis, em função do título do livro quinhentista de Fracastoro, Syphilis siue morbus gallicus, a partir do qual se batizou a doença. 
SVSANNAEVM: Nome latinizado do poeta neolatino francês Hubert Sussannée (ou Sussanneau), contemporâneo de Gouveia.

Ska/zon: Gouveia manteve em caracteres gregos esse termo da poesia grega, o escazonte, metro também conhecido por coliambo. O termo Ska/zon, inicialmente um adjetivo, significa "manco", derivado do verbo ska/zw ("coxear, mancar, claudicar"). A mesma idéia está presente em coliambo, que significa, literalmente, “iambo manco". O verso recebe esse nome por ser uma variante do trímetro jâmbico, em que há uma quebra na sequiência dos pés métricos, sendo o último invertido, passando de iambo a troqueu, gerando a imagem de um "iambo manco", isto é, de pé invertido.

claudo: ao chamar o amigo de poeta "manco", é evidente o trocadilho de Gouveia com o termo recorrente do epigrama, o escazonte, isto é, o "manco" (ou, restritivamente, o "verso manco").

PRO CTESIPHONTE: discurso vitorioso proferido por Demóstenes, em Atenas, em 330 a.C., em defesa de Ctesifonte, diante da acusação de Ésquines, que acabou exilado.

gelido ... amne: o adjetivo gelidus, muito apropriadamente utilizado por Gouveia, significa "frio, apagado, sem vida", e se aplica especialmente em situações em que havia um fogo ou calor que se extinguiu, exatamente como no verso em questão. Qualificando o substantivo amnis ("torrente, enxurrada"), dá quase a idéia de uma fluência mecânica a substituir a força discursiva do original.

Caecuba uina: vinhos de excelente qualidade, produzidos no vale de Cécubo, no Lácio; proverbiais pelo valor, indicam, na literatura clássica, o vinho superior.

meliore Camena / Dignior: Camena foi associada, entre os romanos, com as Musas gregas, passando a ser um equivalente de Musa, que foi, aliás, a tradução apresentada por Santos $^{226}$. Por metonímia, Camena também significa "poesia", outra possibilidade de tradução. Aqui, meliore Camena, no ablativo, é o complemento de dignior, ou seja, do adjetivo dignus no grau comparativo; a nosso ver, pode-se considerar tanto como ablativo de comparação, ou seja, "mais digna do que a melhor Camena/poesia", quanto ablativo de

${ }^{226}$ Santos, op. cit., p. 107. 
acompanhamento (segundo Ernout ${ }^{227}$ ) ou especificação (segundo Allen ${ }^{228}$ ), complemento normal de dignus, ou seja, "muito digna da melhor Camena/poesia". De todo modo, a idéia do trecho parece ser compreensível: Catherine, digna de figurar nas páginas dos melhores poetas, digna até de algo acima disso (o comparativo dignior a indicar que ela está acima mesmo da melhor poesia, sendo uma condescendência a sua presença até mesmo nos melhores poemas), Catherine, como dizíamos, admite figurar na obra de Gouveia.

[40]

curua gnarum testudine, Diuum / Restinguere ardenteis minas: o sentido próprio de testudo é "tartaruga" ou, por metonímia "carapaça de tartaruga"; aqui, entretanto, é claro o sentido conotativo de "lira", classificando a obra lírica de Salmon Macrin, por oposição à obra satírica ou invectiva (isto é, jâmbica) de Étienne Dolet, e a epigramática de Bourbon, publicada sob o título Nugae.

Já o adjetivo gnarus, "sábio, conhecedor", pode ter como complemento uma oração infinitiva, situação que se verifica neste poema. Restinguere significa "arrefecer, neutralizar, pôr fim". Em função de se traduzir ardenteis por "ardentes", preferiu-se, para o verbo restinguere, a tradução "aplacar", equivalente de "abrandar". Outra possível tradução de ardenteis seria "violentas". Neste caso, ficaria interessante a tradução "apaziguar" para restinguere, reforçando a antítese "restinguere $\mathrm{X}$ ardenteis" do original.

Vultei, Brixi, Marthane, Ducheri: trata-se da enumeração de importantes poetas da França renascentista, que se somam à citação anterior de Dolet, Macrin e Bourbon, formando um rol dos poetas neolatinos mais importantes e celebrados daquele país na década de 1530 . Vulteius é o nome latino de Jean Visagier, também conhecido por Voulté; Brixius é Germain Brice (ou Brie), Marthanus é Charles de Sainte-Marthe; Ducherius, finalmente, é Gilbert Ducher.

Poeseos: genitivo singular de poesia, por imitação da desinência grega de genitivo singular de palavras da terceira declinação de sufixo nominativo "-sis".

\footnotetext{
${ }^{227}$ Ernout, op. cit., p. 103, § 125 .

${ }^{228}$ Allen, op. cit., p. 262, § 418.
} 


\section{NOTAS E COMENTÁRIOS}

\section{A EPIGRAMMATA (I540)}

\section{Poema introdutório LIBELLVS LECTORI}

9 Nunc mihi lucis amor tardas crescebat in horas: este verso se modela sobre o verso 73 da décima écloga de Virgílio:

Gallo, cuius amor tantum mihi crescit in horas

12 Quos studium multos euigilarat idem: verso evidentemente modelado sobre o seguinte verso ovidiano (Tristia, I, 1, 108):

quos studium cunctos evigilavit idem.

20 Palluit os: flauae diriguere comae: alusão a um verso das Heróides (V, 122):

at mihi flauentes diriguere comae.

\section{EPIGRAMAS}

[1]

D. FRANCISCO VALESIO REGI FRANCORVM: como fizeram vários outros poetas franceses da época, Gouveia abre o livro de epigramas com um poema dedicado ao rei francês, D. Francisco I (François de Valois), que reinou sobre a França entre 1515 e 1547 e passou à história como protetor das Letras e da Renascença. 
RODORICO FERNANDO, IOANNIS LVSITANIAE REGIS LEGATO: segundo a identificação feita por Luís de Matos $^{229}$, trata-se de Rui Fernandes de Almada, embaixador português na França, entre 1534 e 1540.

astra: embora tenhamos preferido uma tradução literal, cumpre lembrar que o termo latino conota a idéia de céu como espaço divino, sendo que astra admite, até mesmo, a tradução de "deuses" ou "seres divinos", conforme indica o OLD.

[7]

GVIDONIS RANGONII: segundo Luís de $\operatorname{Matos}^{230}$, trata-se do capitão italiano Guido Rangone, morador de Lyon e naturalizado francês em 1538.

D. LIENORAE REGINAE FRANCORVM MAXIMAE: epigrama dedicado a D. Leonor da Áustria (ou Leonor de Habsburgo), viúva do rei português D. Manuel e casada, desde 1530, com o rei francês D. Francisco I, em função dos acordos de paz entre os franceses e os alemães. Rainha da França, D. Leonor era irmã do imperador Carlos V (Habsburgo), cujos domínios se estendiam sobre a Espanha, os Países Baixos, o território alemão e boa parte da Europa Central.

ALDI MANVTII ROMANI: O humanista Aldo Manuzio foi um dos mais importantes editores do Renascimento europeu. Nascido em Sermoneta (ou Bassiano), estudou em Roma e Ferrara. Fixou-se em Veneza, por volta de 1490, instalando nessa cidade sua famosa tipografia. É considerado o pai das artes tipográficas e do trabalho editorial em sentido moderno. Faleceu em 1515.

D. MARGARITAE VALESIAE REGINAE NAVARRORVM: poema dedicado a D. Margarida de Valois, irmã mais velha de D. Francisco I, rei da França, e rainha de Navarra por casamento realizado em 1527 com o rei D. Henrique II, de Navarra. Foi conhecida

\footnotetext{
${ }^{229}$ Matos, op. cit., p. 30.

${ }^{230}$ Cf. Matos, op. cit., p. 26.
} 
protetora dos artistas e escritores, tendo recebido educação humanística e escrito algumas obras literárias. Também é conhecida por Margarida de Navarra (nome com que assinava suas obras) ou Margarida de Angoulême, para a diferenciar de várias rainhas francesas que portaram o mesmo nome. Viveu de 1492 a 1549.

altera partus sors magni: do casamento entre Carlos de Valois e Luísa da Sabóia nasceram apenas dois filhos (Margarida e Francisco), donde se compreende o elogio feito por Gouveia e a sua escolha, muito apropriada, do termo "altera".

Quanto à palavra partus, seu sentido primeiro é o de ato de parir ou gerar filhos, dar à luz, mas não é difícil perceber o mecanismo de metonímia entre a ação de parir e o fruto da ação, donde o sentido derivado de "descendência, progênie"; tal fenômeno se observa, aliás, na palavra "geração", que poderia ter sido utilizada, por sinal, nesta passagem.

Em relação a tal utilização metonímica da palavra partus, cabe notar que Gouveia repete aqui o mesmo emprego que adotara, por duas vezes, nas cartas, como se pode ver no cotejo com os versos a seguir:

Sorsque tui partus ultima, Mater, ego (Ep. I, 20);

Vltima sors partus illius ipse fui (Ep. IV, 73).

ZOILO: o nome de Zoilo, a partir da figura do filósofo cínico que criticou, no século IV a.C., a obra de Homero, tornou-se proverbial do crítico implacável e insensato. Muitos poetas neolatinos franceses do círculo de Gouveia, como Salel, Dolet ou Bourbon, fizeram grande número de poemas dedicados a "Zoilo", satirizando a fundo a personagem do crítico irascível. Gouveia, neste epigrama, parece ser mais condescendente que seus contemporâneos.

ANTONII GOVEANI AVI OPTIMI ATQVE MERITISSIMI: Trata-se de Antão de Gouveia, avô materno do poeta, cavaleiro da Ordem de Cristo e combatente em Arzila e Toro, batalhas travadas em 1471 e 1476, respectivamente, sob o comando de D. Afonso V. 
Parece-nos que este epigrama é construído sobre um jogo de palavras em latim. Com efeito, o verbo "luo" não tinha uma forma para o particípio passado, mas, em compensação, registrava a forma "luiturus" para o particípio futuro. Por outro lado, o verbo "eluo" tinha particípio passado regular, "elutus"; assim, o particípio futuro seria "eluturus", e não “eluiturus”, forma que seria, segundo Gouveia, utilizada pelos espanhóis (mais precisamente, os habitantes da Península Ibérica), cuja construção foi feita por analogia com a forma "luiturus". No poema, Gouveia brinca com a crítica que alguém teria formulado ao "erro" dos espanhóis, e faz uma conclusão remetendo ao sentido do verbo "luo", que significa, justamente, entre outros sentidos, "dispensar de uma obrigação".

[39]

IOANNI ROMANO CREMONENSI CASALINO MAIORITANO: poema dedicado ao mesmo Giovanni Romano a quem se endereça a carta inicial da obra. Pelo conteúdo do epigrama, é possível deduzir que se tratasse de um médico italiano, originário da cidade de Casalmaggiore, na Cremona.

[48]

sciomace/eij: o verbo grego empregado no original por Gouveia tem o sentido inicial de lutar contra uma sombra ou um fantasma, e, a partir daí, adquire o sentido conotativo de empreender uma luta vã, quimérica, quixotesca.

Evidentemente, Gouveia aproveita o duplo sentido do verbo para estruturar seu epigrama, incorporando a dupla idéia de que, para o destinatário do poema, emular com os autores do passado é competir com “fantasmas” e, também, lançar-se numa competição desigual e inútil.

[49]

EQUITI HIEROSOLYMITANO: supomos tratar-se de um cavaleiro da Ordem do Templo de Jerusalém, isto é, um cavaleiro templário, cuja instituição, em Portugal, foi substituída pela Ordem de Cristo.

defuncte periclis: essa expressão se encontra, por exemplo, em Cícero, com o sentido de "livre dos perigos" (Pro Roscio Amerino, VIII, 21). Mas nos parece que o emprego da expressão por Gouveia, neste trecho, está associada ao sentido primeiro do verbo, ou seja, 
aquele que está livre dos perigos porque, cumprindo sua obrigação, os enfrentou e venceu; daí a tradução proposta.

[72]

CLYTAEMNESTRA / ORESTI / E Graecis: trata-se de uma versão para o latim do epigrama IX, 126, do volume de epigramas sepulcrais (epigrammata sepulcralia) da Antologia Palatina.

cum Fratre Sorores: Gouveia trata Apolo como irmão das musas, aproveitando-se do fato de que ele costumava ser representado juntamente com elas, donde viria seu epíteto "Musagetes", isto é, condutor das musas.

Vt coelo se Rufinus lapsum esse putarit, / Rufino ignotus fecit uterque parens: Uma tradução literal leva à inversão na ordem dos versos do dístico, ficando do seguinte modo: "Os pais, por serem desconhecidos de Rufino, / fizeram com que Rufino pensasse que caiu do céu".

[88]

CAROLO MARTHANO: Charles de Sainte-Marthe foi um importante humanista francês. Formou-se em direito em Poitiers e seguiu a carreira docente, até passar a enfrentar problemas devido às polêmicas religiosas na França. Esteve preso por dez anos em Grenoble, até ser solto e transferir-se para Lyon, onde deu aulas de línguas clássicas e recebeu a proteção de Margarida de Navarra. Faleceu por volta de 1562. De seus numerosos escritos quase nada resta.

[95]

HECVBA / E Graecis: trata-se de uma versão para o latim do epigrama IX, 117, do volume de epigramas sepulcrais (epigrammata sepulcralia) da Antologia Palatina.

[98] 
Si qua suo fuerint, ut erunt, indigna parente, / Edita temporibus scito fuisse meis (...) Sola mihi requies, et lenti temporis usus, / Non est ingenio fama petita meo: estes quatro versos, que compõem o dístico inicial e o final do poema, são modelados sobre o primeiro poema do livro IV dos Tristia, como se vê:

Siqua meis fuerint, ut erunt, vitiosa libellis, excusata suo tempore, lector, habe.

exul eram, requiesque mihi, non fama petita est,

Este epigrama, portanto, busca um intencional paralelismo com a elegia ovidiana, a fim de criar uma identidade entre os dois poetas, Gouveia e Ovídio. 


\title{
NOTAS E COMENTÁRIOS
}

\section{A EPISTOLAE QVATTVOR (I540)}

\author{
Carta dedicatória a Giovanni Romano
}

IOANNI ROMANO CREMONENSI CASALINO MAIORITANO: Não foi possível identificar com exatidão esta personagem. Apenas foi possível prever que se trata de um médico italiano, natural da comuna de Casalmaggiore, no extremo sul da província de Cremona, na Lombardia, próxima da Emília-Romanha, provavelmente atuante em Lyon. É possível que se trate de um antepassado do abade Giovanni Romani, historiador do século XVIII, natural da mesma localidade. Propusemos, a título meramente hipotético, o nome italiano Giovanni Romano (quiçá Romani), mas, considerando a sua circulação em território francês, poderíamos também supor uma grafia afrancesada como Jean Romagne.

factum nisi tibi a me abunde satis putas: este trecho lembra, sem dúvida, as palavras semelhantes que Gouveia dirigiu a Jacques de Beaune, no oitavo parágrafo da carta introdutória ao livro: "factum abs te abunde satis putabo". Comparem-se estas frases com a correspondente, empregada na edição do ano anterior, 1539: "Mihi profecto factum abunde erit satis".

Carta dedicatória a Catherine de Beauffremont

ineptire: segundo o OLD, o verbo significa "agir como bobo, bancar o tolo"; evidentemente, trata-se de agir de forma insensata em virtude da paixão amorosa, isto é, cometer loucuras de amor; o uso do verbo é raríssimo entre os clássicos, razão pela qual não deixa de repercutir nesta carta de Gouveia o verso inicial do oitavo poema de Catulo, "Miser Catulle, desinas ineptire".

Primeira carta 
8 genis: como muito bem observou Zeeb, genis não é ablativo locativo, indicando o lugar por onde o choro escorre, mas ablativo de origem, indicando a partir de onde as lágrimas escorrem; torna-se mais coerente, por isso, o uso do adjetivo grauidis, aplicado a genis, no sentido de inchado: de resto, grauidis como inchado e genis como olhos encontra suporte nos autores clássicos, como ilustra o próprio OLD.

9-10 Tandem ubi per lacrimas licuit, sed flebilis orsa est, / Singultu tremulos excutiente sonos: em relação à interpretação propriamente dita do verso 9, Zeeb considera que o sujeito oculto do verbo orsa est é littera, propondo que o adjetivo flebilis se refere à carta, de teor lamentoso. ${ }^{231}$ Sem negar a coerência da posição de Zeeb, e a perfeita adequação do comentário ao caráter elegíaco e lamurioso da composição, parece-nos admissível supor que o sujeito seja Musa, isto é, a mesma deusa que impediu a composição poética, por abandonar o autor a meio caminho, agora se põe a falar, de modo lúgubre, assoprando, ao poeta, uma elegia. Esta leitura, considerando a musa como tropo, nos parece mais apropriada ao caráter poético do texto, embora seja evidente que tal musa elegíaca está apenas ocupando o lugar de elementos concretos, como a carta e o autor do texto. Além do mais, quando Gouveia usou o mesmo verso, no ano anterior, quem falava, naquele contexto, era uma deusa (Juno), e é muito provável que isso tenho influenciado o poeta, ao imaginar a mesma cena, agora com a Musa a falar.

15-16 Venimus huc, credo, fatis auctoribus ambo / Et patrium maestus liquit uterque solum: como bem observou João Angelo Oliva Neto, durante o exame de qualificação, a construção de Gouveia dá ao Destino (os Fados) a personalidade de autor dos acontecimentos, lembrando expressões correntes no português, como "escrito pelo destino" ou "isso já estava escrito"; nesse sentido, poderíamos traduzir usando a expressão "por decreto do destino", muito apropriada se pensarmos que auctor não é apenas "escritor", mas "autoridade", “detentor do poder". Em relação a ambo, cabe notar que a palavra indica união e reciprocidade: é como se, por decisão do destino, os dois tenham ido juntos, ao mesmo tempo, para a cidade de Lyon. O uso de ambo contrasta com o de uterque, no verso seguinte: de fato, o ponto de partida de ambos é diferente: Gouveia abandonou sua pátria, Portugal, ao passo que Catherine teria saído de Avignon para ir a Lyon, numa mudança apenas regional. Assim,

${ }^{231}$ Zeeb, The Latin Letters of Antonio de Gouvea, pp. 42-43. 
o contraste entre ambo e uterque acaba por salientar a idéia de que, tendo partido separados (uterque), acabaram por se unir (ambo), por força do destino (fatis auctoribus) em Lyon (huc).

17 Beia mihi patria est: imitação do hemistíquio inicial de um verso dos Tristia de Ovídio (IV, 10, 3): Sulmo mihi patria est.

fuerat Pax Iulia priscis: a cidade de Beja, no Alentejo, tinha, entre os romanos, o nome de Pax Iulia. Segundo o historiador António Marques de Faria ${ }^{232}$, essa colônia romana teria sido fundada entre 31 e 27 a.C., e seu nome seria uma homenagem de Augusto a Júlio César, num esforço de propaganda que procurava, dessa forma, enaltecer o antigo dictator, ao qual Otaviano se ligava pela adoção e pela sucessão, logo após a batalha de Actium. Embora sua explicação esteja muito bem fundada e encontre paralelo em diversas outras cidades que receberam um cognome Iulia, cabe admitir que há certa polêmica sobre a questão, e alguns estudiosos preferem atribuir o batismo ao próprio Júlio César, que naquele sítio teria obtido uma decisiva vitória militar sobre os lusitanos.

23 populosa Lutetia: Gouveia faz uma combinação interessante: usa um nome erudito e de sabor clássico para designar a cidade de Paris (Lutetia), mas faz acompanhar esse nome de um adjetivo (populosa) que não existiu no latim clássico.

24 studiis bonis: segundo Zeeb, a expressão não deve ser entendida como referência aos estudos liberais ou humanísticos, mas meramente como "estudos úteis". 233

$25 \mathrm{Me}$ tamen a primis bello sacrauerat annis, / Vt successorem laudis haberet auus:

Declara Gouveia, na Epistola Prima, que se dedicou às armas, antes de seguir a carreira acadêmica, imitando o exemplo do avô. Não se sabe ao certo a que se refere o poeta, podendo, inclusive, essa referência ao abandono das armas em prol do estudo não passar de um lugar comum. É de pensar, inclusive, se Gouveia, ao falar de si, nessa carta de teor

${ }^{232}$ Faria, "Pax Iulia, Felicitas iulia, Liberalitas Iulia", in Revista Portuguesa de Arqueologia, volume 4, número 2.2001.

${ }^{233}$ Zeeb, op. cit., p. 45. 
autobiográfico, não estaria projetando em sua pessoa uma espécie de opção comum aos irmãos, que foi a renúncia da vida militar, trocada pela carreira acadêmica. Por outro lado, conforme se discutirá mais adiante, Luís de Matos não acredita nessa hipótese, entre outros motivos, porque Gouveia declara, na dedicatória da compilação Terentii Comoediae Sex, que se dedicou aos estudos desde jovem.

38 rogis: Zeeb avança uma interpretação interessante: a de que o uso do vocábulo rogis, que significa, literalmente, o fogo da pira funerária, já traria subliminarmente a idéia de perdição que o eu-poético atribui à sua visão da mulher amada.

39 aequor: a palavra, literalmente "superfície plana", não foi incorporada na tradução: o verso, ao pé da letra, seria "Ai, quanta superfície de terra, quanta superfície de mar arei”, sendo que "aequor", em apó koinou, rege os genitivos "terrae" e "maris".

40 cassibus: ablativo plural de cassis, que significa "armadilha, cilada, emboscada, ardil”, e foi utilizada na poesia erótica latina, para se referir às armadilhas do amor.

43 Nobile simplicitas dederat tibi candida nomen: simplicitas significa "candura, franqueza, ausência de malícia, pureza de alma, ingenuidade"; o adjetivo candida ("puro, límpido, branco, sem manchas") reforça quase pleonasticamente a expressão. Há aqui uma brincadeira verbal com o nome de Catharina, que deriva do adjetivo grego kaqaro/j e quer dizer, justamente, "puro, imaculado". Todo o verso, portanto, se reveste de duplo sentido: de um lado, a palavra catharós (puro) deu origem ao seu nomen (isto é, o nome próprio) Catharina (cujo significado etimológico é “a pura”, "a pureza”); de outro, a pureza impecável e irrepreensível do comportamento de Catherine deu origem ao seu nomen (isto é, bom nome, boa fama, reputação); note-se que essa característica da personalidade de Catherine vai ser evocada novamente na segunda carta (verso 5).

50 Aonios demens deseruique lacus: demens, aqui, indica o estado da pessoa cega de amor, enlouquecida, desvairada pela paixão. Aônio é um adjetivo usado para se referir à Beócia, ou seja, é uma referência poética às Musas (Aoniae sorores, como as chama Ovídio, em Tristia, IV, 10, 39). Em seu transe amoroso, Gouveia teria deixado de escrever, deixando de beber da fonte das musas (Aonios lacus). 
56 Materiamque tibi saepe dedere ioci: o sujeito de dedere é ioci (e não ignes, do verso anterior); materia, em latim, significa "madeira, lenha, alimento da chama", ou ainda, conotativamente, “incentivo”. Quanto ao substantivo ioci, parece razoável associá-lo a gracejos, ou, mais especificamente, aos gracejos dos poemas epigramáticos compostos por Gouveia, muitos dos quais foram publicados no ano anterior, celebrando seu amor por Catherine. De fato, na obra de 1539, Gouveia usa o termo cinco vezes, quatro das quais com esse sentido específico de gracejos poéticos. Nos epigramas que, no livro de1540, antecedem as cartas, o termo aparece duas vezes, nesse mesmo sentido de gracejo característico do epigrama. A partir daí, o sentido do verso se aclara: os epigramas amorosos de Gouveia, repletos de declarações apaixonadas, alimentaram o "fogo" (ignes, verso 55) de Catherine.

Portanto, discordamos da interpretação de Katherine Zeeb ${ }^{234}$, que afirma que fazer gracejos foi a maneira que Catherine encontrou para revelar disfarçadamente seu amor, diante das regras sociais e de sua reserva e modéstia. Nessa linha de raciocínio, Zeeb entendeu que materiam teria o sentido de "ocasião, oportunidade"; sua tradução do verso foi "jesting has often given you this opportunity", ou seja, por meio de brincadeiras ela confessou seus sentimentos. Neste caso, os gracejos partiram dela.

Nossa divergência em relação a essa interpretação se baseia não apenas na associação que Gouveia estabeleceu, anteriormente, entre a palavra ioci e a atividade poética, acima comentada, mas também porque identificamos duas incoerências na análise de Zeeb. Em primeiro lugar, uma questão de coerência textual: se Catherine já revelou, ainda que obliquamente, por meio de brincadeiras, seu amor por Gouveia, porque ele precisa pedir que ela confesse ou admita o que ele mesmo já teria percebido? A menos que, no verso anterior, se trate do pedido de uma declaração séria, um “juramento de amor”, não há necessidade de arrancar uma confirmação de um sentimento que ela já teria deixado entrever por meio de brincadeiras. Em segundo lugar, parece haver uma incoerência contextual: se Catherine era um poço de reserva e modéstia, como demonstra Zeeb, e se as convenções sociais da época impediam que uma mulher se declarasse a um homem, não deixa de ser estranho que ela fizesse brincadeiras a esse respeito, e aproveitasse alguma oportunidade para revelar seus sentimentos num tom de brincadeira, como deduz a estudiosa norte-americana.

\footnotetext{
${ }^{234}$ Zeeb, op. cit., pp. 52-3.
} 
58 Et mihi pro lingua lucidus ignis erat: a tradução, literal, não acompanhou o duplo sentido do termo ignis, que, no nível conotativo, indicava o brilho dos olhos; ou seja, seu amor era expresso não por meio de palavras, mas pelo brilho do olhar. Zeeb preferiu uma tradução interpretativa, em paráfrase: "how often the bright fire in my eyes serve for language".

65 Quod si quem nostri forsan iuuere labores: Zeeb interpretou o verbo іииеre como "ajudaram", explicando que seria uma referência de Gouveia à sua atividade como professor de Direito ou advogado. No entanto, não há nenhuma informação acerca da relação do poeta com a área do Direito, nessa altura de sua vida, como bem demonstrou Joaquim Veríssimo Serrão. Só muitos anos mais tarde é que Gouveia irá dedicar-se à atividade jurídica. Portanto, mais de acordo com sua atividade como humanista, naquele momento, entendemos nostri labores como referência a suas obras poéticas, ou, eventualmente, de comentário e tradução de textos clássicos. Aliás, é nesse sentido que o poeta usa o substantivo labor, em seus livros. Por esse motivo, pareceu-nos aconselhável entender iuuere no sentido de "agradar".

67 Quid uerbis opus est: essa interrogação não é incomum, aparecendo em Plauto e Terêncio. Também reproduz o verso das Metamorfoses em que Ajax desafia Ulisses pela posse das armas de Aquiles (Metamorfoses, XIII, 120-122):

\section{'Denique quid verbis opus est? spectemur agendo! \\ arma viri fortis medios mittantur in hostes \\ inde iubete peti et referentem ornate relatis.'}

Essa passagem chegou a ser traduzida por “De que valem as palavras?”, por David Jardim Júnior ${ }^{235}$. Com efeito, a intenção da pergunta, que se aplica inclusive à passagem de Gouveia, é a de questionar o uso das palavras, por oposição aos fatos concretos, permitindo traduções como: "Por que é preciso ficar nas palavras?", "Que falta fazem as palavras?” ou até uma exclamativa "Mas chega de palavras!".

${ }^{235}$ In Ovídio, As Metamorfoses, p. 235 (tradução de David Jardim Júnior). 
70-71: quam, posses iure negare, uelim. / Ac uellem, ut cuperes id tu, Catharina, negare: o trecho entre os versos 68 e 72, sobretudo do verso 69 ao 71, é uma espécie de torneio retórico de Gouveia, construído por meio de uma série de figuras, como litotes (ne nega), anáfora (negare), poliptoto (cupias, cuperes; nega, negare; uelim, uellem) e paralelismo (posses negare \& cuperes negare).

Uma sutileza especial recobre a paronomásia "uelim ac uellem": de acordo com Ernout, o uso do verbo uolo no subjuntivo, na primeira pessoa do singular, tem nuances especiais, seja presente (uelim), seja imperfeito (uellem). A diferença básica entre os dois tempos verbais, como subjuntivo de valor potencial e subjuntivo de valor irreal, se transfere para essas formas verbais específicas, concedendo a uelim um teor de optativo, exprimindo uma "afirmação atenuada" ou mesmo uma expressão atenuada de desejo (eu gostaria, je voudrais), ao passo que uellem, como irreal do presente, indica o arrependimento. ${ }^{236}$ Gouveia também foi hábil no uso da uariatio em relação à construção do complemento dos dois verbos: no caso de uelim, usa uma oração subordinada sem conectivo, enquanto que, no caso de uellem, emprega a conjunção $u t$ : note-se que as duas construções são usuais no latim clássico.

74 En alius rerum nascitur ordo mihi: esta formulação, em termos filosóficos, se assenta nas idéias estóicas, sobretudo na noção de destino como soberano, inexorável e providencial.

Em termos lingüísticos, porém, devemos procurar a fonte do verso em Virgílio, que encerra o verso 74, do livro VII, da Eneida, com o seguinte hemistíquio:

\section{(...) maior rerum mihi nascitur ordo.}

É curioso notar como Gouveia, ao falar de uma nova ordem de acontecimentos, salientada pelo pronome alius, também faz uma modificação na ordem das palavras do verso imitado, dando ao seu texto uma nova ordenação, se comparada ao original virgiliano. É de observar como o jogo vocabular é coerente com o sentido pretendido: a única substituição, efetivamente, se dá através da palavra alius (outro), que substitui maior, enquanto as demais são apenas deslocadas.

\footnotetext{
${ }^{236}$ Ernout, op. cit., pp. 239-241, § 258.
} 
79-80 Hem quid ego admisi? quae non ego numina demens, / Quos ego non colui demeruique Deos: convém justificar algumas opções de tradução: o verbo admitto, muitas vezes complementado por substantivos como scelus, fraus, inhonestum, etc, pode ser usado também intransitivamente, sempre com o sentido de cometer algum tipo tipo de crime; por isso, consideramos a idéia subentendida no pronome interrogativo. Numen significa "divindade, poder divino ou sobrenatural", mas pode, por metonímia, significar "desígnio divino, vontade divina"; como Gouveia já usou Deos no verso 80, e pelo que se depreende do contexto, pareceu-nos razoável a tradução proposta. Finalmente, em relação a demerui, verbo usado freqüentemente em conexão com deuses ou pessoas, como bem observou Zeeb ${ }^{237}$, não é fácil escolher o melhor termo do português para a tradução; a idéia é de "agradar, corresponder à vontade de outrem, atrair-lhe a simpatia por meio de favores, tratar com reverência ou de acordo com o esperado".

84 Ad lacrimas quamuis nil mala nostra tuas: o uso da preposição ad é extremamente rico e variado de significações, o que torna difícil e questionável qualquer opção de tradução, ainda mais numa frase sem verbo, como a que Gouveia formulou; entretanto, seguimos a interpretação de Zeeb, que lhe atribui, neste verso, uma noção comparativa ${ }^{238}$, traduzindo "although my misfortunes are nothing compared with yours tears" ${ }^{239}$. Em paráfrase, o fato de Catherine chorar representa o pior dos males para Gouveia.

Também acreditamos plausível que a noção de $a d$, neste verso, seja a de aproximação, ou, mais precisamente, a de objetivo, propósito ou intenção a se atingir; isto é, parafraseando o texto, Gouveia afirma que seus males provocariam as lágrimas de Catherine, ainda que essa não fosse de jeito nenhum a sua intenção; seus males não existem em função das lágrimas da amada, nem desejam provocá-las: ainda que isso seja inevitável, não é proposital. Neste segundo caso, a tradução do dístico poderia ser: "Sentirias minha dor, e verterias lágrimas, condoída, / Ainda que meus males não visem, em absoluto, a provocar tuas lágrimas”.

\footnotetext{
${ }^{237}$ Zeeb, op. cit., p. 55.

${ }^{238}$ Diz Zeeb, op. cit., p. 56: "in this connection ad means 'compared with'."

${ }^{239}$ Zeeb, op. cit., p. 57.
} 
92 fuerit: acolhemos a leitura de Zeeb ${ }^{240}$, que considera fuerit como futuro do pretérito (e não perfeito do subjuntivo), formando perífrase verbal com os gerundivos quaerenda e sollicitandus, com nuance de obrigação. Levamos em consideração o fato de que, a partir do verso 73, o trecho final da carta se volta para especulações acerca do futuro amoroso de Gouveia e Catherine, em função do afastamento de Gouveia. A partir desse verso, aliás, são freqüentes as formas verbais no futuro.

\section{Segunda Carta}

1 mollescere: outras traduções seriam admissíveis, desde a mais literal "amolecer", até "enternecer-te", "abrandar-te", "comover-te".

3 Lusisti: o sentido mais literal do verbo ludo, ludere, é "brincar com", "tratar de maneira leviana", "não levar a sério", mas abarca, num sentido conotativo, a noção de “enganar, iludir".

4 Res est plena leuis credulitatis amor: em relação a leuis, optamos pela tradução "imprudente", ao lado de outras possibilidades, como "irrefletida, inconseqüente, leviana"; na preferência por "imprudente", pesou a idéia, abrangida por esse adjetivo, de atitude pouco cautelosa, pois nos parece que a escolha de Gouveia tenha a ver não com uma incriminação da atitude de Catherine (longe disso!), mas com a idéia de que ela se entregou fielmente ao homem amado, um sentimento puro e crédulo, sem desconfianças ou prevenções. Talvez possamos pensar ainda em "iludível", seja pela aproximação entre leuis e o verbo lusisti, do verso anterior, seja pela oposição a grauis, que significa algo "sério", com que não se brinca.

5 Me mea simplicitas. culpae non plectimur ergo: trata-se de um dos versos mais complexos de Gouveia, estranho ao padrão clássico, e, conseqüentemente, difícil de abordar. Entretanto, discordamos inteiramente da análise formulada por Katherine Zeeb, que aponta, na base do verso, uma série de malabarismos retóricos, a fim de justificar sua leitura. Segundo essa estudiosa, o verso é composto por uma única oração, em que "mea simplicitas" é sujeito do verbo "plectimur", numa silepse de número, ou numa aposição ao sujeito "nos". Esse

\footnotetext{
${ }^{240}$ Zeeb, op. cit., p. 57.
} 
mesmo verbo, por sua vez, estaria sendo empregado na voz média, reflexiva, sendo "me" o objeto direto. Quanto a "ergo", seria não uma conjunção, mas uma preposição, a reger o genitivo "culpae": equivalente a causa ou gratia + genitivo, significaria "em conseqüência de, por causa de". Sua tradução final foi "I in my innocence do not blame myself on account of my fault". 241

Os problemas dessa análise são, a nosso ver: primeiro, ignorar a pontuação do texto original, que coloca um ponto final após a palavra simplicitas e divide o verso em duas orações; segundo, atribuir a voz média ao verbo plecto, sendo que não há nenhum registro dessa construção na literatura latina; ignorando, ademais, que esse mesmo verbo foi sempre construído na voz passiva, com o sentido de ser punido (to be punished), e não culpar (to blame); terceiro, admitir duas silepses contraditórias ao mesmo tempo, pois, segunda ela, o sujeito de plectimur é nos, ao passo que o objeto direto é me; forçando ainda o fato de que, nessa proposta, o sujeito expresso, "mea simplicitas", seria equivalente ao nos, sujeito oculto; ou seja, o verbo concorda com o sujeito oculto e não com o sujeito claro; quarto, ignorar que o verbo plecto, assim como outros verbos de punição ou condenação, pode ser acompanhado por complemento no genitivo de relação, indicando o crime, sem necessidade da partícula ergo; esta, por sinal, sempre vem, no uso clássico, logo a seguir ao termo regido, e nunca separada, como no verso gouveiano.

Nossa análise, antes de mais nada, respeita a pontuação feita por Gouveia, e admite a existência de duas orações no verso. Com efeito, isso torna o hemistíquio final, "culpae non plectimur ergo", muito simples de analisar: o verbo, no uso mais tipicamente clássico, está na voz passiva; o uso de nos por ego é absolutamente freqüente em Gouveia, por imitação da construção poética clássica; culpae é genitivo de relação, indicando o crime em função do qual ocorre a punição. Resta apenas nos determos na correta análise de ergo: se, como propõe Zeeb, é uma preposição (de emprego raro e específico no latim clássico), ou se seria a conjunção, geralmente consecutiva, de uso mais freqüente. Optamos por considerar o termo uma conjunção, com base tanto no sentido do contexto quanto no uso da palavra em Ovídio, que é o principal modelo das cartas gouveianas, pois o poeta usa a conjunção ergo 101 vezes, mas nos pareceu que nunca empregou ergo como preposição (nossa pesquisa não foi minuciosa, mas, a princípio, não registramos nenhuma utilização de ergo como preposição).

${ }^{241}$ Zeeb, op. cit., pp. 58-9. 
Entretanto, se consideramos resolvida a parte final do verso, resta ponderarmos como interpretar a parte inicial, mais difícil, formada por três palavras, sem verbo aparente, e que, em decorrência de nossa análise, constitui uma estrutura sintática independente: "me mea simplicitas". Pelo contexto, só conseguimos encontrar duas explicações razoáveis; a primeira explicação é bastante simples: ocorreria aqui zeugma, com a elipse do verbo "plectit" na primeira oração, explicitado (plectimur) na segunda. A tradução do verso seria, assim, "Minha candura é que me pune; não estou sendo punida em conseqüência de um defeito, portanto". Esta solução tem uma única, mas fundamental desvantagem: desconsiderar o fato de que o verbo "plecto", no latim clássico, nunca foi usado na voz ativa. A segunda explicação tem nossa preferência: consideramos essa frase um eco de construções clássicas semelhantes, e imaginamos que há um verbo subentendido ligando o sujeito mea simplicitas ao objeto direto me.

Há duas construções que nos permitimos apontar como as fontes mais prováveis da construção gouveiana: a mais é comparável, a nosso ver, é a frase "me mea fata trahebant", que surge, exatamente assim, nas Metamorfoses (VI, 816) e nos Tristia (II, 1, 341); a expressão foi citada no poema de abertura do volume publicado por Gouveia, em 1540, no poema introdutório Libellus lectori, no verso 15. Portanto, Gouveia tinha essa frase explicitamente armazenada em seu arsenal alusivo aquando da publicação das cartas. Cabe observar, ademais, que Ovídio, na verdade, faz a construção calcado em uma passagem de Propércio, que havia escrito "me mea fata trahentem" nas Elegias (IV, 9, 65). Sem entrar no mérito das múltiplas citações e alusões, cabe notar que a sombra dessa frase se aplica à perfeição ao contexto do verso em análise: ou seja, a persona Catherine afirma, no quinto verso de sua carta a Gouveia, que foi levada a agir daquela maneira, isto é, foi levada a confiar nele por causa de sua candura. Sua pureza de alma imaculada, sua ausência de malícia é que a levou a confiar em Gouveia e ser por ele enganada. A concisão do verso é possível graças à alusão subentendida, facilmente, a tais versos.

14 Quamque iterum uiolet, altera pacta fides: o valor do subjuntivo do verbo uiolet é questionável: segundo nosso entendimento, trata-se de um optativo ("que ele viole"), mas é de considerar a interpretação de Zeeb, segundo a qual há nele uma nuance final, como se 
depreende de sua tradução: "and he has made another pledge of faith to violate a second time". 242

23-24 malim te uiuere, malim: / Tristior at morte uita sit illa tamen: embora isso não provoque grandes alterações na tradução ou no sentido geral dos versos, cabe salientar que há duas explicações possíveis para o subjuntivo do verbo sit, no verso 24: ou por subordinação ao verbo malim (na segunda ocorrência, como última palavra do verso 23), ou como subjuntivo optativo, independente do verso 24. Seguindo a análise de Zeeb, consideramos os versos gramaticalmente independentes, inclusive por respeito à pontuação original feita por Gouveia. Na outra hipótese, a tradução seria: "Prefiro que tu vivas, mas prefiro / que tua vida seja mais triste do que a morte".

35 Nil ubi non tuleris, leuior sit crimine culpa: segundo nosso entendimento, uma paráfrase do verso seria a de que, depois de sofrer tudo o que de pior pode acontecer, conforme os desejos de Catherine, então ele terá expiado uma parte de sua culpa, isto é, ao passar pelos castigos, ele terá ficado aliviado da culpa relacionada ao crime de perjúrio de que a amada o acusa. Enfim, ao pagar por seu crime, a culpa fica reduzida.

36 Pacatumque tibi confiteare Iouem: ao pé da letra, "que tu confesses que Júpiter foi pacificado por ti”, ou “que Júpiter já se encontra em paz contigo".

38 Imperiuratae aquae: trata-se de uma referência poética ao Estige, por cujas águas os deuses faziam seus juramentos mais solenes, impossíveis de quebrar. Como bem demonstrou $Z_{\text {Zee }}{ }^{243}$, o adjetivo imperiuratae é um hapax, pois, em toda a literatura latina antiga, só foi usado uma única vez, justamente por Ovídio, no verso 78 de Ibis. A reutilização consciente de Gouveia serve para evidenciar não apenas o forte vínculo do poema com Ovídio, mas a manifesta fonte desse trecho (e da segunda carta em geral).

49 Elissam: outro nome de Dido, abandonada por Enéias, aqui referido como "frígio fugitivo" (Phryx profugus).

\footnotetext{
${ }^{242}$ Zeeb, op. cit., pp. 60-1.

${ }^{243}$ Zeeb, op. cit., pp. 65-6.
} 
61 Consule: a tradução, "Preocupa-te em descobrir", é um pouco artificial, e distanciase de uma tradução mais literal, que, a nosso ver, seria simplesmente "descobre", ou mais precisamente, “investiga, procura saber, pergunta". Nossa intenção foi reforçar a coesão vocabular entre este verso e o 63, que começa com o mesmo verbo, embora no indicativo.

$\mathrm{Na}$ verdade, todo o trecho de dois dísticos, entre os versos 61 e 64, é vinculado pelo vocabulário escolhido, que gira em torno de uma idéia básica, a de preocupação pela cura, pelo cuidado ou pelo conforto da outra pessoa. Mas, ao mesmo tempo, Gouveia se aproveita da plurivocidade dos termos escolhidos reforçar a invectiva ou a ironia desdenhosa de Catherine.

Assim, a repetição de consule e consulis não é apenas um poliptoto gramatical, com a diferença entre imperativo e indicativo, mas também uma variação semântica, pois nos parece que, no primeiro uso, o sentido do verbo se aproxima da acepção de "perguntar a um especialista, pesquisar para tentar descobrir" (qual é o remédio de que a minha ferida necessita), emprego que está na origem do substantivo "consulta", em português (inclusive “consulta médica”, cuja aproximação nos é inevitável, dado o contexto). Já no segundo uso (consulis), o sentido do verbo se aproxima da acepção de "observar os interesses de, preocupar-se com, dedicar-se ou dar atenção a". Nesse sentido, a escolha da palavra cura, no verso 64, é exímia, pois esse termo multívoco concentra em si tanto a acepção de "cuidado ou dedicação", quanto a de "cura" (inclusive médica) e ainda a de "preocupação, ansiedade".

Como se vê, Gouveia teceu uma coesa rede vocabular, cuja tradução não é fácil; em todo o caso, procurou-se, ao traduzir, forçar uma identidade entre tais palavras, a partir da noção de "preocupação", ainda que sob o risco de redução da polivalência observável no texto original.

63 Consulis expectem qui non rediturus abisti: discordamos da análise de Zeeb, que coloca consulis como verbo subordinado a expectem, e traduz "Should I expect you to take thought, you who went away with no intentions of returning". Com efeito, parece-nos gramaticalmente insustentável que consulis, no presente do indicativo, seja subordinado a um verbo no subjuntivo. Além disso, a análise de Zeeb é incoerente com sua perfeita identificação da fonte deste verso gouveiano no seguinte verso de Ovídio (Heroides, II, 99):

Expectem qui me numquam uisurus abisti? 
De fato, o verbo expecto tem, como complemento mais freqüente, uma oração interrogativa indireta, iniciada por pronome relativo com função interrogativa, exatamente como faz Gouveia, em sua imitação de Ovídio.

Além disso, o verbo consulo admite a regência de uma oração subordinada substantiva iniciada por $u t$. É sabido que a sintaxe latina admite a elipse da conjunção e a sobreposição assindética das duas orações.

Portanto, nossa conclusão é a de que expectem inicia uma oração subordinada a consulis. Quanto ao valor semântico de consulis, remetemos para o comentário acima.

72 Secura: entenda-se "livre dessas preocupações", isto é, dos anseios expressos anteriormente.

\section{Terceira Carta}

1-2 EXPECTAS tibi dum mittam, Catharina, salutem? / Hei mihi, quo careat mittere nemo potest: percebe-se um intencional duplo sentido no emprego da palavra salutem, no primeiro verso da carta, pois o substantivo significa tanto "saudação, cumprimento" (sendo o termo convencional de abertura das cartas) quanto "saúde, bem-estar, felicidade, salvação". O trocadilho de Gouveia se baseia em construções equivalentes de Ovídio, que, aliás, faz uma elaboração especial do ato de cumprimentar, em circunlóquio, em diversas composições das Heróides (vejam-se as aberturas das epistulae 13, 16, 18 e 19) e das Pônticas. Mas o dístico inicial da terceira carta de Gouveia se baseia, particularmente, no incipit de três diferentes poemas, a saber:

Em Heroides, IV, 1-2:

Quam nisi tu dederis, caritura est ipsa, salutem mittit Amazonio Cressa puella viro.

Em Tristia, V, 13, 1-2:

Hanc tuus e Getico mittit tibi Naso salutem, 
mittere si quisquam, quo caret ipse, potest.

Em Epistulae ex Ponto, I, 10, 1-2:

Naso suo profugus mittit tibi, Flacce, salutem, mittere rem si quis qua caret ipse potest.

6 Ipse tuus, domina tu mihi nuper eras: discordamos inteiramente de Zeeb, que entende que, no primeiro hemistíquio, está subentendida a palavra dominus, e interpreta domina como simples forma afetuosa de tratamento, traduzindo-a por "sweetheart". Nesse sentido, ela vê a relação entre Gouveia e Catherine como sendo de igual para igual.

Muito ao contrário, Gouveia inicia no sexto verso um longo trecho construído sobre o topos do amor que escraviza: o homem que ama é um escravo a serviço de sua senhora ou dona. No verso 16, o poeta explicita esse entendimento ("tu domina ... seruus ego"), que repercute muito além, ao longo do poema, como, por exemplo, no verso 25, na pergunta "dominam, fugitiue, relinques".

Portanto, se há algum termo subentendido, ele só poderia ser "seruus", jamais "dominus".

7 libertatis: mais um problema de interpretação de Zeeb, decorrente de sua leitura equivocada da relação estabelecida pelo poeta entre os dois amantes. Segundo essa estudiosa, deve-se subentender, neste verso, a liberdade de chamá-la de "domina", isto é, a liberdade de chamá-la de "meu amor". Por isso, Zeeb traduz o verso da seguinte maneira: "And I did not demand caressing kisses as the reward of this privilege". Sua paráfrase não dá margem a dúvidas: "Merely because we were dominus and domina to each other and I was free to call you 'sweetheart', I did not expect and exact from you the usual tokens of love".

Nosso entendimento é muito diferente. Do ponto de vista da tópica do amor como escravidão, compreendemos que libertatis não é a liberdade de poder chamá-la de forma afetuosa, mas a libertação do seu papel de escravo na relação; bem de acordo com esse topos, a escravidão é algo desejável; portanto, a liberdade é um castigo, nunca uma recompensa: a liberdade é o preço a pagar diante de alguma atitude indecorosa, que determine o fim da relação. 
Parafraseando o texto: Gouveia diz que há pouco era escravo de Catherine, por amor, mas que já não é mais; indignado pelo fim dessa doce escravidão, afirma que o preço dessa recente liberdade não pode ter sido o fato de exigir beijos da mulher amada, pois sempre fora um homem respeitoso, ou seja, a liberdade não foi decorrente de avançar os limites do decoro, não foi dessa maneira que ele a "comprou" ou a obteve.

8 uix tanti uita putanda fuit: uma tradução alternativa, talvez mais literal, seria: "Dificilmente minha vida devia ser considerada de tão alto valor".

11 nobilitas: embora tenhamos preferido traduzir o termo por "nobreza", cabe ter em mente a referência aos usos anteriores do vocábulo nesta obra, anteriormente traduzida por "fama", "bom nome”, "boa reputação".

12 arbitrii iura tulere mei: uma das acepções de arbitrium, conforme formulada pelo OLD, parece aplicar-se perfeitamente ao verso gouveiano: "Wishes, desires, etc ... esp. with regard to procedure or pollicy". Com efeito, podemos dizer, em paráfrase, que os fatores anteriormente citados estabeleceram ou impuseram as regras, leis ou limites (iura) dos desejos e da conduta de Gouveia em relação a Catherine.

17 neque me facis ipsa tuorum: facis, aqui, tem o sentido de "considerar", "enxergar como", "tratar como". O uso reiterado do pronome possessivo tuus, como neste verso, reforça o vínculo de submissão de Gouveia sob o jugo de Catherine e a idéia de propriedade escrava que ele representa para ela.

20 Cur non ingenii sum, Catharina, tui: a pergunta, em tom indignado, procura rebater a acusação feita por Catherine; ela afirmou que ele, em pouco tempo, deixou de amá-la; ele retruca dando a entender que, se isso fosse verdade, ela em nada seria diferente dele, pois também ela o terá esquecido rapidamente. Assim, eles são semelhantes em caráter ou temperamento (ingenium). Nesse sentido, uma outra formulação da pergunta, em paráfrase, seria: "Em que meu temperamento é diferente do teu?" ou "Por que não sou igual a ti em caráter?". 
26 Haeccine mentiti finis amoris erat: Zeeb acompanha a edição de Van Vaassen, que substitui "erat" por "erit". Por tal motivo, traduz "Was the love only feigned and will this be the end of it?". Mantivemos nossa leitura conforme o original gouveiano, entendendo que a pergunta carrega um tom indignado e irônico, semelhante ao uso de erat no verso 77 da primeira carta, cujo dístico (77-78) encerra uma interrogação de teor semelhante. Note-se que mentiti não atua, nesta oração, em perífrase verbal, mas apenas como adjetivo: "fingido, falso".

28 Dic, ubi nostra fides? dic, ubi noster amor: manteve-se a leitura feita ao longo da tradução, considerando os pronomes possessivos nostra e noster como plural poético. Embora se reconheça que neste caso seria inteiramente adequada a tradução literal ("nossa fidelidade, nosso amor"), considerou-se que a persona Catherine, dirigindo perguntas indignadas a Gouveia, estava questionando onde ficaria sua fidelidade e seu amor, o que ela faria deles, exigindo que seus sentimentos fossem levados em consideração.

35 facies indigna: essas duas palavras são muito importantes, pois estabelecem o parâmetro da argumentação que Gouveia apresentará nos próximos versos, e são aludidas algumas vezes na seqüência. De um lado, com facies Gouveia transmite a idéia de que sua situação problemática, na pobreza, é apenas superficial, aparente e transitório, em contraste com seus bens mais sólidos e profundos, como a erudição, o prestígio ou a nobreza da família. De outro lado, com indigna Gouveia sugere que essa situação é injusta, não merecida, pois não é conseqüência de seus atos, e não condiz com suas qualidades. Portanto, a nosso ver, o complemento implícito do adjetivo indigna não é Catherine, como propõe $Z^{2} e^{244}$ (isto é, a situação de Gouveia é indigna dela, donde o seu desprezo), mas sim Gouveia (isto é, a situação é injusta e indigna dele).

37-38 Despicienda tamen fortunae iniuria nostrae / Non uenit: as gramáticas de Allen e Ernout comentam o uso do gerundivo como complemento verbal para indicar finalidade, mas não incluem o verbo uenio na lista dos que são utilizados nessa construção. Uma hipótese alternativa, embora menos pertinente, seria considerar os gerundivos despicienda e dolenda como simples adjetivos construídos sobre seus respectivos verbos.

\footnotetext{
${ }^{244}$ Zeeb, op. cit., p. 77.
} 
De uma forma ou de outra, a tradução proposta é uma adaptação do vocabulário empregado por Gouveia. Assim, iniuria seria propriamente "injustiça", conforme, aliás, indica o contexto, pois no dístico anterior o poeta deixa claro que está pagando pelo crime que a sorte ou a fortuna cometeu. Quanto a isso, discordamos da análise de Zeeb, que considera fortunae como genitivo objetivo, afirmando, ainda, que se trata da injúria cometida contra a fortuna de Gouveia. Ora, todo o trecho deixa claro que a fortuna (ou sorte) é que cometeu uma injúria, isto é, uma injustiça (ou dano criminoso), da qual Gouveia é a vítima.

Quanto a uenit, suprimido na tradução, o sentido no trecho seria o de "vir" ou "existir"; ou seja, "a injustiça (ou o mal) vem (ou existe) não para ser desprezado, mas para ser lamentado".

47 quo recreor: o verbo recreo, na voz média ou reflexiva, significa "recobrar-se, restabelecer-se, sentir-se melhor", encerrando especialmente a idéia de recuperar-se diante de adversidades enfrentadas; nessa medida, o emprego aqui parece muito apropriado. Traduções alternativas de quo recreor poderiam ser "em conseqüência disso me restabeleço" ou "em virtude do que me sinto melhor"; ou seja, a sua saúde e a sua esperança de dias melhores é que ajudam Gouveia a ganhar novo fôlego para enfrentar os problemas.

51 hinc: a repetição anafórica de hinc, por três vezes, nos levou à tradução proposta, isto é, "de um lado ... de outro ... de outro ainda". Mas, diante do sentido próprio do termo, “a partir deste ponto", poderíamos pensar numa tradução que repetisse três vezes a expressão "a partir daí"; de fato, nos parece que a idéia de Gouveia é a de que, tendo atingido uma posição de extrema inferioridade na sociedade, é a partir disso (num sentido tanto temporal quanto espacial) que a pobreza, a vergonha e o amor lançam simultaneamente seus ataques contra o poeta.

57 tuorum: optamos por deixar o pronome possessivo desacompanhado, como no texto latino; no entanto, não deixamos de pressentir que este uso remete aos empregos anteriores, em que Gouveia afirma desejar ser escravo (amoroso) de Catherine.

61 amores: manteve-se o termo no plural, na tradução, ainda que seja cabível a suposição de se tratar de um plural poético, tão freqüente em Gouveia. 
64 amoris plena sagacis: sem contar a semelhança de construção com o verso 4, da segunda carta, há um eco, neste verso, não só pelo vocabulário como também pelo conteúdo, do verso 12 da primeira epístola das Heróides:

res est solliciti plena timoris amor.

70 Estque puto ad lacrimas uita relicta mihi: seguimos a análise de $Z^{2} b^{245}$, que considera mihi um dativo de interesse, complemento do verbo relinquo.

71 succedere: não há outra opção coerente com o contexto, senão a de atribuir a succedere seu valor original, etimológico, de "colocar-se sob", "pôr-se ao abrigo de", “esconder-se”, donde a noção de "ceder seu lugar", e não "suceder, tomar o lugar de".

76 It quoties longa tardior hora die: considerando a escansão do pentâmetro, a palavra longa teria o -a final longo e estaria concordando com die; não é de estranhar, uma vez que o substantivo dies, como feminino, é freqüentemente encontrado entre os clássicos, especialmente quando indica a passagem do tempo. Porém, cabe mencionar o argumento de $Z_{\text {Zeeb }}{ }^{246}$, que associa longa a hora, e considera que ocorreu, na métrica, uma abreviação da vogal final, antes da cesura, possibilidade registrada na poesia gouveiana, particularmente nessa posição do pentâmetro.

95 mulceor: é de notar que um dos sentidos conotativos do verbo mulceo é "adoçar"; dentro do espírito de trocadilhos do dístico, em lugar da tradução "eu encontro conforto em meus próprios males”, poderíamos propor: “eu me adoço com meus próprios males”.

\section{Quarta Carta}

23 fatorum immobilis ordo: além da alusão intratextual, ao verso 74 da primeira carta, e da sua relação, portanto, com a filosofia estóica e com o texto virgiliano, podemos observar

\footnotetext{
${ }^{245}$ Zeeb, op. cit., p. 79.

${ }^{246}$ Zeeb, op,. cit., pp. 80-81.
} 
uma alusão mais direta ao verso da Eneida V, 707, que termina com as palavras "fatorum posceret ordo".

25 fer et obdura: é nítido o eco da expressão "perfer et obdura", que se encontra inicialmente em Catulo, no poema 8, sendo depois imitada três vezes por Ovídio, nos Amores, na Ars e nos Tristia.

37 bene semper amaui: o advérbio bene permite, aqui, uma dupla interpretação: tanto pode indicar moralidade, isto é, "amei honestamente, virtuosamente", quanto intensidade, isto é, "amei inteiramente, completamente".

44 fidem: este termo, mesmo na especificidade da linguagem jurídica (imitada por Gouveia neste trecho), é polissêmico. Aqui, acreditamos que se refira à credibilidade que se deve atribuir a Gouveia, em função das "provas" a seu favor que ele pode invocar em sua defesa no imaginário "processo" movido para vencer a afeição de Catherine. Em outras palavras, fides designaria o "crédito", as "credenciais" ou a "boa impressão" despertada por Gouveia.

49 Id sat erit misero, nec amari poscimus abs te: o pronome $i d$, que inicia o verso, tem certo grau de ambigüidade, pois tanto pode referir-se ao verso anterior, isto é, à oração "nolis immemor esse mei”, quanto ao verso seguinte, ou seja, “Oderis, ast odii caussa sit unus amor". Com efeito, embora esse pronome retome, mais comumente, elementos do contexto anterior, numa função anafórica, também pode ter função catafórica, antecipando elementos que vêm a seguir, conforme descrição feita por Ernout ou pelo OLD.

52 Spiritus inuisas dum trahet iste moras: Concordamos com Martha Zeeb, que considera que, neste verso, iste se refere à primeira pessoa, e traduz "spiritus ... iste" por "esta minha vida". Embora ela não faça comentários sobre sua opção, pensamos que tal escolha repouse em pelo menos três justificativas: primeiro, a possibilidade gramatical de tal fenômeno, apontada por Ernout e pelo OLD, existente mesmo entre os clássicos, de que é prova o sintagma "iste meus stupor", do verso 21, poema 17, de Catulo; segundo, o fato de que spiritus significa sobretudo "espírito vital", "sopro de vida", idéias que, no trecho, só cabem se aplicadas ao eu-poético; terceiro, o fato de que este verso, na verdade, faz uma 
alusão e reelaboração das seguintes palavras do epigrama II, 12, de 1539, republicado, com alterações, como epigrama 70, em 1540: "inuisas me trahere usque moras". Naquele contexto, essas palavras indicam precisamente a indesejada continuidade da vida, numa visão neoplatônica e petrarquista do corpo como uma prisão da alma, em que a vida é um castigo a ser cumprido.

Por esses três fatores e por todo o contexto, em que o dístico, mais uma vez, tende a enfeixar uma idéia própria, parece-nos correta a interpretação de iste como "este meu".

59-60 merito sine gratia crescit / Virtutique patet latior ara tuae: seguimos a interpretação de Martha Zeeb, que atribui uma função causal ao sintagma "merito sine" e considera que gratia se refere à bondade, capacidade de perdoar e demonstração de boavontade de Catherine, que ama Gouveia mesmo que ele não mereça. A seguir, a estudiosa norte-americana interpreta o verso 60 como uma retribuição de Gouveia, que, diante da bondade de Catherine, a endeusa num altar que celebra a sua excelência moral: segundo Zeeb, o altar (ara) é metáfora da produção poética de Gouveia, que se amplia (patet latior) na medida em que ele é aceito e perdoado por ela.

93 Vidit Abydenum iactatum Sestias undis: Gouveia usa dois adjetivos toponímicos como epítetos para referir-se ao mito de Leandro e Hero. Assim, Abydenum é "o abdeno", ou seja, o jovem morador de Abdeno, Leandro; Sestias é "a séstia", ou seja, a donzela de Sesto, Hero. Como os adjetivos toponímicos não se encontram registrados em dicionários da língua portuguesa, e o desdobramento de ambos deixaria o verso muito longo e repetitivo, optou-se por nomear Hero e usar o epíteto “jovem de Abdeno" para Leandro.

97 Heroidas: a tradução mais corrente para o português seria "heroínas", mas preferiuse manter "Heróides" porque se percebe claramente que Gouveia está se referindo às heroínas cantadas nos poemas da obra Heróides, de Ovídio. A alusão é ainda mais evidente pelo fato de Gouveia optar pelo uso da palavra grega, grafada com inicial maiúscula. 


\section{CONCLUSÃO}

Acreditamos que as análises poéticas efetuadas ao longo da presente tese ajudaram a descortinar um autor interessante e com perícia fora do comum no manejo de procedimentos alusivos e no domínio de instrumentos e recursos literários. Procuramos apontar as melhores qualidades artísticas de um autor erudito e versátil, que compôs versos em dois gêneros de poesia (de feição clássica) completamente diferentes, mostrando à comunidade literária (a Respublica Litteraria) sua capacidade de escrever, em pleno Quinhentos, segundo a mais perfeita expressão clássica latina.

Ao recordar o percurso acadêmico no trato da obra de Antônio de Gouveia, lembramos que, de início, nossa intenção era estudar apenas sua obra elegíaca das cartas de amor. Só posteriormente, com a perspectiva de obtenção de apoio para um período de pesquisas em Portugal, é que acrescentamos o exame da poesia epigramática.

Se esse acréscimo multiplicou o trabalho a ser feito, também rendeu variados frutos. De fato, conseguimos concluir a primeira edição e tradução integrais, com aparato crítico, da obra completa, publicada em vida, de Antônio de Gouveia; trata-se, aliás, da primeira pesquisa do gênero em nível internacional. Ademais, ao abranger as duas edições de epigramas, publicadas em 1539 e 1540, pudemos corrigir equívocos de interpretação do texto cometidos por outros estudiosos, que se haviam dedicado sempre a abordagens parciais da obra. Essa inclusão também permitiu estudar os critérios estilísticos das alterações realizadas por Antônio de Gouveia, de forma a nos aproximarmos do seu processo de composição e de detalhes que influenciaram nas escolhas do poeta, perscrutando intenções literárias de outro modo inacessíveis.

Além disso, as referidas análises procuraram indicar um viés de abordagem da obra gouveiana, extensivo à literatura novilatina, que privilegia a investigação das relações intertextuais motivadas pela arte alusiva dos autores renascentistas.

Mas a análise poética vai além do âmbito restrito da literatura neolatina, propiciando um olhar renovado e aguçado na direção das obras da Antigüidade clássica, em virtude do exame do diálogo intertextual proposto pelos autores renascentistas, o qual dinamiza a literatura canônica e produz efeitos de sentido que se aplicam não somente às obras modernas, mas também às obras imitadas. Por isso, este trabalho, que se valeu de ferramentas de 
interpretação e de análise que têm sido empregadas no campo dos Estudos Clássicos (por autores como Stephen Hinds e Gian Biagio Conte), também pôde dar contribuições, assim pensamos, voltadas a essa área do conhecimento.

Em suma, como já foi dito, podemos apresentar, dentre os resultados alcançados pela presente pesquisa, em primeiro lugar, de forma inédita, a edição crítica do texto latino e a tradução (acompanhada de notas e comentários) da obra poética neolatina do humanista português Antônio de Gouveia, composta por cerca de duzentos epigramas e quatro cartas elegíacas; em segundo lugar, uma análise literária, também inédita, da obra poética desse autor renascentista lusitano, enfocando sobretudo as relações intertextuais entre sua poesia e o cânone clássico, ou seja, examinando a presença da literatura clássica em suas composições. 


\section{BIBLIOGRAFIA}

A) Obras literárias latinas ou neolatinas:

I) Obras de Antônio de Gouveia:

GOUVEIA, Antônio de. Antonii Goueani Lusitani Epigrammaton Libri Duo. Lugdunum (Lyon), 1539.

Antonii Goueani Epigrammata. Eiusdem Epistolae Quatuor.

Lugdunum (Lyon), 1540.

Antonii Goveani Iurisconsulti Clarissimi Opera. Lyon

(Lugduni), Ex Officina Vicentii, 1599.

Em Prol de Aristóteles. Tradução e prefácio de Aquilino

Ribeiro. Lisboa: Bertrand, 1940.

REYS, Antônio dos. Corpus Illustrium Poetarum Lusitanorum qui latine scripserunt. Lisboa: s.e., 1748.

SANTOS, Maria Luísa Meireles. Antônio de Gouveia: epigramas: livros I, II. Coimbra: Faculdade de Letras, Universidade de Coimbra, 1992. (Dissertação de mestrado).

VÁRIOS AUTORES. Flores Epigrammatum ex optimis quibusque authoribus excerpti per Leodegarium a Quercu. Tomus Primus. Paris, 1555. Tomus Secundus (Farrago Poematum). Paris, 1560. 
II) Obras de autores da época clássica:

AUSÔNIO. Ausonii Burdigalensis, uiri consularis, Omnia (quae adhuc in ueteribus bibliothecis inueniri potuerunt) Opera. Bordeaux (Burdigalae), Simon Millange, 1604.

BURMANN JR., Peter. Anthologia Veterum Latinorum Epigrammatum et Poematum, Tomo I. Amsterdam, 1759.

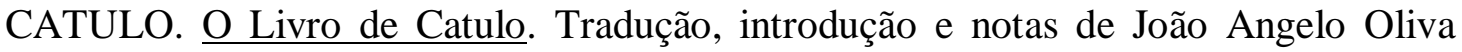
Neto. São Paulo: Edusp, 1996.

GONÇALVES, Simone Ligabo. As Heróides de Ovídio: uma tradução integral. São Paulo: FFLCH/USP, 1998. (Dissertação de Mestrado).

LIPSE, Juste. Inscriptionum Antiquarum quae passim per Europam liber. Accessit auctarium Iusto Lipsio. Franciscus Raphelengius, 1588.

OVÍDIO. Heroides. Amores. Loeb Classical Library. Cambridge, MA: Harvard University Press, 1986.

- As Metamorfoses. Tradução de David Jardim Júnior. Rio de Janeiro: Ediouro, 1985.

. Poemas da Carne e do Exílio. Seleção, tradução, introdução e notas de José Paulo Paes. São Paulo: Companhia das Letras, 1997.

. Os Remédios do Amor. Os Cosméticos para o Rosto da Mulher. Tradução, introdução e notas de Antônio da Silveira Mendonça. São Paulo: Nova Alexandria, 1994.

. The Art of Love and Other Poems. Loeb Classical Library. Cambridge, MA: Harvard University Press, 1985.

- Tristia. Ex Ponto. Loeb Classical Library. Cambridge, MA: Harvard University Press, 1988.

SMET, Martin. Inscriptionum antiquarum. S.e., s.d.

TERÊNCIO. P. Terentius Afer. Venetiae (Veneza), 1586. Pub. Terentii Aphri Comodiae Sex. Lyon (Lugduni), Sébastien Gryphe, 1553.

- Publii Terentii Comoedie Sex. Veneza (Venetiis), Brandinus et Octovianus Scotus, 1540. 
Pub. Terentii Aphri Comoediae Sex. Ab Antonio Goueano integritati suae restitutae. Lyon (Lugduni), Sébastien Gryphe (Sebastianus Gryphius), 1541.

VIRGÍLIO. Pub. Vergilii Maronis Opera. Per Antonium Goueanum castigata. Lyon (Lugduni), Sébastien Gryphe (Apud Seb. Gryphium), 1544. 
III) Obras de autores da época renascentista:

BERGOUNIOUX, Louis-Alexandre. Hugues Salel de Cazals-en-Quercy (1504-1553): un précurseur de La Pléiade. Oeuvres Poétiques. Genebra, Slatkine, 1969.

BOISSARD, Jean Jacques. Poemata. Epigrammatum, Elegiarum, Epistolarum libri.

BOURBON, Nicolas. Nicolai Borbonii Nugae. Paris, Michael Vascosanus, 1533.

BUCHANAN, George. Georgii Buchanani Scoti Elegiarum Liber I, Sylvarum Liber I,

Endecasyllabon Liber I. Eiusdem Buchanani Tragoedia, quae inscribitur Baptistes, siue Calumnia. Paris (lutetiae), Apud Mamertum Patissonium, in officina Roberti Stephani, 1579.

CARDOSO, José. Diogo de Teive: Comentário da Gesta Portuguesa. Braga: APPACDM, 2002.

DOLET, Étienne. Formulae Latinarum Locutionum Illustriorum Stephano Doleto

Gallo Aurelio Autore. Lyon (Lugduni), Apud Eundem Doletum. 1539.

Genethliacum Claudii Doleti, Atephani Doleti Filii. Lyon (Lugduni), Apud Eundem Doletum. 1539.

DU BELLAY, Joachim. Oeuvres completes. Paris, Honoré Champion, 2003.

DUCHER, Gilbert. Gilberti Ducherii Vultonis Aquapersani Epigrammaton Libri Duo. Lyon (Lugduni), Apud Seb. Gryphium (Sébastien Gryphe), 1536.

LORIOT, Pierre. Petri Lorioti Salinensis, De iuris apicibus Tractatus VIII. Lyon (Lugduni), Sébastien Gryphe, 1545.

MARULLUS. Epigrammata et hymni. S.e., s.d.

SAINCT-GELAYS, Melin. Oeuvres Completes. (Org. Prosper Blanchemain). Paris, Plon, 1873 (Reedição facsimilar: Liechtenstein, Kraus, 1970)

SALEL, Hugues. Oeuvres Poétiques Complètes. (Org. Howard Kalwies). Genebra, Droz, 1987.

SALMON (Macrin), Jean. Salmonii Macrini Iuliodenensis Lyricorum Libri Duo et Epithalamiorum Liber Unus. Paris, Gerardi Morrhii Campensis, 1531.

SCALIGER. Nouorum epigrammatum. S.e., s.d.

SíCUlO, Cataldo Parísio. Duas Orações. Coimbra: Centro de Estudos Clássicos e Humanísticos, 1974.

Coimbra, 1988.

Epistolae et Orationes. Coimbra: Universidade de 
SUSSANNEAU, Hubert. Dictionarum Ciceronianum Authore Huberto Sussanaeo Suessionensi. Paris, Apud Simonem Colinaeum, 1536.

- Epigrammatum H. Sussannaei Liber. Paris, Apud

Simonem Colinaeum, 1536.

. Huberti Sussanaei Legum et Medicinae Doctoris Ludorum

libri nunc recens conditi atque aediti. Paris (Parisiis), Apud Simonem

Collinaeum, 1538.

Enodatio aliquot uocabulorum, quae in aliis dictionariis

non reperiuntur, aut si forte paucula, aliter explicantur. Ex colletaneis P. H.

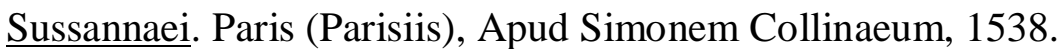

VÁRIOS AUTORES. Sales epigrammatum. S.e., s.d.

Epigrammatum graecorum. S.e., s.d.

VISAGIER, Jean. Ioannis Vulteii Rhemensis Epigrammatum Libri IIII. Eiusdem

Xenia. Paris, Apud Michaelem Parmanterium, 1537.

Ioannis Vulteii Rhemi Inscriptionum Libri Duo. Paris, Apud

Simonem Collinaeum, 1538.

- Ioannis Vulteii Rhemi Xeniorum Liber. Paris, Apud Simonem

Collinaeum, 1538.

Ioannis Vulteii Rhemensis Hendecasyllaborum Libri Quatuor.

Paris, Apud Simonem Collinaeum, 1538.

Ioannis Vulteii Rhemensis Ad Poetas Gallicos Libri Duo. Paris, Apud Simonem Collinaeum, 1538. 
B) Obras teóricas e analíticas:

ACHCAR, Francisco. Lírica e Lugar-Comum. São Paulo: Edusp, 1992.

BATAILLON, Marcel. Études sur le Portugal au temps de l'humanisme. Coimbra: Universidade de Coimbra, 1952.

BERGER, Ernst. Stylistique Latine. Paris: Klincksieck, 1942.

BERNARDES, José Augusto Cardoso. História Crítica da Literatura Portuguesa; volume II: Humanismo e Renascimento. Organização da coleção: Carlos Reis. Lisboa: Verbo, 1999.

BONARDI, Carlo. Lo Studio Generale a Mondovì (1560-1566). Torino, Fratelli Bocca, 1895.

BRAGA, Teófilo. História da Literatura Portuguesa: Vol. II - Renascença. Lisboa: INCM, 2005.

CAILLEMER, E. "Étude sur Antoine de Govéa". In Mémoires de l'Académie Impériale des Sciences, Arts et Belles-Lettres de Caen, 1865.

CAIRNS, Francis. Generic Composition in Roman and Greek Poetry. Edinburgh: EUP, 1972.

CARVALHO, Joaquim. Antônio de Gouveia e o aristotelismo da renascença. Coimbra: F. França Amado, 1916. (Tese de Doutoramento).

Estudos sobre a Cultura Portuguesa do século XVI. Coimbra: Universidade de Coimbra, 1947.

CHEVROU, Gaston (org.) À la Mémoire du Saintongeais Élie Vinet. Barbezieux, Ed. Emile Venthenat, 1910.

CONGRESSO INTERNACIONAL DO HUMANISMO PORTUGUÊS. Lisboa: Centro de Estudos Clássicos, 2002.

CONTE, Gian Biagio. Generi e Lettori. Milão: Arnoldo Mondadori, 1991. . The Rhetoric of Imitation. Genre and Poetic Memory in Virgil and Other Latin Poets. Ithaca and London: Cornell University Press, 1996.

COSTA, Jorgete C. da Conc. G. Subsídios para o estudo de António de Gouveia e da sua obra. Lisboa: Faculdade de Letras da Universidade de Lisboa, 1944. (Dissertação de Licenciatura)

CRUSIUS, Federico. Iniciación em la Métrica Latina. Barcelona, Bosch, 1987. 
DEZEIMERIS, Reinhold. De la Renaissance des Lettres a Bordeaux au XVIe Siècle. Genebra, Slatkine, 1970.

HARDIE, Philip (org.). The Cambridge Companion to Ovid. Cambridge: CUP, 2002.

HARTLEY, David. A Critical Edition of the Circumstantial Verses of Joachim Du Bellay. Lewiston, Ed. Edwin Mellen, 2000.

HINDS, Stephen. Allusion and Intertext. Dynamics of appropriation in Roman poetry. Cambridge: CUP, 2003.

HUMANISMO PORTUGUÊS NA ÉPOCA DOS DESCOBRIMENTOS (Congresso Internacional). Coimbra: Universidade de Coimbra, 1993.

HUTCHINSON, G.O. Hellenistic Poetry. Oxford: OUP, 1990.

KRISTELLER, Paul. Tradição Clássica e Pensamento do Renascimento. Lisboa: Edições 70, 1995.

LAURENS, Pierre. L'abeille dans l'ambre. Paris, Les Belles-Lettres, 1989.

LAUSBERG, Heinrich. Elementos de Retórica Literária. Lisboa: Fundação Calouste Gulbenkian, 1993.

MAROUZEAU, J. Traité de Stylistique. Paris: Les Belles Lettres, 1935.

MARQUES, A. H. Oliveira. Portugal na crise dos séculos XIV e XV. (Coleção Nova História de Portugal, direção de Joel Serrão e A. H. de Oliveira Marques). Lisboa: Presença, 1987.

MARTINS, José Vitorino Pina. Sobre o conceito de Humanismo e alguns aspectos histórico-doutrinários da cultura renascentista. Paris: Fundação Calouste Gulbenkian, 1970.

MATOS, Luís. Sobre António de Gouveia e a sua obra. Separata do Boletim Internacional de Bibliografia Luso-Brasileira, volume VII, número 4. Lisboa: Fundação Calouste Gulbenkian, 1966. Les Portugais en France au XVIe siècle. Coimbra: UC, 1952.

MUGNIER, François. Antoine Govéan, Professeur de Droit: sa famille, son biographe Etienne Catini. (Extrait du Tome XL (XVe de la 2e série) des Mémoires de la Société savoisienne d'histoire et d'archéologie). Paris, H. Champion, 1901. MUHANA, Adma. A Epopéia em Prosa Seiscentista. São Paulo: Unesp, 1997. MURARASU, D. La poésie néolatine et la renaissance des lettres antiques en France (1500-1549). Paris, J. Gamber, 1926.

OLIVEIRA MARTINS. História de Portugal. Lisboa: Guimarães, 1972 (16 edição). 
PICOT, Émile. Les Italiens en france au xvie Siècle. Bordeaux, Feret, 1901.

PIGHI, Giovanni Battista. I ritmi e i metri della poesia latina. Brescia, La Scuola, 1958.

PRATA, Patricia. $\underline{\mathrm{O} \text { caráter alusivo dos Tristes de Ovídio: uma leitura intertextual do }}$ livro I. Campinas: IEL/Unicamp, 2002 (Dissertação de mestrado).

QUICHERAT, J. Histoire de Sainte-Barbe: collège, communauté, institution. Paris, Hachette, 1860.

RAMALHO, Américo C. Estudos sobre o Século XVI. Lisboa: Imprensa Nacional, 1983.

ROY, Emile. "Lettre d'un bourguignon contemporaine de la 'Deffence et illustration de la langue françoise'", in Revue d'histoiere littéraire de la France. Paris, Armand Colin, 1895.

RUFFINI, Francesco. "L’Università di Torino: profilo storico”. In Annuario della Regia Università di Torino, 1899-1900. Torino, Stamperia Reale, Gennaio 1900.

SÁEZ, Rosa Ma. Marina. La Métrica de los epigramas de Marcial. Zaragoza, Institución Fernando el Catolico, 1998.

SARAIVA, António José. O Humanismo em Portugal. Lisboa: Jornal do Foro, 1956. Iniciação à Literatura Portuguesa. São àulo: Companhia das Letras, 2001.

SARAIVA, José Hermano. História de Portugal. Lisboa: Alfa, 1993.

SERRÃO, Joaquim Veríssimo. Antônio de Gouveia e o seu tempo (1510-1566). Separata do Boletim da Faculdade de Direito, volume XLII. Coimbra: Universidade de Coimbra, 1966.

TRENK, Wilma Aparecida. Discurso em defesa de Árquias (Pro Archia) e a humanitas de Cícero. São Paulo: FFLCH/USP, 1997. (Dissertação de Mestrado)

VALLAURI, Tommaso. Storia delle Università degli Studi del Piemonte. Torino, Stamperia Reale, 1845.

VASCONCELLOS, Paulo Sérgio. Efeitos intertextuais na Eneida de Virgílio. São Paulo: Humanitas, 2001.

WEST, David \& WOODMAN, Tony. Creative Imitation and Latin Literature. Cambridge: Cambridge University Press, 1979.

WILLIAMS, Gordon. Tradition and originality in Roman Poetry. Oxford: Clarendon Press, 1985. 
WINBOLT, S.E. Latin Hexameter Verse. Londres, Methuen, 1903. 
C) Obras de referência (gramáticas, dicionários, bibliografias, etc):

ALLEN, J.H. \& GREENOUGH, J.B. New Latin Grammar. Boston: Ginn and Company, 1931.

BIBLOS: Enciclopédia VERBO das Literaturas de Língua Portuguesa. Lisboa: Verbo, 1997.

CAPPELLI, Adriano. Dizionario di abbreviature latine ed italiane. Milão: Ulrico Hoepli, 1929.

CRETELLA Jr., José. Dicionário Latino-Português. $3^{\text {a }}$ edição. São Paulo: Companhia Editora Nacional, 1953.

FARIA, Ernesto. Dicionário Escolar Latino-Português. 5 $5^{\text {a }}$ edição. Rio de Janeiro: MEC/FENAME, 1975.

GAFFIOT, F. Dictionnaire Latin Français. Paris: Hachette, 1991.

GLARE, P.G.W. Oxford Latin Dictionary. Oxford: OUP, 1996.

HORNBLOWER, Simon \& SPAWFORTH, Antony. The Oxford Classical Dictionary. Oxford: OUP, 1996.

HOVEN, René. Lexique de la prose latine de la Renaissance. Leiden: Brill, 1994.

LEWIS \& SHORT. Latin Dictionary. Oxford: Clarendon Press, 1984.

LIDDELL-SCOTT. Greek-English Lexicon. Chicago: Follet, 1941.

LISBOA, Eugénio (coord.) Dicionário Cronológico de Autores Portugueses. MiraSintra: Publicações Europa-América, 1991.

MARTINS, Isaltina das Dores Figueiredo. Bibliografia do Humanismo em Portugal no século XVI. Coimbra: Instituto Nacional de Investigação Científica, 1986.

MOISÉS, Massaud. Dicionário de Termos Literários. São Paulo: Cultrix, 1997.

NIERMEYER, J.F. Mediae Latinitatis Lexicon Minus. Leiden: Brill, 1997.

NUNES, T. Borges. Abreviaturas Paleográficas Portuguesas. Lisboa: s.e., 1980.

RIEMANN. Syntaxe Latine. Paris: Klincksieck, 1935.

SARAIVA, F.R.S. Dicionário Latino -Português. Rio de Janeiro: Garnier, s.d.

SIDWELL, Keith. Reading Medieval Latin. Cambridge: CUP, 1997.

SOUTER, A. A Glossary of Later Latin. Oxford: Clarendon Press, 1957.

STELTEN, Leo. Dictionary of Ecclesiastical Latin. Peabody, MA: Hendrickson, 1995. 